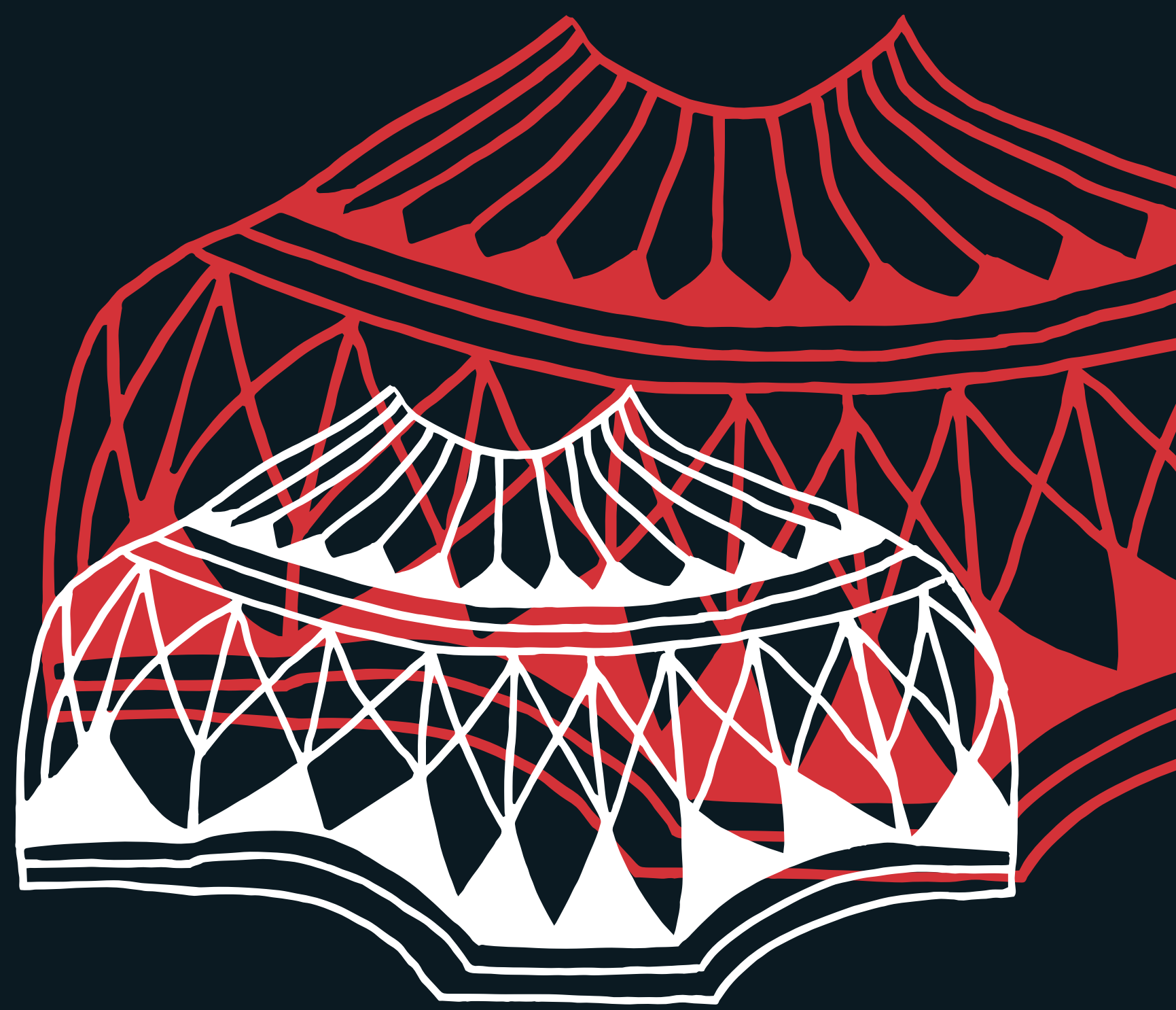

A Cosmopolítica da Gestação, do Parto e do Pós-Parto: autoatenção e medicalização entre os indios Munduruku 


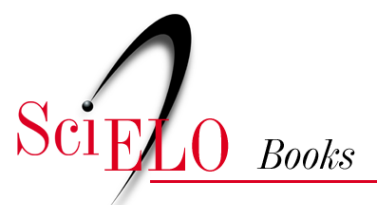

\title{
A Cosmopolítica da gestação, do parto e do pós-parto autoatenção e medicalização entre os índios Munduruku
}

\author{
Raquel Paiva Dias-Scopel
}

\section{SciELO Books / SciELO Livros / SciELO Libros}

DIAS-SCOPEL, R.P. A Cosmopolítica da gestação, do parto e do pós-parto: autoatenção e medicalização entre os índios Munduruku [online]. 2nd ed. rev. Rio de Janeiro: Editora FIOCRUZ, 2018, 210 p. Saúde dos Povos Indígenas collection. ISBN: 978-65-5708-014-6. https://doi.org/10.7476/9786557080146.

\section{International license.}

Todo o conteúdo deste trabalho, exceto quando houver ressalva, é publicado sob a licença Creative Commons Atribição 4.0. 
A Cosmopolítica da Gestação, do Parto e do Pós-Parto: autoatenção e medicalização entre os índios Munduruku 


\author{
FUNDAÇÃO OSWALDO CRUZ \\ Presidente \\ Nísia Trindade Lima \\ Vice-Presidente de Educação, Informação e Comunicação \\ Manoel Barral Netto
}

\title{
EDITORA FIOCRUZ \\ Diretor
}

Manoel Barral Netto

Editor Executivo

João Carlos Canossa Mendes

Editores Científicos

Carlos Machado de Freitas

Gilberto Hochman

Conselho Editorial

Denise Valle

José Roberto Lapa e Silva

Kenneth Rochel de Camargo Jr.

Lígia Maria Vieira da Silva

Marcos Cueto

Maria Cecília de Souza Minayo

Marilia Santini de Oliveira

Moisés Goldbaum

Rafael Linden

Ricardo Ventura Santos

Coleção Saúde dos Povos Indígenas

Editores Responsáveis: Ricardo Ventura

Carlos E. A. Coimbra Jr. 
A Cosmopolítica da Gestação, do Parto e do Pós-Parto: autoatenção e medicalização entre os índios Munduruku

Raquel Paiva Dias Scopel

$2^{\mathrm{a}}$ edição revista 
Copyright (C) 2018 da autora

Todos os direitos desta edição reservados à

FUNDAÇÃO OSWALDO CRUZ / EDITORA

$2^{\mathrm{a}}$ edição, revista, de A Cosmopolítica da Gestação, Parto e Pós-Parto: práticas de autoatenção

e processo de medicalização entre os índios Munduruku. Brasília: ABA-GIZ, Paralelo 15, 2015.

Revisão

Irene Ernest Dias

Normalização de referências

Clarissa Bravo

Capa

Danowski Design

Criada a partir de grafismo corporal munduruku em gravura do séc. XIX

Projeto gráfico

Angélica Mello

Daniel Pose

Editoração

Robson Lima (Obra Completa Comunicação)

Produção editorial

Phelipe Gasiglia

Catalogação na fonte

Fundação Oswaldo Cruz

Instituto de Comunicação e Informação Científica e Tecnológica em Saúde

Biblioteca de Saúde Pública

S422c Dias-Scopel, Raquel Paiva.

A Cosmopolítica da gestação, do parto e do pós-parto: autoatenção e medicalização entre os índios Munduruku / Raquel Paiva Dias-Scopel. - Rio de Janeiro : Editora FIOCRUZ, 2018.

210 p. : il. (Coleção Saúde dos Povos Indígenas)

ISBN: 978-85-7541-621-1

1. Índios Sul-Americanos. 2. Gravidez. 3. Assistência Integral à Saúde. 4. Saúde da Mulher. 5. Medicalização. 6. Parto. 7. Período Pós-Parto. 8. Saúde de Populações Indígenas. 9. Política Pública.

I. Título.

2018

EDITORA FIOCRUZ

Av. Brasil, 4036, térreo, sala 112 - Manguinhos

21040-361 - Rio de Janeiro, RJ

Tels.: (21) 3882-9039 e 3882-9041

Telefax: (21) 3882-9006

editora@fiocruz.br

www.fiocruz.br

Editora filiada

Associação Brasileira das Editoras Universitárias 
Às mulheres e aos homens Munduruku que me ensinaram a viver o dia a dia da aldeia com paciência, alegria e disposição

Aos amores Daniel, Leonardo e Giovanna Angelina, com quem compartilho as aventuras na vida 
Sumário

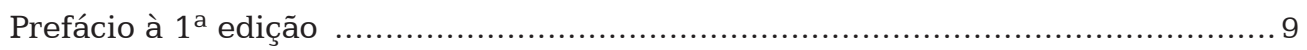

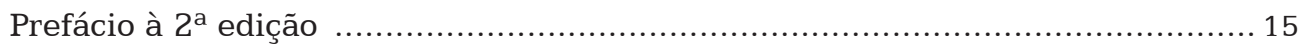

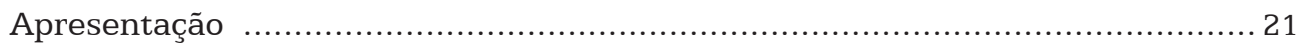

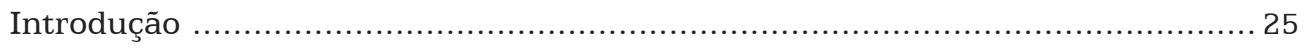

1. A Pesquisa de Campo, a Metodologia e a Contextualização Histórica ............. 39

2. O Cotidiano dos Munduruku: a vida na aldeia Kwatá ..................................... 57

3. As Práticas de Autoatenção à Gestação .................................................... 99

4. Participação da Gestante Munduruku no Programa de Assistência Integral à Saúde da Mulher ................................................................. 127

5. Práticas de Autoatenção Relativas ao Parto: pluralidade de sistemas médicos, articulação e autonomia relativa ..................................... 137

6. Atenção Diferenciada e Medicalização da Gestação, do Parto e do Pós-Parto... 155

7. O Cotidiano e o Extraordinário: o resguardo entre os Munduruku .............. 167

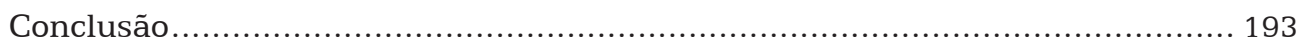

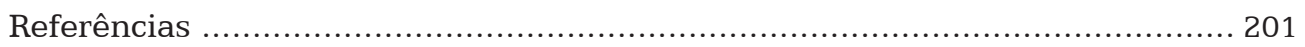




\section{Prefácio à $1^{\mathrm{a}}$ edição}

É com grande prazer que apresento este livro de Raquel, fruto de sua pesquisa de doutorado entre os Munduruku e da tese que foi laureada no IV Prêmio ABA-GIZ, sobre a temática de "Gênero e povos indígenas na Amazônia". Raquel foi minha orientanda na Universidade Federal de Santa Catarina desde a graduação até o doutorado. Sempre teve interesse na antropologia da saúde, e sua pesquisa para o trabalho de conclusão de curso foi sobre a depressão pós-parto entre as mulheres da classe popular em Florianópolis (SC). Desde o mestrado ela vem trabalhando no campo de saúde indígena, no qual nos oferece uma importante contribuição como pesquisadora.

Sua dissertação de mestrado, "O agente indígena de saúde Xokleng: por um mediador entre a comunidade indígena e o serviço de atenção diferenciada à saúde - uma abordagem da antropologia da saúde" (Dias-Scopel, 2005), fez parte de uma pesquisa mais ampla: "O subsistema de atenção à saúde do índio em Santa Catarina (Distrito Sanitário Especial Indígena Interior Sul): o papel do Agente Indígena de Saúde" (Projeto 326/2003 - Fapesc/Unesco-MS); Langdon et al., 2006; Dias-Scopel, Langdon G Scopel, 2007). Essa pesquisa foi realizada pelos membros do Núcleo de Saberes e Saúde Indígena (Nessi/UFSC) entre 2004 e 2005 e visava ao acompanhamento e à análise da formação e do papel do agente indígena de saúde (AIS) na atenção básica dirigida às comunidades indígenas de Santa Catarina. Raquel contribuiu para o desenvolvimento desse projeto, e ainda para o filme que realizamos sobre esse grupo (Langdon G Wiik, 2008). Sua primeira viagem para a TI Laklãnõ foi durante a filmagem e, subsequentemente, ela morou na terra indígena durante vários meses para realizar a pesquisa qualitativa de sua dissertação do mestrado.

Logo depois da conclusão do mestrado, Raquel entrou como pesquisadora no Instituto de Pesquisa Leônidas e Maria Deane/Fiocruz Amazônia, mantendo seu vínculo com o Nessi e dando continuidade a nossas pesquisas em saúde indígena, dentre as quais aquelas sobre os AISs (Diehl, Langdon G Dias-Scopel, 2012; Langdon, Diehl G Dias-Scopel, 2014). Raquel foi mesmo a responsável pelo acordo de cooperação técnico-científica estabelecido entre a Fiocruz Amazônia e a UFSC para a colaboração em pesquisa visando à comparação do modelo de atenção diferenciada 
entre os Kaingang de Santa Catarina e os Munduruku do Amazonas. Esse projeto foi importante para a definição da pesquisa de doutorado que Raquel realizou entre 2009 e 2011.

Relato aqui seu papel nas atividades do Nessi para ressaltar que, desde o início de seus estudos em antropologia, Raquel demonstrava uma capacidade e dedicação não usual para uma pessoa em início da carreira. Como orientadora, foi um grande prazer acompanhar seu desenvolvimento ao longo de todos estes anos. Não cabe relatar todas suas publicações nem as apresentações em congressos de antropologia e saúde coletiva, mas quero destacar que a pesquisa contida neste livro faz parte da trajetória de uma pesquisadora jovem que tem demonstrado duas capacidades especiais - a realização da pesquisa qualitativa de longa duração no modo clássico da antropologia e a colaboração em grupos e redes de pesquisa que visam desenvolver o campo interdisciplinar de saúde indígena.

O trabalho do doutorado foi apoiado com recursos do INCT: Brasil Plural (MCTI/CNPq/Capes/Fapesc/Fapeam) no âmbito da rede de pesquisa do IBP "Saúde: práticas locais, experiências e políticas públicas", realizada por pesquisadores da área de antropologia e de outras disciplinas (nutrição, farmácia, sociologia, psiquiatria, medicina e enfermagem). Essa rede interinstitucional parte da colaboração entre os pesquisadores da UFSC e da Fiocruz Amazônia que vêm contribuindo para a construção do campo da antropologia da saúde, com particular preocupação com a articulação entre os resultados de pesquisa com as práticas de atenção e as políticas púbicas. Essa colaboração teve início há mais de vinte anos, quando os pesquisadores se conheceram através do engajamento na investigação dos processos de saúde e doença a partir de uma perspectiva antropológica para contribuir com a discussão teórico-analítica para a implantação de políticas públicas de saúde indígena.

Os pesquisadores da UFSC e da Fiocruz Amazônia têm sido pioneiros nas pesquisas sobre a compreensão das condições de saúde, dos serviços e da política direcionada aos povos indígenas. A colaboração se caracteriza pelo esforço de desenvolver uma abordagem antropológica da saúde capaz de dialogar com as ciências e as políticas de saúde (Garnelo G Langdon, 2005). O enfoque não é exclusivamente limitado à questão indígena e temos uma articulação estreita com a problemática analítico-teórica da rede geral que examina a relação entre saúde, sociedade e políticas públicas.

Junto a pesquisadores da Colômbia e do México exploramos a inovação em conceitos analíticos adequados para o contexto latino-americano, tais como "etnoepidemiologia" (Portela Guarín, 2008), "epidemiologia sociocultural" (Haro, 2010) e "práticas de autoatenção" (Menéndez, 2009). Visamos construir um diálogo sobre a antropologia da saúde na América Latina e suas contribuições para as políticas públicas numa perspectiva comparativa (Langdon G Cardoso, 2015). A metodologia está ancorada na pesquisa qualitativa de longa duração (Menéndez, 
2012) e no potencial de seus resultados para a atenção à saúde e o desenvolvimento de políticas públicas num contexto de diversidade de saberes e culturas.

$\mathrm{O}$ estudo de Raquel demonstra como é frutífero o desenvolvimento dos paradigmas antropológicos para a compreensão de modelos de atenção e sob a perspectiva dos atores nos contextos locais. Relata com profundidade extraordinária como os Munduruku se organizam para garantir que a gravidez proceda normalmente e resulte num parto sem problemas e numa criança saudável. Essas práticas remetem a uma cosmografia e visão do corpo que vai além da visão de gravidez e seus cuidados pela biomedicina. Demonstra a capacidade das famílias Munduruku no gerenciamento da gravidez, articulando os saberes e os especialistas tradicionais com os serviços oficiais de saúde acessíveis.

A autora explora a agência dos Munduruku nos contextos de gravidez, parto e pós-parto através dos conceitos de "modelos de atenção à saúde" e "práticas de autoatenção" de Eduardo Menéndez (2009), colaborador de nossa rede de pesquisa no México. Assim, as informações apresentadas não partem de uma visão limitada de "etnomedicina" ou "saúde indígena". Identifica todos os recursos terapêuticos empregados na busca de prevenção, tratamento, controle, alívio e cura acessados no processo de gravidez, parto e pós-parto, incluindo a articulação com os serviços oficiais oferecidos pelo Subsistema de Saúde Indígena.

O conceito central, as práticas de autoatenção, compreende

as representações e práticas que a população utiliza no nível do sujeito e do grupo social para diagnosticar, explicar, atender, controlar, aliviar, aguentar, curar, solucionar ou prevenir os processos que afetam sua saúde em termos reais ou imaginários, sem a intervenção direta, central e intencional de curadores profissionais. (Menéndez, 2009: 48)

Menéndez sublinha, portanto, o caráter autônomo dessas práticas. Segundo ele, existem dois níveis em que as práticas de autoatenção podem ser pensadas: o primeiro, mais amplo, está ligado a todas as formas de autoatenção necessárias para assegurar a reprodução biossocial dos sujeitos e grupos no nível dos microgrupos, em especial do grupo doméstico. Assim, a autoatenção neste nível inclui não apenas o cuidado e a prevenção das enfermidades, mas também usos de recursos corporais e ambientais, dietética, normas de higiene pessoal e coletiva, organização social, rituais, e assim por diante. Este conceito remete à relação de saúde como parte da práxis e cosmologia. O segundo nível, mais restrito, refere-se principalmente às estratégias, científicas e não científicas, de representação da doença e de práticas de cura e cuidados.

Menéndez (2012) defende que a pesquisa etnográfica centrada nos sujeitos e grupos sociais revela a forma pela qual esses diferentes modelos de atenção se articulam nos itinerários terapêuticos individuais, nos quais, muitas vezes, apare- 
cem combinadas práticas terapêuticas e noções sobre saúde-doença que em outras instâncias são definidas como antagônicas ou excludentes. Através das mulheres Munduruku, que se inserem em redes de trocas de conhecimentos, constroem-se influências mútuas entre diferentes modelos de atenção à saúde. Desta maneira, as práticas e concepções a respeito da gravidez, do parto e do pós-parto são construídas e reconstruídas num processo contínuo.

Resumindo: o conceito fundamental deste livro - a autoatenção - aponta para o reconhecimento da autonomia e da criatividade da coletividade, principalmente da família, como núcleo que articula os diferentes modelos de atenção ou cuidado da saúde. Diferentemente do conceito médico de autocuidado, o conceito de Menéndez adotado como eixo de análise da pesquisa desloca a ação do profissional de saúde para os Munduruku como coletividade. Enquanto o primeiro trata da adequação do paciente para incorporar os valores e as instruções da biomedicina, o segundo, base de análise neste livro, trata de sua autonomia na articulação dos recursos terapêuticos acessíveis, independentemente de sua origem, e na criação de articulações novas.

Como Raquel demonstra claramente neste estudo, apesar da expansão da biomedicina através do Subsistema de Saúde Indígena, os serviços de atenção à saúde oferecidos não suplantam outras formas de conhecimento. Pelo contrário, ao mesmo tempo que a biomedicina se expande, as práticas de saúde populares e alternativas também florescem. Dessa maneira, as dinâmicas relacionadas à saúde-doença são caracterizadas por uma negociação entre diferentes práticas e formas de conhecimento, sendo que, muitas vezes, neste processo, formam-se novas sínteses e hibridações.

A autora procura dar conta das diversas formas através das quais os Munduruku acionam os variados sistemas terapêuticos no processo de gravidez e de parto. Procura ressaltar aspectos como a interação e a relacionalidade inerentes às práticas sociais. As práticas, os conceitos e as ações sobre o corpo e a gravidez articulam-se com a ordem sociocosmológica. A ênfase de Raquel para entender a perspectiva dos Munduruku e reconhecer sua capacidade de agência revela que é a partir dos sujeitos e/ou grupos sociais que são construídas as articulações entre os diferentes conceitos e práticas relacionados ao processo de saúde-doença; muitas vezes essas articulações se dão através de ações que recombinam elementos das mais variadas esferas e produzem outros aspectos do social. Assim, este estudo antropológico traz para o campo da saúde coletiva uma visão da coletividade e o reconhecimento dos saberes plurais, a autonomia dos atores e as especificidades das situações locais em paralelo com os processos estruturais de expansão da forma de atenção biomédica.

Em sua abordagem, a autora parte do paradigma do processo saúde-doença como socialmente construído, contextual e internacionalmente, e da premissa de que os diferentes modelos médicos têm especificidades e estão em constante 
reconfiguração e interlocução. Ao se concentrar especificamente nas práticas de autoatenção sobre gravidez, parto e pós-parto dos Munduruku, a pesquisa ressalta o caráter dinâmico e processual das práticas ligadas ao cuidado da saúde, bem como as ações de articulação entre diferentes conhecimentos e saberes, com o intuito de descrever e analisar as particularidades, interações, negociações e conflitos existentes nos processos sociais.

Esta pesquisa se caracteriza por sua natureza clássica de etnografia, longos períodos de campo de convivência com o grupo para entender as preocupações e práticas de autoatenção no sentido lato que remete à perspectiva maior de processos corporais, sociocosmológicos e de identidade.

Raquel, junto com seu marido e companheiro em pesquisa, vem realizando uma contribuição importante para a antropologia e a saúde coletiva (Scopel, 2013; Dias-Scopel, 2014; Scopel, Dias-Scopel G Wiik, 2012). Para esta etnografia, a metodologia de observação participante guiou a investigação no sentido literal, dado que Raquel estava grávida durante sua estadia em campo. Isso permitiu e estimulou um diálogo simétrico e profundo com as mulheres e os homens indígenas, e seus saberes e capacidades de ação estão na base das ricas informações contidos neste livro.

\section{Esther Jean Langdon}

Doutora em antropologia, professora titular da Universidade Federal de Santa Catarina e coordenadora do Instituto Nacional de Pesquisa Brasil Plural

\section{Referências}

DIAS-SCOPEL, R. P. O Agente Indígena de Saúde Xokleng: por um mediador entre a comunidade indígena e o serviço de atenção diferenciada à saúde - uma abordagem da antropologia da saúde, 2005. Dissertação de Mestrado, Florianópolis: Programa de Pós-Graduação em Antropologia Social, Universidade Federal de Santa Catarina.

DIAS-SCOPEL, R. P. A Cosmopolítica da Gestação, Parto e Pós-Parto: práticas de autoatenção e processo de medicalização entre os índios Munduruku, 2014. Tese de Doutorado, Florianópolis: Programa de Pós-Graduação em Antropologia Social, Universidade Federal de Santa Catarina.

DIAS-SCOPEL, R. P.; LANGDON, E. J. G SCOPEL, D. Expectativas emergentes: a inserção do agente indígena de saúde Xokleng na equipe multidisciplinar de atenção à saúde indígena. Tellus, 13: 51-73, 2007.

DIEHL, E. E.; LANGDON, E. J. G DIAS-SCOPEL, R. Contribuição dos agentes indígenas de saúde na atenção diferenciada à saúde dos povos indígenas brasileiros. Cadernos de Saúde Pública, 28(5): 819-831, 2012. 
GARNELO, L. G LANGDON E. J. A antropologia e a reformulação das práticas sanitárias na atenção básica à saúde. In: MINAYO, M. C. S. G COIMBRA JR., C. E. A. (Orgs.). Críticas e Atuantes: ciências sociais e humanas em saúde na América Latina. Rio de Janeiro: Editora Fiocruz, 2005.

HARO, J. A. (Org.). Epidemiología Sociocultural: un diálogo en torno a su sentido, métodos $y$ alcances. Buenos Aires: Lugar Editorial, Centro de Estudios en Salud y Sociedad, El Colegio de Sonora, 2010.

LANGDON, E. J. G WIIK, F. B. Festa de inauguração do Centro de Turismo e Lazer: uma análise da performance identitária dos Laklãnõ (Xokleng) de Santa Catarina. Ilha, 10(1): 171-199, 2008.

LANGDON, E. J.; DIEHL, E. E. G DIAS-SCOPEL, R. P. O papel e a formação dos Agentes Indígenas de Saúde na atenção diferenciada à saúde aos povos indígenas brasileiros. In: TEIXEIRA, C. G GARNELO, L. (Orgs.). Saúde Indígena em Perspectiva: explorando suas matrizes históricas e ideológicas. Rio de Janeiro: Editora Fiocruz, 2014. (Coleção Saúde dos Povos Indígenas)

LANGDON, E. J. et al. A participação dos agentes indígenas de saúde nos serviços de Atenção à Saúde: a experiência em Santa Catarina (Distrito Sanitário Especial Indígena Interior Sul). Cadernos de Saúde Pública, 22(12): 2.637-2.646, 2006.

LANGDON, E. J. G CARDOSO, M. D. (Orgs.). Saúde Indígena: políticas comparadas na América Latina. Florianópolis: Editora da UFSC, 2015.

MENÉNDEZ, E. L. Sujeitos, Saberes e Estruturas: uma introdução ao enfoque relacional no estudo da saúde coletiva. São Paulo: Hucitec, 2009.

MENÉNDEZ, E. L. Metodología cualitativa: varios problemas y reiteradas omisiones. Index de Enfermería, 21(1-2): 62-68, 2012.

PORTELA GUARÍN, H. La Epidemiologia Intercultural: argumentaciones, requerimientos $y$ propuestas. Popayan: Editorial Universdad del Cauca, 2008.

SCOPEL, D. Uma Etnografia sobre a Pluralidade de Modelos de Atenção à Saúde entre os Índios Munduruku na Terra Indígena Kwatá Laranjal, Borba, Amazonas: práticas de automação, xamanismo e biomedicina, 2013. Tese de Doutorado, Florianópolis: Universidade Federal de Santa Catarina.

SCOPEL, D.; DIAS-SCOPEL, R. P. G WIIK, F. B. Cosmologia e intermedicalidade: o campo religioso e a autoatenção às enfermidades entre os índios Munduruku do Amazonas, Brasil. Tempus Actas de Saúde Coletiva, 6(1): 173-190, 2012. 


\section{Prefácio à $2^{\mathrm{a}}$ edição}

Felicito a Editora Fiocruz e Raquel Dias-Scopel pela publicação de mais um volume da coleção Saúde dos Povos Indígenas, no qual encontramos um vívido retrato dos modos de gestar e parir das mulheres Munduruku.

A autora desenvolve uma primorosa análise do contexto que rege a saúde reprodutiva na etnia Munduruku, tratada à luz da cosmopolítica do grupo. Destaca, em primeiro plano, interfaces possíveis entre a progenitura humana e as linhagens das sociedades não humanas que - de acordo com as produções culturais do grupo - partilham um mesmo território onde ancestralmente se desenvolve a coexistência que atribui sentido às ideias reprodutivas dos Munduruku. Para estes, o processo reprodutivo humano assume um caráter de ação política na qual se produz parentela humana e se instituem as bases das relações futuras de afinidade com que é construída a urdidura do tecido social. De modo similar o processo reprodutivo se estende à alteridade não humana, de quem dependem os Munduruku para garantir a reprodução dos ciclos da natureza que, por sua vez, retroalimentam a vida humana.

As práticas relacionadas aos cuidados na gravidez se manifestam como atualização cotidiana de tradições ancestrais, permitindo reavivar tanto os vínculos de consanguinidade quanto a familiarização de afins e de corresidentes não consanguíneos, ampliando e aprimorando laços que garantem a vida em sociedade. Nesse âmbito, Dias-Scopel demonstra com propriedade a importância da alimentação, caracterizada na gestação como um "circuito de trocas e compartilhamento de substâncias", que constrói o corpo e a pessoa do novo membro do grupo, cuja presença reafirma a linha de continuidade das linhagens humanas e é alvo de negociação com as entidades cósmicas, que podem favorecer ou cobiçar para si a descendência humana. Tal concepção do processo reprodutivo o converte num vetor que percorre todos os níveis da existência, assumindo simultaneamente o caráter de um evento individual, familiar, sociocomunal e sociocósmico.

Produção e reprodução humana são vistas como intimamente relacionadas, fato que Raquel Dias-Scopel exemplifica com os afazeres cotidianos para produzir alimentos. No mundo indígena fazer farinha é uma ação rotineira, necessária à subsistência familiar, que exige a atuação conjunta dos dois membros da parelha 
conjugal. Sendo rotineira, tal atividade abriga e esconde inusitadas dimensões de continuidade entre produzir o alimento e produzir bebês, que se mostram como aspectos distintos de um único e importante evento, o de produzir a vida. Nesse contexto, a realização de práticas alimentares cotidianas tem severa repercussão positiva ou negativa - na integridade, saúde e sobrevivência do bebê. O fluxo oposto também é demonstrado, na medida em que às mulheres menstruadas, grávidas ou paridas certas ações são interditas sob pena de se comprometer a qualidade do alimento produzido e/ou de se atrair a atenção de pessoas não humanas invejosas ou ciumentas do sucesso reprodutivo de nossa espécie (Arhem, 2001).

A etnologia dos povos das terras baixas sul-americanas já atestou que nessas sociedades muitos concebem a corporalidade como um devir permanente que exige ativo e reiterado trabalho de construção ao longo de toda a vida (Castro, 1987; Seeger, Da Matta G Viveiros de Castro, 1979; Garnelo, 2007). No caso munduruku, o estudo de Dias-Scopel apreende não apenas a produção social do corpo e da pessoa da criança, iniciado ainda no ventre, mas também da mulher adulta quando se torna mãe. Gravidez, parto e pós-parto são momentos de verdadeira reconstrução do corpo feminino, visando a potencializar o sucesso, atual e futuro, de sua capacidade reprodutiva. É esta que garante, em última instância, o sucesso reprodutivo de todos nós, fazendo pender a favor da humanidade o balanço do equilíbrio cósmico com a alteridade (Bellier, 1993).

Ao mapear conexões entre a produção de alimentos e a de crianças, a autora nos brinda com importante chave de acesso às relações entre a capacidade reprodutiva e a cosmografia munduruku. Remete o cotidiano reprodutivo das pessoas à produção de territórios que se tornam disponíveis para o aldeamento humano e propiciam o usufruto de lugares para pescar, fazer roças e se deslocar em viagens rotineiras, ainda que a disputa com os seres-espíritos que habitam espaços aquáticos, subterrâneos, do ar e da selva jamais cesse de fato.

A tradição ensinou os Munduruku a praticar um seguro distanciamento dos locais reconhecidos como moradia dos seres-espíritos, conduta tida como a mais adequada para se lidar com a alteridade. Porém, é impossível evitar completamente tais vizinhos, e a ocorrência de encontros inesperados - em geral não desejados não é algo incomum, gerando consequências imprevisíveis, como costuma ocorrer nesse tipo de evento, do qual os humanos jamais saem completamente indenes (Lima, 2005).

O delicado período de produção de novos seres humanos, que no entendimento munduruku abrange desde a primeira menstruação até o pós-parto e gestações subsequentes, favorece a "abertura" do ser feminino - e por consequência de toda sua comunidade de substância - a tais seres, não sendo desprezível o risco - reconhecido pelos membros do grupo - de que uma mulher engravide de um "encantado". Trata-se de eventualidade nada trivial, tendo mesmo repercussões 
cósmicas, já que coloca em xeque a perpetuação da prole humana, abrindo a possibilidade de um futuro dominado pela alteridade (Garnelo, 2007).

A rarefação dessas fronteiras é reconhecida como ameaça à saúde da gestante, da criança e mesmo do pai ou outros consanguíneos. É temida pelos Munduruku, mas desconhecida dos profissionais da saúde, habitualmente preocupados com os vírus, as bactérias e as disfunções da fisiologia corporal, esquecidos de que o viver humano não se limita ao plano biológico da existência.

Se o rompimento da fronteira com a alteridade, estabelecida desde tempos imemoriais, é quase inevitável num espaço povoado por múltiplas "gentes", tais eventos mostram que o desencantamento do mundo, apontado por Weber como demarcador da razão ocidental, ainda não ocorreu entre os Munduruku, ou pelo menos coexiste com as instituições escolares e de saúde, com a economia de mercado e com a internet, presentes de modo indelével nas aldeias.

É sobre essa complexa cosmografia que Raquel Dias-Scopel situa o fulcro central da potência reprodutiva feminina, deixando a nós, profissionais da saúde, constrangidos por constatar, mais uma vez, quão reducionistas são as políticas e as práticas de atenção à saúde da mulher, tal como preconizadas e executadas no Sistema Único de Saúde e no seu Subsistema de Atenção à Saúde Indígena (Sasisus).

Nos próprios termos da autora, as práticas de autoatenção à gestação e ao parto entre os Munduruku se assentam na ideia de que "é o corpo social no qual o corpo individual está inserido que ocupa o centro das atenções dos Munduruku". Ou seja, temos aqui a constatação munduruku de que saúde e doença não devem ser vistas como eventos meramente individuais. Pelo contrário, sua gênese, seu desenvolvimento e suas consequências são sociais e, no caso indígena, sociocósmicos, já que englobam também as relações com entidades não humanas (Arhem, 2001).

Ora, mesmo que não compartilhemos a ideia munduruku de que o plano humano é mais um entre múltiplas dimensões cósmicas, temos aí uma afirmação preciosa: a de que a gênese das condições de saúde deve ser procurada na estrutura social. Trata-se de uma ideia fugidia no campo da saúde pública sempre perseguida pelos teóricos das determinações sociais em saúde, mas nunca incluída nas práticas profissionais da rede de atenção primária à saúde, profundamente colonizadas pelo reducionismo biomédico. Para os Munduruku, porém, essa é uma certeza que guia a práxis dos cuidados rotineiros com a gestação e o parto.

Igualmente importante é a potencialidade deste panorama da vida reprodutiva munduruku para nos conduzir a uma ampla e detalhada visão dos meandros dessa cultura, e mais ainda, sobre os modos como os membros do grupo produzem sua própria modernidade no contexto da globalização que os alcança, tal como a todos nós.

Tais abordagens se ligam diretamente a uma concepção apenas esboçada - mas nunca desenvolvida - na Política Nacional de Saúde dos Povos Indígenas 
(Pnaspi), que é a chamada "atenção diferenciada". O termo foi cunhado para ressaltar as especificidades que a atenção à saúde ofertada aos povos indígenas deveria assumir e para expressar a necessária sensibilidade cultural preconizada para esta política pública. Porém, ao longo do processo de implantação do Sasisus não se observou movimentação significativa por parte do poder público, para aclarar o sentido desse princípio orientador da Pnaspi e muito menos para promover sua expressão no plano prático das atividades das equipes de saúde que atuam nos Distritos Sanitários Especiais Indígenas (DSEIs).

Em que pese a omissão do poder público em delinear adequadamente como a atenção diferenciada deveria se transfigurar em práxis, antropólogos como Jean Langdon (2007) têm se debruçado sobre o tema, com uma mirada que também encontramos na pesquisa de Dias-Scopel. Se olhadas com atenção, as chaves interpretativas e pistas geradas pela obra que aqui prefaciamos podem ofertar guias para que os profissionais da saúde que atuam nos DSEIs possam buscar estratégias que lhes permitam entender o que os Munduruku - e, por que não, também outras etnias - pensam, sentem e os valores que atribuem no campo da saúde reprodutiva.

Este é um dos melhores presentes com que Raquel nos brinda: preciosas pistas que ampliam a visão sobre o tema da saúde reprodutiva indígena e liberam os pensamentos da camisa de força da biomedicina que restringe os cuidados com a gestação, o parto e o pós-parto aos seus aspectos meramente biológicos. Sua obra nos convida a adentrar a riqueza da visão de mundo do grupo e a perceber, como fazem os Munduruku, o processo reprodutivo como construção sociocultural e historicamente situada, que remete à estrutura social e à visão de mundo do grupo, conferindo-lhe sentido ontológico e congruência com seus modos de vida.

A esta altura talvez o leitor se pergunte o que espíritos, cosmologias, e parentesco têm a ver com a atenção à saúde, já que se publica para um público e numa editora interessados na temática da saúde. De imediato, aponto nítidas conexões entre dois enfoques caros aos profissionais da saúde coletiva: a integralidade e o cuidado.

Em importante publicação em que explorou fundamentos teóricos e nuances assumidas pela noção de integralidade, Mattos (2001) explora a polissemia do termo. Dos diversos sentidos da integralidade apontados pelo autor destacarei dois. O primeiro é o entendimento da integralidade como atributo das práticas dos profissionais da saúde, as quais devem se pautar pela capacidade de reconhecer as necessidades dos sujeitos que atendem, não se restringindo à sintomatologia física. Ora, esse é um dos produtos do mapeamento feito por Dias-Scopel em sua análise da vida reprodutiva munduruku. A demonstrada complexidade e amplitude de seus sentidos deixou claro para todos que, longe de se resumir a transformações corporais cíclicas ou transitórias, o potencial reprodutivo feminino permeia múltiplas dimensões da vida material, conjugal, valorativa e cosmológica do grupo estudado. 
Além disso, Mattos também situa a integralidade como uma imagemobjetivo, um propósito que se almeja alcançar, em obediência a um "um conjunto de valores pelos quais vale lutar, pois se relacionam a um ideal de uma sociedade mais justa e mais solidária" (2001: 41). De tais finalidades trata boa parte da obra de Dias-Scopel: trata-se do propósito de desvendar nuances do pensamento e dos valores munduruku contribuindo para que se alcance uma atenção culturalmente adequada, capaz de se aproximar da imagem-objetivo da atenção diferenciada proposta pela Pnaspi.

A discussão da literatura sobre a integralidade é um convite a persistir na luta por "valores pelos quais vale a pena lutar" (Mattos, 2001) também na saúde indígena, ou seja, a insistir em que a atuação do subsistema se paute pela integralidade, tratada como um caminho que inclui o conhecimento dos valores e conhecimentos indígenas, como aqui foi feito por Dias-Scopel, e entendida como o modo mais efetivo de diálogo, aproximação e formação de vínculos, que permitam que os profissionais passem a tratar os sujeitos, e não somente as doenças.

$\mathrm{O}$ outro conceito no qual enxergo importante interface com a investigação de Dias-Scopel é o de cuidado. É, mais uma vez, Mattos (2001) que nos alerta sobre a modernização do higienismo, que, travestido pelas reluzentes e modernas tecnologias de diagnóstico e tratamento, se torna ainda mais eficiente na prevenção de agravos e mortes. Porém, nele persiste um projeto, implicitamente etnocêntrico, que implanta tecnologias reprodutivas que não apenas salvam os corpos, mas também os regulam e os domesticam. Não se pode ignorar que os cuidados com a saúde reprodutiva também contribuem para retirar a capacidade de agência dos sujeitos, para disciplinar os processos reprodutivos dos pobres e excluídos que vivem nas franjas da sociedade ocidental (Mattos, 2005) e para comprometer o ideário coletivista e totalizante de grupos étnicos como os Munduruku.

A recusa de muitas sociedades indígenas a fracionar a realidade em individual e grupal e a insistência em manter um corpo coletivo de pessoas que convivem e partilham necessidades comuns e interatuam para produzir a vida, a saúde e até mesmo a doença, contrasta fortemente com o modo individualizante assumido pela oferta de cuidados e definição de prioridades na rede assistencial. Em tais circunstâncias o cuidado em saúde, em particular quando fortemente tecnificado, pode assumir um caráter disruptivo ao competir e se sobrepor às formas totalizantes do cuidado ofertado aos moldes indígenas. Este corre o risco de sucumbir ao fetiche da técnica e ao desconhecimento indiferente dos profissionais da saúde que não compreendam a visão de mundo das minorias étnicas junto às quais foram chamados a atuar (Coimbra G Garnelo, 2004).

A mais contundente mensagem da obra de Dias-Scopel, para além do desvendamento da cosmopolítica da gravidez e do parto no grupo que estudou, é chamar nossa atenção para a importância e a necessidade de que os profissionais 
que atuam nos DSEIs se familiarizem com as concepções, valores e práticas das sociedades indígenas om as quais trabalham, instituindo assim vínculos dialógicos e polifônicos em que a voz a ser ouvida não seja apenas a da razão técnica, mas também a do direito à vida, a ser diferente e a preservar a capacidade de escolher seus modos de viver e de se reproduzir.

\section{Luiza Garnelo}

Doutora em antropologia, membro do corpo docente do Programa de Pós-Graduação em Saúde Coletiva e pesquisadora do Centro de Pesquisas Leônidas G Maria Deane - Fiocruz Manaus e professora visitante da Universidade Nilton Lins

Referências

ARHEM, K. La red cósmica de la alimentación. In: DESCOLA, P. G PÁLSSON, G. Naturaleza y Sociedad: perspectivas antropológicas. México: Siglo Veintiuno, 2001.

BELLIER, I. Réflexions sur la question du genre dans les sociétés amazoniennes. L'Homme, 33: 517-526, 1993.

CASTRO, E. B. V. A fabricação do corpo na sociedade xinguana. In: OLIVEIRA, J. P. (Org.). Sociedades Indígenas e Indigenismo no Brasil. Rio de Janeiro: Marco Zero, 1987.

COIMBRA JR., C. E. G GARNELO, L. Questões de saúde reprodutiva da mulher indígena no Brasil. In: MONTEIRO, S. G SANSONE, L. (Orgs.). Etnicidade na América Latina: um debate sobre raça, saúde e direitos reprodutivos. Rio de Janeiro: Editora Fiocruz, 2004.

GARNELO, L. Cosmologia, ambiente e saúde: mitos e ritos alimentares Baniwa. História, Ciências, Saúde-Manguinhos, 14, supl.: 191-212, 2007.

LANDGON, E. J. Diversidade cultural e os desafios da política brasileira de saúde do índio. Saúde e Sociedade, 16: 7-12, 2007.

LIMA, T. S. Um Peixe Olhou para Mim: o povo Yudjá e a perspectiva. 1. ed. São Paulo, Rio de Janeiro: ISA, Editora Unesp, NuTI, 2005.

MATTOS, R. A. Os sentidos da integralidade: algumas reflexões de valores que merecem ser defendidos. In: PINHEIRO, R. G MATTOS, R. (Orgs.). Os Sentidos da Integralidade na Atenção e no Cuidado à Saúde. Rio de Janeiro: IMS/Uerj, Abrasco, 2001.

MATTOS, R. Cuidado prudente para uma vida decente. In: PINHEIRO, R. G MATTOS, R. (Orgs.). Cuidado: as fronteiras da integralidade. Rio de Janeiro: IMS/Uerj, Abrasco, 2005.

SEEGER, A.; DA MATTA, R. G VIVEIROS DE CASTRO, E. A construção da pessoa nas sociedades indígenas brasileiras. Boletim do Museu Nacional (Antropologia), 32: 2-19, 1979. 


\section{Apresentação}

É um prazer apresentar a segunda edição deste livro pleno de significados. Em 2017, retornei à aldeia Kwatá com meu marido, Daniel, e meus dois filhos, Leonardo (com 5 anos) e Giovanna (com 1 ano e 10 meses). Foi uma experiência fantástica rever os amigos e observar a interação das crianças eufóricas por aprenderem e ensinarem muitas brincadeiras. Nossos anfitriões ficaram muito felizes em conhecer meus filhos. As mulheres que vivenciaram comigo minha experiência de gestação na aldeia, que "pegaram minha barriga", fizeram banhos terapêuticos para mim, compartilharam comidas, prescreveram restrições alimentares, diagnosticaram meu marido com "abalo de criança", entre outras tantas trocas de saberes e orientações, agora queriam saber como havia sido o meu parto, detalhes da amamentação e dos cuidados diurnos e noturnos com meus filhos. Como antropóloga, essa foi uma experiência muito rica que me possibilitou verificar diversas continuidades com o que eu havia escrito anteriormente sobre a vida cotidiana munduruku e, também, outras que ainda pretendo escrever, com um olhar mais detido na infância.

A etnografia aqui apresentada teve sua origem na tese de doutorado defendida em 2014 no Programa de Pós-Graduação em Antropologia Social da Universidade Federal de Santa Catarina e publicada em 2015 pela Associação Brasileira de Antropologia com o título A Cosmopolítica da Gestação, Parto e Pós-Parto: práticas de autoatenção e processo de medicalização entre os índios Munduruku e aborda as práticas cotidianas e rituais voltadas para a construção de corpos saudáveis e fortes e para a formação de pessoas habilidosas, dispostas e cooperativas do ponto de vista munduruku. Um ponto de vista caracterizado por uma perspectiva xamânica do cosmo. Um cosmo habitado por diversos seres dotados de agência e intencionalidades múltiplas, capazes de intervir na vida cotidiana dos Munduruku. Para os Munduruku, as noções de corpo, saúde, doença, pessoa e gênero ganham significados simbólicos particulares, mas não estáticos, pois transmitidos de geração em geração por meio de experiências vividas em um contexto historicamente marcado pelas relações interétnicas com outros povos indígenas, com não indígenas e com uma diversidade de agentes 
sociais de diferentes matrizes religiosas e médicas (Scopel, Dias-Scopel G Wilk, 2012; Scopel, Dias-Scopel G Langdon, 2018).

O ponto de partida desta análise é a etnografia das práticas de atenção à gestação, ao parto e ao pós-parto manejadas por mulheres e homens Munduruku imersos em um contexto de pluralismo médico, onde atuam mulheres mais velhas das famílias extensas, pajés, parteiras, agentes indígenas de saúde, técnicos(as) de enfermagem, enfermeiros(as) e médicos(as). A atuação de cada um desses atores sociais é marcada por diferentes intencionalidades e expectativas nem sempre convergentes. A pesquisa etnográfica evidencia que mulheres e homens Munduruku articulam diferentes formas de atenção à saúde, indígenas e biomédicas, apesar da crescente expansão do modelo biomédico em terras indígenas.

Os Munduruku nos ensinam que a construção dos corpos, das pessoas e das habilidades, consoantes aos valores socialmente compartilhados, são processos sociais que resultam de práticas cotidianas e rituais por meio do envolvimento de diferentes membros da família elementar e extensa. A etnografia desse processo nos conduz a observar algumas limitações no campo da saúde indígena, em particular para a promoção de uma atenção diferenciada conforme preconizado pela Política Nacional de Atenção à Saúde dos Povos Indígenas (Pnaspi) (Brasil, 2002a). A diretriz da atenção diferenciada, como se verá ao longo do volume, convive com uma atenção primária atualizada com base em noções e práticas excessivamente limitadas ao corpo individual e ao tratamento medicamentoso das doenças, caracterizados pelo paradigma biológico e individualista (Menéndez, 2009; Lock, 2004). Para os Munduruku, corpo, saúde e ambiente estão intrinsecamente relacionados e é a devida articulação entre eles, segundo protocolos socialmente compartilhados e cosmologicamente vividos, que possibilita a reprodução biossocial da coletividade (Scopel, Dias-Scopel G Langdon, 2018).

Para os Munduruku, a ação de uma pessoa pode afetar a manutenção da saúde de outras que compartilhem uma mesma rede de relações, do mesmo modo que a agência dos demais seres do cosmo também pode acarretar doenças, infortúnios e morte aos Munduruku. É na tentativa de manter a saúde e prevenir doenças que os Munduruku desenvolvem um conjunto de práticas de autoatenção, em que manejam protocolos de afastamento e aproximação adequados aos demais seres do cosmo, como estratégias de sobrevivência e reprodução biossocial.

O processo de gestação, parto e pós-parto vivenciado pelos Munduruku não pode ser reduzido a uma experiência biológica, obstétrica e individual. Trata-se, antes, de uma experiência articulada em um contexto marcado pela pluralidade de atores, agências e saberes. É nesse sentido que o termo cosmopolítica ganha significado, para afirmar um contexto em que as ações e negociações envolvem diversos atores, entre eles Munduruku, profissionais da saúde brancos e indígenas, "bichos do fundo" e outros seres "encantados". Não se trata 
de imaginar a busca de um consenso de ordem cosmopolita, capaz de abranger as demandas de diferentes atores envolvidos na negociação apenas, conforme bem pontuou Blaser (2016), mas de considerar que para os Munduruku os seres "encantados" também ocupam um lugar de destaque nas ações e negociações que ocorrem no cotidiano da aldeia. É no transcorrer da vida diária que os usos e manejos do corpo e do ambiente podem afetar a saúde individual e coletiva por meio da interferência de seres "encantados" (Scopel, Dias-Scopel e Langdon, 2018). A perspectiva xamânica do cosmo e a ênfase na articulação entre saúde, corpo e ambiente desafia a atualização prática dos princípios expressos pela Pnaspi. Assim, a busca da atenção diferenciada permanece um campo aberto à discussão e uma diretriz pouco clara num cenário em que "a política de desenvolvimento econômico atua contra as necessidades plenas de bem-estar" (Scopel, Dias-Scopel G Langdon, 2018: 89) das populações indígenas no Brasil.

Este livro resulta do envolvimento e participação de muitas pessoas. Agradeço aos Munduruku por terem compartilhado um pouco de seus saberes. Sou grata à Dona Ester, à Nega e ao cacique Manoel Cardoso Munduruku e a sua família. Sem a acolhida dessas pessoas minha pesquisa não teria sido possível.

Na Terra Indígena Kwatá-Laranjal, convivi com muitas pessoas que me receberam em suas casas e dividiram suas horas e atividades de trabalho, pelo que agradeço a todas: Gelson e Hilda, Daniele e Júnior, Juveca e Tuca, Alexandre e Júlia, Marina e Pelé, Isamara e Ederaldo, Baiaka e Bebé, Messias e Alcirema, Eunice e Izaías, Leomara e Alcimir, Ana Greyce e Valni, Ricardo e Rosa, Keké e esposa, Paulo e Dilza, Manoel e Maria Zuma, Jucinei e Vando, Antônio e esposa, Maria Brasil e Raimundo, Maria Izabel, Joana, Filuca, Graciete, Rosinete, Rosana, Aila, Maristela, Ana Mara, Lúcia, Matilde, Emiliano e Magrinho, Valdenice e Edmilson, Zilda e Manoel, Lirão e Clara, Levi e Nivânea, Kleuton. Espero assim estender meus agradecimentos a todos os Munduruku, agentes indígenas de saúde, agentes indígenas de saneamento, professores(as), mães, pais, avós e avôs que compartilharam comigo saberes e me permitiram participar de suas vidas.

Há outros amigos a quem quero agradecer. Agradeço a Jean Langdon, Eliana Elisabeth Diehl, Luiza Garnelo, Carlos Coimbra Jr., Ricardo Ventura Santos e Daniel Scopel pela ajuda, pelo incentivo e pelos diálogos que resultaram na presente edição.

Por fim, agradeço ao Instituto Nacional de Pesquisa Brasil Plural pelo apoio financeiro à realização da pesquisa de campo. À Fundação de Amparo à Pesquisa do Estado do Amazonas agradeço pela bolsa de estudos.

Agradeço à Fundação Oswaldo Cruz, em particular aos diretores Roberto Sena Rocha e Sérgio Luiz Bessa Luz, do Instituto Leônidas e Maria Deane, por apoiarem minha decisão de realizar a pesquisa. E à diretora Jislaine de Fátima Guilhermino, da Fiocruz Mato Grosso do Sul, pela acolhida e confiança. 


\section{Introdução}

\section{Uma abordagem antropológica sobre a saúde indígena em contexto de pluralidade médica}

O que motivou a escrita deste trabalho foi a intenção de apresentar ao leitor como os Munduruku vivenciam a gestação, o parto e o pós-parto em tempos em que se coloca a difícil tarefa de valorizar, reconhecer e respeitar a diversidade étnica e cultural dos povos indígenas no Brasil e a necessidade de minimizar os processos de medicalização da saúde indígena sem, com isso, abrir mão do direito de cidadania de acesso aos serviços de saúde biomédicos. Especialmente porque, do ponto de vista dos Munduruku, a biomedicina não é uma panaceia, e sim um recurso a mais entre outras formas de atenção à saúde com o qual pretendem contar para prevenir, solucionar, minimizar ou tratar questões relativas às enfermidades. Apesar das diferenças entre os saberes biomédicos e os saberes indígenas no trato com a saúde, mulheres e homens Munduruku têm articulado esses saberes no nível das práticas de autoatenção relativas à gestação, ao parto e ao pós-parto (Menéndez, 2003, 2009).

Neste trabalho, práticas de autoatenção referem-se, em sentido lato, às atividades realizadas por sujeitos coletivos ou individuais que implicam a reprodução biossocial do grupo. Em sentido estrito, tais práticas referem-se àquelas manejadas intencionalmente nos processos de saúde-doença-atenção no âmbito familiar de forma relativamente autônoma em relação aos especialistas. ${ }^{1}$ Cumpre esclarecer desde já que a gestação, o parto e o pós-parto não eram tratados como eventos de doença pelos Munduruku. Ainda assim, ocupavam posição central nas preocupações e nos interesses nativos sobre a saúde, na medida em que constituíam parte de um conhecimento acumulado pelas experiências compartilhadas ao longo de gerações que versavam sobre a vitalidade das relações sociais, afetivas e cosmológicas. Os Munduruku compartilhavam assim uma "cosmografia" mantida pelo esforço em gerenciar um distanciamento ideal entre eles e os outros seres que habitam o cosmo. Aqui utilizo o termo cosmografia de acordo com a definição de Little, a qual abran- 
ge "as identidades coletivas, historicamente contingentes, ideologias e sistemas de conhecimento ambiental desenvolvidos por um grupo social para estabelecer e manter o território humano" (Little, 2001: 5, tradução minha).

Para os Munduruku, o cosmo estaria organizado em distintos lugares entre os quais cito aqueles que ocupam papel destacado na vida cotidiana: centro, beira, aldeia, embaixo da terra, fundo do rio e ar -, de tal forma que cada um desses espaços seria habitado por distintos seres. Assim, a cosmografia praticada pelos Munduruku remeteria à inscrição de significados particulares ao seu território. A construção social desses significados abrangia também um conjunto determinado de práticas e de relações sociais na condução adequada da vida cotidiana e convivência com os demais seres do cosmo, o qual constituía parte da cosmopolítica relacionada a questões de saúde e doença. A manutenção de um distanciamento ideal, além de definir espaços e tempos de circulação cotidiana para os Munduruku, estava subsumida em um conjunto de deveres e modos de proceder como formas de garantir e manter a saúde individual e coletiva.

Embora se reconheça, por um lado, nas políticas públicas de saúde voltadas para os povos indígenas no Brasil, que estes produzem e manejam saberes relativos à saúde e doença e a estreita relação entre estes saberes e a dimensão sociocultural e geográfica de cada povo e sua relevância no enfrentamento das enfermidades cotidianas, por outro lado as políticas de Estado, ainda assim, operam reproduzindo uma imagem caricatural e estereotipada do que identificam como medicina indígena. Conforme ressaltaram Ferreira (2013) e Scopel (2013), no Brasil as políticas de Estado acomodam uma definição da medicina indígena sustentada na oposição alegórica entre tradicional e moderno. Esta alegoria colocaria a medicina tradicional no polo de "crenças" do passado, imutável, e os índios como guardiões de um conhecimento "natural" a ser preservado como testemunho do patrimônio da humanidade (Conklin, 2002). No polo oposto estaria a medicina moderna, convencional, científica, tecnológica, em crescente transformação, baseada em evidências, de abrangência e relevância mundial, devendo se estender aos cantos mais remotos do mundo em nome da "boa saúde" ou do "bem-estar" (Lock, 2004).

Os efeitos dessa alegoria sobre a "medicina tradicional indígena" repercutem diretamente na concepção das políticas públicas de saúde e na atuação dos profissionais da saúde que tendem a essencializar as formas de atenção à saúde e às enfermidades praticadas pelos povos indígenas (Langdon, 2007). Quando se focalizam as práticas de autoatenção à gestação, ao parto e ao pós-parto realizadas por mulheres e homens Munduruku, vem à tona um conjunto de saberes que dificilmente os profissionais da saúde biomédicos compreenderiam como eficaz no cuidado com a saúde, ainda que tais práticas cumpram um papel inquestionável, do ponto de vista dos indígenas, para o bem-estar na produção de pessoas. E isso, em parte, resulta da imagem caricatural de uma medicina tradicional indígena universal. Imagem que desconhece as especificidades locais porque parte de uma 
postura cientificista e biologista, que embasa a forma de atenção biomédica à saúde e às enfermidades (Langdon, 2007).

A atribuição de determinadas características à forma de atenção biomédica - como eficácia pragmática, orientação curativa, relação médico-paciente assimétrica e subordinada, exclusão do saber do paciente, profissionalização formalizada, biologismo, associabilidade, a-historicidade, aculturalismo, individualismo, identificação ideológica com a racionalidade científica, saúde-enfermidade como mercadoria, tendência à medicalização dos problemas e à separação entre teoria e prática - permite caracterizar o "modelo médico hegemônico (MMH)" (Menéndez, 2005: 47). ${ }^{2}$

Se por um lado a Política Nacional de Atenção à Saúde dos Povos Indígenas (Pnaspi) prevê em seu escopo uma atenção diferenciada, sensível às "especificidades culturais, epidemiológicas e operacionais desses povos" (Brasil, 2002a: 7), por outro a biomedicina alopática está em um processo contínuo de expansão mundial. ${ }^{3}$ Isso resultaria em uma tensão entre princípios e projetos aparentemente contraditórios, mas com efeitos singulares nos contextos de pluralidade médica. Às políticas públicas de Estado de reconhecimento, valorização e integração dos saberes indígenas nos serviços de saúde sobrepõe-se a racionalidade do modelo médico hegemônico, no qual se propõe selecionar, avaliar, validar e capacitar, por exemplo, os praticantes indígenas conforme uma orientação marcadamente biologista de caráter e pretensão universalista. Isso produz uma relação de subalternização e desvalorização de alguns saberes indígenas e seus praticantes em detrimento de outros saberes, em consequência da identificação via uma aproximação pelas categorias similares àquelas praticadas e reconhecidas pela biomedicina (Langdon, 2013; Sesia, 1996). Em termos práticos, isso significa a promoção de uma imagem genérica e reducionista dos especialistas indígenas, como, por exemplo, pajé ou parteira, em consequência da operação lógica de equivalência errônea entre categorias distintas, mas pensadas como similares pelos gestores de políticas públicas e pelos profissionais da saúde biomédicos. Langdon $(2007,2013)$ sublinhou que o equívoco de considerar o pajé como um tipo de médico e a parteira como um tipo de obstetra, frequente nas iniciativas das políticas de Estado, se pautaria em uma concepção limitada da medicina tradicional indígena desconhecedora da pluralidade étnica e cultural dos povos indígenas no Brasil e da diversidade de especialista indígenas e mesmo das práticas xamânicas e dos pajés. Ao que tudo indica, isso também ocorre em outros países, como no México. Sesia (1996) assinalou que as iniciativas do governo mexicano de capacitar parteiras acabaram, ao fim, por reforçar e promover o modelo de atenção biomédico, pois os cursos oferecidos desconheciam e ignoravam os saberes específicos dessas especialistas.

Entre os Munduruku, identificamos a atuação de uma diversidade de especialistas indígenas cujas práticas, de modo algum, podem ser reduzidas a competências específicas (Scopel, Dias-Scopel G Wiik, 2012). Notamos mesmo que 
os saberes relativos a "pegar criança", isto é, sobre partejar, não estão restritos às práticas das parteiras. Como pretendo demonstrar neste trabalho, os partos que aconteceram durante o período de minha pesquisa de campo foram feitos, em geral, por mulheres mais velhas da família extensa. Embora haja atualmente parteiras na Terra Indígena Kwatá-Laranjal (TIKL), seria um equívoco supor que a prática de partejar fosse restrita a essas especialistas. Ao contrário, meus dados indicam que "pegar criança", "puxar a mãe do corpo" e "pegar barriga", saberes centrais nas formas de atenção indígena à gestação, ao parto, ao pós-parto e à saúde da mulher de modo geral, estavam diluídos na sociedade munduruku, e não limitados à atuação de especialistas. Em síntese, parteira, no contexto da TIKL, emerge como categoria social cuja definição genérica e universal não contempla a diversidade de práticas associadas aos cuidados com a gestação, o parto e o pós-parto, nem mesmo a heterogeneidade de praticantes indígenas envolvidos no processo de nascimento.

A Pnaspi reconhece a diversidade social e cultural dos povos indígenas e recomenda a articulação com "sistemas tradicionais de saúde", mas o modelo médico hegemônico sustenta sua crescente expansão na reprodução de relações sociais de hegemonia e subalternidade (Brasil, 2002a: 13, 17-18). Embora a Pnaspi tenha a articulação como diretriz, a qual pressupõe o reconhecimento e o respeito aos saberes indígenas e às iniciativas de ações nos serviços de saúde que se somem a esses saberes sem a eles se sobrepor, o que se verificou nas políticas de Estado foram diferentes tentativas de integração. Segundo Langdon (2007, 2013), tais políticas de integração dos saberes indígenas e seus praticantes redundaram em equívocos, reforçando a emergência de categorias sociais e reproduzindo a hegemonia da biomedicina, ${ }^{4}$ uma vez que para integrar era preciso capacitar ou produzir evidências científicas que fundamentassem a legitimidade e a prática segura dos especialistas e seus saberes segundo o paradigma biomédico (Dias-Scopel, Langdon G Scopel, 2007; Diehl, Dias-Scopel G Langdon, 2012; Ferreira, 2013; Langdon, 2013; Pérez-Gil, 2007a). Em síntese, à diretriz da atenção diferenciada preconizada na Pnaspi (Brasil, 2002a) sobrepõe-se o crescente movimento de expansão mundial da biomedicina alopática e, consequentemente, da medicalização da saúde.

Esse processo de expansão biomédica verifica-se, por exemplo, nas políticas de saúde reprodutiva no Brasil e mundo afora. No Brasil, por exemplo, em 2004 o Ministério da Saúde lançou um plano de ação para a execução da Política Nacional de Atenção Integral à Saúde da Mulher para o período de 2004-2007, com o objetivo de ampliar o acesso aos serviços de saúde, a humanização e melhoria na qualidade desses serviços a "segmentos sociais excluídos da atenção, no que se refere às suas especificidades" (Brasil, 2004a: 6). A mulher indígena aparece como um desses segmentos, ao qual se propõe melhorar as condições de vida e saúde por meio da ampliação dos serviços de atenção integral à saúde em 100\% dos polos-base, da 
capacitação dos profissionais da saúde que atuam nos Distritos Sanitários Especiais Indígenas (DSEIs) e no treinamento de parteiras indígenas (Brasil, 2004a: 43).

Outro exemplo seria o plano de ação especial para reduzir a mortalidade infantil e materna e ampliar as ações de atenção básica entre as populações indígenas, lançado pelo Ministério da Saúde em 2012. ${ }^{5}$ Para isso, foi instituído o Comitê de Gestão Integrada das Ações de Atenção à Saúde e Segurança Alimentar dos Povos Indígenas, coordenado pelo Ministério da Saúde, mas que integrava ações de outros ministérios, entre eles o Ministério da Defesa, o Ministério da Justiça/Fundação Nacional do Índio (Funai), o Ministério do Desenvolvimento Agrário e o Ministério do Desenvolvimento Social e Combate à Fome. Segundo o Plano, 16 DSEIs seriam selecionados em todo o Brasil para a execução imediata das ações de ampliação de cobertura vacinal, de vigilância nutricional e suplementação alimentar, de incentivo ao aleitamento materno, além da realização de exames sorológicos (HIV, sífilis, hepatites B e C), acompanhamento de pré-natais, identificação e monitoramento dos casos de gravidez de alto risco e articulação com a rede municipal e estadual de saúde para atendimento dos casos de média e alta complexidades. A intenção expressa era que esses serviços, em sua maioria de prática biomédica, fossem promovidos em todos os 34 DSEIs, ao longo do tempo. Ambas as iniciativas previam ações integradas com outros ministérios do governo federal e com secretarias municipais e estaduais para ampliar a cobertura da atenção primária biomédica às populações indígenas.

Infelizmente, no que se refere às ações executadas e aos resultados alcançados, ainda pesam as dificuldades na notificação dos dados. Em novembro de 2013, a Secretaria Especial de Saúde Indígena (Sesai), órgão do Ministério da Saúde responsável pela gestão da saúde aos povos indígenas no Brasil desde 2010, promoveu com a Secretaria de Vigilância em Saúde (SVS) um encontro para institucionalizar a vigilância de óbitos maternos e infantis. 6 O encontro teve por objetivo alertar sobre a importância do registro da causa da morte para adequar as estratégias de redução das taxas de mortalidade materna e infantil, que apresentam índices superiores às médias nacionais, segundo os gestores da SVS. Entre as estratégias apresentadas destacaram-se as propostas de intensificação da vigilância epidemiológica e de informação, de implantação de sistemas informatizados e de integração da atuação dos setores de saúde indígena, em suma, a discussão e aprimoramento do processo processo de registro e fluxo dos dados.

Toda política pública de saúde envolve a ideia de que o maior controle das informações é central na definição das estratégias de ações locais. Entretanto, apresentamos recentemente um trabalho sobre o fluxo de dados acerca dos programas de controle de hipertensão, diabetes e vigilância alimentar e nutricional em crianças nos polos-base da TIKL no qual se evidenciaram algumas descontinuidades e contradições da medicalização no contexto indígena (Scopel G Dias-Scopel, 2010; Scopel, Dias-Scopel G Diehl, 2010). A produção e o fluxo dos dados, ao invés de gerar 
informação epidemiológica sobre a situação para nortear o planejamento das ações, foram reduzidos a um controle sobre o trabalhador/indivíduo e sobre as ações dos profissionais da saúde. Além disso, havia descontinuidade dos dados entre os níveis locais e o nível da gestão do DSEI, isto é, os profissionais que atuavam nas aldeias reclamavam da falta de retorno das análises epidemiológicas sobre os dados consolidados mensalmente. Esse é um fato que transpassa outros contextos indígenas (Dias-Scopel, Langdon G Scopel, 2007; Diehl, Dias-Scopel G Langdon, 2012; Scopel, Dias-Scopel G Diehl, 2010; Scopel G Dias-Scopel, 2010). Os problemas envolvidos no registro e fluxo dos dados podem gerar uma situação difícil para o planejamento das ações, especialmente se levarmos em consideração a grande rotatividade de profissionais da saúde nas Equipes Multiprofissionais de Saúde Indígena (EMSIs) e o nível de gestão dos DSEIs (Diehl, Dias-Scopel G Langdon, 2012).

Nesse cenário de subnotificação, falhas nos fluxos de dados e alta rotatividade dos profissionais da EMSI, extensivo ao contexto da TIKL, os agentes indígenas de saúde (AISs), os agentes de saneamento e os agentes microscopistas Munduruku tiveram atuação importante nas ações de atenção básica. Na TIKL, por exemplo, $52 \%$ dos AISs que estavam trabalhando durante o período da pesquisa de campo já atuavam no cargo havia mais de dez anos. Esses AISs, consequentemente, tinham longa experiência de trabalho na EMSI e haviam acumulado saberes e habilidade em procedimentos biomédicos como pesar, aferir pressão, fazer sutura, aplicar injeções (embora esta tarefa tenha sido retirada do conjunto de atividades que realizavam), usar o termômetro, além de preencher uma série de formulários com dados relativos aos programas controlados por eles nas aldeias (como, por exemplo, controle de hipertensão e diabetes, e pesagem das crianças). E embora os AISs não fossem expertos nos saberes indígenas para enfrentamento dos processos de saúde-enfermidade-atenção, também incluíram em suas práticas cotidianas indicação de remédios caseiros e de especialistas indígenas.

Entretanto, verifica-se uma gradativa e contínua expansão da medicalização da saúde indígena e dos cuidados com a gestação, o parto e o pós-parto, como veremos ao longo deste trabalho, no contexto da TIKL. Entendo que é importante considerar os processos de indigenização da biomedicina como forma efetiva de articulação de saberes (Sahlins, 2007), porém, sem minimizar o crescente processo de medicalização da gestação, do parto e do pós-parto no campo da saúde indígena. ${ }^{7}$

Como veremos, os Munduruku têm articulado as formas de atenção indígena e biomédica no nível das práticas de autoatenção relativas à gestação, ao parto e ao pós-parto. As mulheres indígenas fazem uso de "banhos", "pegam barriga", "puxam a mãe do corpo", seguem dietas alimentares e junto com seus maridos cumprem prescrições sobre determinadas atividades físicas, entre outras práticas articuladas ao acompanhamento pré-natal feito no polo-base, com a enfermeira, ou exames laboratoriais realizados nas unidades do SUS. Além disso, os 
partos ocorrem tanto na aldeia como no hospital da cidade mais próxima da TIKL. Essa articulação entre saberes - indígenas e biomédicos - acomoda diferentes conhecimentos sobre a fisiologia e anatomia da gestação, do parto e do pós-parto, sobre concepção e formação do corpo, sobre prevenção e manutenção da saúde ou tratamento de determinadas enfermidades e sobre reprodução, entre muitos outros aspectos. Além disso, acomoda também paralelos entre a racionalidade terapêutica indígena e a biomédica, como, por exemplo, o reconhecimento do efeito iatrogênico dos medicamentos, a importância dada à alimentação e um ideal de minimização de riscos e de estados de vulnerabilidade.

O nascimento de uma criança, para os Munduruku, mobiliza uma diversidade de atores sociais envolvidos em esforços coletivos e individuais na expectativa de garantir e manter o bem-estar da criança e igualmente da mãe e do pai. O nascimento de uma criança é mais bem compreendido como processo que abarca um conjunto de ações e relações sociais orquestradas durante a gestação, o parto e o pós-parto. 8 O sentido "visado" (Weber, 2009: 16) que emerge nas relações sociais por ocasião do nascimento de uma criança é atravessado por motivações estreitamente relacionadas com o bem-estar da família, e não apenas do indivíduo, seja este a criança, a mãe ou o pai, com a produção de pessoas hábeis socialmente e com a modelação do corpo desejável; em síntese, com a produção e manutenção da sociabilidade munduruku. Se por um lado as expectativas que orientam os atores sociais mobilizando seu engajamento em relações sociais ao longo do processo de nascimento permitem enfatizar alguns elementos que compõem a estrutura social, por outro inflectem também as estruturas da situação ou do campo de ação em que se movem. Nesse sentido, é importante ter em mente o contexto de pluralidade de formas de atenção à saúde e a enfermidades com o qual conviviam os Munduruku da TIKL. Havia os serviços de saúde biomédicos, ofertados pela Sesai e pelo Sistema Único de Saúde (SUS), que constituíam uma das formas de atenção às enfermidades, juntamente com as formas de autoatenção, as formas de atenção indígena (pegadores de desmentidura e de rasgadura, benzedores, parteiras), xamânicas (pajés, espiritistas, remédios caseiros) e religiosas (Scopel, Dias-Scopel G Wiik, 2012; Scopel, 2013).

A análise das práticas de autoatenção relativas à gestação, ao parto e ao pós-parto realizadas por mulheres e homens Munduruku permitiu focalizar o nascimento como um processo de reprodução biossocial de novos membros na família elementar, de laços afetivos entre os membros da família extensa, da sociedade munduruku, assim como dos próprios saberes sobre concepção, fisiologia, anatomia e comportamentos adequados à gestação, ao parto e ao pós-parto. Ainda mais, a análise das práticas de autoatenção relativas a esse processo expôs que as mulheres Munduruku vêm articulando os saberes indígenas com os saberes biomédicos. Assim, parece razoável problematizar o modo como os Munduruku têm articulado práticas 
indígenas e práticas biomédicas no trato com a gestação, o parto e o pós-parto, e refletir sobre as dinâmicas, relações sociais e ideologias que nesse contexto de pluralidade médica são (re)criadas, mantidas e transformadas a partir da interação interétnica. Cabe perguntar igualmente como a proposta de uma atenção diferenciada pode contemplar os saberes indígenas e seus praticantes sem que, para isso, precise validá-los ou capacitá-los segundo uma racionalidade biomédica.

\section{Atenção diferenciada e o índio hiper-real}

No contexto da saúde indígena no Brasil, desde a I Conferência Nacional de Saúde Indígena, em 1986, já se falava da importância da atenção diferenciada para melhorar a qualidade e eficácia dos serviços biomédicos ofertados a essa população. Na época, o Brasil passava por um período de redemocratização e de reforma sanitária em que muitos segmentos da sociedade civil organizada se reuniram para propor e fazer incorporar suas demandas na Constituição de 1988. Ramos (1995) registra a importância do movimento indígena e a extensiva participação de lideranças indígenas associadas a antropólogos, jornalistas, missionários, indigenistas, entre outros, nesse processo. A Constituição definiu os princípios de acesso universal e igualitário aos serviços do SUS e a descentralização, o atendimento integral e a participação comunitária como diretrizes da organização dos serviços (Brasil, 1988, Seção II, Da Saúde). A Carta garante aos índios o direito à sua organização social, aos costumes, às línguas, crenças, tradições e às terras tradicionalmente ocupadas (Brasil, 1988, Capítulo VIII - Dos Índios). Destaca ainda, no Capítulo II, o direito ao trabalho, ao lazer, à saúde, à educação, à alimentação, à maternidade e infância e à proteção, entre outros direitos sociais. Com a criação do SUS, em 1990, ampliou-se a cobertura dos serviços de saúde para a população brasileira, e com a criação do Subsistema de Atenção à Saúde Indígena (Sasi), em 1999, foi garantido ao indígena um modelo diferenciado e global de atenção à saúde como parte da rede do SUS. ${ }^{9}$

De 1999 até 2010, quando as ações passaram da gestão da Fundação Nacional de Saúde (Funasa) para a Sesai, no interior do Ministério da Saúde, o Sasi passou por diversas reformulações quanto à definição dos órgãos competentes e de suas atribuições para a promoção da saúde dos povos indígenas. ${ }^{10}$ Todavia, os princípios aprovados na Pnaspi ainda figuram como diretrizes para a promoção das ações de atenção à saúde, com foco na participação comunitária nas atividades de planejamento, execução e controle dos serviços. No tocante à promoção de uma atenção diferenciada, destaca-se que

O reconhecimento da diversidade social e cultural dos povos indígenas,

a consideração e o respeito dos seus sistemas tradicionais de saúde são 
imprescindíveis para a execução de ações e projetos de saúde e para a elaboração de propostas de prevenção/promoção e educação para a saúde adequadas ao contexto local. O princípio que permeia todas as diretrizes da Política Nacional de Atenção à Saúde dos Povos Indígenas é o respeito às concepções, valores e práticas relativos ao processo saúde-doença próprios a cada sociedade indígena e a seus diversos especialistas. A articulação com esses saberes e práticas deve ser estimulada para a obtenção da melhoria do estado de saúde dos povos indígenas. (Brasil, 2002a: 17-18)

Após mais de uma década da aprovação da Pnaspi, a demanda por atenção diferenciada ainda consta da pauta de reivindicações dos povos indígenas no Brasil. A convocação da V Conferência Nacional de Saúde Indígena, por exemplo, foi aprovada com o seguinte título: "Subsistema de Atenção à Saúde Indígena e SUS: direito, acesso, diversidade e atenção diferenciada". No documento que visa a orientar as pautas de discussão da V Conferência Nacional, realizada em dezembro de 2013, destacam-se as ações de saúde voltadas para a criança e a mulher indígenas.

Langdon (2013) citou algumas dificuldades subjacentes à implementação de uma atenção diferenciada à saúde dos povos indígenas no Brasil. A autora destacou as diferenças ideológicas que embasam as noções de integração e de articulação e citou a falta de entendimento por parte dos gestores e profissionais da saúde sobre o que seria e como promover uma atenção diferenciada. A noção de articulação supõe diálogo entre os atores envolvidos. Todavia, há algumas dificuldades na construção desse diálogo devido à projeção de imagens holográficas ou hiper-reais dos índios (Ramos, 1995). Ramos analisou a relação interétnica entre índios e indigenistas profissionais de instituições privadas e das ONGs e concluiu que os profissionais brancos projetavam um simulacro da ética branca, por forjarem a imagem de um índio modelo/modelo de índio, um índio hiper-real com qualidades, valores, padrões éticos e estéticos ao construírem seus objetos de política: a defesa dos direitos indígenas. Sugiro que as ideias de imagem holográfica e índio hiper-real podem ventilar as análises no campo da saúde indígena, uma vez que também os gestores e profissionais da saúde parecem atuar com base na imagem de um índio modelo/modelo de índio e sua "medicina tradicional". Ao índio hiper-real contrapõe-se o "índio de verdade" e sua alteridade irredutível às essencializações singulares e homogeneizantes.

Assim, a permanência da temática da atenção diferenciada nos debates nacionais sobre a questão da saúde indígena e as considerações de Langdon (2013) parecem indicar a importância de tomá-la não como fato social dado a priori, mas como noção em processo de construção capaz de produzir um marco social, ideológico, legal e institucional nas políticas públicas de saúde para os povos indígenas com e contra a tendência homogeneizadora do Estado. Por um lado, a noção de atenção diferenciada pode ser observada como projeto do movimento indígena e sua 
implementação como ato político importante para o reconhecimento da diversidade e das especificidades culturais desses povos e para evidenciar as experiências históricas vividas como realidades de exploração econômica e marginalização social. Por outro lado, é possível também identificar as matrizes ideológicas de políticas internacionais, ratificadas pelo Estado brasileiro, na configuração de políticas nacionais de saúde pública como, por exemplo, a Pnaspi, conforme observou Ferreira (2013). Ao mesmo tempo que há um esforço para lutar contra as imagens que as políticas de Estado se esforçam para impor ao "tradicional", coexiste a necessidade de lutar contra a invisibilidade cultural, social e sanitária dos povos indígenas, especialmente nos contextos de grande proximidade dos centros urbanos e na região Norte do Brasil.

Tal invisibilidade se estende também sobre a falta de dados epidemiológicos e antropológicos sobre a saúde da mulher indígena no Brasil, que possam subsidiar o planejamento de ações de saúde de forma adequada às especificidades locais (Coimbra Jr. G Garnelo, 2004; Pérez-Gil, 2007a; Ferreira, 2013). Isso se torna uma questão relevante, uma vez que o SUS e a Sesai definem o levantamento epidemiológico como base para a promoção de estratégias adequadas e ações racionalizadas de intervenção em saúde. Segundo o Inquérito Nacional de Saúde e Nutrição dos Povos Indígenas (INSNPI), a situação de saúde das mulheres e crianças indígenas é pior do que as registradas para a população não indígena, e ainda mais críticas nas aldeias localizadas na região Norte (Coimbra Jr. et al., 2009). ${ }^{11}$ Isso apareceu nos dados analisados; por exemplo, os dados referentes ao número de consultas realizadas durante o pré-natal e aos tipos de exame solicitados revelaram o baixo percentual e até a ausência de consultas e de sorologia das principais infecções, como a normalmente feita para detectar sífilis. Além disso, os dados também revelam subnotificação e problemas no registro das ações, que podem ter impacto sobre as análises feitas. Ainda assim, com base nos dados obtidos e analisados, verificou-se a baixa cobertura dos serviços de saúde, além da baixa qualidade dos serviços de atenção ao pré-natal para as populações indígenas, e isso incluía a falta de registro das ações e procedimentos realizados. Os autores concluíram:

Assim, mostra-se necessário investimentos na qualificação profissional para um acompanhamento obstétrico e materno-infantil satisfatório, a fim de se promover a equidade entre indígenas e não indígenas e de perseguir o objetivo primordial da atenção pré-natal: o nascimento de uma criança saudável e o bem-estar materno e neonatal. (Coimbra Jr. et al., 2009: 203)

É necessário ressaltar que a efetividade das ações biomédicas não resulta somente da qualificação profissional ou da expansão da cobertura dos serviços de atenção à saúde ou ainda de formas mais competentes de produção e controle das informações e dos dados epidemiológicos. 
Neste trabalho, inspirado pelas reflexões de Boccara (2012), sugiro que a atenção diferenciada não seja apenas uma noção, mas um campo social e simbólico orquestrado por diferentes atores com interesses e entendimentos igualmente diversos envolvidos na promoção da saúde dos povos indígenas. ${ }^{12}$ Pesquisas recentes ainda demonstram que não há um significado fixo, evidente, nem mesmo compartilhado acerca da noção de atenção diferenciada (Dias-Scopel, Langdon G Scopel, 2007; Diehl, Dias-Scopel G Langdon, 2012; Langdon, 2013). Trata-se antes de um campo social em formação, não de um conceito apenas. Nesse processo de construção do campo da atenção diferenciada, podemos assumir que "saberes culturais constituem não apenas explanações e significados, mas também ideologias por meio das quais certas realidades políticas e econômicas são legitimadas" (Comaroff, 2013: 22, tradução minha).

Nesse sentido, a abordagem antropológica tem muito a contribuir, pois há muito já evidenciou que os saberes e as práticas relativas à gestação, ao parto e ao pós-parto são eventos marcados culturalmente, carregados por uma dimensão simbólica. Desde o início do século XX, com os trabalhos de Van Gennep (1978) e Mauss (2003a), sabemos que a noção de corpo varia historicamente e de sociedade para sociedade. Esses autores ensinaram que o corpo emerge, na antropologia, como categoria analítica, portanto socialmente construída. De modo semelhante, os estudos de etnologia indígena das terras baixas sul-americanas, desde a década de 1970, advertem para o investimento na construção da pessoa e fabricação dos corpos como uma singularidade que transpassa a diversidade linguística, social e cultural das populações indígenas sul-americanas, embora realizados por mecanismos e arranjos sociais que demarcam universos e convenções simbolicamente diversos (Seeger, Da Matta G Viveiros de Castro, 1979).

Recentemente, alguns autores têm afirmado que as formas de produção de corpos e pessoas entre as populações indígenas amazônicas inscrevem-se nas relações de parentesco e de gênero (Belaunde, 2005, 2006; Conklin, 2001; McCallum, 1999, 2001; Viegas, 2003; Tassinari, 2007; Overing, 1999; Rosengren, 2006). Em geral, esses estudos contribuem para o exercício de estranhar as nossas próprias noções de corpo, pessoa, gênero, família, saúde, doença, morte etc. Um estranhamento salutar na busca do diálogo interétnico.

Espero que este livro contribua com uma etnografia sobre a forma como os Munduruku vivenciam atualmente o nascimento de um novo ser, com foco nas práticas de autoatenção relativas à gestação, ao parto e ao pós-parto, e para um debate crítico sobre a atenção diferenciada às populações indígenas no Brasil. 
1 O conceito de formas de autoatenção, proposto por Menéndez (2003, 2005, 2009), se insere no debate da antropologia dedicado ao estudo dos processos de saúde-enfermidade-atenção em contextos de pluralidade médica. $\mathrm{O}$ autor propõe que as pesquisas deveriam focalizar os saberes de pessoas leigas, uma vez que, em geral, os estudos conduzidos a partir dos saberes de especialistas tendem a destacar muito mais as divergências e os antagonismos do que as articulações entre as diferentes formas de atenção à saúde.

2 Conforme assinala o próprio Menéndez, por ser um modelo, isto é, uma abstração feita com intenção heurística, essa caracterização corresponde apenas parcialmente à realidade: "o manejo de modelos como o de tipos ideais deve assumir desde o princípio que o tipo e o modelo não equivalem à 'realidade' que querem descrever e explicar, mas são construções baseadas na realidade" (Menéndez, 2011: 37, tradução minha). Entretanto, ainda assim a definição de modelo médico hegemônico permite identificar alguns elementos norteadores na forma de atenção biomédica alopática com a qual os indígenas têm contato por intermédio dos serviços de atenção primária gerida pela Secretaria de Atenção Básica à Saúde Indígena (Sasi) no Brasil, como nas ações de controle e acompanhamento pré-natal ou de planejamento familiar, nos serviços prestados no âmbito da atenção secundária e terciária da rede municipal do Sistema Único de Saúde (SUS) (Diehl, Dias-Scopel G Langdon, 2012; Garnelo, 2003, 2012; Langdon et al., 2006; Scopel, 2013; Ferreira, 2013).

3 A Política Nacional de Atenção à Saúde dos Povos Indígenas foi aprovada pela portaria do Ministério da Saúde n. 254, de 31 de janeiro de 2002.

4 Há estudos sobre a expansão do modelo biomédico de atenção ao parto realizados em diferentes países. O estudo de Sargent e Bascope (1996) é dedicado aos conhecimentos relacionados ao parto feito no México, nos Estados Unidos e na Jamaica, cada qual caracterizado pelo acesso ou não à alta tecnologia obstétrica e hospitalar. Fiedler (1996) discutiu as mudanças nos conhecimentos e representações sobre o parto no Japão e a interação entre parteiras e obstetras no contexto hospitalar. No Brasil, há ainda a dissertação de Giberti (2013) sobre o processo de nascimento entre os Pankararu, Pernambuco, na qual a autora destacou uma articulação entre os conhecimentos indígenas e biomédicos sobre gestação e parto. Cito também o trabalho de Tornquist (2004), que analisou a complexidade do processo de medicalização do parto no Brasil e destacou as similaridades com o movimento mundial de expansão da forma biomédica de assistência ao parto e as especificidades nacionais e regionais de institucionalização do parto hospitalar ao estudar as iniciativas do movimento pela humanização do parto e nascimento.

5 Conforme site do Ministério da Saúde: < http://portal.saude.gov.br/portal/saude/gestor/area. cfm?id_area $=1862>$. Acesso em: 26 nov. 2013.

6 Conforme site do Ministério da Saúde: < http://portal.saude.gov.br/portal/saude/gestor/visualizar_texto.cfm?idtxt $=44217>$. Acesso em: 24 nov. 2013.

7 A proposta de Sahlins permite uma explicação alternativa sobre os arranjos culturais em suas especificidades locais em relação às análises de processos de hegemonia/subalternidade ou resistência em um mundo cada vez mais globalizado, interconectado, de economia capitalista e expansão biomédica. Conforme Sahlins (1997a, 1997b, 2007), os processos de "indigenização" exemplificam a agência das populações indígenas nos processos de expansão das fronteiras 
capitalistas de modo a prover o próprio desenvolvimento, otimizando as próprias dinâmicas socioculturais e políticas, em conformidade com um ideal próprio de boa vida e bem-estar. No campo específico da saúde indígena, podemos pensar que esses processos promoveram práticas de "intermedicalidade". Greene (1998) utiliza a noção de intermedicalidade para se referir à incorporação de recursos biomédicos como penicilina, aspirina e outros elementos não indígenas como gasolina, por exemplo, feita pelos xamãs peruanos em suas práticas xamânicas, que, ao final, cooperavam para inspirar o poder deles. Estudos feitos entre populações indígenas no Brasil também têm utilizado a proposição de Sahlins sobre indigenização para enfatizar o complexo fluxo de bens, informações e trocas entre o nível local, da aldeia, e o nível nacional e internacional, com foco especial nos espaços de produção das políticas públicas de saúde (Garnelo, 2003; Scopel, 2007; Ferreira, 2013).

8 Estou trabalhando com a noção de relação social definida por Max Weber: "Por 'relação' social entendemos o comportamento reciprocamente referido quanto a seu conteúdo de sentido por uma pluralidade de agentes e que se orienta por essa referência. A relação social consiste, portanto, completa e exclusivamente na probabilidade de que se aja socialmente numa forma indicável (pelo sentido), não importando, porquanto, em que se baseia essa probabilidade" (Weber, 2009: 16). Destaco dessa definição a ideia de que a relação social não é algo em si, mas um comportamento, uma ação realizada por agentes e orientada por um sentido "visado". O autor utiliza a noção de sentido "visado", distinto do sentido "normativamente 'correto' ou metafisicamente 'verdadeiro'", a fim de destacar que os agentes agem orientados pelas ações de outros agentes e que todos estão reciprocamente referidos a um sentido subjetivamente visado. O que não significa, necessariamente, que o sentido que permeia a relação social seja o mesmo para todos os agentes envolvidos.

9 O Subsistema de Atenção à Saúde Indígena (Sasi) é instituído pela lei n. 9.836, de 23 de setembro de 1999, que acrescenta dispositivos à lei n. 8.080, de 19 de setembro de 1990, e dispõe sobre as condições para a promoção, proteção e recuperação da saúde, a organização e o funcionamento dos serviços correspondentes e dá outras providências.

10 A Secretaria Especial de Saúde Indígena (Sesai) foi criada inicialmente pelo decreto n. 7.336, de 19 de outubro de 2010. Este foi revogado pelo decreto n. 7.530, de 2011, o qual, por sua vez, foi também revogado pelo decreto n. 7.797, de 2012, sendo novamente revogado pelo decreto n. 8.065, de 7 de agosto de 2013, atualmente em vigor.

11 Esse inquérito foi o primeiro levantamento nacional sobre as condições de saúde e nutrição dos povos indígenas no Brasil, resultado de um projeto da Funasa financiado pelo Banco Mundial e executado por pesquisadores de diversas instituições sob a coordenação geral do pesquisador Carlos Coimbra Jr., da Fundação Oswaldo Cruz (Fiocruz).

12 Boccara (2012) faz uma revisão do conceito de interculturalidade, no Chile. Com base em uma análise histórica dos usos desse conceito, situa os diferentes contextos e atores que têm utilizado a noção de interculturalidade e demonstra um deslocamento de seu sentido original: utilizado a princípio pelo movimento indígena como forma de luta política, marcadamente subversiva, o termo foi posteriormente apropriado pelo Estado chileno em sua "retórica neoindigenista". O autor conclui que a noção de interculturalidade está em processo de construção e se caracteriza como campo social no qual atores, com diferentes posições de poder e interesses, manejam lutas de classificação "que resultam na definição do que é a cultura indígena legítima". Minha sugestão é que é possível observar um processo semelhante ao redor da noção de atenção diferenciada no Brasil. 


\section{A Pesquisa de Campo, a Metodologia e a Contextualização Histórica}

Esta etnografia é resultado do trabalho de campo realizado entre os índios Munduruku que habitam a Terra Indígena Kwatá-Laranjal (TIKL). A TIKL está localizada na região Norte do Brasil, no município de Borba, estado do Amazonas, situada a sudoeste da foz do rio Madeira. ${ }^{13} \mathrm{O}$ rio Madeira é um dos maiores tributários do rio Amazonas e sua navegação liga o estado amazonense ao estado de Rondônia. Há um intenso fluxo de pessoas e mercadoria navegando pelo rio.

A TIKL localiza-se nas terras à margem direita do rio Madeira. Abrange dois grandes rios: o Mari-Mari, que nasce na terra indígena e deságua no Abacaxis, e o Canumã, afluente do Madeira, que atravessa de norte a sul a TIKL. Em 2012 eram, ao todo, 33 aldeias na TIKL, das quais 21 estavam situadas às margens do rio Canumã e 12 às margens e afluentes do rio Mari-Mari. Cada aldeia tinha uma liderança local (cacique), em sua maioria exercida por homens, eleitos pela comunidade. Em cada rio havia uma liderança que representava todas as aldeias. Segundo o cacique do rio Canumã, Manoel Cardoso Munduruku, trata-se de posição ocupada exclusivamente por homens e transmitida por herança patrilinear. Os Munduruku da TIKL viviam em aldeias cuja população variava de 26 a 592 indígenas, somando um total de 2.500 indígenas. ${ }^{14}$ Todos falavam português e apenas alguns idosos a língua munduruku, do tronco linguístico tupi. ${ }^{15}$ Apresento um mapa da TIKL para que o leitor tenha uma ideia da disposição das aldeias ao longo dos dois rios (Figura 1).

A pesquisa de campo etnográfica foi realizada em três etapas. A primeira foi entre janeiro e fevereiro de 2009; a seguinte, de agosto a dezembro de 2010; a última, entre março e junho de 2011. O tempo de permanência na TIKL somou aproximadamente oito meses. Todo o trabalho de campo foi conduzido em companhia de meu marido, Daniel Scopel, à época também doutorando no Programa de Pós-Graduação em Antropologia Social da Universidade Federal de Santa Catarina, no qual pesquisava práticas de atenção à saúde e xamanismo entre os Munduruku da TIKL. Eu estava grávida de três meses quando ingressei na terceira etapa da pesquisa de campo, e a partir daquele momento aprendi que não apenas a mulher, mas também o homem poderia sentir alguns sintomas relativos à gestação. $\mathrm{O}$ fato de eu estar grávida em campo e acompanhada de meu marido contribuiu para que 
eu pudesse compreender a amplitude e os significados das práticas de autoatenção relativas à gestação, conforme veremos a seguir.

Não é nenhuma novidade na antropologia que as condições social, etária

Figura 1 - Mapa da Terra Indígena Kwatá-Laranjal indicando aldeias

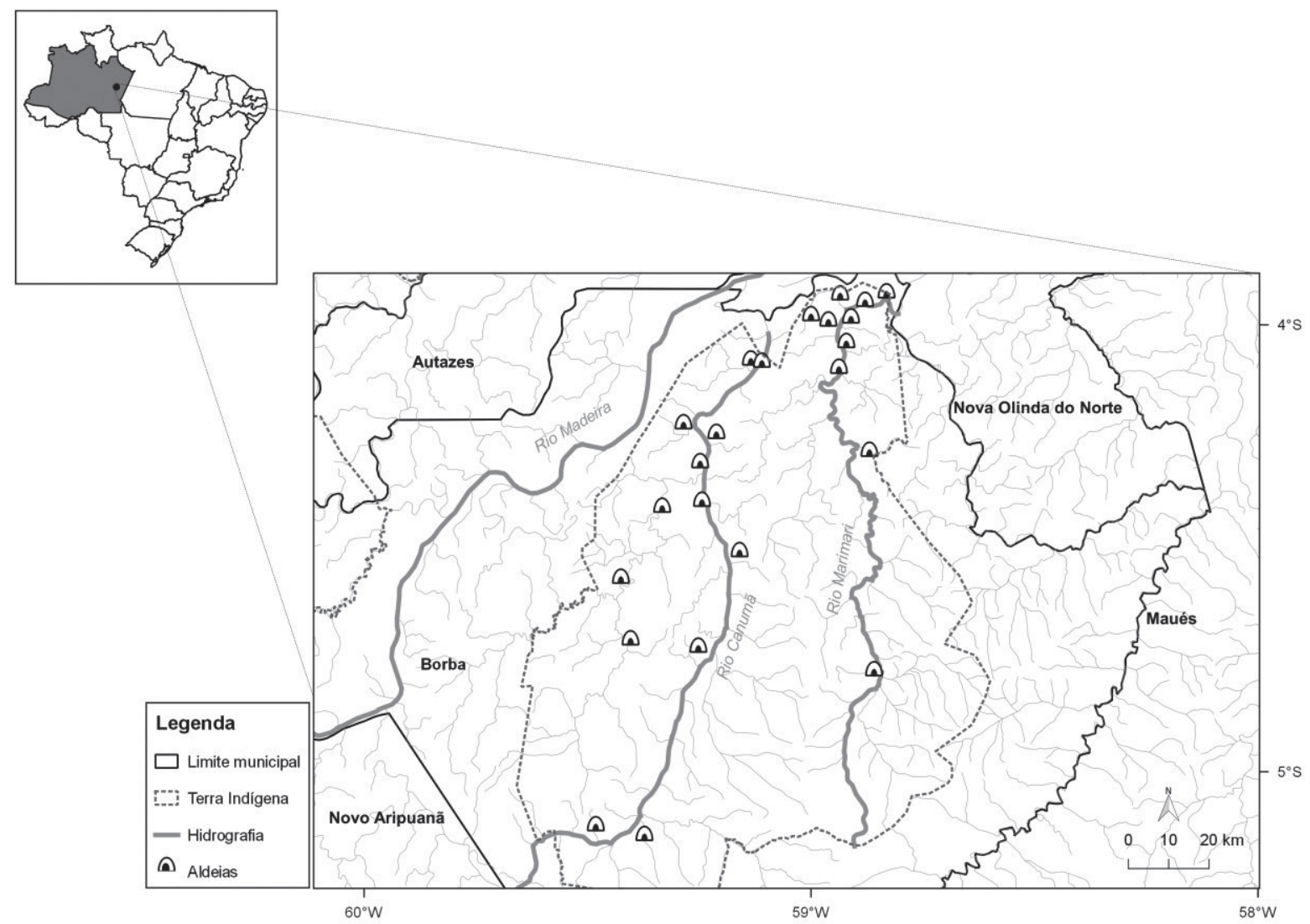

Fonte: produzido por D. Scopel e F. Fonseca a partir do Mapa de Demarcação Terra Indígena Kwatá-Laranjal (Funai, 2002).

e de gênero afetam a condução da pesquisa, ainda que este não seja um ponto de consenso. Não é estranho tampouco ao fazer antropológico que a ocorrência de certos eventos ao longo da pesquisa afete o pesquisador e promova mudanças em seu status e na própria pesquisa (Evans-Pritchard, 2005; Favret Saada, 2005; Geertz, 1989). É preciso reconhecer que minha situação e a de meu marido mudaram na terceira e última etapa da pesquisa de campo por conta da minha gestação. Do ponto de vista dos Munduruku, ambos ingressamos em um novo status social e corporal. Eles nos situaram em um novo estado do ser. Para aqueles com quem compartilhávamos a rotina da vida diária, tornamo-nos o foco da atenção em muitos momentos. Para aqueles com quem conversávamos quase diariamente, passamos 
a compartilhar experiências e sanar dúvidas. Parecia estranho aos Munduruku que um casal, junto há 15 anos, ainda não tivesse filhos.

O fato de eu estar grávida na terceira etapa da pesquisa de campo e trabalhando com um tema relativo a gestação, parto e pós-parto, ao fim acabou por otimizar a observação participante, promovendo um ganho qualitativo em minha relação com os Munduruku e com as questões que eu vinha investigando. Não é exagerado afirmar que essa nova condição dada pela gestação de meu primeiro filho conduziu a novos caminhos para a observação participante, por ter facilitado a compreensão dos significados simbólicos compartilhados e o ingresso no conjunto de práticas relativas à gestação e ao parto mobilizadas pelos Munduruku da TIKL, dos quais, muito superficialmente, eu vinha me aproximando, fosse pela observação participante na rotina de mulheres gestantes, fosse por via das conversas informais. Totalmente diferente da aproximação com o conjunto de práticas relativas ao resguardo do pós-parto que, desde o princípio do trabalho de campo, haviam sido facilmente observáveis. Esse era um tema frequentemente discutido entre os Munduruku. Cumpre destacar que, conforme apresento no Capítulo 2, os modos de aprender praticados pelas populações indígenas, em particular pelos Munduruku, são corporificados, isto é, realizados na prática diária. É no fazer que se aprendem determinados saberes, os quais incluem, por exemplo, a gestação. Eu fui aprendendo a ser gestante à medida que os Munduruku compartilhavam suas experiências e faziam sugestões, alertas e prescrições.

Na busca por demonstrar a diversidade de culturas humanas, os antropólogos têm lançado mão de categorias conceituais ou de discurso "ético", como diria Geertz (1997: 87) como ponto de partida de suas análises e descrições. Isso tem o efeito de alargar ou alterar as próprias noções que foram tomadas como ponto de partida para a reflexão antropológica. Muitos autores já afirmaram que as categorias ocidentais (de pessoa, corpo, parentesco, entre outras) não podem ser concebidas como naturais, dadas a priori, pois ocultariam o fato de serem culturalmente construídas (Hertz, 1980; Leenhardt, 1971; Mauss, 2003a, 2003b; Schneider, 1968, 2004). Sugiro que, do mesmo modo, as categorias de gestação, parto e pós-parto, não devam ser tomadas a priori como eventos fisiológicos e etapas de um processo apenas biológico (Van Gennep, 1978), pois isso encobriria a dimensão social, histórica e cultural constituidora daquilo que vem a ser a gestação, o parto e o pós-parto para os Munduruku. A distinção entre categorias éticas e êmicas (Geertz, 1997) possibilita, embora de maneira provisória e abstrata, uma aproximação dos conceitos próximos à experiência compartilhados pelos Munduruku e, principalmente, compreender e descrever as práticas manejadas por eles, as quais sublinham as especificidades da vivência local. Este ponto de partida é apenas uma estratégia do empreendimento antropológico que evocaria, assim, formas específicas de descrever a realidade e de atribuir-lhe um sentido que refletiria "práticas ocidentais de 
conhecimento" (Strathern, 2006: 21). É importante lembrar que um dos efeitos da autocrítica às categorias sociais utilizadas pelos antropólogos (cultura, sociedade, entre outras), em especial ao final da década de 1970, foi assumir que os "outros" são pensados nos termos de nossas categorias analíticas éticas, e que isso implicaria desdobramentos entre os constructos analíticos daqueles que a antropologia estuda e os constructos analíticos antropológicos, em que oscilariam também as imagens que o Ocidente cria sobre esses "outros" e os reflexos dessas imagens sobre si (Heckendeger, 2003; Keesing, 1994; Marcus G Fischer, 1999; Strathern, 2006; Wagner, 1981). Entretanto, é pertinente ponderar que a "alteridade radical" pode ser um artifício "inventado" pelo procedimento antropológico, que parte de certo "exagero" na comparação entre as categorias do pensamento ocidental e as categorias do pensamento daqueles que o antropólogo estuda. Esse exagero é o que Keesing (1994) chamou de invenção de uma "alteridade radical".

Na primeira etapa da pesquisa de campo, percorri algumas aldeias de ambos os rios que banham a TIKL a fim de assentar uma ideia panorâmica daquele contexto. Naquele momento, realizei as primeiras coletas de dados sobre a demografia, a epidemiologia e a organização dos serviços biomédicos de atenção primária à saúde ofertados no interior da TIKL. ${ }^{16}$ Após percorrer algumas aldeias da TIKL, logo percebi que não seria possível tratá-la como um todo homogêneo, pois eu pretendia observar as condições de acesso aos serviços biomédicos de atenção primária à saúde ofertados pela Equipe Multiprofissional de Saúde Indígena (EMSI), coordenada pelo Distrito Sanitário Manaus (DSEI-Manaus). Das 33 aldeias na TIKL, apenas duas contavam com um espaço físico para a atuação da EMSI, os dois polosbase: o Laranjal, situado às margens do rio Mari-Mari, e o Kwatá, às margens do Canumã. Em cada polo-base atuava uma EMSI composta por enfermeiros, técnicos de enfermagem, agentes indígenas de saúde (AISs), de saneamento (Aisans) e microscopistas (AIMs), piloto de lancha e auxiliar de serviços gerais. O médico da EMSI atendia nos dois polos-base. Assim, a EMSI de cada polo era responsável pela cobertura da atenção primária e imunização nas aldeias adstritas, conforme a localização ao longo do curso de cada rio, embora as equipes ficassem lotadas nos polos-base. Desse modo, as demais aldeias de cada rio sequer tinham um posto de saúde para a atuação da EMSI. Nessas aldeias, apenas os AISs, Aisans e AIMs eram os membros da EMSI que atuavam diariamente. Embora fossem previstas incursões da EMSI para as demais aldeias adstritas aos polos-base para ofertar atenção primária e imunização, questões de ordem logística exerciam impacto direto sobre a organização e a execução dessas entradas nas outras aldeias, como veremos ao longo do estudo, em particular no Capítulo 4.

O trabalho de campo mais intensivo foi realizado na aldeia Kwatá, na margem direita do rio Canumã. A população da aldeia Kwatá distribui-se em cinco porções: Caioé (105 habitantes), Emprezinha (59 pessoas), Tartaruguinha (63 pessoas), 
Cajoal (67 pessoas) e Kwatá (298), totalizando 592 habitantes. ${ }^{17}$ Realizei também trabalhos de campo mais breves na pequena aldeia Jacaré (com 30 pessoas), no rio Mari-Mari, a convite do conselheiro distrital de saúde daquele rio que morava na aldeia Jacaré, e na distante aldeia Niterói (94 pessoas), localizada no rio Canumã.

Durante boa parte da pesquisa de campo, moramos com Ceci, uma senhora de 92 anos que falava munduruku e português e ser tornou a principal interlocutora sobre os assuntos relativos à história, à língua e aos "costumes" dos Munduruku. ${ }^{18}$ Ela vivia com a família de Iara, sua filha de criação. Iara era casada, tinha três filhos e ficou grávida na última etapa da pesquisa de campo; assim, Iara também foi minha anfitriã.

A morfologia da aldeia Kwatá estava de tal forma organizada que um grupo de pessoas ligadas por relações de parentesco compartilhavam um mesmo "segmento residencial" (Melatti, 1978: 52). Por "segmento residencial" refiro-me a uma forma particular de ocupação territorial, na qual um conjunto de "famílias elementares" tinha suas casas dispostas próximas umas das outras, formando um espaço compartilhado pela "família extensa". Assim, era possível ver uma sobreposição entre "família extensa" e "segmento residencial" entre os Munduruku da TIKL. A "família elementar", segundo Melatti (1978), é formada por um grupo de pessoas que têm uma roça própria e formam um grupo separado dos demais na hora da alimentação. ${ }^{19} \mathrm{Na}$ TIKL, cada família elementar tinha uma casa distinta e uma roça própria. Com base no levantamento genealógico das famílias elementares, identifiquei a existência de segmentos residenciais formados por famílias extensas, isto é, por um conjunto de famílias elementares relacionadas entre si por laços de parentesco. Sendo assim, Iara, seu marido e três filhos, embora tivessem uma casa separada, formavam com Ceci uma família elementar, pois compartilhavam uma única roça e as refeições diárias. A casa de Ceci, por sua vez, era cercada pela casa de seus filhos e respectivas famílias.

A etnografia partiu, inicialmente, do segmento residencial em que morei na aldeia Kwatá e se estendeu, posteriormente, para outros segmentos residenciais em diferentes aldeias (Niterói e Cajoal) conforme a indicação dos próprios indígenas. A observação participante incluiu desde as atividades diárias até momentos festivos ou cerimoniais, entre os quais trabalhos realizados no âmbito da casa (cozinhar, buscar água, limpar o terreno etc.); práticas de autoatenção à saúde em casos de mal-estar breve ou de enfermidades sérias; práticas de resguardo do pós-parto; práticas relativas à menstruação; práticas relativas à gravidez; trabalho na roça; torras de farinha; rodas de conversa; consultas aos pajés e curadores; trabalhos do pajé; velório; festival do índio; reuniões de saúde; Assembleia da União dos Povos Indígenas Munduruku e Sateré-Mawé (Upims); atendimento básico no polo-base e consultas de pré-natal. Fiz também observação no Polo-Base Kwatá e na Casa de Apoio à Saúde do Índio (Casai). 
Ao longo deste trabalho, detalharei as relações sociais e as práticas cotidianas que permitem focalizar o desempenho dos laços sociais (Carsten, 2001; Viegas, 2003). Nessa perspectiva, a noção de parentesco deixa de ser tratada como um fenômeno dado, de ordem natural/biológica, preexistente e fundamentado nas noções de consanguinidade ou de aliança - questão já amplamente debatida e criticada no interior dos estudos do parentesco (Carsten, 2004; Schneider, 1984) - para ponderar outros elementos constituidores das relações de parentesco moldados nas performances diárias e no engajamento nas atividades cotidianas de trabalho, alimentação e nas práticas de autoatenção à gestação, parto e pós-parto.

Na pesquisa de campo, acompanhei o cotidiano e em especial os casos de gestação, parto e pós-parto. Pude também observar e conversar com famílias elementares de segmentos residenciais de outras aldeias onde realizei uma pesquisa de campo de curta permanência, entre as quais havia mulheres grávidas ou em resguardo de pós-parto.

Em geral, nesses contextos o objetivo foi conversar sobre o tema da pesquisa e ouvir as experiências passadas daqueles casais dispostos a compartilhar. Foram muitas as pessoas quem tive conversas informais, das quais algumas foram gravadas em áudio e outras apenas registradas no caderno de campo. Desse modo, o levantamento etnográfico, em termos gerais, consistiu em observar práticas sociais e coletar interpretações nativas sobre práticas relativas a gestação, parto e pós-parto.

\section{Gestação, parto e pós-parto como processos de autoatenção}

Após oito meses de trabalho de campo entre os Munduruku da Terra Indígena Kwatá-Laranjal (TIKL), Amazonas, ficou evidente a complexidade sociológica e cosmográfica que emerge das ações sociais inauguradas em torno do nascimento de um novo membro e de sua inserção na família. Optei, então, por reconstruir o processo de nascimento entre os Munduruku a partir das práticas de "autoatenção" (Menéndez, 2009: 48) relativas à gestação, ao parto e ao pós-parto observadas durante o trabalho de campo. Adotei esse recorte da observação focalizado nas práticas de autoatenção foi uma estratégia metodológica para não incorrer nas aparentes contradições e incompatibilidades reproduzidas, em geral, nos discursos dos especialistas das diversas formas de atenção à saúde e às enfermidades (Menéndez, 2003). Especialmente porque esse contexto de pluralidade de formas de atenção à saúde era comum também ao Munduruku da TIKL. Porém, como veremos ao longo deste livro, alguns especialistas Munduruku também indicaram o uso dos serviços biomédicos entre suas práticas. 
Uma mirada social sobre a gestação, parto e pós-parto, em especial sobre as práticas de autoatenção manejadas pelos Munduruku ao longo desse processo de nascimento, permitiu salientar as relações transacionais operadas entre as diversas formas de atenção à saúde existentes no contexto da TIKL. Permitiu também evidenciar a participação de uma diversidade de especialistas representantes de diferentes formas de atenção à saúde bem como da participação de pessoas que, embora não fossem especialistas, tinham legitimidade social para atuar, conforme veremos no Capítulo 5. Segundo Menéndez, a noção de autoatenção compreende um sentido restrito e outro amplo. O sentido restrito refere-se a

representações e práticas que a população utiliza tanto individual quanto socialmente para diagnosticar, explicar, atender, controlar, aliviar, suportar, curar, solucionar ou prevenir os processos que afetam sua saúde em termos reais ou imaginários, sem a intervenção central, direta e intencional de curadores profissionais, embora eles possam ser os referenciais dessa atividade. (Menéndez, 2009: 48)

Embora a gestação, o parto e o pós-parto não fossem tratados pelos Munduruku como eventos de doenças, uma série de práticas inauguradas e manejadas ao longo desses processos estava relacionada, de modo mais ou menos específico, aos processos de saúde/doença/atenção, pois articulava saberes voltados, por exemplo, para a manutenção do bem-estar da mãe, do pai e do feto ou recém-nascido. Ainda segundo Menéndez, o sentido amplo de autoatenção abrangeria

todas as formas de autoatenção necessárias para assegurar a reprodução biossocial do grupo a nível dos microgrupos, e especialmente do grupo doméstico - formas que são utilizadas a partir dos objetivos e normas estabelecidos pela própria cultura do grupo. A partir desta perspectiva, podemos incluir não só a atenção e prevenção dos padecimentos, mas também as atividades de prevenção dos padecimentos, a higiene do lar, do entorno e do corpo, a obtenção e uso da água, etc. (Menéndez, 2009: 48)

É nesse sentido que as práticas relativas à gestação, ao parto e ao pós-parto manejadas pelos Munduruku observadas em seu conjunto podem ser incluídas entre as práticas de autoatenção ao nascimento de um novo ser. A definição dos sentidos amplos e restritos da noção de autoatenção é apresentada por Menéndez (2009: 49) como um recorte metodológico em que o limite entre uma noção e outra é difícil de estabelecer, embora "opere como um mecanismo de ordenamento da realidade". Entretanto, dada a complexidade do processo de gestação, parto e pós-parto, sugiro que tais sentidos estão muito mais entrelaçados do que qualquer distinção a priori. Especialmente se considerarmos o longo processo histórico de contato desse povo com diferentes frentes, atores e agências da sociedade nacional, cujos efeitos contribuíram e continuam contribuindo para os processos de reprodução e transformação 
das formas de autoatenção. Um processo longo e lento, porém inerente ao processo histórico de toda e qualquer sociedade humana, visto que a cultura é dinâmica. Cumpre esclarecer que neste trabalho utilizo a noção de cultura como processo simbólico vivido por sujeitos concretos em realidades empíricas que procedem cotidianamente tomando decisões, refletindo, avaliando, corrigindo, adaptando, questionando e transformando sua realidade próxima. Em outras palavras, é preciso focalizar a práxis individual e coletiva como processo dinâmico por meio do qual se atualiza um "modelo de" e um "modelo para" agir no mundo (Geertz, 1989; Langdon, 1995; Ortner, 2006). As práticas de autoatenção são agenciadas pelos sujeitos e estruturadas historicamente, constituindo-se em saberes transmitidos ao longo das gerações, como também estruturantes das relações sociais cotidianas, em especial daquelas inerentes aos grupos primários, como as relações de troca que se observam no grupo familiar que incluem o compartilhamento de alimentos, de fluidos corporais e redes de apoio mútuo.

Nessa perspectiva, é importante resgatar um aspecto da autoatenção salientado por Menéndez (2009), segundo quem os sujeitos sociais, com base em experiências pessoais e coletivas, utilizam diferentes saberes e formas de atenção e, ao mesmo tempo, sintetizam, articulam, misturam ou justapõem esses diferentes saberes e formas. Assim, é pertinente analisar o crescente contato do povo munduruku com as formas estrangeiras de atenção aos padecimentos, que remontam aos primeiros contatos com os missionários de diversas ordens religiosas e nacionalidades que adentraram a região do Tapajós-Madeira no período colonial a partir do século XVII.20

\section{O povo munduruku: breve contextualização histórica}

Atualmente há índios Munduruku em terras indígenas situadas nos estados do Pará, do Mato Grosso e do Amazonas. Esta etnografia refere-se ao grupo que habita o Amazonas, na TIKL, especialmente, as aldeias às margens do rio Canumã. Esse grupo representa a segunda maior população de índios Munduruku no Brasil.

O povo munduruku foi historicamente retratado como destemido e brava nação de guerreiros que expandiu seu território das áreas de transição entre as savanas e a floresta tropical localizadas no interior das terras do Alto Tapajós em direção ao curso do rio do Baixo Tapajós, ao vale do Madeira e do Baixo Amazonas, reocupando uma vasta região, durante os séculos XVIII e XIX. Os relatos históricos registram que no auge do movimento expansionista as incursões guerreiras dos Munduruku alcançaram o Xingu, o Tocantins e as fronteiras do Maranhão (Ribeiro, 2002: 55; Santos, 2002: 134). Aires de Casal (1817: 323), ao descrever a Província do Pará, falou na comarca "Mundrucânea", limitada ao norte pelo rio Amazonas, 
ao sul pelo Juruena, a leste pelo Tapajós e a oeste pelo Madeira, para registrar a enorme extensão territorial ocupada por esse povo. Os Munduruku eram o povo, numérica e belicosamente, superior na região durante os séculos XVIII e XIX e disputavam território com outros povos, como os Juma, Mauê, Pama, Parintintin, Mura, Andirá e Arara. ${ }^{21}$ Não apenas esses grupos indígenas sentiram a feroz pressão dos Munduruku à época, o que levou muitos a procurar abrigo nas missões religiosas e outros a migrarem para lugares cada vez mais distantes, como também os portugueses se viram pressionados pelas incursões de guerra do grupo (Amoroso, 1992; Menéndez, 1992; Santos, 2002). Consta que em 1795 os Munduruku fizeram uma aliança com a administração colonial portuguesa na localidade hoje conhecida como cidade de Borba, à beira do rio Madeira, no estado do Amazonas (Arnaud, 1974; Ioris, 2005; Menéndez, 1992; Santos, 2002). Isso gerou certo alívio para os administradores e colonos portugueses, sempre temerosos de um levante, e também contribuiu para manter "certa integridade e autonomia tribal e o poder político dos seus chefes [Munduruku], alcançado pelo relevante papel que exerciam na guerra" (Ribeiro, 2002: 56).

Esse processo migratório e de expansão do território original munduruku contribuiu para acentuar um reordenamento nas relações interétnicas na região do Tapajós-Madeira durante os séculos XVIII e XIX (Menéndez, 1981; Ramos, 2000; Ioris, 2005; Scopel, 2013). A expansão territorial munduruku, iniciada por volta de 1770, deveu-se a pelo menos três motivos, de diferentes ordens: primeiro, o enfraquecimento das nações Tapajós e Tupinambá em razão da hostilidade e das sucessivas epidemias resultantes do contato com os brancos, o que teria deixado um vácuo naquela área (Menéndez, 1992);22 segundo, razões mercenárias, ao menos após o tratado de paz com os portugueses (Ribeiro, 2002); terceiro, e não menos importante, uma motivação relacionada ao ethos guerreiro dos Munduruku, a busca por cabeças de inimigos e por mulheres e crianças (Murphy, 1958, 1960). As primeiras eram exibidas como troféus e ocupavam papel central nas atividades de caça e nas cerimônias rituais de propiciação das mães da mata e dos animais de caça (Tocantins, 1877; Murphy, 1958; Menget, 1993, 1996). As mulheres e crianças cativas seriam integradas plenamente na sociedade munduruku como esposas e filhos (Murphy, 1958; Tocantins, 1877).

As facilidades médicas encontradas nas diversas missões religiosas fundadas ao longo do rio Cururu, no Alto Tapajós, principalmente no século XX, foram também citadas entre os motivos para os descimentos de grupos Munduruku (Arnaud, 1974).23 É importante lembrar que, naquele momento, os serviços médicos eram um bem escasso na região, restrito aos missionários, colonos e comerciantes. Somente no início do século XX o governo brasileiro criou uma instituição cujas atribuições incluíam, entre outras atividades, a prestação de serviços médicos aos grupos indígenas contatados. Foi o caso do Serviço de Proteção ao Índio e Locali- 
zação do Trabalhador Nacional, mais conhecido como SPI, criado em 1910. O SPI foi o órgão do Ministério da Justiça responsável pelas primeiras demarcações de terras indígenas no Brasil e pela promoção de atendimento médico, distribuição de medicamentos e vacinações (Arnaud, 1989). ${ }^{24}$

As missões religiosas e o ingresso nos empreendimentos da borracha teriam contribuído para a dispersão dos Munduruku da região das savanas para as margens dos rios Tapajós, Madeira e de seus afluentes (Arnaud, 1974; Menéndez, 1992; Murphy, 1958, 1960). Em certa medida, a empresa da borracha acabou por colocar os Munduruku num circuito de economia local e global, no qual se inseriram como parte de uma extensa rede de produção e circulação de mercadorias (Wolf, 1997). Antes da borracha, os Munduruku, notadamente nas aldeias ao longo do rio Canumã, já acalentavam o comércio local ao produzirem grandes quantidades de farinha, que eram vendidas aos portugueses (Spix G Martius, 1976; Wolf, 1997). ${ }^{25}$

As sucessivas levas de migração teriam acentuado as transformações no modo de vida social e econômico dos povos munduruku a partir do início do século XIX, influenciados pelo contato com a população não indígena vizinha, com o trabalho na extração da borracha e com as missões religiosas. Além do abandono das práticas de guerra e da caça de cabeças de tribos inimigas, as quais repercutiram no abandono de uma série de cerimônias e ritos, também foram sugeridas mudanças na organização social de alguns agrupamentos munduruku (Murphy, 1958; Murphy G Murphy, 2004; Tocantins, 1877). As diferenças mais visíveis entre os aldeamentos munduruku localizados nas áreas de savana e aqueles situados às margens do Tapajós e seus afluentes estavam na distribuição e concentração demográfica e no padrão arquitetônico das aldeias, como o abandono da casa dos homens, e na organização social do trabalho, com a emergência da "família nuclear" como unidade de produção e consumo (Murphy G Murphy, 2004: 213). Houve, contudo, mudanças que foram identificadas em ambos os grupos, como, por exemplo, no padrão de residência (de virilocal para uxorilocal), ${ }^{26}$ nos modos de subsistência (a caça deixara de ser a fonte principal de proteínas e fora substituída pela pesca, especialmente nos aldeamentos às margens do rio), nos mitos (a incorporação de eventos históricos e de temas da religião católica), nas cerimônias religiosas (o fim dos ciclos rituais que eram parte do "complexo da caça de cabeças"), além da depopulação geral e, em específico, do número de xamãs (Murphy, 1958). No entanto, quanto à mudança no padrão de residência após o casamento, de virilocal para uxorilocal, Ramos (1978) fez uma revisão crítica dos dados de Murphy e propôs outra interpretação, sugerindo que não haveria evidências etnográficas para se afirmar um padrão de residência originalmente virilocal. ${ }^{27}$ Em Women of the Forest (Murphy G Murphy, 2004), vemos que as mudanças no padrão de residência após o casamento são matéria de grande complexidade, posto que os autores encontraram diferenças e contradições entre os aspectos normativos e a prática cotidiana, esta última muito mais flexível e fluida 
do que a primeira. Segundo o casal Murphy, com a migração dos aldeamentos nas savanas para as margens do Tapajós, a residência após o casamento havia deixado de ser principalmente uxorilocal, passando a abranger também conformações neonatal e virilocal.

E quanto ao fim das expedições de guerra, não restaram dúvidas. O abandono das expedições de guerra repercutiu também na interrupção de uma série de cerimônias realizadas após as expedições (Murphy, 1958). As cerimônias da guerra eram compostas de ciclos rituais com diferentes nominações e finalidades, realizadas nas estações de chuva. Após três anos de ritual, o guerreiro que havia retornado da guerra com a cabeça de um inimigo assumia o status de "mãe do pecari" (Murphy, 1958: 54). De acordo com Murphy, esses ciclos rituais consistiriam em um rito de passagem em que o dono da cabeça-troféu se tornaria a "mãe do pecari", adquirindo, ele e sua cabeça-troféu, um status religioso e social importante nas expedições de caça e na relação com o espírito da mãe da caça. Eles tinham o poder de incrementar a própria economia da caça, uma vez que a mãe do pecari e sua cabeça-troféu atrairiam a mãe da caça, o que contribuiria para o êxito das caçadas coletivas. Ainda segundo Murphy (1958), a caça de cabeças se inseria no rito masculino de iniciação chamado Duparip. As mulheres dos guerreiros que se tornavam "mãe do pecari" também assumiam um status e papel diferenciado nas preparações para as expedições de caça. Há mesmo relatos em que se descreve a participação ativa das mulheres Munduruku nos combates realizados durante as expedições de caça, em que elas agarrariam as flechas dos inimigos para munir seus esposos (Spix G Martius, 1976). Segundo esse autor, as "mães do arco" formariam uma "sociedade dos homens" em que todo homem adulto com status de guerreiro participaria. No terceiro ano do ciclo ritual, os homens agregados ao grupo de "mães do arco" cantariam durante a noite e sua entrada na aldeia não poderia ser vista pelas mulheres. As mulheres deveriam permanecer em casa, pois avistar a entrada daqueles homens na aldeia seria um presságio de morte: "seria morto durante a próxima guerra" (Murphy, 1958: 57).

Além disso, nem todo guerreiro se tornaria "mãe do pecari". Apenas o homem que completasse o ciclo cerimonial carregaria esse "título e distinção" por toda sua vida (Murphy, 1958: 58). Segundo Menget (1996), esse ritual envolveria uma questão de transformação (da cabeça do inimigo em "cabeça-troféu" e do guerreiro em "mãe do pecari") e também refletiria uma relação social de troca (compensação) entre homens e animais. Todavia, mais interessante é a sugestão desse autor de que o ciclo ritual relativo à cerimônia da guerra, especialmente em sua fase final, colocaria em jogo expressões das "principais oposições na sociedade munduruku (entre as metades, entre os grupos etários, entre os sexos, entre inimigos e concidadãos)" (Menget, 1996: 137, tradução minha).

A conclusão de Murphy sobre a função da guerra na estrutura social munduruku parte de uma análise das cerimônias e mitos e aponta para duas dimensões 
interconectadas, uma relativa ao indivíduo e outra ao grupo. O ciclo ritual expressaria uma função heurística dedicada ao estímulo pessoal, como um "incentivo pessoal" para despertar nos indivíduos o desejo de alcançar o status de guerreiros e "mães de pecari", ao mesmo tempo que apareceria como "meio para doutrinar os jovens no militarismo de que eles um dia viriam a participar" (Murphy, 1958: 58, tradução minha). ${ }^{28}$ A guerra, a "cabeça-troféu", o status do guerreiro e suas cerimônias eram, para Murphy, uma das bases que integravam a sociedade munduruku, seus diferentes clãs e grupos corporalizados, e representavam o "traço tradicional da cultura Mundurucú". De acordo com Menget (1996), a guerra e a "caça de cabeças" poderiam ser vistas como formas de reprodução física, busca de cativos (mulheres e crianças), e simbólica das estruturas de poder e prestígio na sociedade munduruku, cuja organização social seria internamente formada por clãs e fratrias (grupos de clãs), de descendência patrilinear, que compunham as duas metades exogâmicas (isto é, o casamento deveria ocorrer entre pessoas pertencentes a diferentes clãs e fratrias). Segundo Murphy (1958), o fim da guerra repercutiu diretamente sobre a coesão social dos Munduruku, pois era através da guerra e dos ritos subsequentes que valores centrais eram repassados e afirmados. Esses valores fundamentavam princípios comuns, o incentivo e o desejo de ser um guerreiro, e seus rituais eram meios institucionalizados de resolver hostilidades internas no grupo.

Notável, aqui, é o fato de o guerreiro ser considerado mãe e dever seguir, digamos, uma prática de resguardo, um conjunto de prescrições e proibições, que seriam demarcadas por performances rituais e papéis sociais importantes para reafirmar e reposicionar o status de sujeito. Mais interessante ainda seria observar a cooperação entre as atividades dos homens e das mulheres para alcançarem o sucesso nesse processo. Menget (1996) lembra que o ciclo ritual para a obtenção de uma "cabeça-troféu" envolvia a tomada de decisão e o compromisso, pois a mudança de status envolveria riscos e implicaria uma série de prescrições e proibições alimentares e sexuais que incidiriam sobre o oficiante e sua esposa. Assim, podemos enfatizar que os esforços conjuntos do casal - marido e mulher - na prática diária ao longo do ritual implicariam cooperação, ainda que esse ritual tenha sido descrito por Murphy (1958) como expressão fortemente marcadora do prestígio masculino vinculada às atividades de caça e guerra. Cumpre esclarecer que os relatos sobre esse ritual, bem como aqueles que enfatizavam o prestígio dos homens e de suas atividades, deveriam ser compreendidos em uma perspectiva masculina sobre a ideologia do grupo, conforme o casal Murphy (2004) destacou em outro momento. Ao concluírem que a perspectiva das mulheres seria diferente, Murphy e Murphy (2004) colocaram em relevo a vida cotidiana dos Munduruku, que pouco refletia as assimetrias expressas nos mitos e códigos normativos do grupo.

Os Munduruku deixaram de caçar cabeças, e isso repercutiu na continuidade de uma série de mitos e cerimônias, que também cessaram. Todavia, a coo- 
peração entre homens e mulheres continuou central para a reprodução biossocial do grupo, como veremos no capítulo a seguir.

De certa forma, os registros históricos sobre a área Tapajós-Madeira aqui tratados evidenciaram, inicialmente, uma amplificação das dinâmicas próprias dos grupos indígenas intensificadas a partir dos efeitos do contato com o branco. Entre os efeitos desse contato, devemos destacar a violência e as epidemias (Menéndez, 1992: 290; Scopel, 2013; Tocantins, 1877: 140). Em certa medida, assim como as epidemias passaram a ter grande importância entre os indígenas a partir do contato colonial, os recursos biomédicos também vieram juntos, ainda que paulatinamente e sempre aquém das primeiras. E, ao que parece, foram apropriados como um bem valorizado pelos indígenas desde o início do contato até os dias de hoje.29

Os relatos sobre a área Tapajós-Madeira sugerem inúmeros, sucessivos e crescentes contatos e relações comerciais entre indígenas e não indígenas. Durante minha pesquisa de campo, observei uma série de contextos nos quais os Munduruku se inseriam em relações interétnicas, sobretudo nas frequentes viagens que faziam para as cidades próximas e até para a capital do estado, Manaus.

Além da cidade de Borba, os Munduruku frequentavam a cidade de Nova Olinda do Norte, pela proximidade com a TIKL. Lá iam fazer compras, visitar parentes, receber benefícios como Bolsa Família ou aposentadorias e realizar exames de saúde, consultas médicas e, em alguns casos, partos, entre outros motivos relacionados à forma de atenção biomédica. Em Nova Olinda do Norte situava-se também o posto da Funai, responsável por emitir a documentação necessária para requisitar auxílio-maternidade ao Ministério de Previdência Social.

Conforme relatou Scopel (2013), os Munduruku procuravam a cidade de Nova Olinda do Norte até mesmo para realizar consultas com curadores indígenas de outras etnias e também não indígenas, para tratar "assombração de bicho do fundo", desmentiduras, curar feitiços, entre outras perturbações não suscetíveis de tratamento biomédico. Compravam também materiais e insumos em casas de venda de produtos de umbanda para realizar rituais com os "curadores pajés" da terra indígena.

Às casas de comércio e supermercados referiam-se como "meu patrão", pois ali adquiriam produtos de gêneros variados, desde alimentos, roupas, material escolar, material de limpeza, produtos de higiene, incluindo medicamentos e remédios até artefatos para uso na roça ou pesca, entre outras coisas mais. Muitas vezes, podiam compatibilizar essas viagens de compras no "patrão" com a necessidade de realizar exames ou visitar parentes no hospital. Nesses casos, os Munduruku preferiam viajar nas próprias canoas, abrindo mão da lancha do polo-base.

Em Nova Olinda do Norte também estava localizada a Casa de Apoio à Saúde do Índio (Casai), parte do Subsistema de Saúde Indígena. Trata-se de uma 
edificação com salas de trabalho administrativo e acomodações para pacientes que incluía quartos, banheiros e cozinha. Nela trabalhavam técnicos de enfermagem, agentes indígenas de saúde, motorista, cozinheira e vigia. Não se realizavam consultas ou exames na Casai, uma vez que a estrutura servia de apoio aos indígenas que precisavam permanecer na cidade ou estavam em atendimento no hospital. Dentre esses procedimentos, cabe ressaltar que a Casai foi utilizada pelas mulheres que realizaram partos no hospital. Nesse caso, elas permaneceram ali por alguns dias após o parto, antes de retornar às suas aldeias de origem. Tratarei da importância da Casai no cumprimento do resguardo do pós-parto com mais detalhes no Capítulo 6.

Até aqui, procurei mostrar que a região do Tapajós-Madeira foi palco de uma série de eventos que contribuiu para reordenamentos econômicos, territoriais e populacionais da região em diferentes momentos históricos registrados desde o período colonial, no início do século XVII. Expedições exploratórias e para a captura de índios para mão de obra escrava, missões religiosas, elevação das missões em vilas, revoltas populares e exploração da borracha foram alguns dos eventos que mobilizaram sucessivos fluxos migratórios. Nessa linha do tempo, o efeito que transpassa os diversos momentos de contato e as diferentes políticas de relação com as populações indígenas locais é o realinhamento das relações interétnicas e o contato crescente com a biomedicina. Nesse sentido, a atual inserção dos Munduruku no cenário regional se caracterizaria por um constante fluxo que não se restringiu aos limites da Terra Indígena Kwatá-Laranjal. É nesse contexto mais amplo, da inserção histórica e geográfica dos Munduruku da TIKL, que podemos compreender o processo de medicalização, não como um processo abstrato e desterritorializado, mas articulado com estruturas locais, ainda que em consonância com processos paralelos de expansão colonialista (Greene, 1998) e desenvolvimentista (Frankenberg, 1980).

Notas

13 A cidade de Borba resultou da fundação de uma missão por um padre jesuíta que, por volta de 1712, subiu o rio Madeira catequizando índios e construindo igrejas. A atuação desse padre resultou na fundação, em 1724, da aldeia de Santo Antônio de Araretama (das Cachoeiras) entre o rio Jamari e a primeira cachoeira do Madeira, onde trabalharam diversos missionários. Segundo Miguel de Menéndez (1992) e Amoroso (1992), essa missão mudou várias vezes de local ao longo do rio Madeira, sendo, por fim, transferida para a localidade de Trocano, devido aos constantes ataques de índios Mura. A aldeia de Trocano congregou indígenas de diversas etnias, alguns europeus, mestiços e negros (Casal, 1817: 326). Essa missão foi elevada à categoria de vila de Borba em 1756.

14 Dados obtidos na Fundação Nacional de Saúde (Funasa), no setor administrativo da Casa de Apoio à Saúde Indígena (Casai) localizada na cidade de Nova Olinda do Norte, em 2009. Todos os dados demográficos que apresento neste capítulo são originários dessa fonte. 
15 Entretanto, qualquer índio Munduruku sabia nomear na língua original animais de caça e alguns seres que habitariam o cosmo. Havia também um evidente esforço para não perder o contato com a língua, o que se evidenciava com as aulas de munduruku ministradas nas escolas por professores indígenas no interior da TIKL. Assim, as crianças sabiam, além dos nomes de animais de caça, algumas frases relacionadas à vida cotidiana, especialmente as atividades de trabalho. Sabiam, por exemplo, em munduruku, falar que estavam indo tomar banho, pescar, caçar, conversar com um amigo, fazer farinha.

16 Iniciei o trabalho de campo com os Munduruku da TIKL motivada por outras duas pesquisas. Em novembro de 2008, iniciei a pesquisa "Avaliação do modelo de atenção diferenciada aos povos indígenas: os casos Kaingáng (Santa Catarina) e Munduruku (Amazonas)", coordenada pela professora Esther Jean Langdon, da Universidade Federal de Santa Catarina. Em fevereiro de 2009 iniciei a pesquisa "Atenção primária e Equipe Multiprofissional de Saúde Indígena: uma abordagem da antropologia da saúde sobre o papel social do agente indígena de saúde no subsistema de atenção à saúde ao índio no estado do Amazonas (Distrito Sanitário Especial Indígena de Manaus)", realizada entre as populações Mura e Munduruku. Essa pesquisa foi coordenada por mim, pesquisadora da Fundação Oswaldo Cruz/Instituto Leônidas e Maria Deane, e financiada pela Fundação de Amparo à Pesquisa no Estado do Amazonas. Em razão dessas duas pesquisas, estou em contato com os Munduruku da TIKL desde meados de 2007, quando participei pela primeira vez da reunião do Conselho Local de Saúde na aldeia As Cobras.

17 Essa subdivisão em porções da aldeia Kwatá correspondia a uma estratégia dos serviços de saúde biomédicos para organizar as atividades de trabalho e o registro de dados. Os residentes indígenas, entretanto, afirmam tratar-se de uma única aldeia, ainda que tivessem nomes distintos e não fosse possível se deslocar a pé por toda a sua extensão.

18 Nesta publicação utilizo pseudônimos, salvo quando o nome verdadeiro é relevante para o registro etnográfico.

19 Embora Melatti se referisse à organização familiar dos Krahó, um grupo timbira da família linguística jê, sugiro a pertinência desses termos para descrever a organização morfológica atual das aldeias na TIKL.

20 Arnaud (1989), Ioris (2005), Collevatti (2009), Miguel de Menéndez (2002) e Amoroso (1992) citam as diversas missões religiosas instaladas na área Tapajós-Madeira ao longo dos séculos XVII, XVIII, XIX e XX. Em geral, um ponto comum nessas missões foi agregar entre seus catecúmenos uma diversidade de etnias indígenas. Às missões que persistiram até a era pombalina, em meados do século XVIII, e que foram elevadas à categoria de vilas, juntaram-se também os colonos. De modo geral, as relações entre a Coroa portuguesa e as missões de diversas ordens religiosas sofreram oscilações ao longo da história do período colonial e no Brasil imperial. Fora dada carta aberta ao trabalho dos missionários jesuítas para catequizar e evangelizar na área Tapajós-Madeira, no início do século XVII. Porém, em meados do século XVIII, o marquês de Pombal proibiu a atuação missionária e promoveu uma transformação na relação entre o Império e os indígenas descidos. Na era pombalina, as missões foram elevadas à categoria de vilas, passando a ser administradas pelo poder secular, e a língua portuguesa foi considerada oficial, substituindo o uso da língua geral, uma derivação do tupi ensinada pelos missionários. Os indígenas foram também considerados livres para trabalhar e comercializar de modo independente, isto 
é, sem a intermediação e proteção dos missionários. A política pombalina incluía, ainda, o incentivo do casamento entre colonos e mulheres indígenas e tinha um programa para o desenvolvimento da agricultura na região (Amoroso, 1992).

21 Muitos autores registraram a diversidade de povos indígenas na área Tapajós-Madeira e discutiram sobre os diversos movimentos migratórios, as sucessivas reordenações das relações interétnicas e o contato com a sociedade nacional (Amoroso, 1992; Casal, 1817; Collevatti, 2009; Ioris, 2005, 2006, 2011; Melatti, 2010; Menéndez, 1992; Santos, A. F. M., 2009; Santos, F., 1995; Scopel, 2013; Tocantins, 1877; Wawzyniak, 2008).

22 O registro da presença de uma diversidade linguística, étnica e cultural na área Tapajós-Madeira, ao menos desde o processo de ocupação portuguesa da região, permite compreender que a área Tapajós-Madeira foi palco de diversos processos de ocupação de territórios e de transformações nas relações interétnicas. Segundo Miguel de Menéndez (1992), os índios Tapajós e Tupinambá foram numérica e belicamente superiores aos demais grupos indígenas que habitavam a área Tapajós-Madeira, em meados do século XVII. Trinta anos após a instalação da Missão Tapajós, em 1661, na boca do rio Tapajós, onde hoje é Santarém, a qual congregou indígenas de diversas etnias e se tornou um polo econômico e religioso central na região do Amazonas, registrou-se uma depopulação no contingente indígena que habitava a área da boca do Tapajós e já não se falava mais na etnia Tupinambá (Menéndez, 1992).

23 Arnaud (1974) se referia às missões dos frades franciscanos alemães fundadas na bacia do Tapajós por volta de 1911. Murphy e Murphy (2004) também citaram a busca de remédios pelos Munduruku, solicitados amiúde ao casal durante a pesquisa de campo feita entre 1952 e 1953.

24 Collevatti (2009: 241), ao analisar as cartas dos frades franciscanos sobre as missões estabelecidas no rio Cururu, registra que os Munduruku recorreram às missões para "negociar, participar das festas, utilizar a enfermaria ou enviar seus filhos à escola".

25 A área do Tapajós-Madeira contribuiu para estimular o mercado local, nacional e internacional envolvido no comércio da borracha com os inúmeros seringais no Tapajós e no Baixo Amazonas (Arnaud, 1974; Collevatti, 2009; Santos, 2009). E também para um novo reordenamento nas relações interétnicas, pois, conforme frisa Collevatti (2009: 229), com o recrudescimento do comércio da borracha na área Tapajós-Madeira houve um "aumento expressivo do contingente populacional da região, formado por trabalhadores migrantes do Maranhão, Ceará e Mato Grosso, devido ao estabelecimento de residências e postos de comércio permanentes no Alto Tapajós e nos rios Juruena e São Manoel". Arnaud (1989) também cita a migração de paraenses, cuiabanos, negros, além de estrangeiros venezuelanos, peruanos, equatorianos e alguns europeus que vieram trabalhar ou nos seringais ou no comércio da borracha como "patrões", donos de regatões ou comerciantes urbanos. Esse aumento do contingente populacional na área Tapajós-Madeira intensificou a densidade demográfica das vilas e passou a fazer parte da vida dos Munduruku na medida em que estes se envolviam na extração da borracha nos seringais ou no comércio da borracha.

26 Virilocal, uxorilocal e neolocal são termos utilizados para indicar o padrão de residência após o matrimônio em que os cônjuges passam a residir, respectivamente, com os parentes da linhagem do marido, da mulher ou em um novo local. 
27 Em reflexão teórica baseada nos dados etnográficos de Murphy sobre as memórias munduruku acerca da residência após o casamento, Ramos (1978) concluiu que os Munduruku seguiam um padrão uxorilocal de residência.

28 Tocantins (1877: 84) registrou que um dos motivos para as expedições de guerra feitas pelos Munduruku era a captura de mulheres e crianças, além da caça de cabeças de seus inimigos preferenciais, os Parintintin.

29 Alguns autores têm destacado o papel dos recursos biomédicos, principalmente dos medicamentos e cargos profissionais, como bens incorporados pelos indígenas em suas vidas cotidianas que assumem um papel importante nas relações políticas das aldeias (Garnelo, 2003; Langdon et al., 2006). 


\section{O Cotidiano dos Munduruku: a vida na aldeia Kwatá}

Apresentarei aqui com mais detalhes as atividades que ocupam a vida diária dos índios Munduruku. As descrições se concentram em observações realizadas na aldeia Kwatá. Quando for o caso, especificarei as origens das observações feitas em outras aldeias. As descrições apresentadas neste capítulo são certamente reconstruções a posteriori estruturadas com o objetivo específico de salientar as práticas munduruku no âmbito da família, como grupo social, por meio das performances cotidianas das relações sociais e afetivas envolvidas na economia de subsistência. Trata-se, assim, de fornecer ao leitor um modelo, no qual procurarei destacar algumas atividades de homens, mulheres, crianças, jovens e seniores Munduruku. ${ }^{30}$

O foco principal deste capítulo é a atuação de uma família extensa nas atividades de produção, circulação e consumo dos alimentos, incluindo também outras atividades da vida diária na aldeia com o objetivo de sublinhar que a família é um grupo que se estrutura em torno das práticas de autoatenção à saúde, das atividades de trabalho e apoio mútuo. Escrevo sobre isso para explorar a dimensão das relações sociais envolvidas nesse processo, situando-o em determinado contexto social, o da vida diária, para que o leitor compreenda posteriormente:

1. a centralidade das relações sociais instauradas em torno da alimentação na gestação, parto e pós-parto;

2. a importância da dieta alimentar na produção das características físicas e morais das crianças e na realização de partos e pós-partos em conformidade com as expectativas sociais munduruku; e

3. as inversões instauradas pelas práticas de autoatenção à saúde relativas ao período do resguardo do pós-parto, em específico aquelas relacionadas à divisão sexual do trabalho.

Utilizo o termo economia de subsistência inspirada em Gow (1989), como categoria de análise que articula aspectos do meio ambiente físico e fatores sociais e culturais envolvidos na produção, circulação e consumo de determinados alimentos. Ao considerar a dimensão das relações sociais envolvidas nesse processo situando-o em determinado contexto cultural, Gow (1989: 581) amplia uma acep- 
ção de economia de subsistência restrita à satisfação das necessidades humanas básicas. Isso reforça uma perspectiva antropológica preocupada em salientar a dimensão social e cultural da família e do gênero, entre as populações indígenas, já em torno da década de 1980. Desde aquela época, esses conceitos deixaram de ser pensados como fenômenos de ordem natural e biológica para serem observados como construções socioculturais e historicamente situadas. Ponderar também sobre o contexto situacional das relações socais envolvidas nas relações de produção, circulação e consumo dos alimentos, isto é, atentar para a contingência marcada pelo processo de nascimento (gestação, parto e pós-parto), por exemplo, permite entender as práticas de construção social das diferenças entre pessoas Munduruku. Assim, torna possível ponderar sobre as formas particulares como as atividades humanas, cujas consequências e significados (re)criam e mantêm processos sociais e simbólicos, repercutem na demarcação de interesses e estratégias relativas a determinada situação.

\section{A vida na aldeia}

A vida na aldeia começava cedo. Era possível escutar o som dos passos das pessoas caminhando ou de uma rabeta - canoa de madeira movida por pequeno motor de popa - navegando antes mesmo do dia clarear. Iara, filha de nossa anfitriã Ceci, costumava levantar nas primeiras horas do dia. Ela trabalhava na cozinha da casa, organizava as louças e panelas usadas na noite anterior, limpava a mesa, varria o chão, passava o café, adoçava-o e despejava-o na garrafa térmica que o conservava quente para o desjejum dos demais membros da família. Os três filhos de Iara acordavam em seguida. Por volta das 6 horas todos já haviam tomado banho no rio e estavam tomando café acompanhado de bolacha, pão ou biju. Iara também deixava pronto chá, em geral com folhas de abacate, para sua mãe Ceci beber no desjejum. Após o café, durante o período letivo, Nina e Raoni seguiam para a escola junto com as demais crianças. Raí estudava no período da tarde. Notava-se que todas as crianças que passavam em frente a nossa casa estavam bem arrumadas para frequentar a aula. Fora das salas de aula, em geral, as crianças andavam descalças e, devido ao calor, os meninos sem camisa. Os alunos da $5^{\mathrm{a}}$ à $8^{\mathrm{a}}$ série usavam camisetas azuis do uniforme da escola; calças e saias jeans eram muito comuns. Os mesmos cuidados com a aparência e as vestimentas também apareciam nas missas ou cultos de domingo. De certo modo, os Munduruku faziam uma seleção entre roupas para uso diário e trabalho e roupas para a escola, a missa, o culto ou para a cidade. Ceci, embora já estivesse acordada por volta das 7 horas, esperava a manhã esquentar antes de sair da cama, pois estava se recuperando de um "derrame" que a deixara com "frio nas pernas". 31 A depender do dia, ela se levantava por volta 
das 8 ou 9 horas. Em geral, Iara ainda estava em casa e vinha servir Ceci, enquanto conversávamos sobre como havia sido a noite, como Ceci estava se sentindo ou o que Iara faria naquele dia.

A mesma movimentação, ainda nas primeiras horas do dia, podia ser observada nas casas vizinhas. Às vezes, eu ia comprar pão na vendinha da aldeia, por volta das 6 horas, e passava por diversas casas. Observava as pessoas voltando do banho no rio, carregando baldes de água, abrindo as janelas e varrendo as casas.

Após o desjejum, Iara ia para a beira do rio. No porto da casa, sobre a prancha - uma tábua de madeira suspensa na água quase na altura do quadril -, Iara lavava as roupas, as panelas, os pratos, os talheres e a louça.

Figura 2 - Mulheres da família extensa lavando roupas no porto

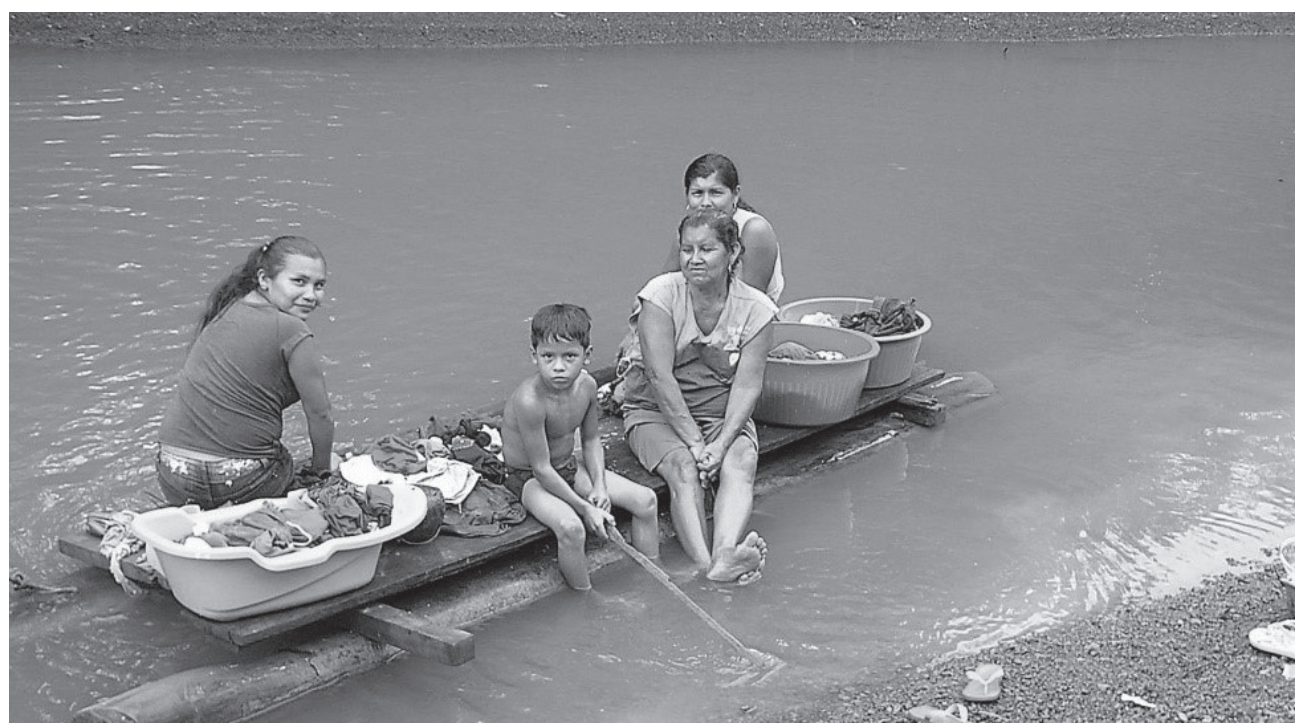

Foto Raquel Scopel.

$\mathrm{Na}$ aldeia Kwatá, cada família tinha seu porto, um espaço na beira do rio onde armavam a prancha, também de uso próprio, e onde aportavam a rabeta. Eu achava muito curioso observar que Iara escolhia lavar roupa nos mesmos dias e horários que as outras mulheres da família extensa. Assim, podíamos ver a paisagem à beira do rio ocupada pelas mulheres lavando roupas, acompanhadas de seus filhos menores, meninos e meninas, cada uma em sua prancha. À beira do rio, onde quatro famílias elementares, pertencentes à mesma família extensa de Ceci, tinham seus portos e pranchas, as mulheres podiam se ver e conversar enquanto lavavam roupa, pois os portos ficavam próximos. As crianças menores, com idade entre $4 \mathrm{e}$ 6 anos, se reuniam para juntas brincarem no rio. As crianças com mais de 7 anos, quando não estavam auxiliando suas mães a lavar a louça, também iam brincar e nadar. Louças e roupas eram transportadas sobre a cabeça em bacias de plástico ou 
metal de diversos tamanhos. As crianças com mais de 4 anos geralmente ajudavam a carregar as bacias, caso houvesse mais de uma. Jamais vi mulher alguma deixar roupa de molho na beira do rio. ${ }^{32}$ Elas voltavam para casa com as bacias carregadas de roupas e as estendiam em seguida no varal próximo da casa.

Essa sincronia nas atividades de lavar roupas se repetia na execução de outras atividades cotidianas, especialmente nos trabalhos de capina do terreno em volta da casa, de capina da roça ou na produção da farinha. Tais atividades podiam ocupar o restante do dia e, em geral, envolviam a participação de muitos membros da família elementar. Cada família elementar tinha uma roça própria. Responsáveis por capinar a roça e o terreno, as mulheres sempre o faziam acompanhadas de seus filhos.

Em um dia típico, podia-se ver Rita, após o desjejum, a caminho da roça seguida, em fila, por todos seus filhos menores, com idades entre 4 e 10 anos, e também por seu neto de 3 anos, filho de Isis. Todos seguravam uma faca ou um terçado, utensílio utilizado também para capinar. Naquele dia, quem cozinhou na casa de Rita foi Lisi, menina de 12 anos. Lisi era a filha solteira mais velha de Rita. Aliás, ela frequentemente cozinhava para toda a família, especialmente nos dias de trabalhar na roça ou de torrar farinha. Nesses dias, o filho de 11 anos do casal costumava ficar responsável pela pesca. Os homens também costumavam acompanhar suas mulheres durante a capina da roça, caso não estivessem pescando ou envolvidos com outro trabalho.

De fato, os homens e as mulheres Munduruku passavam boa parte do ano envolvidos nas atividades de plantação da roça, do fabrico da farinha, da pesca e da caça. Produziam os alimentos consumidos nas principais refeições com o trabalho na roça, na pesca e na caça. A roça era plantada em época certa, mas os cuidados exigidos, como a capina das ervas daninhas, eram quase semanais. A fabricação da farinha ocupava vários dias, desde a colheita até a torra. E o trabalho de torrar farinha podia ser feito até duas vezes por mês, a depender do consumo e da necessidade. Os cuidados com a casa eram diários, assim como as atividades de cozinhar e pescar.

O produto gerado pelo cultivo e torra da mandioca era a farinha, item que servia de acompanhamento nas refeições. Se, por um lado, os Munduruku podiam diversificar o tipo de carne consumida, devido à variedade de peixes no farto rio Canumã e eventualmente a uma caça bem-sucedida, por outro a farinha era um item constante nas refeições. Nunca vi uma refeição ser servida ou consumida sem a farinha para acompanhar. Certamente, a carne, em particular de algumas espécies de peixe ou de caça, era muito estimada pelos Munduruku. Não se concebia uma refeição sem carne, como veremos com mais detalhes na seção "Desejo e admiração" do Capítulo 3. Entretanto, uma boa farinha, torrada no ponto certo e na cor preferida, ao gosto do casal, também era muito apreciada. No fim das contas, segundo o paladar munduruku, uma refeição era composta de carne e farinha. A falta de qualquer um dos dois itens não era desejável. 
Cumpre lembrar que meu objetivo neste capítulo é fornecer uma descrição das atividades realizadas por homens e mulheres Munduruku ao longo dos dias, especialmente nos cuidados diários com a casa, com os filhos, enfim, na promoção da vida cotidiana e da vida familiar que sirva, especialmente, como contraponto para o leitor compreender as inversões ocorridas durante as práticas de autoatenção ao pós-parto. Outro objetivo é destacar que as performances cotidianas de apoio mútuo e de envolvimento nos trabalhos de produção dos alimentos colaboram para constituir o grupo familiar. Essas performances podem ser entendidas como um tipo específico de relação social, mobilizadas pelas práticas de autoatenção que proporcionam a reprodução biossocial do grupo familiar. Por esse motivo, passarei a descrever com mais detalhes as principais atividades cotidianas.

\section{A roça}

Todo casal possuía uma roça de mandioca. ${ }^{33}$ Alguns casais tinham também plantio de banana, de macaxeira, de cará e de melancia, entre outros tantos víveres. Todavia, a roça de mandioca ocupava lugar central na alimentação, pois é dela que se obtém a farinha de mandioca, item presente em todas as principais refeições. Ainda mais relevante, a plantação da roça de mandioca consolidava a união entre um homem e uma mulher Munduruku. De maneira geral, o casamento para os Munduruku coincidia com a abertura de uma nova roça de mandioca. Assim, a plantação da roça de mandioca despontava como atividade central na reprodução biossocial do grupo familiar. Além da abertura de novas roças, o envolvimento diário de homens, mulheres e crianças nos cuidados com a roça ou nas etapas de plantio anual permitiu também observar a constituição e a manutenção das relações sociais que agregam os indivíduos em grupos familiares, contribuindo para a reprodução das relações afetivas na família extensa e na família elementar por meio das performances de cuidados com a roça e de apoio mútuo.

Na família extensa na qual eu estava inserida, havia dois casais unidos recentemente. Um deles, Itapema e Iberê, havia se formado durante a última etapa da pesquisa de campo em 2011. O outro, Juciara e Roni, estava junto havia pouco mais de um ano. Ambos ainda residiam na casa dos pais das moças. No início do casamento, os genros contribuíram para alimentar a família de seus sogros e cunhados com o trabalho na pesca e na caça. Em certa medida, a dedicação e o sucesso do genro na pesca e na caça demonstravam sua habilidade como homem provedor, capaz de formar uma família. Todavia, além de contribuir para a nutrição da família, as ações dos genros também contribuíram para criar e manter os laços afetivos envolvidos no cuidado e apoio mútuo através das performances diárias do trabalho e do compartilhamento dos produtos desse trabalho cotidiano no interior das relações familiares. E o trabalho na roça consolidava esses laços afetivos. 
Itapema e Iberê estavam de resguardo do pós-parto enquanto moravam na casa dos pais dela. De fato, o casal havia acabado de ter o primeiro filho e o jovem marido estava terminando de construir a casa deles, na aldeia Kwatá, porém um pouco distante do segmento residencial no qual seus sogros moravam. A nova residência do casal ficava ao lado da casa da mãe dele. Todavia, ele pescava e caçava diariamente e os produtos de seu trabalho foram compartilhados por sua sogra entre outros membros da família extensa do sogro. A circulação do alimento, trazido por Iberê, feita em nome da mulher mais velha da casa, a sogra, inseria-os e reforçava uma rede de trocas no interior da família extensa. Enquanto isso, Itapema cumpria rigidamente a reclusão do pós-parto, as dietas alimentares e cuidava da filha recém-nascida. Ainda assim, Iberê colaborou no replantio da mandioca e na construção da casa de farinha de seus sogros.

Juciara e Roni tinham um filho com pouco mais de 1 ano de idade. O casal estava plantando a primeira roça em novembro de 2011. A roça do casal foi aberta num pedaço de terra que já fora "roça da minha mãe", conforme falou Juciara. Aliás, outras vezes ouvi homens e mulheres Munduruku se referirem à roça como propriedade da mulher. Assim, fora feito o convite para participar no puxirum (mutirão) da "roça da Iara" ou da "roça da Tainá", por exemplo. Em geral, os Munduruku da aldeia Kwatá abrem as roças em direção ao centro da mata e em oposição à beira do rio. Juciara e Roni abriram a "roça da Juciara" ao lado da "roça da Araci", sua mãe. No dia em que conheci a roça do jovem casal, Juciara havia saído para terminar de plantar algumas manivas (mandiocas) que já estavam cortadas quando ali chegamos. Ela obteve ajuda de duas irmãs solteiras, uma mais velha e outra mais nova, para plantar. A irmã mais velha cavava buracos na terra com a enxada, a mais nova colocava as manivas na cova e Juciara plantava, ou seja, ajeitava as manivas e jogava terra por cima, enquanto todas cuidávamos do filho de Juciara. Eu ajudei a plantar e percebi que éramos apenas mulheres trabalhando na roça. Essa observação era totalmente diferente de outra feita durante o puxirum da Iara, um evento especial marcado pela participação de muitas pessoas da família extensa na etapa da plantação da roça de uma família elementar. Juciara explicou que seu marido estava pescando. De fato, já havia muito trabalho feito, não estávamos começando uma roça, mas terminando de plantá-la. Pouco tempo depois chegou Pipira, o segundo irmão mais velho de Juciara. Ele assumiu a enxada que estava com a irmã mais velha e ela foi até a roça de sua mãe, ao lado, pegar outra enxada. Iniciamos o trabalho por volta das 15 horas e voltamos para casa por volta das 17 horas.

Enquanto estávamos plantando na roça de Juciara, seus pais estavam plantando na roça ao lado, a algumas dezenas de metros de distância. Itamar, esposo da Araci, estava com a enxada nas mãos, ela estava plantando com a ajuda de um filho pequeno. Tratava-se da roça de replanta, conforme explicaram. Todo casal possuía mais de uma roça, plantadas em períodos diferentes, de modo que, assim, retira- 
vam mandioca durante o ano todo. A mandioca levava dois anos para amadurecer e o processo do cultivo incluía diferentes etapas, conforme explicaram, nas quais foi possível observar uma divisão social do trabalho, constitutiva das relações de gênero e das relações etárias. Essas divisões tornavam-se observáveis por meio das performances individuais, de acordo com atividades específicas, que preenchiam expectativas sobre cada categoria social: homens, mulheres, crianças e velhos.

O trabalho de abertura da roça até a colheita da mandioca era feito em diversas etapas: derrubada, queima, plantio, capina e colheita. Ao observar essas atividades, identifiquei etapas em que ora os homens, ora as mulheres exerciam um papel específico. Entretanto, focalizando-se o conjunto de atividades na roça, nota-se que os homens e as mulheres se revezavam ou cooperavam na realização das diferentes etapas, de tal modo que ambos desempenhavam atividades importantes para a fartura da roça.

Na derrubada participavam apenas homens, cujo trabalho era a retirada dos troncos e galhos para a abertura de uma clareira delimitada para o plantio da roça. Em geral, os homens da família extensa colaboravam uns com os outros na derrubada e abertura da roça. O envolvimento nessa etapa implicava uma troca de serviços. Um homem que trabalhava um dia na derrubada da mata na roça de um parente podia contar com um dia de trabalho do parente em sua própria roça. O plantio era realizado após a queima, tanto no sistema de puxirum, envolvendo a participação de parentes da família extensa, quanto apenas por membros da família elementar. Depois do plantio, mulheres e crianças se dedicavam ao trabalho de capina das ervas daninhas que eventualmente cresciam na roça.

No trabalho na roça e, como veremos adiante, nas atividades de pesca, caça e na fabricação da farinha, observou-se uma divisão sexual do trabalho na qual se sobressaía o princípio da cooperação entre homens e mulheres, cada um contribuindo com uma atividade específica. Todavia, especialmente na roça, outras formas de divisão social do trabalho também operavam. A divisão sexual do trabalho era apenas mais uma das divisões sociais que organizavam as relações sociais de produção da roça, especialmente no trabalho coletivo do puxirum, no qual se destacava uma justaposição entre o trabalho de homens, mulheres, crianças e velhos (Scopel, 2013).

Eu e meu esposo Daniel participamos de um puxirum, isto é, de um trabalho coletivo na fase de plantio da roça. Scopel (2013) descreveu a realização desse puxirum, no qual analisou o trabalho coletivo como modo de acomodação das expectativas sobre os papéis a serem desempenhados por crianças, mães, pais, avós, avôs etc. Nesse puxirum, um homem e uma mulher mais velhos cortaram as manivas. Essa atividade envolvia um saber e uma prática adquiridos com o tempo, que lhes permitiam dimensionar a quantia necessária de manivas para o trabalho daquele dia. 
Figura 3 - Puxirum; mulher cortando manivas e criança juntando-as para distribuí-las nas covas

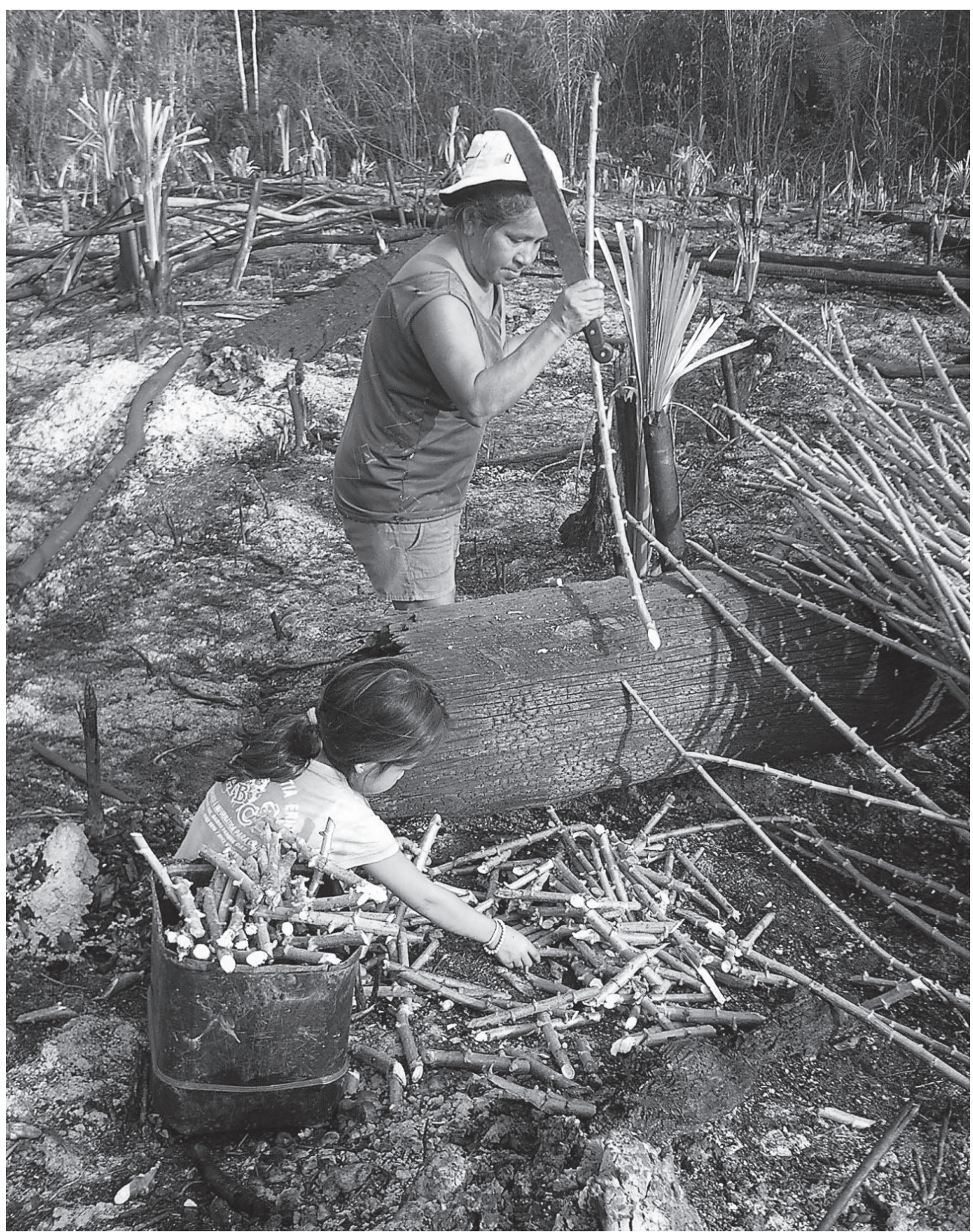

Foto Daniel Scopel. 
Figura 4 - Puxirum; homem cortando maniva e crianças juntando-as para distribuí-las nas covas

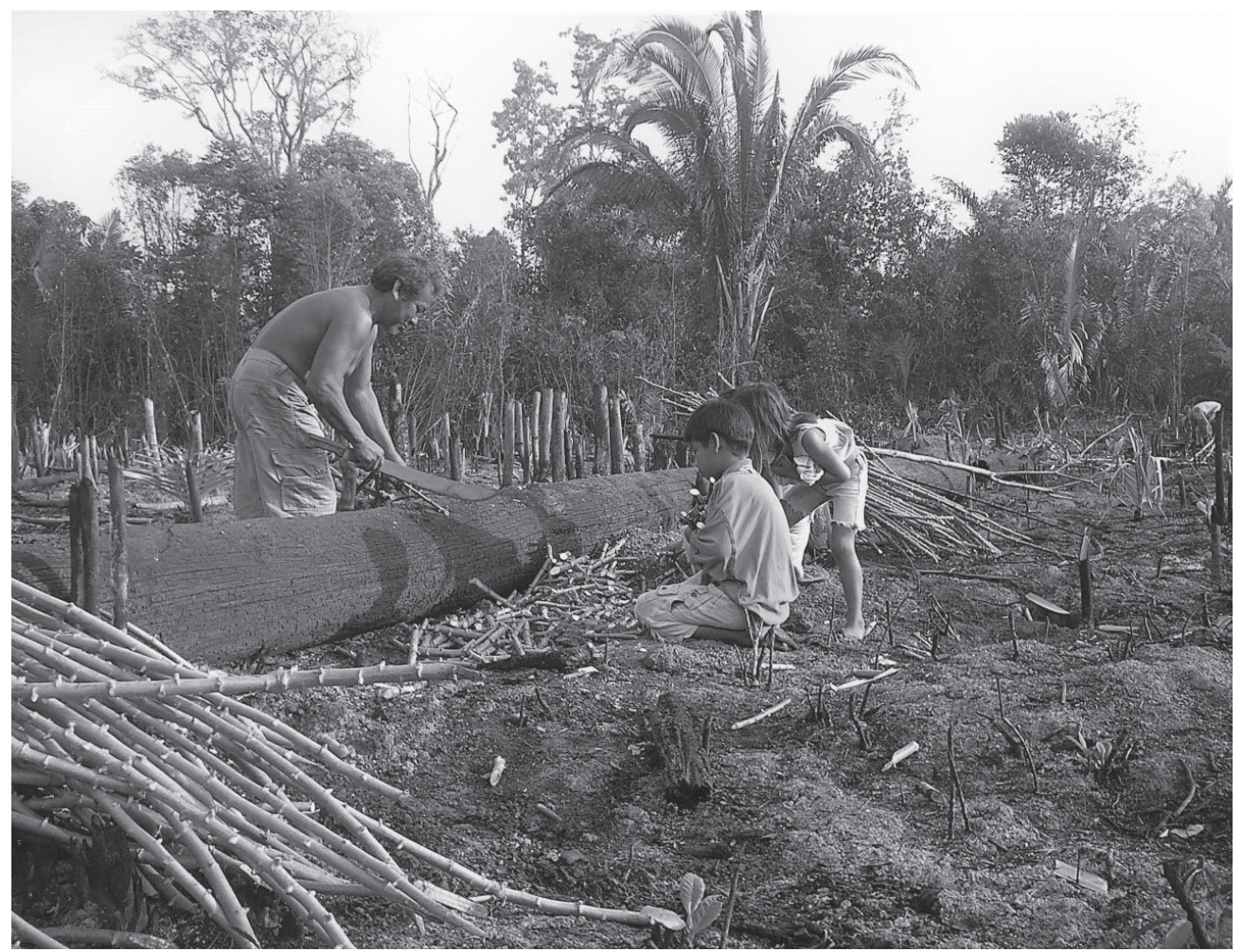

Foto Daniel Scopel.

Os homens, casados e solteiros, seguiram, lado a lado, abrindo buracos na terra com enxadas. As crianças, com idades entre 6 e 10 anos, se apressavam em carregar as manivas nos braços e jogá-las nos buracos abertos pelos homens. As mulheres casadas também seguiram lado a lado, endireitando as manivas nos buracos com os "olhos" voltados para a mesma direção, cobrindo-as de terra com as mãos.
Figura 5 - Homens cavando e crianças distribuindo manivas nas covas

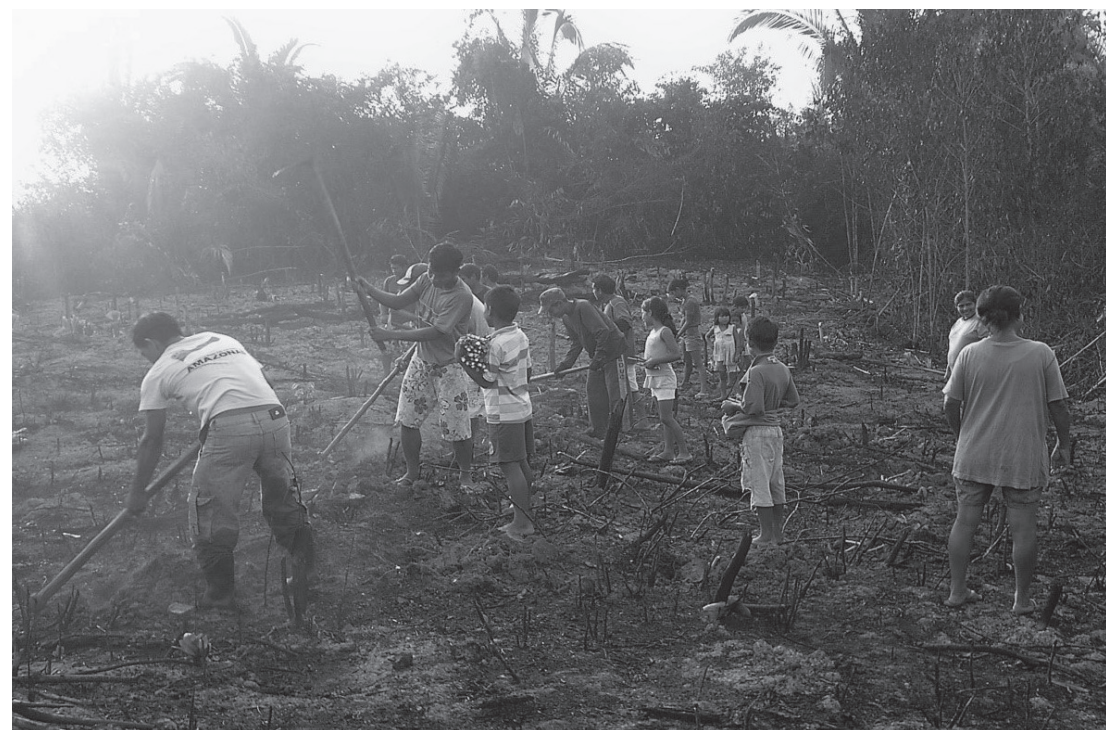

Foto Raquel Scopel. 
Figura 6 - Mulheres plantando manivas

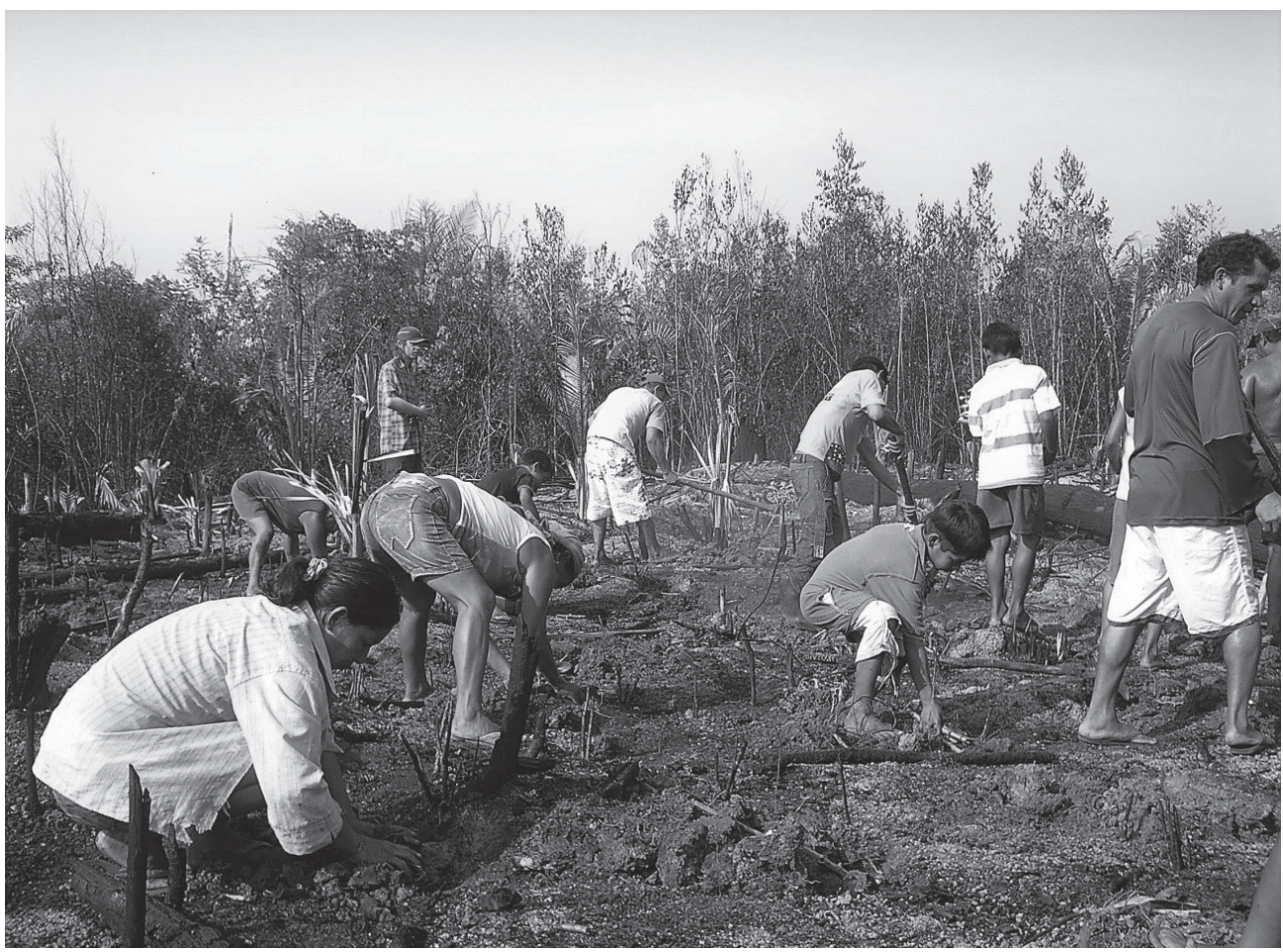

Foto Raquel Scopel.

As mulheres solteiras ficaram na aldeia auxiliando a dona do puxirum a preparar o almoço que celebrou o fim daquela jornada de trabalho. O puxirum também só se iniciou após uma refeição compartilhada ofertada pela dona da roça. Todos os participantes desse puxirum eram membros da mesma família extensa e residiam em um mesmo segmento residencial.

Segundo Scopel (2013: 135), a observação da performance cotidiana desempenhada nos trabalhos coletivos (por exemplo, no puxirum) permite sublinhar os processos através dos quais os indivíduos se inseriam em redes de apoio mútuo, colaborando na manutenção das relações de parentesco. O autor focou a aquisição de habilidades como etapa no percurso ou ciclo de vida do indivíduo que permite sua inserção em um "sistema de prestações totais", de trocas de mercadoria, mas também de serviços, nos puxiruns e de cuidados nos processos de saúde/doença/ atenção. A performance diária das habilidades adquiridas, conforme o autor destaca, contribui de forma decisiva para a construção e a manutenção dos laços sociais no âmbito familiar. E como veremos adiante, as performances de homens e mulheres nas práticas de autoatenção relativas à gestação, ao parto e ao pós-parto emergem no interior das famílias extensas e elementares ao mesmo tempo que conformam e reforçam as relações de parentesco, especialmente entre aqueles que cotidianamente se veem envolvidos nas relações sociais de produção e circulação dos alimentos. 
Figura 7 - Encerramento do puxirum com refeição coletiva ofertada pela dona da roça

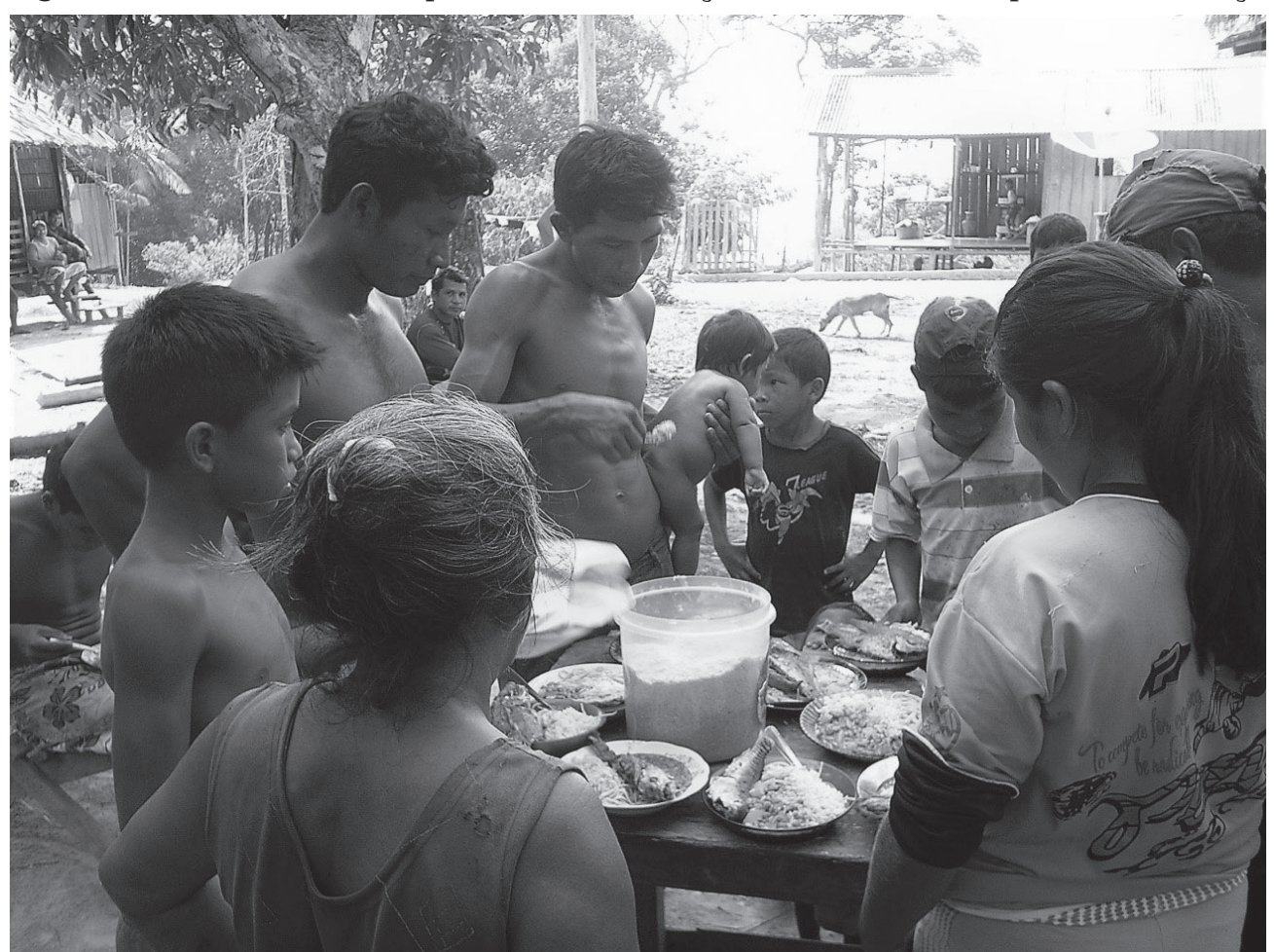

Foto Raquel Scopel.

A aquisição de habilidades como um processo aprendido na prática por meio da observação e da participação em atividades específicas demarca o modo de aprendizado constitutivo do corpo e definidor de agência, por meio das relações seja de gênero ou etárias. Embora essa seja uma assertiva teórica construída com base em diversos contextos, desde a Melanésia até entre alguns grupos panos amazônicos (McCallum, 1999; Pérez-Gil, 2007b; Strathern, 2006), os dados analisados por Scopel (2013) indicam que ela também se aplica ao contexto da vida e dos processos de aprendizado entre os Munduruku da Terra Indígena Kwatá-Laranjal (TIKL). Interessa-me ressaltar novamente a atuação das crianças no contexto do puxirum como produtoras ativas de comidas e de relações sociais ao adquirirem determinadas habilidades e se inserirem no trabalho cotidiano de cuidados com a roça, desde a performance nos puxiruns até a capina das ervas daninhas e a participação na fabricação da farinha. As habilidades performadas pelas crianças nas atividades relacionadas com a farinha, roça e torra, não constituíam distinções de gênero entre os adultos, mas sim etárias, pois se diferenciavam apenas em contraposição às habilidades performadas pelos adultos. Meninos e meninas se esforçavam em ritmo acelerado como se estivessem competindo para carregar o maior número possível de manivas no puxirum. Auxiliavam também na capina 
da roça e peneiravam a massa de mandioca na fabricação da farinha, mas não cavavam buracos na terra, não plantavam, não torravam a farinha nem cortavam manivas, atividades que exigiam habilidades específicas e performadas pelos adultos. Entretanto, os Munduruku costumavam dizer que algumas meninas eram iguais a "mulher velha", pois exerciam grande parte das atividades relacionadas aos cuidados com a casa e a alimentação. De certo modo, as habilidades adquiridas pelas crianças colocavam-nas em um circuito de responsabilidades, especialmente no interior da família elementar, e de trocas, na família extensa (Scopel, 2013). Entre os adultos, sim, a performance de determinadas habilidades, nos contextos da produção, circulação e consumo de alimentos, engendrava relações de gênero marcadas pela noção de complementaridade e pelo valor social da cooperação entre homens e mulheres. ${ }^{34}$ Neste livro, gostaria de sugerir que as habilidades complementares e a cooperação entre os agentes configuram algumas práticas e valores socialmente construídos com base nos quais as pessoas criam, passam a integrar e mantêm as relações de parentesco ao se envolverem nas atividades diárias de produção, circulação e consumo de alimentos (Viegas, 2003). ${ }^{35}$

Se por um lado a roça era a materialização da união de um homem e uma mulher Munduruku, assim como os filhos e a construção da casa, por outro o trabalho na roça também mobilizava as relações sociais no âmbito da família extensa. A sincronia nos trabalhos de plantio da roça se explica pela sazonalidade ideal para a tarefa. Há a época certa para plantar mandioca, de preferência entre os meses de março, abril e maio. É nesse período que são feitos muitos convites para participação no puxirum de algum parente ou dias de trabalho são trocados pela participação na abertura de uma clareira para a roça. Nesse sentido, podemos sugerir que a família extensa entre os Munduruku se alicerça também nas relações sociais de "trocas de serviços" envolvidos no curso da vida diária (Scopel, 2013: 125).

\section{A fabricação da farinha}

Foram necessários ao menos três dias para preparar a farinha para ser torrada. Após colher alguns tubérculos e descascá-los, separa-se uma parte para ficar de molho na água por um dia ou mais. Nesse dia, aproveita-se para descascar o restante dos tubérculos que serão misturados com aqueles postos de molho após serem ralados. Nas casas de farinha ou ranchos, onde participei dessa atividade, utilizou-se um artefato mecânico, movido a óleo e gasolina, para ralar a mandioca. Esta foi, sem dúvida, uma das etapas mais perigosas para torrar a farinha. Era preciso estar completamente atento para não ralar as próprias mãos, visto que o manuseio daquele equipamento não oferecia nenhuma segurança.

Embora eu possa dizer que fabricar farinha é uma atividade realizada, em geral, de forma separada, pelas famílias elementares que se utilizam do produto de 
suas roças particulares, houve momentos em que mulheres de diferentes famílias elementares se uniram para fabricar farinha. Houve também famílias elementares, casais jovens, com filhos pequenos que, sem terem ainda uma roça própria, fizeram todo o trabalho de colher, descascar, ralar e torrar a mandioca de um parente da família extensa para poderem usufruir de uma parte desse produto. Os Munduruku chamavam esse sistema de meia, isto é, o casal sem roça ficava com metade da farinha torrada por tê-la fabricado.

Ao longo das etapas necessárias para fabricar farinha foi se acentuando a divisão sexual do trabalho, nos casos de produção realizada pela família elementar. Vi tanto homens como mulheres coletando e descascando mandioca. Aliás, as crianças com mais de 6 anos participaram ativamente na etapa de descascar a mandioca. Outras crianças, com idades entre 4 e 5 anos, também ajudavam em algum momento, mas passavam a maior parte do tempo brincando em volta.

Figura 8 - Crianças descascando mandioca

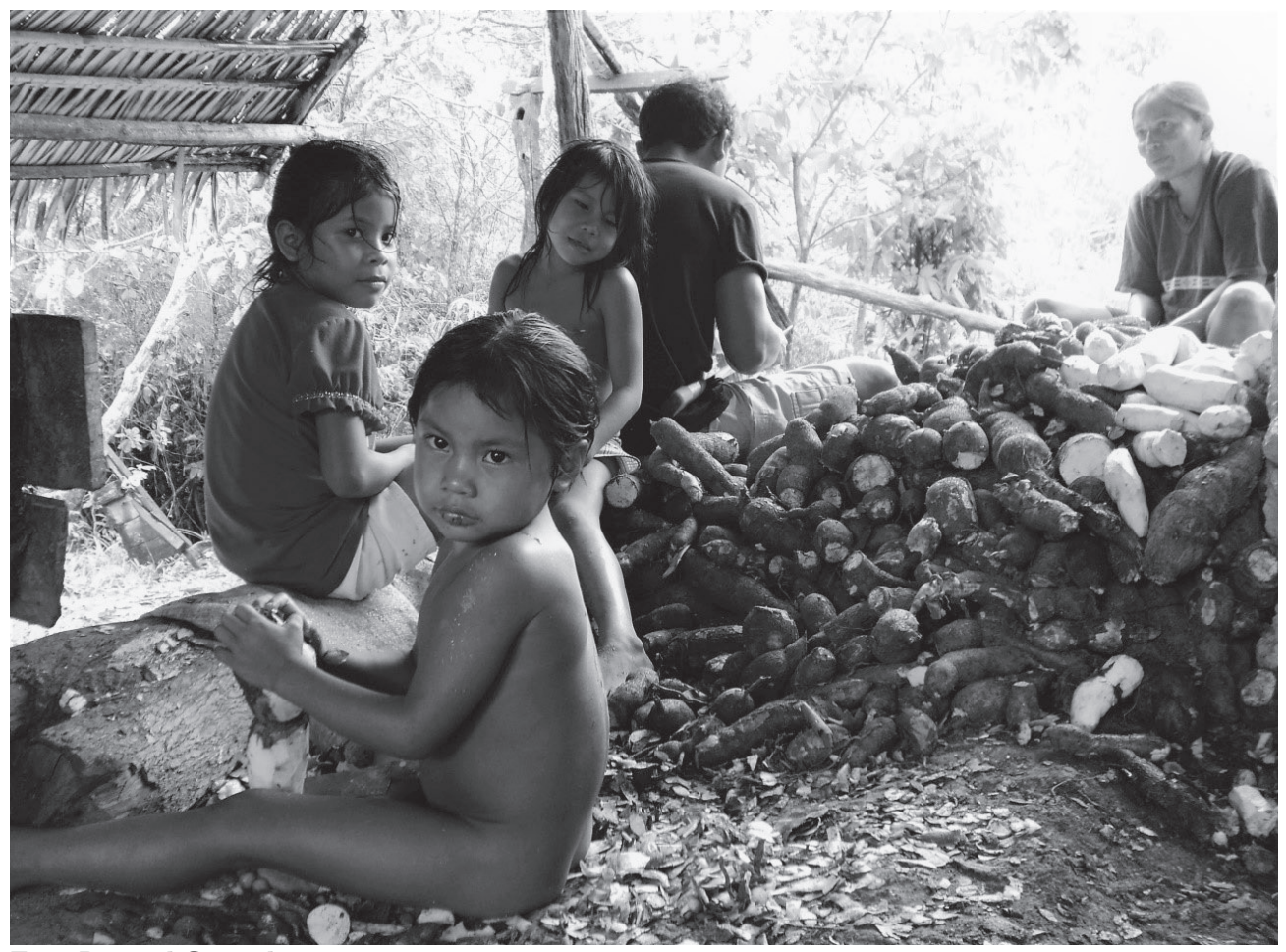

Foto Raquel Scopel.

Houve um dia em que três famílias utilizaram o mesmo rancho, onde havia dois tachos - esferas rasas, aparentemente de ferro ou cobre, dispostas sobre o forno de barro, onde se torra a farinha. Já comentei sobre a sincronia na realização de atividades cotidianas observáveis no trabalho da pesca, no plantio e nos cuidados com a roça e das atividades no entorno da casa. Naquele dia, estávamos 
na terceira semana após a semana dos Finados, quando os Munduruku evitaram passar pela roça e realizar certas atividades de trabalho, como fabricar farinha, sobretudo se tivessem ido ao cemitério para limpar o túmulo ou para acender uma vela no dia da "alumiação". Os Munduruku "resguardam", isto é, cumprem uma série de prescrições e restrições caso tenham ido ao cemitério ou a um velório. Mas esso é assunto para outro momento. Por ora, é suficiente salientar que aquelas três famílias haviam seguido o resguardo da semana dos Finados e o estoque de farinha estava chegando ao fim.

A casa de farinha era "da Iara". Havia dois tachos, um de Iara, outro de Ceci, sua mãe de criação. Iara havia acordado com seu irmão Zico, também filho de criação de Ceci, e com Dedé, genro de Zico, que eles poderiam utilizar sua casa de farinha. Zico e Rita, sua esposa, embora fossem um casal maduro, estavam construindo a própria casa de farinha e ganharam o tacho de Ceci. Dedé e Isis, sua esposa, eram um casal jovem, com dois filhos pequenos (o mais velho não tinha 3 anos), e ainda não tinham roça nem casa de farinha, por isso ambos utilizavam a casa de farinha da Iara. Naquele dia, enquanto Zico, Rita, Dedé e Isis estavam torrando farinha nos dois tachos disponíveis, Iara e Carlos estavam descascando as mandiocas para torrar no dia seguinte.

Figura 9 - Casal torrando farinha

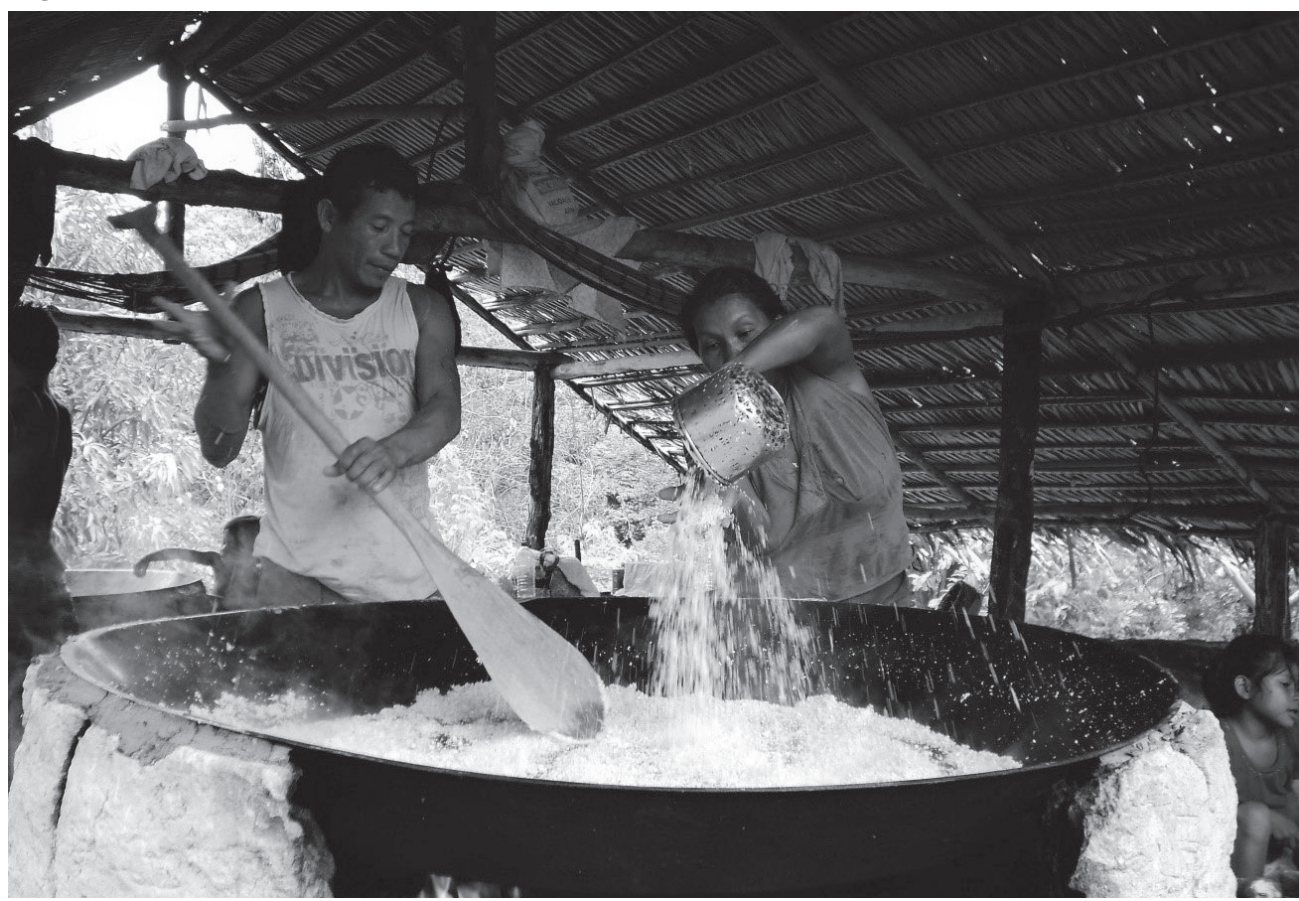

Foto Raquel Scopel. 
Figura 10 - Casal começando a descascar mandiocas

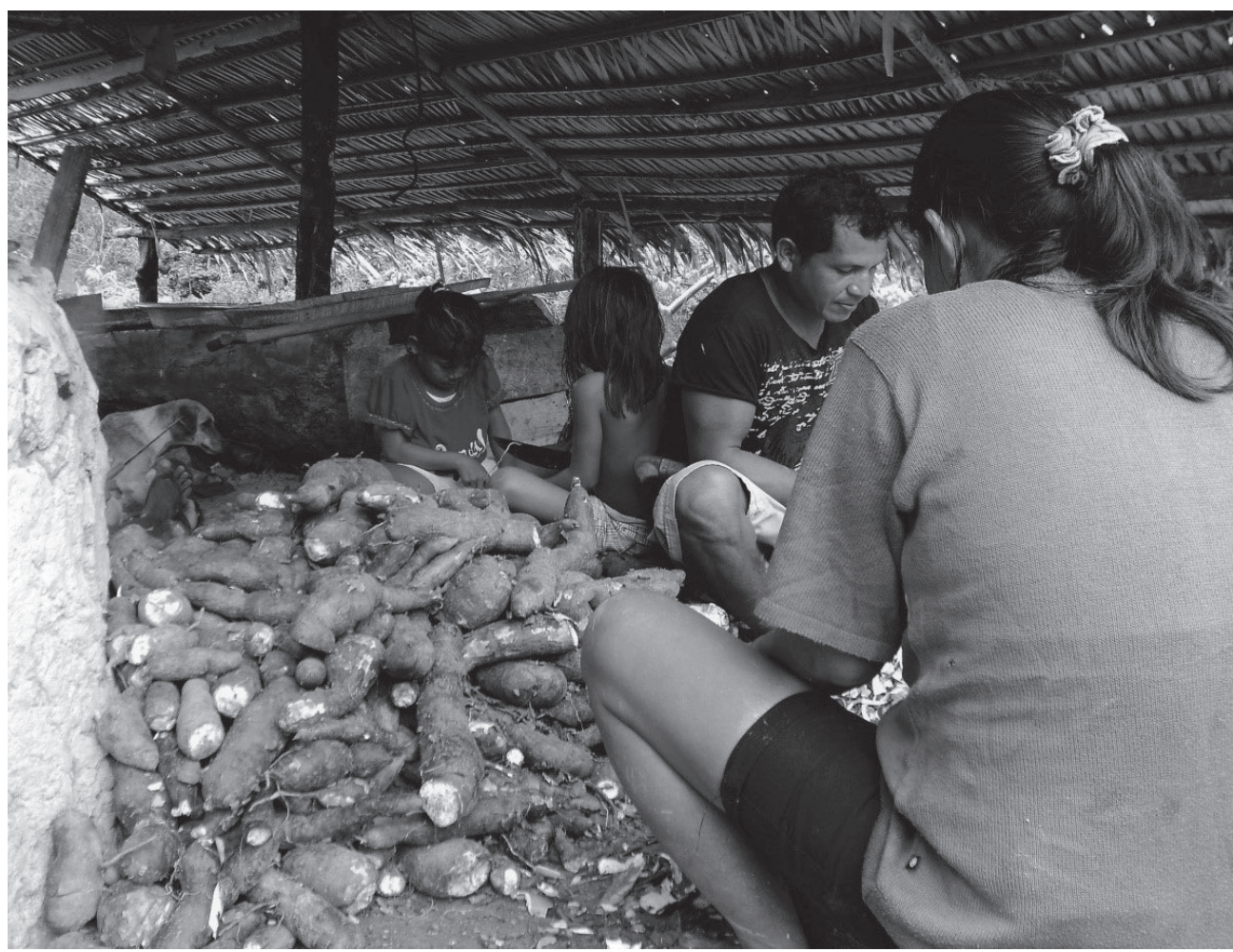

Foto Raquel Scopel.

Figura 11 - Casal descascando mandioca com o auxílio de membros da família extensa

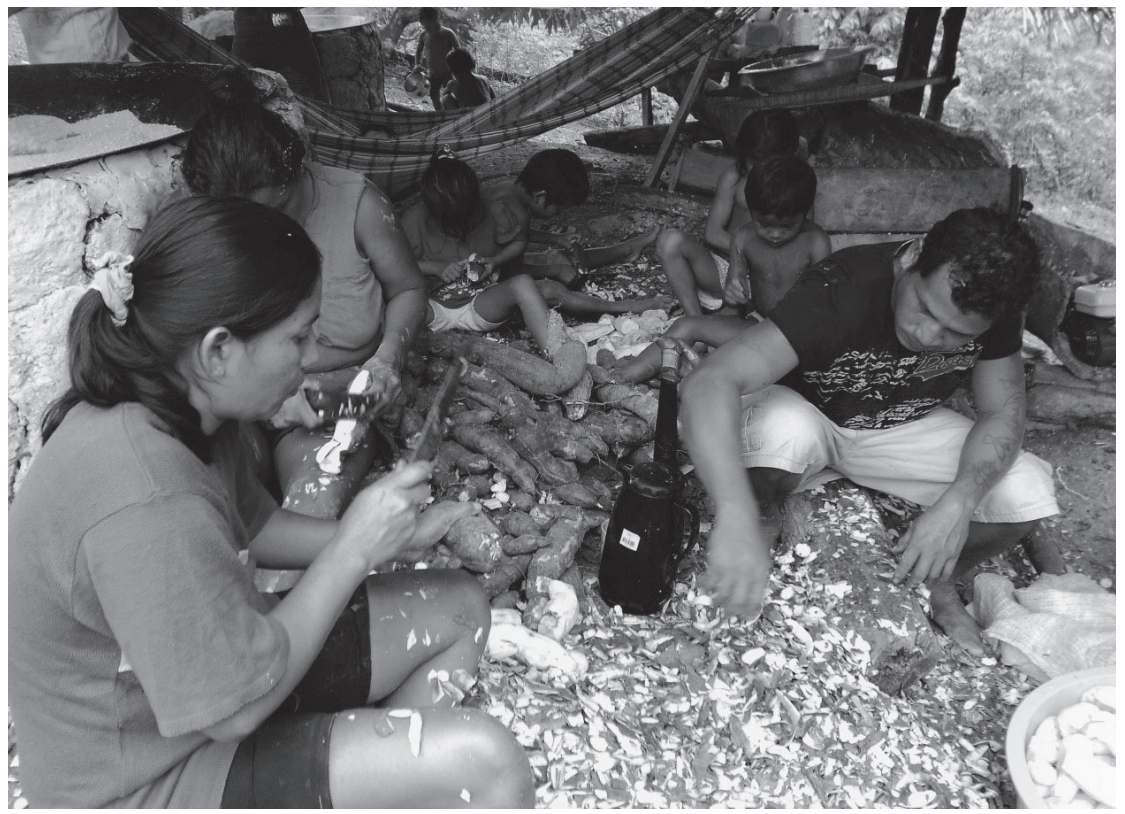

Foto Raquel Scopel. 
Figura 12 - Crianças peneirando a mandioca para ser torrada pela mãe

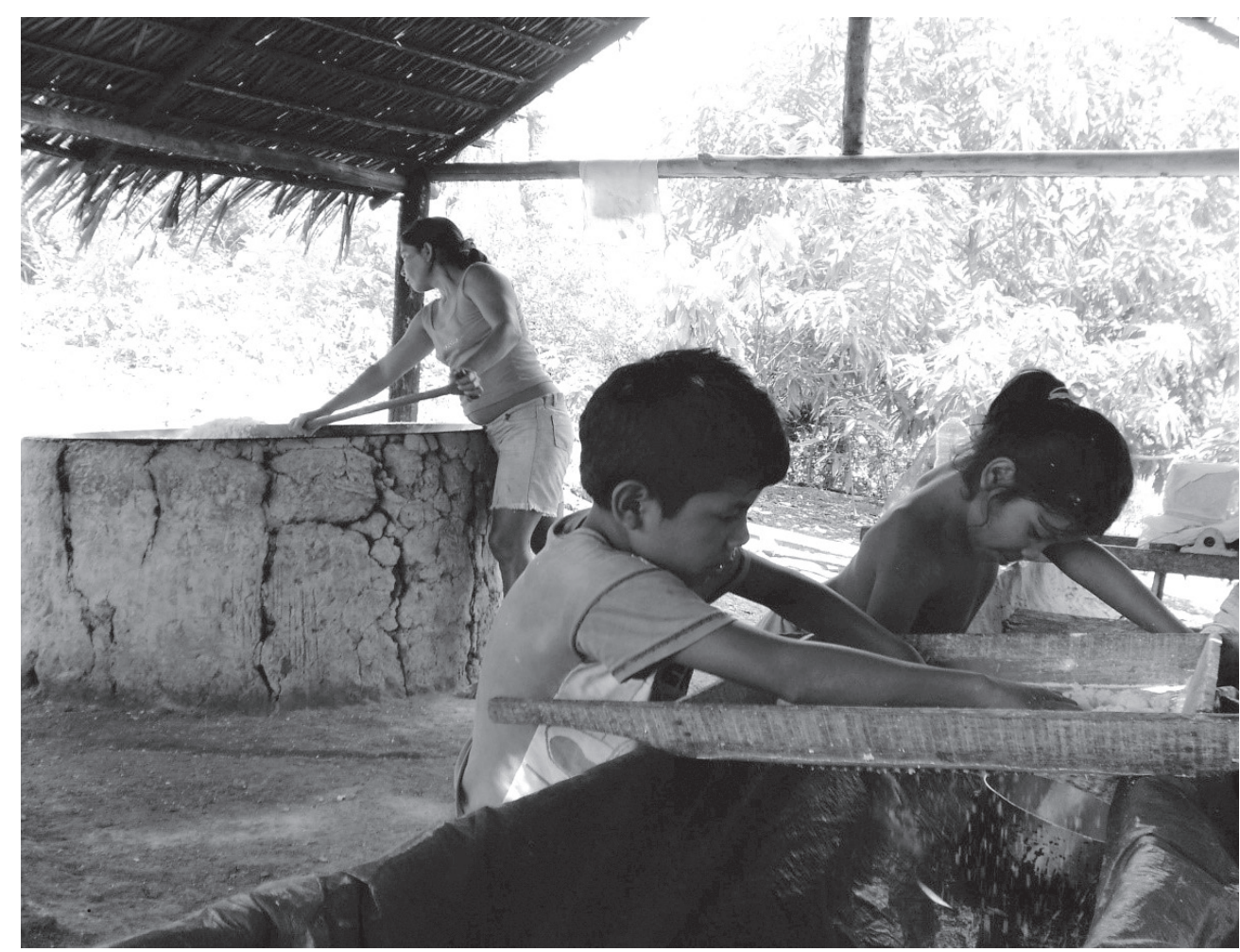

Foto Raquel Scopel

Na Figura 13, a seguir, apresento a genealogia da família extensa de Ceci, destacando em pontilhado as respectivas famílias elementares. As famílias elementares \#2, \#6, \#8 correspondem às famílias de Iara, Rita e Isis.

Eu acompanhava a família de Iara, uma de minhas anfitriãs, com quem compartilhava as refeições diariamente, notadamente sua farinha. Quando chegamos, por volta das 8 horas, Dedé estava usando o tacho de Ceci, torrando a farinha, enquanto Isis jogava sobre o tacho a farinha peneirada, além de cuidar de seu filho de apenas 4 meses. O bebê ficava na rede instalada para acomodá-lo, mas também recebia o colo das meninas mais novas, suas tias de 4 e 5 anos. Rita e Zico estavam terminando de preparar a farinha para começar a torrá-la. Rita e sua filha de 7 anos estavam misturando a mandioca molhada com a seca e peneirando-as. Zico se dedicava a encher o tipiti, espécie de espremedor feito de palha trançada que ao ser esticado prensa a mandioca molhada. A intenção nesse processo é retirar o restante do tucupi (líquido rico em ácido cianídrico), que se deixa escorrer pelo chão. 
Figura 13 - Genealogia da família extensa de Ceci

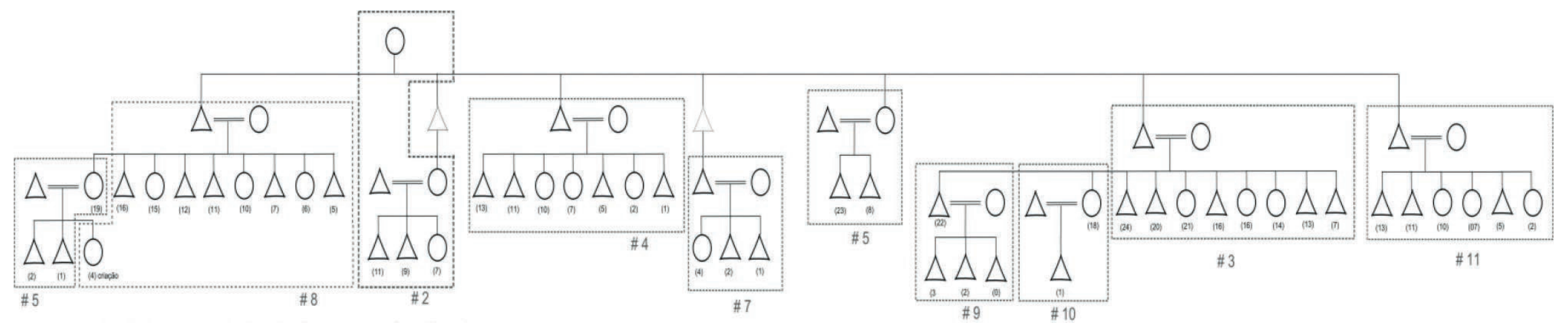


Figura 14 - Homem estendendo o tipiti

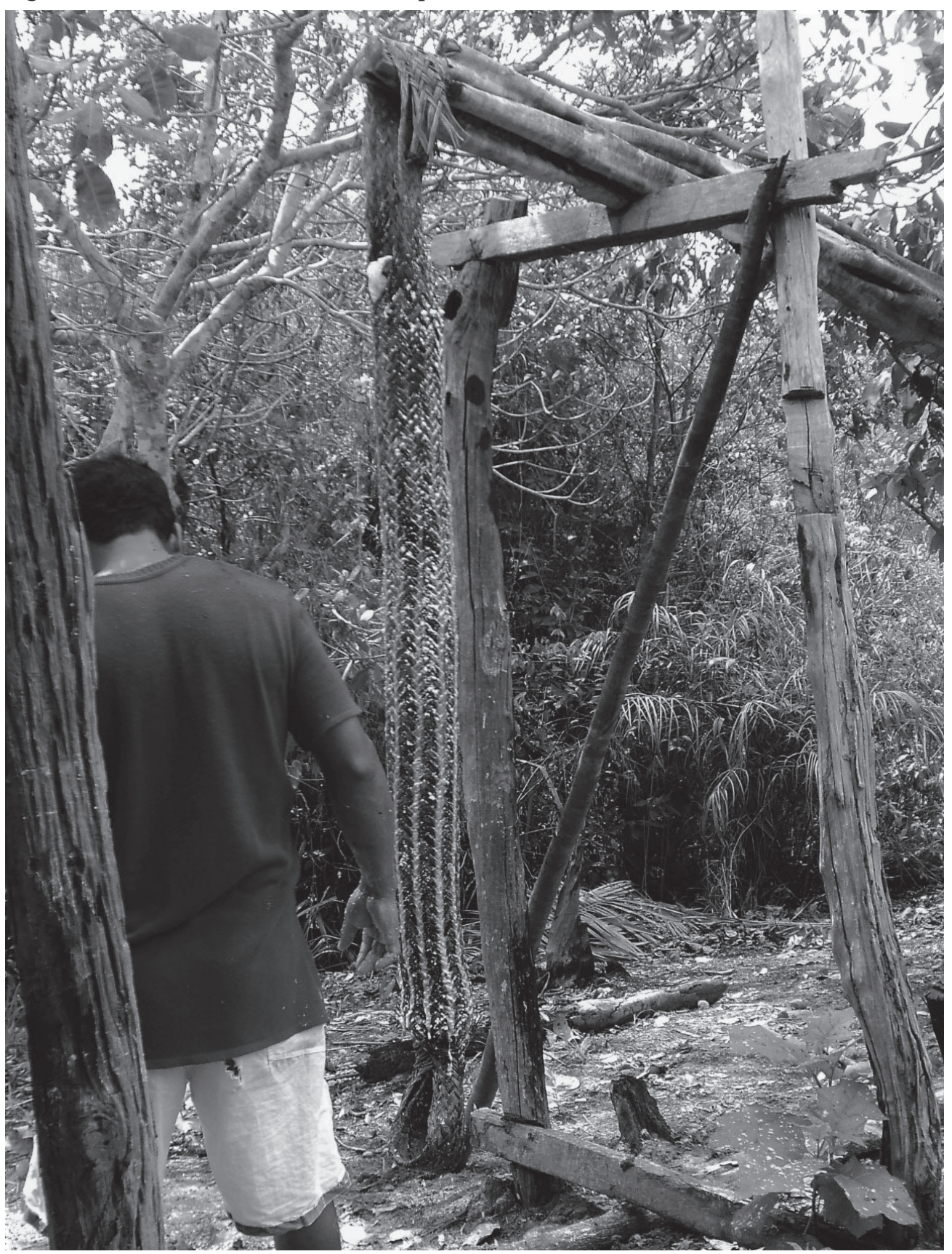

Foto Raquel Scopel.

Alguns casais utilizavam a goma formada do tucupi, após alguns dias de descanso, para fazer tapioca. Se a farinha era, majoritariamente, torrada pelos homens, a tapioca, por sua vez, o era pelas mulheres. 
Figura 15 - Mulher torrando tapioca

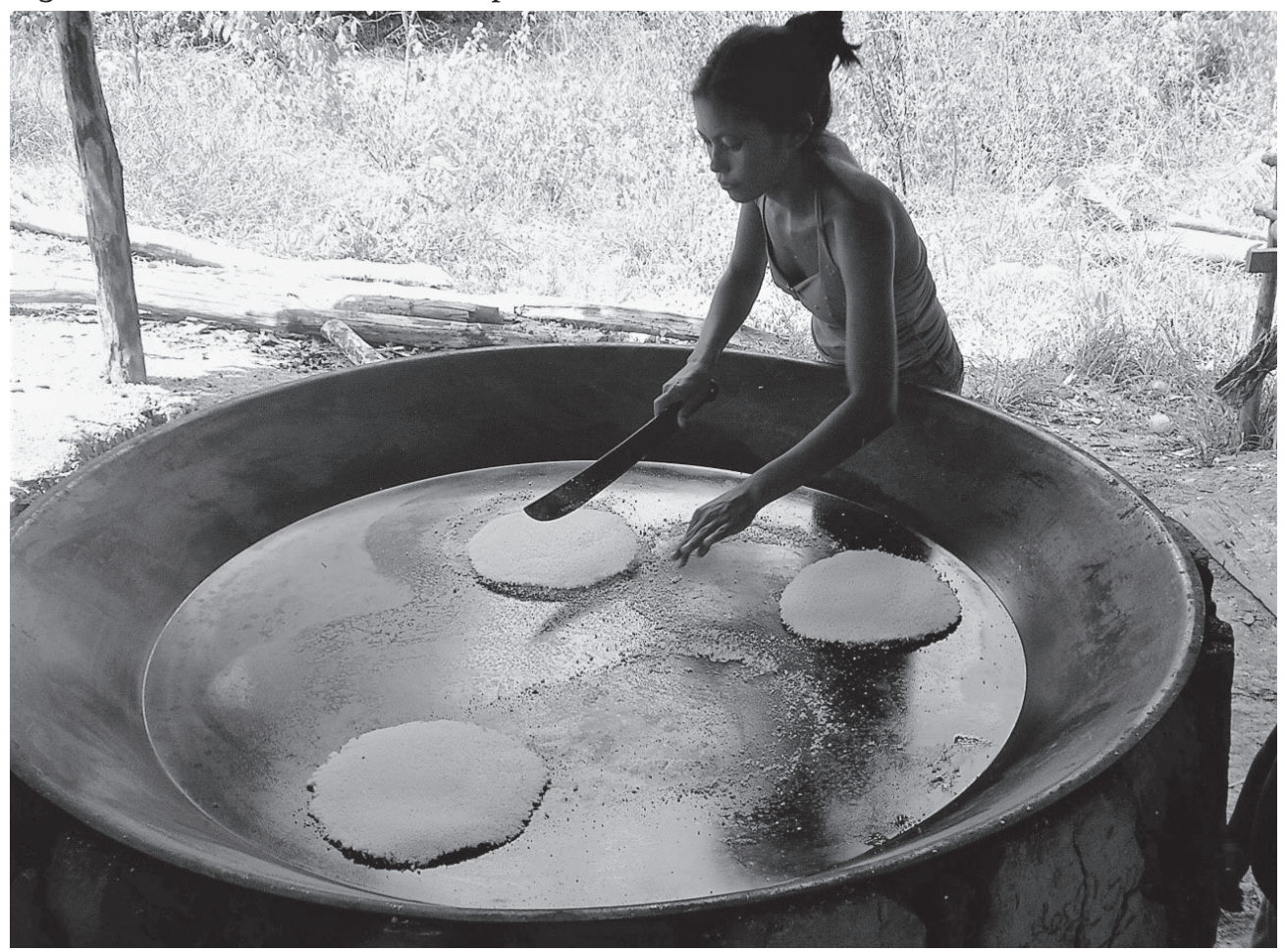

Foto Raquel Scopel.

Zico também buscou lenha e acendeu o fogo sob o tacho. Após pronta para torrar uma boa quantidade de farinha, Rita limpou o tacho já quente com um pano e um pouco de óleo e Zico assumiu a função de torrá-la. Isso era feito com remos, próprios para a torra. Rita jogava a farinha no tacho e Zico a mexia com o remo para torrá-la na medida certa, isto é, ao gosto do casal. Alguns gostavam dela bem amarela, outros um pouco mais branca, enfim, a cor da farinha conferia um sabor diferenciado segundo os Munduruku. A granulação da farinha peneirada também era algo particular, dependendo da peneira do casal, fabricada em geral pelo homem. Enquanto Zico torrava a farinha, Rita continuava a peneirar o restante da farinha crua. Rita só assumiu o remo, isto é, pôs-se a torrar a farinha enquanto seu marido foi novamente estender e retirar o tipiti. Assim que o filho mais velho do casal chegou, após a aula, por volta de $11 \mathrm{~h} 30$, ele assumiu as funções do pai no manuseio do tipiti e, em algum momento, do remo. O outro filho do casal, Zeca, de 11 anos, estava pescando.

Iara e Carlos estavam descascando os tubérculos, acompanhados de sua filha Nina, de 7 anos. O filho mais velho do casal, Raoni, de 11 anos, estava na aula e Raí, de 10, pescando, pois sua aula era apenas no período da tarde. Quando Rita terminou de peneirar toda a farinha que haviam separado, passou a auxiliar Iara. Naquele momento, os filhos e as filhas de Rita também se prontificaram e passa- 
ram a descascar a mandioca para Iara. Houve um momento em que as crianças de 3 e 4 anos também se esforçaram para descascar. É importante esclarecer que a participação das crianças foi voluntária. Não vi nenhuma mãe ou pai mandá-las trabalhar, embora as orientassem sobre a forma correta de fazê-lo e as advertissem sobre a necessidade de atenção no manuseio da faca.

Figura 16 - Crianças descascando mandioca

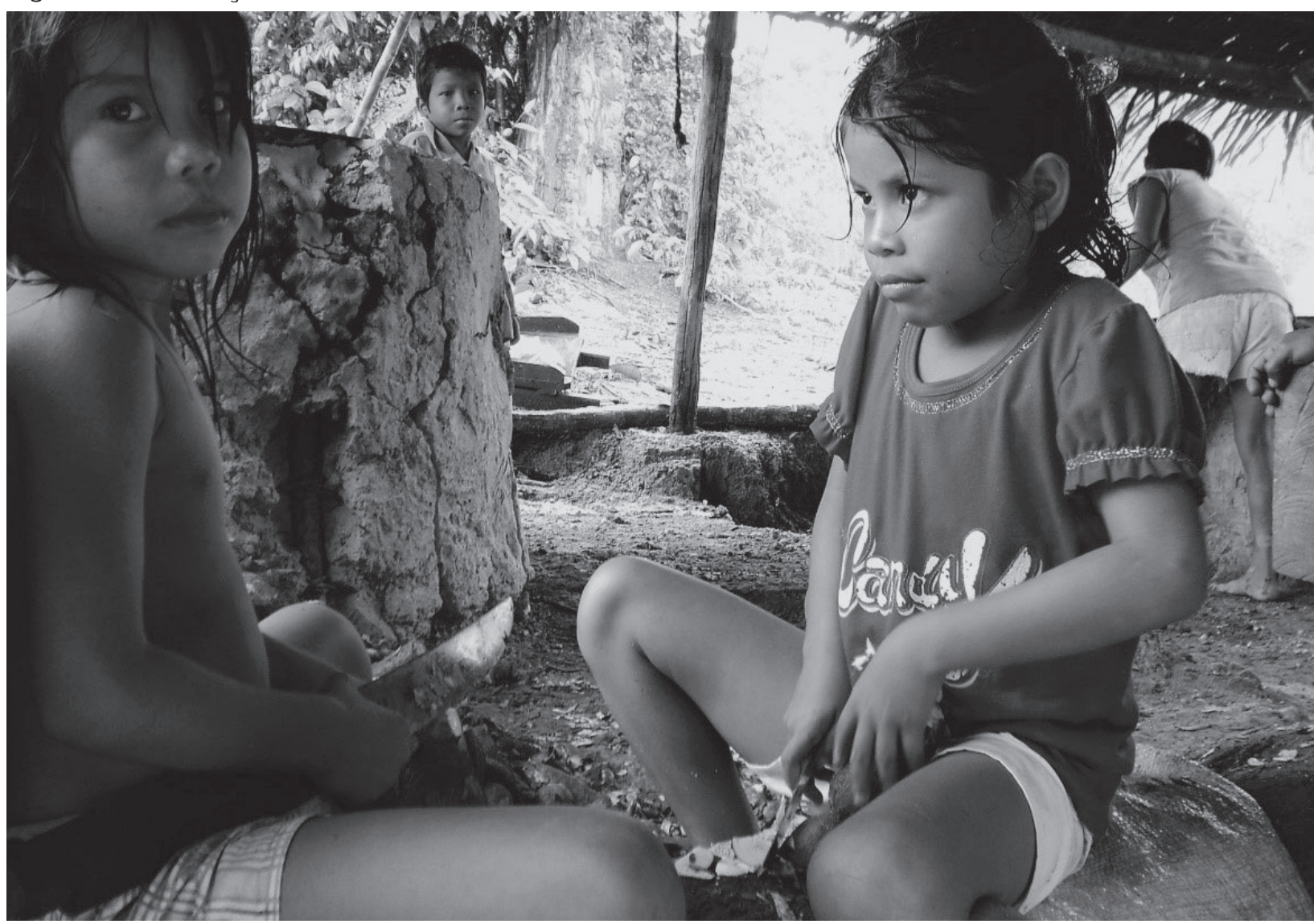

Foto Raquel Scopel.

De fato, as crianças menores, de 3 a 4 anos, rapidamente deixaram as facas para brincar ao redor da casa de farinha. Por volta das 13 horas, o filho da Iara que estava na escola chegou com alguns peixes pescados pelo irmão. Em seguida, chegou Zeca, filho de Zico e Rita, com um grande tucunaré que ele próprio havia pescado. 
Figura 17 - Menino com o tucunaré que pescou

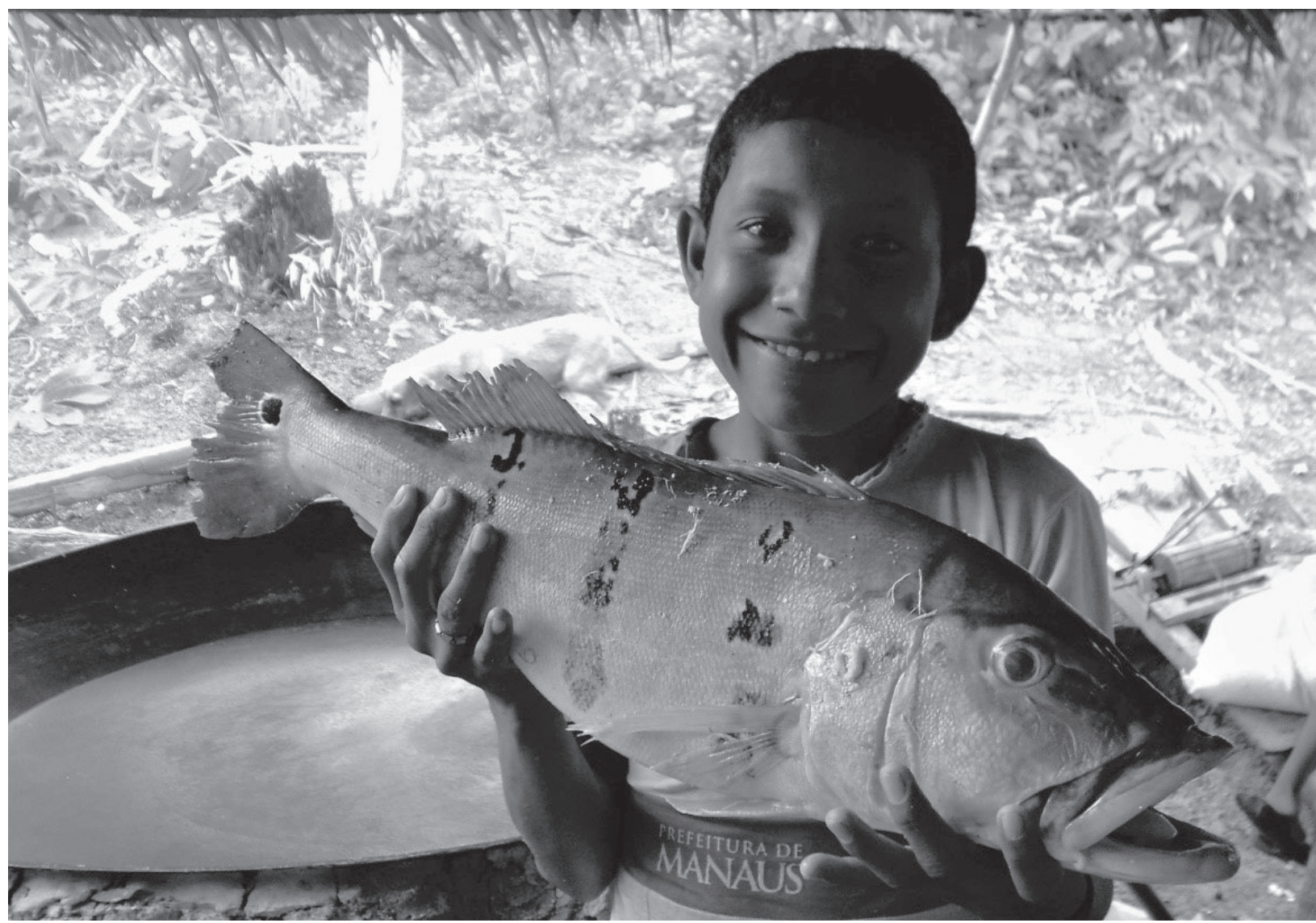

Foto Raquel Scopel.

A chegada das crianças com os peixes desencadeou um sentimento de grande euforia, marcado por risadas e comentários em voz alta sobre o modo como os peixes seriam preparados. Todos ali presentes estavam a ver o almoço chegar. Até aquele momento, só havia água e café para bebermos. Iara parou de descascar mandioca e foi imediatamente limpar os peixes para assá-los. Rita pediu ao filho que voltasse em casa e buscasse uma panela, pois decidira fazer uma caldeirada. Carlos, marido de Iara, providenciou os gravetos para o fogo e galhos para a grelha onde os peixes seriam assados. As famílias de Rita e Isis trabalharam naquele dia até aproximadamente as 17 horas. Iara, Carlos e seus filhos retornaram uma hora mais cedo.

O trabalho todo transcorreu envolto em uma aura de diversão, embora todos estivessem concentrados nas atividades. Havia muitas crianças em volta. Eram três famílias elementares trabalhando ao mesmo tempo, em um único espaço. Ora estavam engajados em uma única conversa, ora em muitas conversas paralelas. Criança chorando, brigando, rindo, correndo, trabalhando, enfim, um ritmo 
agitado. Isso ficou ainda mais evidente quando voltei no dia seguinte para torrar a farinha com a família de Iara. Nesse dia, o silêncio marcou a maior parte do tempo de trabalho. Estavam presentes Iara, Carlos, Nina, Raí e eu. O sistema de trabalho foi muito semelhante ao do dia anterior. Iara peneirando, com o auxílio de seus filhos; Carlos e Raí buscando lenha para o fogo; Carlos manejando o tipiti. A diferença mais marcante foi ver Iara tomar a frente e assumir durante a maior parte do tempo o remo para torrar a farinha, enquanto Carlos a jogava no tacho e a retirava. Talvez isso tenha acontecido porque Carlos não era Munduruku. Ele era da cidade de Maués. Ceci costumava dizer que ele era índio Maué. Carlos nunca negou.

No dia em que estavam as três famílias na mesma casa de farinha, a certa altura a conversa entre as mulheres girou em torno de um tema que merece ser destacado, pois remete a uma prática de formação do corpo e do caráter das crianças, o que, como veremos no próximo capítulo, se inicia desde a gestação. Ainda na parte da manhã, Iara passou a comentar com sua cunhada Rita o que estava projetando para seu filho Raoni quando ele "mudar de voz". Ela falou alto e todas as crianças ouviram, menos Raoni, pois estava na aula. Iara disse que ele iria cortar um "babaçuzeiro para não ter preguiça, para ter disposição". A palmeira de babaçu é relativamente grande, de tronco largo e duro. Certamente, Raoni terá de fazer um grande esforço para cortá-la quando chegar o momento. Muitos homens relataram terem cortado uma árvore grande apenas com machado e se lembravam do esmero necessário para cumprir até o fim aquela prescrição. Note-se que a intervenção sobre o corpo dos meninos parte de um sinal emitido pelo próprio corpo e interpretado pelos pais como uma mudança, "mudar de voz". Essa mudança sinaliza a hora de intervir sobre a formação do corpo e do caráter dos meninos. ${ }^{36}$

Perguntei se somente os meninos cortavam árvores e Iara contou que Ceci a fizera cortar um tucumanzeiro quando menstruou pela primeira vez. Aliás, ela lembrou que fez aquilo chorando porque seu irmão "ficava achando graça", e isso pode ser interpretado como a expressão de um comentário jocoso. Rita, então, falou-me que as mulheres "costumam mesmo" é se "resguardar". O interessante é que Iara sempre fora tida por seus irmãos como uma mulher muito ativa e que "trabalhava igual a um homem". Ao longo do livro veremos que o resguardo central direcionado às mulheres abrange práticas prescritivas relativas à menstruação e ao pós-parto. Há, no entanto, outros resguardos seguidos tanto por mulheres quanto pelos homens, como após ir ao cemitério ou a um velório, na Semana Santa ou na semana dos Finados, entre outros.

Por ora, gostaria de salientar que descrevi a fabricação da farinha para sugerir ao leitor que, apesar da divisão sexual do trabalho, é mediante esforços coletivos, cooperação e colaboração que os Munduruku produzem a farinha, isto é, homens, mulheres, jovens e crianças, embora em diferentes grau, contribuem como provedores de um dos alimentos centrais nas refeições diárias. 
É importante destacar que a organização social do trabalho aqui descrita é variável e que a cooperação entre homens e mulheres Munduruku é um valor socialmente construído. Por esse motivo, é interessante contrastar meus dados com os obtidos pelo casal Murphy (2004), entre os "índios Campineiros" Munduruku das savanas, com o objetivo de não naturalizar essa cooperação. Conforme observaram Murphy e Murphy (2004), entre os Campineiros haveria uma segregação entre mulheres e homens, organizados como grupos autônomos com ideais de cooperação e laços de solidariedade próprios a cada grupo. Mulheres e homens Munduruku que viviam nas savanas ocupavam espaços distintos na vida cotidiana e realizavam diferentes tarefas. Os homens habitavam na casa dos homens, onde dormiam, e eram responsáveis pela caça e pesca. As mulheres moravam nas habitações de suas mães, pois o padrão de residência era virilocal, tinham responsabilidades sobre a roça e a produção da farinha era exclusivamente realizada por elas. Todavia, seria errôneo supor que essa segregação fosse sinônimo de subordinação, pois, como observaram Murphy e Murphy (2004), embora a ideologia munduruku sublinhasse o antagonismo entre homens e mulheres e a superioridade dos homens, haveria um hiato entre a autonomia diária de cada grupo e a subordinação ritual e mitológica. Assim, na vida cotidiana, cada grupo teria uma autonomia e um poder de decisão sobre suas atividades. Além disso, os autores concluíram que, apesar de homens e mulheres conferirem maior prestígio aos produtos do trabalho de seu grupo, ambos eram necessários para pôr a economia em movimento. Ao observarem a vida diária, Murphy e Murphy (2004) notaram um desvio entre as normas coletivas e a prática individual do dia a dia, na qual coexistiam diferentes perspectivas dos homens e das mulheres.

Além disso, conforme sugerimos no capítulo anterior, quando migraram dos aldeamentos das savanas para as margens do rio Tapajós e seus afluentes, uma série de mudanças na organização social dos Munduruku teria ocorrido. Gostaria de assinalar a emergência da "família nuclear", nesse período, como uma unidade de produção e de residência e as mudanças na organização social do trabalho, em particular na divisão sexual do trabalho (Murphy G Murphy, 2004: 213). Ao visitarem as aldeias no rio Cururu, o casal Murphy (2004) observou a ausência da casa dos homens, os quais passaram a residir com suas esposas e a cooperar com as mulheres no trabalho na roça e na produção da farinha, vendida em grandes quantidades à época. A rígida divisão sexual do trabalho observada nos aldeamentos das savanas deu lugar a uma separação de tarefas particulares, que constituíam os esforços conjuntos de homens e mulheres na maioria das fases de produção da farinha. A autonomia dos grupos organizados em torno do eixo de gênero foi acrescida pela autonomia da "família nuclear", pois homens e mulheres compartilhariam as decisões que afetariam a família conjuntamente (Murphy $G$ Murphy, 2004: 225-226). 
Contudo, quando se observam práticas de autoatenção relativas à gestação, ao parto e ao pós-parto, nota-se que as atividades de apoio mútuo entre homens e mulheres no interior da família elementar são tão importantes quanto aquelas realizadas dentro da mesma família extensa. E, como veremos a seguir, assim como na roça e na fabricação de farinha, as atividades envolvidas na pesca, na caça, na preparação e circulação de alimentos, em certa medida, mobilizavam também as relações sociais de cuidado e apoio mútuo centrais para a manutenção das relações familiares.

Figura 18 - Irmão mostrando o fruto da pescaria feita pelo menino à esquerda da foto

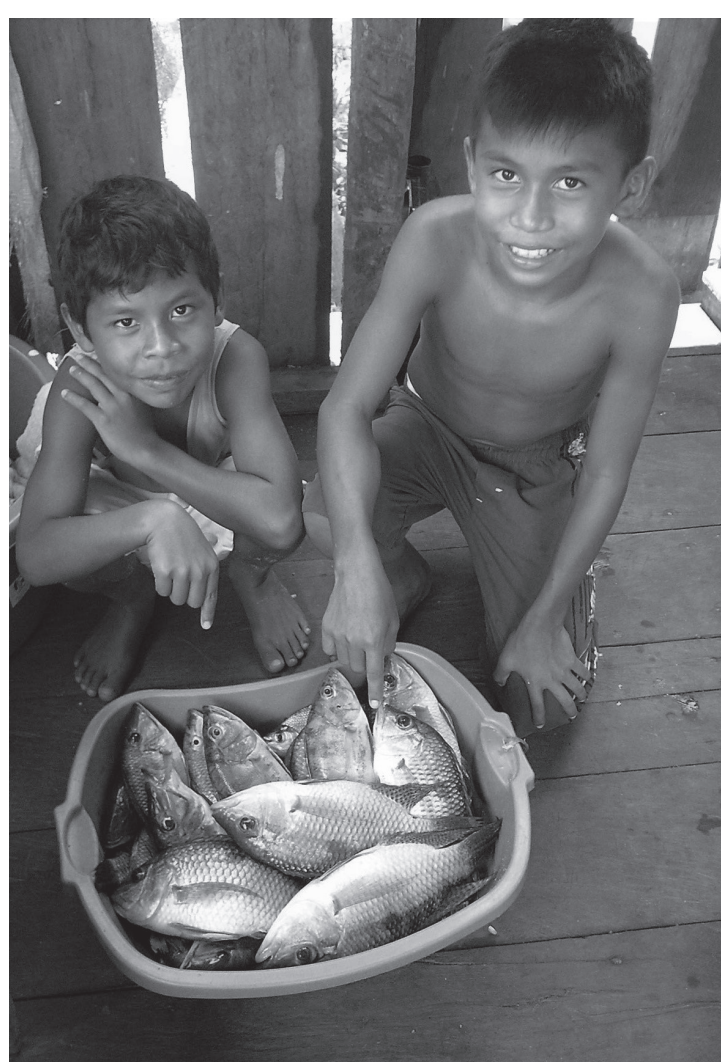

Foto Raquel Scopel.

\section{A pesca}

A pesca diária era uma atividade masculina entre os Munduruku. No cotidiano, os homens e meninos assumiram o trabalho de pescar e alimentar suas famílias. Para isso, utilizavam diversas técnicas para pescar conforme o tipo de peixe. Os utensílios para pesca incluíam desde rede de pesca e linha de mão até a zagaia, um tipo de arpão fabricado pelos Munduruku.

Os homens costumavam armar suas redes de pesca antes mesmo do amanhecer, ainda de madrugada. Saíam de canoa, armavam a rede nos igarapés e voltavam para casa no alvorecer. Passavam ainda madrugadas facheando, técnica de pesca com arpão e lanterna. Poucas vezes vi os homens saírem na parte da manhã, após o desjejum, para pescar. Nesse período, permaneciam por volta da casa e, muitas vezes, dedicando-se ao trabalho na roça ou no fabrico da farinha, junto com suas esposas e filhos.

A pesca diurna era feita pelos meninos com mais de 10 anos de idade, por vezes sozinhos, nos igarapés ao redor do porto de suas casas, sem ir muito longe. Na época em que Carlos estava trabalhando na construção da escola, houve dias em que seu filho Raí, de 10 anos, pescou com malhadeira (rede de pesca) nos igarapés próximos à sua casa uma quantidade de peixes suficiente para alimentar a família.

Os meninos jovens também pescaram para alimentar suas famílias nos dias em que seus pais e irmãos mais velhos estavam envolvidos no trabalho de 
torrar farinha. Raramente o homem adulto, em geral o pai na família elementar, não obtinha sucesso na pesca com a rede instalada no alvorecer ou no fachear da noite. Contudo, especialmente na época de cheia dos rios, quando ficava mais difícil pegar algum peixe, a solução era voltar a pescar durante o dia. Em geral, os meninos se dedicavam à pesca nesse período diurno.

A variação do nível das águas conforme a estação de seca ou de cheia tinha repercussão direta sobre a vida dos Munduruku, de modo geral, e nas atividades de pesca e caça, em particular. A estação da seca era época de fartura de peixes. A pescaria resultava em grandes quantidades e grande variedade de peixes. Nessa época, foi comum ver as mulheres Munduruku assando peixe na beira do rio, nas extensas porções de terra que a vazante das águas do Canumã fizera aparecer, para fazer piracuí (farinha de peixe). Dado o volume de peixes pescados pelos homens durante a época de maior fartura da seca, no início da vazante, o piracuí era a modalidade mais apreciada de conservação dos peixes por longo período. Na maior parte das vezes, cada família elementar se dedicava a assar os peixes e a fazer piracuí. Todavia, houve momentos em que diversas famílias se juntaram para assar uma grande quantidade de peixes. Todos se envolviam nas diferentes etapas de feitura do piracuí. Os homens pescavam; as mulheres, as crianças e os homens limpavam os peixes à beira do rio; as mulheres e as crianças juntavam os galhos para a feitura da grelha onde assariam os peixes, bem como coletavam a lenha para fazer fogo. Quanto maior fosse a quantidade de peixe pescado, maior a estrutura construída para assá-los. Assar os peixes foi uma atividade das mulheres.

Figura 19 - Mulheres assando peixes

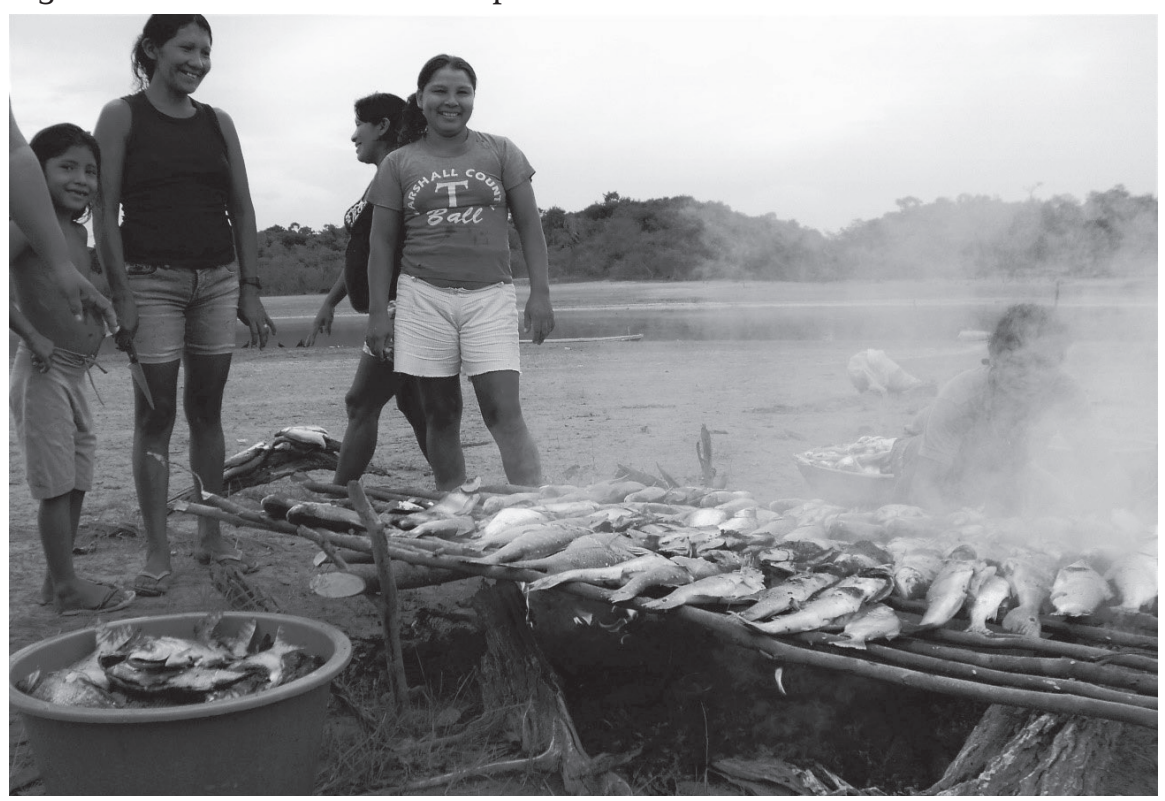

Foto Raquel Scopel. 
Isso tudo foi feito à beira do rio, em meados do mês de novembro, quando ainda havia praias nas margens. Depois de assado, alguns peixes eram imediatamente consumidos, outros guardados para as refeições seguintes e outros selecionados para a feitura do piracuí. Após o assado, as mulheres Munduruku separaram a carne da carcaça e das espinhas. A carne do peixe foi torrada no mesmo tacho (uma chapa grande de ferro) utilizado para torrar farinha, sobretudo pelos homens, embora algumas mulheres também tenham assumido tal atividade. A torra consiste em mexer continuamente a carne de peixe sobre o tacho aquecido no fogo a lenha. Durante o aquecimento, a carne de peixe desfiada recebe pitadas de sal. O produto final resulta em uma textura semelhante à de uma farinha de mandioca branca.

A caça

Vi apenas homens adultos voltando de caçadas. Em geral, caçavam à noite e sozinhos. No entanto, os homens Munduruku diziam que os rapazes jovens com mais de 16 anos já sabiam caçar. Em geral, os homens caçavam com arma de fogo.

Segundo Jim, um exímio pescador e também reconhecido caçador, as técnicas de caça variavam conforme o animal a ser caçado. A paca, por exemplo, era caçada à noite. Jim contou que ficava escondido, à espreita, aguardando a paca vir beber água na beira do rio para, então, dar um tiro certeiro. A anta também era caçada à noite. Conforme explicou Ney, morador da aldeia Niterói, a anta costuma comer um tipo específico de frutinha que existe na mata e deixa rastro de fezes. Assim, ele identificava a presença do animal durante o dia e voltava à noite para caçá-la. Ele contou que armava sua rede no alto da árvore e ficava lá aguardando o retorno da anta, que tem o costume de andar em círculos. Embora seja um animal grande, a escuridão da mata dificulta a precisão do tiro. Ney acertou um tiro na anta, mas como não foi certeiro, o animal conseguiu correr para a mata. Embora os homens Munduruku façam caçadas à noite, todos as consideram muito perigoso por causa da presença constante de onças naquela região. Por esse motivo, por muito tempo Ney não arriscou sua incursão sozinho, pela mata, à noite.

Iberê, um jovem recém-casado, passou o dia na mata e caçou uma cutia. Como já dito aqui, embora ele estivesse finalizando a construção da casa onde iria morar com sua jovem esposa, eles estavam cumprindo o resguardo do pós-parto e ainda moravam na casa dos pais da moça. Zico, sogro de Iberê, ao pegar emprestada a espingarda do genro, resolveu caçar nos dias seguintes e também trouxe um macaco-prego para a família. Ambos caçaram durante o dia e essa atividade os havia tirado por longas horas da vida na aldeia.

Os homens Munduruku não pescavam juntos, não facheavam em grupo, nem caçavam coletivamente. Todavia, pareciam fazer tudo isso ao mesmo tempo. 
Em conversa com os homens e mulheres Munduruku, aprendi que há remédio para tornar-se um "bom caçador": são banhos preparados com certas plantas especiais utilizadas para "puxar o braço", para ter mais precisão na mira. Jô falou de banhos antes da caça para tirar o "cheiro do caçador, cheiro de gente", com o propósito de evitar que o animal sinta o cheiro de gente e se afaste. Nete, uma mulher Munduruku, tinha uma horta próxima a casa, com muito "remédio para caçador". Ela me mostrou uma variedade entre cinco e sete plantas especiais para fazer banhos. Algumas dessas plantas eram utilizadas para preparar e formar um bom caçador, outras para afastar a "panemice" - de panema, conceito nativo que também se refere à má sorte na caça.

Nete cultivava uma horta com remédios para caçador incentivada por seu irmão que, durante a sua primeira gravidez, reclamou ter ficado com "panemice". Em geral, os Munduruku concordavam que uma mulher grávida pudesse deixar o caçador com "panemice", assim como a mulher menstruada poderia lhe trazer má sorte. A panemice podia se expressar na falta de sorte na caça ou na pesca ou como preguiça e fraqueza, e havia um vasto saber sobre como tratá-la. As práticas de autoatenção à "panemice" incluíam desde banhos, "puxações" (massagens), até ações como a mulher grávida morder a ponta da espingarda. ${ }^{37}$

Não observei nem ouvi relatos de práticas atuais de propiciação à mãe dos animais de caça ou à mãe da mata, ainda que estes seres fizessem parte da vida cotidiana dos Munduruku e que homens e mulheres mais velhos se lembrassem da época em que seus avós faziam fileiras com cabeças de animais de caça e lançavam "leite" de manicuera em direção à mata para agradar o espírito da mãe da mata e atrair muitos animais de caça. Entretanto, homens e mulheres Munduruku tinham o hábito de "pedir licença" para entrar na mata, para os donos dos lugares, pois diziam que "todo lugar tem seu dono e todo animal tem sua mãe". A relação com esses seres era mediada pela ética do respeito e pela cautela marcada pelo ato de fala ao se pedir licença. Pedir licença para a mãe da mata, da cacimba, do olho d'água, por exemplo, era uma forma/fórmula poderosa para evitar a vingança deles. Embora o respeito e a cautela para com as mães da mata, da roça, dos igarapés etc. não propiciassem maior fartura na caça ou na pesca, pedir licença garantia a saúde daquele que estivesse chegando. Desse modo, o sucesso da caçada residia na expertise alcançada por meio da prática, no conhecimento sobre os modos e hábitos dos animais de caça e, principalmente, nas ações intencionais sobre o corpo do caçador com a finalidade de formar um "bom caçador".

As caçadas bem-sucedidas resultavam na partilha do alimento. Houve distribuição de partes do animal caçado mesmo quando a presa era um animal pequeno, como no caso de uma cutia ou um macaco. A família de Zico, com 13 pessoas, por exemplo, compartilhou parte do animal com os vizinhos da mesma família extensa. Todos os parentes da família extensa que compartilhavam o mesmo núcleo 
residencial ficaram sabendo quando Zico havia tido sucesso na caçada. Algumas mulheres da família extensa foram até a casa do caçador pedir à mulher dele um pedaço da caça e ganharam. Não foram todas as mulheres da família extensa que pediram, mas aquelas que o fizeram ganharam um pedaço. O sucesso na caça ou na pesca, embora não fosse sinônimo de quantidade, resultava na partilha de alimento entre membros da família extensa.

\section{A preparação dos alimentos: cozinhar}

Um dia Zico chegou da caça com um macaco guariba. Várias pessoas da família extensa foram até a casa dele para ver o macaco morto, inclusive eu. Toda a sua família estava na varanda da casa observando o animal com curiosidade. As crianças estavam muito eufóricas e brincavam com o corpo do animal. Zico perguntou se eu poderia fazer uma fotografia dele com a caça. Fiz a fotografia e lhe entreguei alguns meses depois. Tão logo fizemos a fotografia, seus filhos mais velhos prepararam o fogo para queimar os pelos do macaco no terreno ao lado da casa. A mãe das crianças os auxiliava da cozinha da casa, que ficava na varanda. Depois que retiraram os pelos, Rita, esposa de Zico, limpou as vísceras, retirou as unhas, dentes e cortou o animal em pedaços. Ela preparou um cozido com a carne e mandou-me uma porção em retribuição à foto tirada.

Muitas vezes, pela manhã, os netos e as netas de Ceci traziam-lhe peixes. Iara era responsável pela limpeza e cozimento dos peixes na casa de Ceci. Tão logo retornava da roça, por volta das 10 horas da manhã, iniciava o trabalho na cozinha. Ela preparava os peixes que Ceci ganhava, assim como aqueles pescados pelo marido e pelos filhos.

Se a pesca e a caça eram atividades masculinas, cozinhar era uma atividade do rol das mulheres. As cozinhas das casas eram equipadas com fogão a gás e algumas panelas de alumínio, areadas com muito esmero pelas mulheres, que as deixavam com um brilho especial. Tinham também fogão a lenha feito de barro no quintal. No dia a dia, limpavam os peixes, tirando as vísceras e as escamas, caso necessário, e os preparavam para as refeições.

Os peixes e as carnes de caça eram preparados de diversas formas. O modo de preparo mais apreciado era, indubitavelmente, o assado. Esta modalidade, entretanto, era feita exclusivamente fora da casa, em uma grelha construída pela própria mulher para cada assado. Elas eram também as responsáveis por coletar a lenha, tarefa em que as crianças ajudavam. Os Munduruku também apreciavam a caldeirada de peixe, um modo de preparar o peixe cozido com muita água e temperos cultivados no terreno de casa, especialmente cebolinha verde e coentro, com pouco sal, alho, açafrão e pimenta-do-reino em pó, comprados nas vendas na cidade. 
Outro modo de preparo dos peixes era a fritura no óleo. Nas épocas de fartura de peixe, normalmente Iara preparava mais de um tipo de prato por refeição: caldeirada, assado e frito. Do mesmo modo que os meninos participavam da atividade de pesca, podendo em algumas situações pescar para alimentar toda a família, especialmente nos dias de fabricação da farinha, também as meninas com mais de 12 anos já cozinhavam para toda a família.

A circulação dos alimentos era feita por mulheres, entre os Munduruku. Os homens entregavam o peixe ou a caça para a mulher ao retornarem para casa e ela tratava, limpava, cozinhava e distribuía porções entre alguns parentes. Observei que a circulação de alimentos produzidos pela caça ou pela pesca era feita tanto no estado cru como após o cozimento. E, na maioria das vezes, as crianças levavam o prato com o pedaço de carne ou com a refeição já pronta até a casa dos parentes. A entrega era sempre em nome da mulher do caçador. Lembro, por exemplo, nos dias em que ganhei porções de paca, de macaco, de cutia e de peixes, as crianças chegarem até a casa onde eu estava morando e falarem: "Oh, dona Raquel, mamãe mandou para você". Também era recorrente ouvir ou receber das crianças os alimentos entregues para Ceci, nossa anfitriã: "Mamãe mandou trazer para a vovó Ceci".

Gostaria de sugerir que a circulação de alimentos é tão importante quanto a produção de alimentos para a manutenção das relações familiares e, nesse caso, as agências masculinas e femininas são complementares. Ao observarmos a circulação dos alimentos, o foco sai da ação individual e de seu impacto na família elementar e repercute nas relações sociais que mantêm os laços de cuidado e apoio mútuo na família extensa. Sobre as relações de parentesco entre os Munduruku da TIKL, é relevante ter em mente ainda a sugestão feita por Scopel (2013: 125):

Esse compartilhamento de substâncias, frequentemente observáveis como compartilhamento de alimentos - no qual podemos incluir todo o circuito de trocas desde fluídos corporais até cuidados e serviços - definem relações de parentesco, as quais conectam o corpo individual ao corpo social num ciclo dinâmico de atividades cotidianas.

De certo modo, homens, mulheres e crianças, a partir de certa idade, contribuíam ativamente nas práticas diárias de produção e circulação dos alimentos. As pessoas mais idosas, em geral, não tinham mais roça e já não trabalhavam mais na produção de alimentos. Todavia, os idosos podiam contribuir de forma ativa fazendo circular as mercadorias e os gêneros alimentícios adquiridos com a aposentadoria. O engajamento diário nas atividades de produção, circulação e consumo dos alimentos, bem como nas atividades de cuidado com a casa e com as crianças, fazia parte do conjunto de atividades em torno das quais as famílias se estruturavam e por meio das quais mantinham as relações de afeto e reciprocidade (Gow, 1989; Viegas, 2003; Scopel, 2013). 


\section{Trabalho assalariado e trabalho por "diárias"}

Diversas pessoas tinham trabalhos assalariados na aldeia Kwatá. Eram professores, agentes indígenas de saúde, de saneamento e microscopia. Essas pessoas, em geral, coordenavam as atividades de seu trabalho assalariado com o trabalho de roça, caça ou pesca. Durante a segunda e terceira etapas da pesquisa de campo, outras atividades de trabalho pago com diárias haviam ocupado os homens Munduruku dessa aldeia.

Considero relevante relatar algo sobre o trabalho dos homens remunerados por diárias em obras que aconteceram na aldeia, pois a participação deles acabou tendo impacto sobre a alimentação da família e as práticas de resguardo do pós-parto. Neste caso, ou porque o pai do recém-nascido havia deixado de cumprir o resguardo do pós-parto para trabalhar, o que repercutiu diretamente sobre o estado de saúde do bebê, ou porque havia se ausentado do trabalho para cumprir o resguardo e auxiliar a esposa em reclusão, como veremos em detalhes no Capítulo 7.

No final de 2010, alguns homens Munduruku trabalharam na finalização da nova instalação da rede elétrica que passou a atender toda a aldeia. Até aquele momento, um gerador a diesel provia energia elétrica aos moradores da aldeia Kwatá, apenas durante poucas horas ao anoitecer. A Prefeitura de Borba fornecia uma cota de combustível, sempre insuficiente para o uso mensal dos Munduruku. Isso resultava na mobilização dos moradores para contribuir com algum dinheiro com o propósito de comprar diesel para reabastecer o gerador até a chegada da cota de combustível do mês seguinte. 
Figura 20 - Homens trabalhando na instalação da rede elétrica

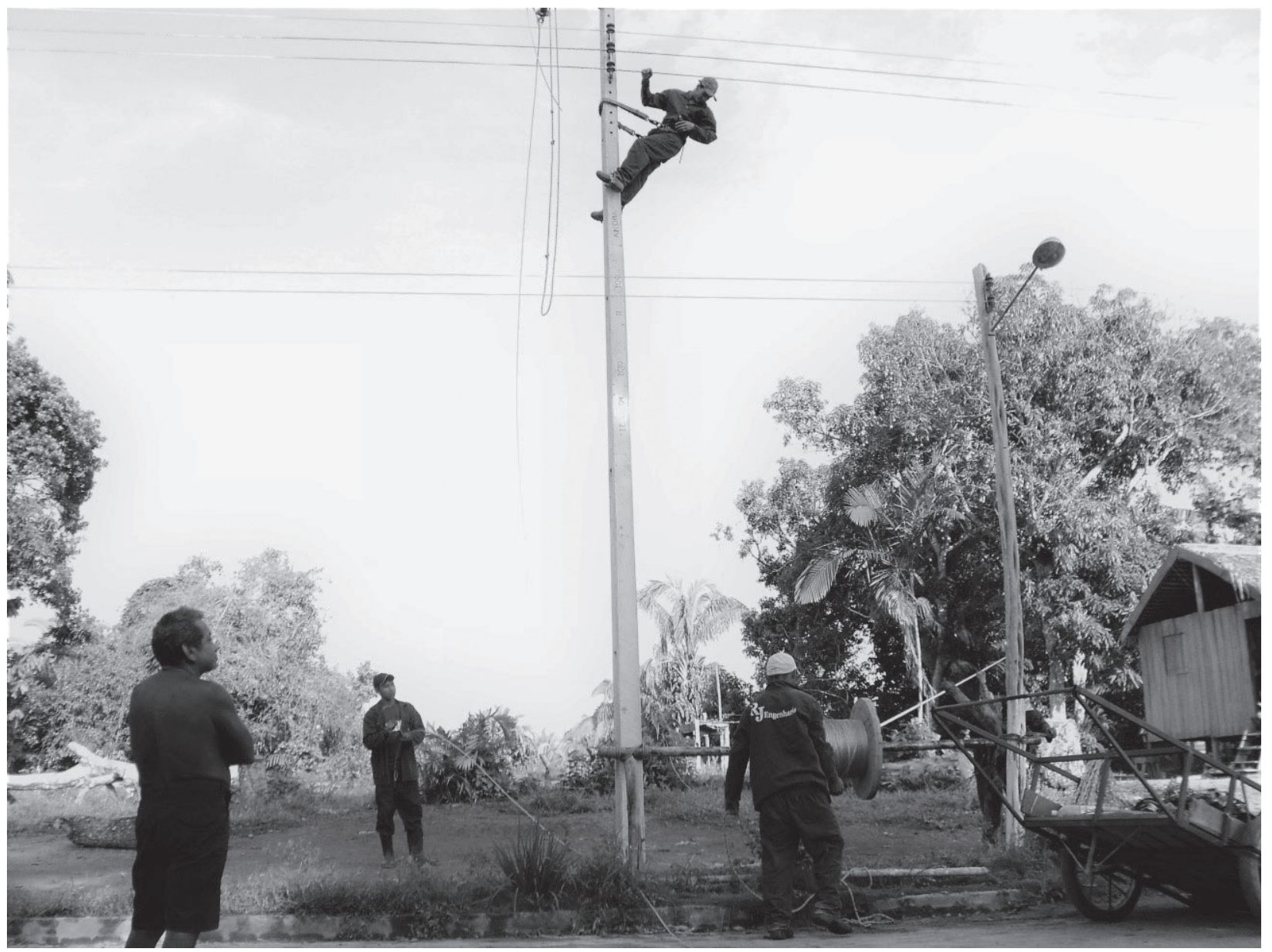

Foto Raquel Scopel.

Segundo me explicou o cacique Manoel, o programa do governo federal Luz Para Todos havia chegado às aldeias da TIKL no segundo semestre de 2010. Com isso, homens Munduruku acabaram se envolvendo no trabalho de construção da nova linha elétrica na tarefa de abrir uma picada com cerca de quatro quilômetros na mata, ligando o rio Madeira ao centro da aldeia Kwatá. Essa picada serviu para instalar os postes de concreto com a fiação elétrica até as casas da aldeia.

Quando retornamos ao campo, em março de 2011, já havia energia elétrica intermitente na aldeia Kwatá. Isso incrementou as atividades da vida noturna na aldeia, como, por exemplo, reunir um grande número de adultos e crianças em volta da televisão para assistir ao jornal, à novela ou a um DVD na casa de algum parente, além de ter facilitado o trânsito das pessoas à noite, fosse para passear ou fazer visita, fosse para frequentar as aulas de educação para jovens e adultos. 
A construção da nova escola também ocupou o tempo de alguns homens Munduruku no ano de 2011. Da mesma forma que a instalação da rede elétrica, a construção da escola também exigiu dos homens Munduruku sua dedicação e força de trabalho ao longo do dia.

A empresa construtora contratou mão de obra na aldeia mediante o pagamento de diárias. O trabalho era pesado e incluía tarefas como carregar madeira do rio até o local onde seria a escola, cavar fossas, além de construir paredes, piso e rebocar. Infelizmente, os trabalhadores não dispunham de itens de segurança adequados para executar o serviço e houve quem sofreu acidente de trabalho, ao cair do telhado.

Os homens se ausentavam de casa com frequência, pois caçar e pescar demandavam tempo. Em certo sentido, o retorno para casa com a caça ou o peixe justificava essa ausência. Mesmo naqueles casos de fracasso nas incursões, por "panemice" ou intempéries, se compreendia sua ausência, afinal nem toda caçada ou pescaria era bem-sucedida. Todavia, aqueles homens cujo trabalho já os havia retirado do convívio da família e que retornavam de mãos vazias, estes compartilhavam certo mal-estar. Pelo menos foi assim que sintetizaram a situação o cacique Manoel e o agente indígena de saúde Ricardo. Manoel referia-se ao trabalho de cacique, que o levava para viagens fora da TIKL, nas quais passava dias longe da família por inúmeras vezes. Todos de sua família compreendiam a importância do trabalho de cacique e o apoiavam, embora Manoel sentisse o peso de chegar a casa de mãos vazias. Da mesma forma, o agente indígena de saúde Ricardo também se queixava de passar os dias trabalhando fora de casa, no Polo-Base Kwatá, e retornar sem alimento. Cada um desses homens era membro de uma família extensa diferente. O primeiro não recebia salário e o outro era assalariado. Todavia, ambos avaliaram o próprio envolvimento em um tipo de trabalho no qual os resultados não contribuíam para prover a alimentação diária da família.

Essas autoavaliações ponderavam sobre a contribuição masculina na nutrição diária da família, tendo por pano de fundo o modo de vida dos Munduruku. Em termos analíticos, sugiro que, ao retornar para casa sem comida, os homens Munduruku não estariam cumprindo com sua contrapartida na dinâmica das relações de gênero voltadas para a manutenção da família. O mesmo aconteceria nos casos em que o uso excessivo de bebidas alcoólicas, cujo excesso havia promovido uma desarticulação na reciprocidade entre o casal. A única vez que vi uma mulher se negar a cozinhar para o marido, afirmando que ele não comeria naquela casa, foi quando ele chegou embriagado de uma viagem à cidade, de mãos vazias e sem calçados. Por outro lado, o trabalho assalariado permitia aos homens e às mulheres abastecerem suas famílias com mercadorias. 


\section{Futebol, missas e rodas de conversa}

A vida cotidiana, é claro, não era apenas trabalho. Ao fim do dia, outras atividades de lazer se destacavam na vida diária, como o futebol e as rodas de conversa. Havia times de futebol masculinos e femininos na aldeia Kwatá. As partidas realizadas pelos homens eram diárias, já os times de mulheres costumavam jogar nos fins de semana. Os Munduruku organizavam campeonatos entre times de aldeias ao longo do ano. Nesses eventos, muito apreciados, reunia-se uma grande torcida.

Figura 21 - Mulheres e crianças assistindo ao jogo de futebol

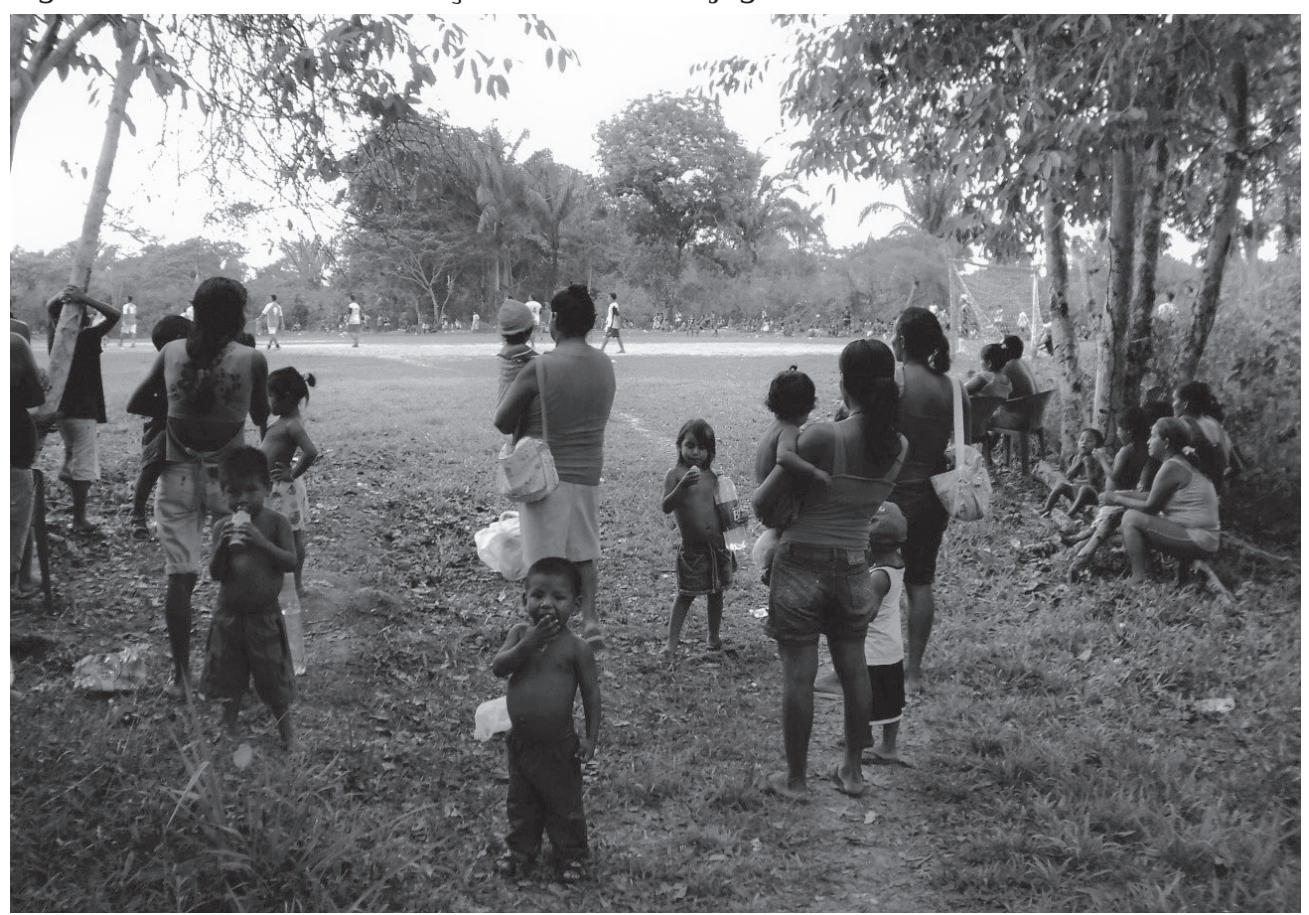

Foto Raquel Scopel.

Ao fim do dia, os Munduruku também se agrupavam em rodas de conversa em frente às suas casas. Em geral, algumas mulheres relacionadas por parentesco iniciavam as rodas de conversa. Eram noras, sogras, cunhadas e irmãs que se reuniam para conversar sobre os eventos do dia, enquanto seus filhos e filhas pequenos brincavam ao redor. Conversava-se sobre feitos diários, dúvidas sobre algum assunto, trocas de receitas sobre remédios caseiros e planos para os dias seguintes. Eram momentos descontraídos, muitas vezes cercados por piadas jocosas e risos. Os homens mais velhos, maridos de algumas dessas mulheres, não tardavam a se juntar a elas e a expor também alguns relatos dos eventos diários. As rodas de 
conversa também eram um momento no qual emergiam narrativas sobre feitos passados do povo munduruku, sobre as conquistas da terra indígena, sobre mitos e histórias que os antigos contavam. Essas rodas de conversa diárias podem ser vistas também como "contextos de performances formais" (Langdon, 1991: 13), propícios à emergência de narrativas que remetem a um tempo mítico ou a um tempo histórico. Essas narrativas eram prerrogativas das pessoas mais velhas e ouvidas com atenção pelos demais adultos presentes. As rodas de conversa foram para mim uma fonte preciosa de aprendizado sobre a vida dos Munduruku.

Nos fins de semana, aos domingos pela manhã, a missa na igreja católica da aldeia Kwatá estava sempre cheia. Todas as vezes que participei, havia pessoas de pé, pois já não restavam mais assentos. O sino da igreja era tocado por volta das 7 horas avisando que logo a missa iria começar. Naqueles dias, todos os homens, mulheres, jovens solteiros(as) e crianças se arrumavam para participar da missa, que era conduzida por professores indígenas e por um dos filhos do cacique Manuel. A dinâmica da celebração da missa envolvia também, e principalmente, os jovens solteiros. Eles(as) participavam de algumas leituras, cantavam, tocavam violão e passavam recados.

Entre 2010 e 2011, havia missionárias não indígenas da Pastoral da Criança que participavam das missas aos domingos, auxiliando nos cantos dos hinos religiosos. As missionárias também organizavam novenas nas casas. Cabe relembrar também outras atividades centrais na atuação daquelas missionárias, como cursos de artesanato (crochê), cadastramento das crianças de 0 a 6 anos e gestantes e a capacitação de indígenas para serem líderes locais da Pastoral da Criança. Embora eu reconheça a importância da atuação das missionárias, cumpre destacar que a organização e a condução das missas eram feitas pelos indígenas.

Durante a missa, homens, mulheres, crianças e jovens sentavam-se separados. Até vi alguns casais sentarem-se juntos, mas esso não era o padrão geral da disposição das pessoas durante a celebração da missa. Na parte da frente, nos primeiros bancos, estavam as crianças, entre 4 e 10 anos, dispostas ao lado direito do altar. No lado esquerdo ficavam os jovens que auxiliavam na execução da missa. Estes, sim, sentavam-se juntos. Nos bancos ao lado direito do altar sentavam-se as mulheres, acompanhadas de seus filhos pequenos e de colo. Ao lado esquerdo ficavam os homens e os meninos com mais de 11 ou 12 anos. Ao fundo, geralmente de pé, do lado esquerdo, ficavam os rapazes solteiros, e do lado direito, algumas moças. Ao fim da missa, muitos permaneciam em frente à igreja conversando, alguns em rodas de homens e mulheres separadamente, outros acompanhados de seus cônjuges.

Entre os poucos casais que se sentaram juntos estavam o cacique e sua esposa, o pajé e sua esposa. Nos acontecimentos públicos, evidenciavam-se com mais força algumas hierarquias da sociedade munduruku. O cacique era sempre o último a dar a palavra. Muito sábio, Manoel sabia expressar sua opinião utili- 
zando-se das falas anteriores, articulando-as e justapondo-as, para conduzir sua argumentação final. Isso deixava a sensação de que em nenhum momento ele agira de forma impositiva ou autoritária. A autoridade do cacique vinha de sua posição, herdada do pai, e de sua habilidade para falar em público, em um tom de voz médio, porém firme e contínuo, capaz de sintetizar as diversas opiniões de forma organizada. E, claro, em consonância com o que acreditava ser o correto e o melhor para o seu povo. O prestígio do cacique se confirmava especialmente nos eventos públicos, pois ele era indicado como uma liderança a quem as pessoas não indígenas deviam se dirigir e ouvir. Assim foi na reunião de saúde local, nas diversas reuniões com profissionais do cargo administrativo ligados ao Distrito Sanitário Especial Indígena Manaus, na negociação da autorização de nossas pesquisas de doutorado, na reunião da Associação Indígena, nas reuniões com o prefeito de Nova Olinda do Norte, entre outros eventos ocorridos na TIKL. Além disso, Manoel era chamado para resolver conflitos que emergiam dentro das aldeias e atuava como mediador entre os envolvidos, os quais acatavam suas orientações. ${ }^{38}$

Manoel era enfático em afirmar que não sabia como proceder quando assumiu o cargo que fora de seu pai. Segundo o cacique, além das orientações dos mais velhos, o tempo e as diversas situações pelas quais passou dentro e fora da TIKL se acumularam como experiências que o ajudaram nas diversas situações em que precisou atuar. Isto é, o engajamento nas atividades relacionadas ao exercício de cacique foi se sedimentando como aprendizado na prática, junto com os conselhos dos mais velhos. 39

\section{Viagens à cidade e festas}

Por fim, gostaria de mencionar os deslocamentos mensalmente realizados por muitos Munduruku até cidades vizinhas. As viagens para Borba eram menos frequentes e, em geral, feitas apenas pelos indígenas assalariados, que trabalhavam como professores ou auxiliares gerais nas escolas da TIKL, para receberem o salário. Iam também a Borba no festejo da comemoração do santo padroeiro da cidade, Santo Antônio, entre o fim de maio e o início de junho. A festa de Santo Antônio de Borba é um dos maiores eventos religiosos do interior do Amazonas e reúne milhares de peregrinos. Os indígenas atravessam a pé longas distâncias no interior da TIKL até alcançarem as margens do rio Madeira, onde pagam por uma passagem no transporte feito por barcos que navegam no trajeto de Nova Olinda do Norte a Borba e, em alguns casos, até cidades do Pará. A viagem de ida e volta até Borba para receber o salário ocupava dois dias, exigindo o pernoite fora de casa e uma despesa extra na contabilidade mensal da família. 
As viagens para Nova Olinda do Norte eram mais frequentes e, a depender da distância da aldeia até a cidade e do tempo de deslocamento, podiam ser feitas em um único dia. Em geral, os indígenas iam até Nova Olinda do Norte principalmente para fazer compras no comércio local da cidade ou por motivos de doença. Neste caso, o deslocamento se justificava tanto pelo atendimento na rede do Sistema Único de Saúde (SUS), mediante encaminhamentos feitos pelos profissionais do polo-base, quanto pela procura dos curadores urbanos. ${ }^{40}$ As viagens para Nova Olinda do Norte, feitas por conta própria, eram de rabeta. Os Munduruku também iam a Nova Olinda do Norte para receber os benefícios do Bolsa Família ou a aposentadoria. Mesmo para os moradores das aldeias mais distantes, o trânsito pela cidade era rotina e, em alguns casos, envolvia a cooperação entre as famílias elementares que dividiam os custos da viagem ou emprestavam sua canoa.

A preparação das aldeias para as festas envolvia as famílias extensas em trabalhos coletivos, as quais cooperavam entre si para limpar a aldeia, organizar as atividades e preparar a alimentação oferecida gratuitamente a todos os participantes. Em geral, os Munduruku costumavam ir até a aldeia que oferecia a festa. Assim, havia um trânsito de pessoas também entre as aldeias. Aliás, nas maiores festas da TIKL, os chamados festivais culturais, comemorados ao longo de uma semana com inúmeros jogos, competições artísticas e exposição de arte e artesanato, também moradores indígenas e não indígenas da cidade de Nova Olinda e de Manaus vinham participar. Eram as festas em comemoração ao Dia do Índio. ${ }^{41}$ Numa delas, aprendi que naquela terra indígena não havia "indígenas", havia Munduruku. Um homem olhou para seu cunhado e, sorrindo, falou em tom jocoso e provocativo:

- E aí, indígena, aonde vai, indígena?

O cunhado, sorrindo, respondeu:

- Eu sou Munduruku.

Em seguida, o primeiro homem confirmou:

- Eles não gostam de ser chamados de indígenas, nós somos Munduruku. Qualquer um que não fosse Munduruku era pariwat, termo da língua munduruku que designa inimigo ou branco.

\section{Tempo e cosmo}

Para apresentar ao leitor a vida cotidiana dos Munduruku, selecionei aquelas atividades em que homens e mulheres passavam a maior parte do tempo envolvidos, como pescar, caçar, roçar, cuidar da casa, lavar roupas e louças, fabricar a farinha, cuidar dos filhos, frequentar a escola, jogar futebol aos fins de semana e participar das rodas de conversa ao final das tardes. Certamente, outras atividades poderiam ter sido apresentadas, caso eu estivesse acompanhando, por exemplo, a 
rotina de trabalho dos agentes indígenas de saúde ou dos pajés ou curadores, dos professores, das lideranças ou dos conselheiros de saúde indígenas. A vida cotidiana tem mais imponderáveis do que a pretensão analítica pode conter. Ademais, ela está diretamente relacionada à conjuntura na qual o ator social, individual ou coletivo, interage. Todavia, a dinâmica das atividades praticadas pelos Munduruku é ritmada por turnos - manhã, tarde e noite - demarcados por alguns horários-chave que predispõem a uma abertura, como uma fenda no tempo, para as relações sociais perigosas. Essa fenda no tempo é importante para manter o distanciamento ideal entre os humanos e os seres subaquáticos, especialmente os botos encantados. Desse modo, os Munduruku devem resguardar os seguintes horários: meio-dia e 6 da tarde. Cumpre esclarecer que, de fato, não estamos lidando com a precisão cronometrada pelo relógio, mas com uma noção temporal expressa pela regularidade dos turnos. Resguardar, nesse caso, tem o sentido amplo, similar ao que encontramos nos dicionários de português, de guardar com cuidado, de agir com cautela e, mais particularmente, de evitar a beira do rio nesses horários. O resguardo também implicava um período de liminaridade. A evitação incluía tomar banho, brincar ou exercer qualquer outra atividade durante essas horas. O motivo era manter distância dos seres encantados, botos, que estão circulando pelo rio naqueles momentos. A razão para o distanciamento é que tais encontros podem redundar em relações que, ao final, resultarão em doenças graves e risco de vida.

A vida diária dos Munduruku exige uma constante vigília para além dos horários citados. Os Munduruku habitam um cosmo em que outros seres convivem, cada qual inicialmente relacionado a um habitat, embora todos configurem parte da cosmografia local. Para os Munduruku, o cosmo é habitado por seres humanos, por seres encantados com capacidade de "engerar" para humanos, com destaque para os botos, por humanos com capacidade de "engerar" para animais (feiticeiros que se transformam em onça) e por seres subterrâneos e subaquáticos, animais e plantas de variadas espécies, algumas das quais também se transformavam em homens e animais. ${ }^{42}$ Os Munduruku habitam as aldeias, navegam os rios e usam suas margens para uma infinidade de atividades, frequentam os centros das matas como passagens para viagens ou mesmo caçadas e abrem suas roças a meio caminho entre a aldeia e o centro da mata. Os gentirana ou kokeriwat (na língua munduruku) são seres de estatura pequena, de pele escura, que habitam o subterrâneo mas saem à superfície terrestre, podendo se relacionar com os Munduruku. Há ainda os espíritos do ar, o espírito mau ou inimigo, a alma daqueles que morreram por ação do inimigo, os afogados, atirados e enforcados.

$\mathrm{Na}$ cosmografia munduruku, conforme dito anteriormente, cada lugar, seja um acidente geográfico (olho d'água, mata, igarapé, igapó etc.), seja o produto da atividade humana (roça e cacimba, por exemplo), é habitat de mães e donos. Mães e donos são os seres responsáveis por tais lugares, são seus 
donos e seus protetores, e por isso é preciso pedir licença para adentrar, pescar, caçar ou plantar no espaço deles. Pedir licença para caçar, passar, banhar-se no rio ou na cacimba, entre outros, justificando a necessidade da aproximação, faz parte do código moral e da etiqueta entre humanos e mães e donos dos lugares, como demonstração de respeito. Os Munduruku compartilham uma cosmografia mantida pelo esforço de gerenciar diariamente um distanciamento ideal entre eles e os demais seres que habitam o cosmo. Essa distância - ou aproximação mediada pela etiqueta social - garante a manutenção da saúde, seja dos atores diretamente envolvidos, seja daqueles que compartilham um mesmo segmento residencial, especialmente das crianças. Assim, as práticas de evitação ou a etiqueta social no relacionamento com os demais seres que habitam o cosmo podem ser entendidas como ação apropriada para criar relação em termos aceitáveis e manter o bem-estar individual e da comunidade. Apenas aos pajés é permitido o trânsito livre entre o mundo dos humanos e o mundo dos encantados. Contudo, eles também mantêm uma série de práticas de autoatenção para se manterem saudáveis e se relacionar com os encantados, com quem atuam nos trabalhos de cura.

Entretanto, não são apenas certas atividades ou os horários e espaços em que tais eventos ocorrem que exigem cautela dos Munduruku, mas também alguns estados relacionados a momentos da vida, que demandam um modo de proceder atento e cauteloso. A menstruação é um caso típico, conforme apresentarei no Capítulo 4. Outro estado em que as pessoas cumprem resguardo é durante o período do pós-parto. O pós-parto também desponta como período marcado por tabus, prescrições e proibições, cujas características mais marcantes são algumas inversões relativas às atividades cotidianas. Durante o trabalho de campo, observei que havia outros momentos em que os Munduruku praticam resguardo, como já apontei: Dia dos Finados, visita ao cemitério, luto, convalescença causada por animais peçonhentos e na menstruação. De todos esses eventos, o resguardo do pós-parto é o mais prolongado, e aquele cujas consequências podem se estender sobre a vida de qualquer outra pessoa próxima, e não apenas àquela que rompe com a regra. Desse modo, a quebra do resguardo do pós-parto tem o potencial de desencadear risco de vida para todos os próximos, especialmente para as crianças, como veremos no Capítulo 7. 


\section{Notas}

30 Um modelo é um esforço analítico incapaz de conter a complexidade e a dinamicidade da vida real; extrai das observações e participações apenas os constructos que contribuem para explorar determinado tema em específico (Menéndez, 2011: 7).

31 Scopel (2013: 206) apresenta detalhes do processo de doença de Ceci ao abordar "as relações entre práticas de autoatenção e demais modelos de atenção à saúde e às enfermidades".

32 Prática preventiva para evitar contato com seres subaquáticos capazes de causar doenças e engravidar as mulheres.

33 A mandioca plantada pelos Munduruku para fabricar farinha é a mandioca brava (Manihot esculenta). Durante a pesquisa de campo, não observei a venda de excedentes de produção de farinha.

34 Embora eu focalize as relações de cooperação como um valor social constitutivo das relações de gênero entre os Munduruku da TIKL, é importante lembrar que houve um debate acerca do antagonismo sexual desde a década de 1970, em que as observações feitas pelo casal Murphy (2004) acerca dos Munduruku apontaram um hiato entre a ideologia expressada em mitos e rituais e as relações cotidianas entre homens e mulheres. O casal sugeriu que a questão da subordinação feminina expressava o ponto de vista dos homens Munduruku, que não seria compatível com o ponto de vista das mulheres. Essa observação contribuiu para o debate acerca do antagonismo sexual entre as populações indígenas amazônicas, no qual se questionou a redução do tema a uma equação de dominação masculina sobre as mulheres, sugerindo que se considerasse a possibilidade de uma visão androcêntrica das pesquisas que se concentravam na descrição do ponto de vista dos homens, em que a ênfase recairia sobre o valor social da guerra, da caça e da atuação na política pública, sem, contudo, ignorar que alguns grupos teriam uma organização social visivelmente antagônica (Belaunde, 2005; Langdon, 1982, 1991; Lasmar, 1999; Murphy G Murphy, 2004; Overing, 1999).

35 Ao desenvolver o tema da produção dos laços sociais entre um grupo indígena Tupi, ao sul da Bahia, Viegas (2003) focalizou a sociabilidade de tornar-se um "ser no mundo" através da relação entre pais e filhos engendrada por meio da repetição de uma performance diariamente encenada. A autora conclui que a sociabilidade é resultado de interações diárias, marcadas pela persistência de cuidados cotidianos - "o poder de cuidar, de atrair e agradar" - que relacionam homens, mulheres e crianças (Viegas, 2003: 33). Sublinha ainda "o enorme significado das relações da vida cotidiana na construção da sociabilidade (...) e enfatiza a natureza revogável e condicional dos laços de parentesco" (Viegas, 2003: 4, tradução minha). A abordagem de Viegas parte de uma perspectiva performática do parentesco e ressalta as dimensões das relações intersubjetivas diariamente produzidas e reproduzidas como sua base fundadora. Desse modo, a análise do parentesco como um fato dado pela consanguinidade ou adquirido pela aliança abre espaço para outra dimensão, menos "essencializada", mais dinâmica, pois focaliza as ações diariamente reencenadas [re-enactment] - por exemplo, de cuidado e alimentação (alimentar e ser alimentado) - como maneiras de formar os laços de parentesco.

36 Alguns autores têm focalizado a importância das árvores na vida social de diferentes povos, sugerindo que o conhecimento prático necessário à vida cotidiana seria derivado das experiências concretas de interação e observação com o mundo que os rodeia (Bloch, 1992; Rival, 
1993). Bloch (1992), por exemplo, observou que o povo Zafimaniry, de Madagascar, tinha um conhecimento científico sobre árvores e madeiras, suas diferentes qualidades e os cuidados necessários ao manejo para fins específicos de acordo com os usos desejados. Os Zafimaniry distinguiam algumas árvores nobres e raras cujo crescimento e maturação resultavam no desenvolvimento de uma propriedade (teza), entendida como aquilo que lhes permite endireitar-se, firmar-se e tornarem-se duras, "comparadas aos ossos dos humanos e animais" (Bloch, 1992: 139). Para os Zafimaniry o processo de maturação dessas árvores seria similar ao processo de maturação dos humanos, isto é, determinadas qualidades e propriedades seriam desenvolvidas ao longo da vida e não dadas de forma inata, quer fosse para os homens, quer fosse para as árvores. Rival (1993), ao descrever o processo de crescimento dos bebês Huaorani, na Amazônia equatoriana, também registrou que esse grupo conceitualizava o desenvolvimento corporal e as habilidades pessoais a partir da percepção da maturação observada na "vida vegetal". Entre os Munduruku também algumas árvores ocupavam um lugar destacado nas práticas de autoatenção à saúde, voltadas para a produção social de pessoas.

37 Roberto Da Matta (1973) fez uma análise estrutural da panema a partir dos dados de Wagley e Galvão coletados na região amazônica e concluiu que se tratava de uma forma de pensar e investigar sobre as causas de determinados eventos. O autor sugeriu que a panema expressava o "rompimento de princípios de distribuição dos alimentos" (Da Matta, 1973: 91) ou o contato e mistura de coisas e pessoas que não deveriam ocorrer. Assim, poderia ser interpretada como "sistema determinístico" capaz de indicar sentimentos e expectativas apropriados e distintos que regulariam as relações sociais entre parentes próximos e distantes.

38 Terence Turner (2003: 11), ao estudar sobre "a natureza da hierarquia nas sociedades indígenas da Amazônia", apontou que o valor social indígena Kayapó estava na produção não de bens materiais, mas de pessoas e relações sociais. Heckenberger, a partir da análise do ritual funerário - Egitse (na língua kuikuru) ou Kuarup (na língua kamaiurá) -, dos rituais de puberdade (masculinos) e das questões envolvidas na chefatura, afirmou que esses momentos caracterizavam uma "profunda expressão da diferença" (Heckenberger, 2003: 32). Segundo o autor, a relação intrínseca entre o domínio de recursos materiais e o de recursos simbólicos é elemento-chave na análise do poder político no Alto Xingu. Mais precisamente, o fato de que as relações de poder político e econômico podem derivar do acúmulo de capital simbólico. O poder simbólico seria distribuído "por meio de estruturas que são intrinsecamente hierárquicas" (Heckenberger, 2003: 7, tradução minha), e estas seriam arranjadas no domínio do parentesco e no status das linhagens. Em síntese, ambos os autores observam a importância do prestígio social como meio de transformar capital simbólico em capital econômico e, por sua vez, como formas de angariar auxílio necessário para produzir, manter ou transformar ad hoc, como sugeriu Terence Turner (2003), os valores sociais que constituem os idiomas privilegiados dessas sociedades do Alto Xingu: a produção de pessoas, os rituais de nominação e os festivais. Ao mesmo tempo destacam a importância dos meios materiais (produção de excedentes e presentes, por exemplo) necessários para produzir pessoas. Não farei uma análise sobre a liderança neste trabalho, mas seria interessante investigar futuramente a relação entre prestígio social, autoridade e acúmulo de capital simbólico entre os Munduruku.

39 O leitor encontrará outros exemplos da relação entre memória e experiência prática como processos de aprendizado em Belaunde (2005), Bloch (1992) e Rival (1997). Sobre a prática do aconselhamento na relação entre os Munduruku e os profissionais da saúde na TIKL, ver Scopel (2013). 
40 Scopel (2013) e Scopel, Dias-Scopel e Wiik (2012) apresentam maiores detalhes sobre os deslocamentos em busca de curadores além das fronteiras da TIKL.

41 Scopel (2013) faz descrição e análise dessa comemoração no VI Festival Cultural realizado na aldeia Kwatá, que contou com participação massiva de não indígenas.

42 Scopel (2013: 156) sugere que a noção de "engerar para" é central para se compreender a perspectiva xamânica do cosmo entre os Munduruku, a qual indicaria a possibilidade de transformação em determinada direção, isto é, não se trataria de uma transformação generalizada nem permanente. Wawyniak (2010) também faz uma análise detalhada da categoria "engerar" entre os ribeirinhos do Baixo Tapajós baseada das ideias do perspectivismo ameríndio de Eduardo Viveiros de Castro. 


\section{As Práticas de Autoatenção à Gestação}

Conversar com mulheres Munduruku com a intenção de obter alguma informação sobre práticas de autoatenção à gestação (Menéndez, 2003) mostrou-se, inicialmente, uma técnica de investigação pouco produtiva. Em geral, elas destacavam o esforço físico demasiado a ser evitado, assim como o deslocamento de objetos pesados. Nas falas, citavam como precaução a ser observada para uma gravidez segura e saudável: limitar-se a não cometer extravagâncias no trabalho cotidiano. De fato, a relação entre mulheres de gerações diferentes era marcada por uma tentativa de controle dos excessos. As mulheres mais velhas eram taxativas em suas advertências às gestantes mais jovens quanto ao esforço físico ou ao trabalho exagerado por longas horas na roça ou à beira do rio. Elas falavam em voz alta com a gestante para que todos ouvissem. Segundo as mulheres mais velhas, não era correto trabalhar em excesso, pois a gestante ou mulher buchuda estava "carregando uma criança". Tudo levava a crer que as práticas de autoatenção à gestação sintetizavam um controle dos exageros no trabalho cotidiano para evitar os riscos de queda e aborto. Contudo, no decorrer do trabalho de campo, engravidei, e minha relação com meus interlocutores mudou. Com isso, um conjunto de práticas de autoatenção à gestação passou a ocupar um lugar central em minhas observações e participação na vida cotidiana dos Munduruku.

Ao início da pesquisa, antes de minha gravidez, eu havia obtido muitos dados sobre as práticas de autoatenção relativas ao pós-parto, em contraste com as poucas informações sobre gestação, pois o pós-parto abrangia um período liminar severamente cumprido como resguardo e era tema recorrente nas conversas dos Munduruku sobre suas inquietações. Por esse motivo, procurei aprender sobre as práticas de autoatenção à gestação mediante a comparação com aquelas realizadas no pós-parto. Nas rodas de conversa nos fins de tarde, quando eu perguntava à Lana, que estava grávida de seis meses, sobre seu dia e sobre sua gestação, as informações eram sempre muito genéricas, do tipo "está tudo bem", "foi um dia normal". Eu insistia em refazer minhas questões a cada dia, porém, aos poucos, procurei torná-las mais específicas e, ao invés de perguntar para Lana o que podia comer ou o que havia comido naquele dia, passei a questionar se ela estava comendo 
apenas "comida escolhida". Dado o fato de que o resguardo de pós-parto inclui uma dieta marcada pela restrição de uma série de espécies animais, vegetais e frutíferas, o que contribui para uma refeição feita apenas com "comida escolhida", eu havia pensado que poderia haver um paralelo com o período da gestação. Seguindo a mesma lógica, também perguntei, em dado momento, se havia algum cuidado especial para a mulher grávida. Apesar de meus esforços, posso dizer que esse tema não rendia conversa. Tanto Lana como outras mulheres comentavam que a gestante podia comer de tudo e não havia com o que se preocupar, apenas era importante cuidar para evitar queda e não fazer nenhuma extravagância.

Minhas observações quanto à rotina de Lana confirmavam suas afirmações de que a rotina da mulher Munduruku não mudava quando grávida. Lana trabalhava como cozinheira no polo-base, cuidava de sua casa, de seus três filhos, lavava roupas e louças na beira do rio, trabalhava na roça e continuou com essas atividades durante toda a gestação. O mesmo observei em Lara, que ao nono mês de gestação ainda executava todas as atividades diárias dos cuidados com a casa e seu entorno e dos cuidados com seus outros cinco filhos. Da mesma forma, outras mulheres Munduruku continuaram exercendo suas atividades diárias até o momento do parto, fosse no interior da casa ou em seu entorno, fosse no trabalho na roça ou na produção da farinha ou, ainda, na escola (no caso de uma professora). Parecia não haver nenhuma restrição quanto às atividades e aos espaços de circulação para as gestantes Munduruku, diferentemente do que acontecia no resguardo do pós-parto.

Todavia, esse cenário mudou bastante quando, grávida de três meses, iniciei a terceira etapa do trabalho de campo. Naquela ocasião, havia ainda outras duas mulheres grávidas na família extensa com que eu morava. Iara, mãe de três crianças, estava grávida de cinco meses e Naná, mãe de duas crianças, de sete meses. A observação participante foi, a partir desse momento, uma técnica intensamente produtiva. O fato de eu estar grávida contribuiu para ampliar e mesmo reverter as informações anteriormente obtidas. As contribuições de Lana e das outras mulheres gestantes, com as quais conversei durante as primeiras duas etapas do trabalho de campo, foram se detalhando à medida que vinham me fazer perguntas, advertências e compartilhar experiências. Uma das mulheres grávidas, Naná, era neta e vizinha de Ceci. A outra, Iara, era filha de criação de Ceci. Iara cuidava da casa de Ceci, cozinhava para ela e, muitas vezes, dormia junto com seus filhos na casa de Ceci. Desse modo, éramos duas gestantes compartilhando o mesmo teto e a mesma comida. E, de modo geral, eu era mais uma gestante a fazer o pré-natal no polo-base da aldeia Kwatá, no rio Canumã, na TIKL. 


\section{A importância da menarca no processo de gestação, parto e pós-parto}

Antes de iniciar as descrições sobre as práticas de autoatenção relativas à gestação, ao parto e ao pós-parto, tratarei da importância simbólica do sangue na cosmografia munduruku, pois, além de figurar como elemento norteador dessas práticas, as mulheres mais velhas Munduruku tinham lembranças da menarca, as quais delineavam algumas justificativas para a continuidade do resguardo da mulher menstruada no momento presente, até mesmo para a manutenção do resguardo de mulher parida. Essas experiências pessoais do resguardo da primeira menstruação constituíam uma memória social compartilhada entre gerações e evocavam a importância de seu cumprimento como uma questão de saúde que ultrapassava aqueles momentos específicos do período menstrual e se estendiam à qualidade da vida futura da mulher Munduruku.

Na aldeia Kwatá, dizia-se para uma menina que teve a menarca que ela "ficou vovó". Muitas mulheres de 30 anos ou mais lembravam o dia em que "ficaram vovó", isto é, em que menstruaram pela primeira vez. Lúcia tinha mais de 40 anos e fez um paralelo com o resguardo do pós-parto ao me contar sobre como foi sua primeira menstruação. Ela ficou reclusa dentro do quarto até o sangramento parar, sem sequer "brechar", ou seja, não podia espiar por entre as frestas da casa. Ao cessar o sangramento, antes de poder sair do quarto, sua mãe e sua avó materna fizeram defumação nela e prepararam banhos com "plantas cheirosas" para ela tomar. Tudo para evitar que o boto sentisse o cheiro de seu sangue e "se agradasse" dela, o que poderia trazer sérias consequências para sua vida. Ficar dentro do quarto, sem espiar nem sair daquele espaço durante todo o período de sangramento e por mais dois a três dias após a cessação da menstruação, era ponto comum nas experiências das mulheres Munduruku mais velhas. Ceci estava com 92 anos durante a última etapa da pesquisa de campo e lembrava ter passado pela reclusão incentivada por sua mãe para não ficar triste. A mãe de Ceci a teria ensinado a cumprir o resguardo com disposição e lhe dito para ficar na "rede, tecendo alguma coisa, faz alguma atividade, na rede, pra ti ser uma mulher esperta". Para os Munduruku esperteza significa disposição, e esperta é uma pessoa bem-disposta, que tem iniciativa. Com base em conversas com homens e mulheres Munduruku, em que expressavam uma avaliação sobre as atitudes de determinadas pessoas, sugiro alguns sinônimos pertinentes para esperta: vivaz, hábil, zelosa, cuidadosa, ágil, diligente. Antônimo de esperta seria "mulher mufina", segundo Ceci. A noção de mulher mofina, que emergiu nas conversas sobre a gestação, está diretamente relacionada com o resguardo da menarca. Mais precisamente, o cumprimento do resguardo da menarca e dos demais períodos menstruais contribuiria para formar o caráter da mulher Munduruku. O ânimo e o estado de espírito da mulher 
no cumprimento do resguardo da menarca concorreriam para definir o caráter da mulher virtuosa e o da mulher "mufina". Assim, cumprir o resguardo da menarca e fazê-lo sem tristeza seriam maneiras de formar o caráter de uma mulher cujo adjetivo seria esperta. O inverso seria deixar de cumprir o resguardo ou fazê-lo com má vontade e incorrer no qualificativo de mulher "mufina". É certo que estou fazendo uma generalização. De fato, esses adjetivos não qualificam o caráter de uma mulher de modo estático, pois os Munduruku admitiram que, ao longo da vida, e especialmente no decorrer do cumprimento dos demais resguardos menstruais, as mulheres poderiam estar a cada momento reforçando ou alterando, mudando, seu modo de encará-lo e de proceder.

Além disso, outros fatores e relações sociais concorreriam com os resguardos na formação do caráter da pessoa Munduruku. Nas palavras de Ceci, "eu nunca fui mulher mufina, desde a minha primeira gravidez sempre trabalhei, tinha disposição para cozinhar, para trabalhar, para ir para a roça. (...) mulher mufina que não tem disposição, que só quer ficar dormindo é que o marido fica com panemice".

Para a "panemice", falta de sorte na caça e na pesca e preguiça, há remédios como, por exemplo, lavar os braços do marido com a água que escorre da massa no tipiti ou banhos com algumas plantas do mato ou pimenta. O curioso é que a "panemice" do homem decorre da falta de disposição da própria mulher. Todavia, há outras formas do homem ficar com "panemice": dar de comer para uma mulher grávida, provavelmente identificada como "mufina", ou ter seus instrumentos de caça e pesca tocados pela gestante. Minha intenção não é discutir a "panemice", mas sublinhar dentre as diversas causas possíveis o descumprimento do resguardo da menarca e da menstruação, bem como a necessidade de a gestante manter-se ativa no trabalho durante a gravidez. Isso e o risco de "engravidar de bicho" ou de sofrer "assombro de bicho" são alguns dos efeitos decorrentes do descumprimento do resguardo, seja da menarca, seja da menstruação. Esses efeitos configuram uma dimensão específica envolvida no cumprimento do resguardo da menstruação, marcadamente orientada por uma ação pragmática imediata e preventiva. Entretanto, Araci sintetiza em uma frase uma ideia que ouvi muito em campo: "mulher tem que se resguardar para ter saúde quando for mais velha". Assim, o cumprimento dos resguardos abarcaria ainda uma dimensão mais ampla, diretamente relacionada com a formação da mulher Munduruku e suas virtudes.

Na experiência das mulheres mais velhas e em seus relatos sobre o resguardo da mulher menstruada, evidenciou-se esse propósito mais amplo, marcadamente orientado por uma noção de prevenção, como veremos no Capítulo 7. Por ora, gostaria de sugerir que, para uma devida compreensão da importância do cumprimento dos resguardos, devemos considerar outra dimensão que os cerca. O cumprimento dos resguardos da menstruação parece estabelecer os meios para se "formar" pessoas mulheres em conformidade com atributos socialmente valori- 
zados entre os Munduruku: esperteza, vitalidade, força, habilidade, zelo, cuidado, agilidade e diligência. As mulheres mais velhas rememoraram ainda que o ritual da menarca tinha como objetivo também evitar que se tornassem "filhentas", andarilhas ou preguiçosas. Essa ação intencional de produção das virtudes valorizadas também se aplica ao resguardo do pós-parto e ao ritual masculino indicado aos rapazes quando da mudança de voz, como vimos anteriormente. A "mulher forte e esperta" constituiu-se mediante o cumprimento dos resguardos. O homem é forte e disposto porque cortou uma árvore grande e dura quando mudou de voz.

Sugiro que o modo como a mulher Munduruku se porta durante o resguardo da menarca implicaria seu modo de encarar as atividades e os afazeres da vida diária de uma mulher adulta e também de se portar e enfrentar outras fases da vida e respectivos resguardos, como a gestação, o parto e o pós-parto. O resguardo da menarca munduruku constituiria, assim, um momento privilegiado, mas não exclusivo, para o aprendizado de certas habilidades e qualidades necessárias ao longo de toda a vida. O resguardo da menarca e da menstruação como um momento para a aquisição de saberes, habilidades e qualidades socialmente valorizados e o seu descumprimento como causa de doenças têm sido observados por outros autores estudiosos das populações indígenas sul-americanas (Belaunde, 2006; Coimbra Jr. G Garnelo, 2004; Conklin, 2001; McCallum, 1999: 168; Overing, 1999; Tempesta, 2004). Em geral, esses estudos demonstraram uma relação intrínseca entre a constituição da pessoa ameríndia e a aquisição de gênero como processos contínuos de obtenção de habilidades, saberes e qualidades ao longo da vida, e não como dados a priori. Por isso, esses momentos liminares, entre os quais os resguardos de menstruação, parto e pós-parto, podem ser entendidos como um esforço intencional na manutenção da saúde e da condição de pessoa, uma vez que seu descumprimento poderia gerar doenças e mesmo a morte. Isso porque o sangue poderia ser um veículo diluidor das fronteiras entre os domínios humanos e os não humanos.

A especificidade dos arranjos culturais e cosmográficos praticados entre os Munduruku estaria exatamente na qualidade do sangue, visto como atrativo aos seres não humanos. Conforme destacamos anteriormente, entre os Munduruku da Terra Indígena Kwatá-Laranjal (TIKL) o cheiro do sangue menstrual tinha essa qualidade de atrair os seres que habitavam o cosmo, principalmente os botos. Segundo os Munduruku, é preciso estar constantemente atento, pois o sangue e seu caráter volátil, de modo semelhante ao que ocorre entre os Siona (Langdon, 1991), tem a capacidade de atrair os seres encantados. Essa atração, ao promover uma diluição das fronteiras entre humanos e não humanos, repercutiria na saúde da mulher indígena e também na saúde de todo aquele que passasse sobre o rastro da mulher menstruada. Desse modo, romper interdições, restrições e prescrições socialmente elaboradas sobre os resguardos, os alimentos, as atividades e as relações sociais era considerado fator a afetar diretamente o estado do corpo, compreendido em suas 
dimensões individual, social e política (Lock G Scheper-Hughes, 1996), podendo resultar em perigo grave de doença para si ou para seus familiares e até mesmo em morte.

Nesse cenário de perigo iminente, as práticas de autoatenção à gestação, ao parto e ao pós-parto emergem como esforços intencionais de preservação da saúde e de prevenção da doença, além de promover a reprodução da ideologia sobre a virtualidade, os riscos e o perigo da relação com os seres que habitam o cosmo juntamente com os Munduruku. Aqui, a saúde da mulher é um eixo central para a manutenção do bem-estar dos demais membros do grupo.

\section{Desejo e admiração: o perigo na produção coletiva de corpos}

Quando souberam que eu estava grávida, muitas mulheres e homens Munduruku vieram compartilhar suas experiências de mães e pais e me dar conselhos, especialmente sobre a alimentação durante a gestação e sobre a criação de filhos, além de explicar algumas sensações que eu ou meu esposo poderíamos ter.

Todo um universo de perigos envolvidos nesse período e um conjunto de práticas de autoatenção foram se descortinando nas experiências e conselhos compartilhados. Em certo sentido, não posso deixar de pensar que essa atitude dos Munduruku era, de alguma forma, uma resposta às perguntas que eu vinha lhes fazendo. Todavia, os saberes relativos à gestação são de conhecimento público e compartilhados entre gerações no interior de uma família extensa, mas só parecem fazer sentido no contexto da experiência vivida. Assim, remontam a uma forma intencional e ativa de criação e manutenção das relações sociais, tendo como eixo central uma preocupação prática com a saúde dos indivíduos e do grupo, e não um conjunto de regras normativas. Ademais, parece que a experiência vivida gerava um contexto propício para o aprendizado de conhecimentos necessários à sobrevivência. ${ }^{43}$ Em certa medida, as práticas de autoatenção à gestação também se inserem nesse modelo pedagógico e de aquisição corporal do conhecimento (McCallum, 1999) a partir da experiência vivida. Podemos sugerir que é o corpo social no qual o corpo individual está inserido que ocupa o centro das atenções dos Munduruku. Nesse sentido, o corpo individual, além de ser uma matriz simbólica na qual o corpo social se inscreve, passa a assumir, analiticamente, a dimensão de um instrumento de conhecimento que pode conformar, formar ou transformar o corpo social (Conklin, 1996; Lock G Scheper-Hughes, 1996; Seeger, Da Matta G Viveiros de Castro, 1979; Turner, 2003).

Ao saber que eu estava grávida, Iara me alertou: caso eu sentisse "desejo", eu deveria procurar saciá-lo. "Mas desejo de quê?", perguntei. "Desejo por comida", 
respondeu-me. Conforme explicou Iara, eu não devia sentir vergonha de pedir para comer uma porção da fruta ou o que quer que fosse, caso eu desejasse; deveria saciar meu desejo dizendo apenas "Oh, fulano, me dá um pouco...".

Ceci, ouvindo nossa conversa matinal, ratificou a recomendação de sua filha dizendo-me que eu não precisava sentir vergonha de pedir um pouco da comida de outra pessoa. Jô, genro de Ceci, fez-me a mesma recomendação ao saber que eu estava grávida e alertou sobre a seriedade de não satisfazer um desejo, o que poderia resultar na perda do bebê, isto é, em aborto.

Outro fato interessante nesse caso é que passei a ser utilizada como motivo para toda a família obter certos tipos de comida, especialmente frutas, de vizinhos e amigos. Uma vez pediram a um casal que plantava banana para trazer algumas para "Raquel, que está com desejo". O casal trouxe dúzias de bananas que foram compartilhadas por todos da casa. Outro feito foi uma visita de uma mulher que morava um pouco mais distante da parte central da aldeia. Pedi a Iara que me levasse até a casa de Betina para conversar com ela. Iara prontificou-se e comentou que Betina, a quem chamava de comadre, tinha muito tucumã no terreno em volta da casa. Todos sabiam que eu gostava muito de tucumã. Enquanto eu conversava com Betina, Iara, seus filhos e algumas sobrinhas foram colher tucumã para a "Raquel, que estava com desejo". De fato, todos os moradores da casa de Ceci se beneficiaram com a farta quantia de tucumã que ganhei e levei para casa.

Mais tarde, notei que eu devia ter muito cuidado ao expressar gosto por uma fruta, peixe ou carne de caça, pois poderia gerar situações desconfortáveis, visto que os Munduruku se esforçariam por me trazer ao menos uma porção do alimento mencionado. Dado o fato de eu estar grávida, nenhum comentário sobre comida era interpretado como conversa despretensiosa sobre gostos, trocas de receitas ou mesmo sobre o que haveria para comer naquele dia. Lembro-me da vez em que um caçador da aldeia Niterói passou duas noites na mata do outro lado do rio porque eu comentara que nunca havia comido carne de anta. ${ }^{44}$ Certamente, ele não estava caçando apenas para mim. Todavia, tenho dúvidas se meu comentário não forneceu um motivo a mais para ele voltar a caçar na noite seguinte. No terceiro dia, ele me procurou para comentar que não tivera sucesso na caçada, apesar de seu esforço, e isso sem que eu tivesse sequer ter perguntado algo. Aliás, na aldeia Niterói eu sempre voltei para a casa onde estávamos dormindo com muita comida. As pessoas perguntavam se eu gostava de mamão, por exemplo, e me davam para levar para casa. Ganhei um pedaço de uma ave (nambu) e de uma paca, pois nas duas ocasiões as mulheres estavam limpando a caça para preparar o almoço durante nossa conversa. A ave me foi dada porque eu nunca comera, mas a paca porque eu já havia comido e respondera à pergunta se havia gostado. Enfim, embora eu tenha respondido que não sentia desejo toda vez que me perguntavam diretamente "sente desejo?", qualquer comentário sobre comida ou minha presença e observação 
durante a preparação de um alimento, isto é, o fato de eu ficar olhando como se depena uma ave ou como se escalda uma paca, enquanto conversava, por exemplo, parecia ser o suficiente para os Munduruku me oferecerem uma porção. Em parte, isso poderia ser interpretado como uma característica da hospitalidade munduruku, cujo costume era presentear os visitantes com alimentos. Porém, isso contrasta com minhas experiências anteriores em visita às casas, quando nem sempre eu recebia alimentos como presente, ao passo que isso se tornou muito significativo durante minha gravidez.

Note-se que o desejo é uma espécie de apetite, uma vontade de comer estimulada pela visão de um objeto, alimento, que outra pessoa produz (plantação de bananas, tucumã, caça etc.) ou está preparando (limpando a caça) ou consumindo. Observei também que havia uma intensa rede de trocas de alimentos. A circulação de alimentos conduzida no cotidiano pelas mulheres Munduruku, muitas vezes feita por crianças, permite deduzir os contornos da rede de relações que limitam a expressão e a satisfação do desejo. Na vida diária é comum a troca de comida, especialmente na refeição principal, o almoço. Essa troca de comidas inclui, exclusivamente, itens de carne (caça, pesca ou frango comprado). A farinha de mandioca, item central ao lado da carne na composição de uma refeição completa, não costuma ser trocada, e não dispor dela não é algo bem visto. A troca de alimentos é feita no interior da família extensa, principalmente entre aqueles parentes cujas habitações são contíguas, isto é, que compartilham um mesmo segmento residencial, mas pode incluir também trocas feitas entre outros vizinhos, comadres e amigos. Enfim, a troca é feita no interior da rede de apoio mútuo, a qual se (re)cria e se mantém principalmente através do envolvimento nas atividades de produção, circulação e consumo dos alimentos e também da participação nas práticas de autoatenção em eventos de doença grave de algum parente (Scopel, Dias-Scopel G Wiik, 2012; Scopel, 2013).

Nunca perguntei por que eu poderia perder o bebê caso não saciasse meu desejo. Alimentar-se bem é, certamente, uma forma de se manter saudável ou de recuperar a saúde, pois tanto a escassez de comida pode gerar enfermidades como uma dieta mal balanceada pode agravar doenças, também do ponto de vista dos Munduruku. Scopel (2013) analisa entre os Munduruku da aldeia Kwatá casos de doenças ("derrame", "doido", "assombro de bicho") em que a alimentação e o modo de preparo dos mantimentos são de grande importância, ao lado de outras técnicas (banhos, massagens, benzimentos etc.), nas práticas de autoatenção para reabilitar a saúde. Entre as populações indígenas amazônicas, a equação entre alimentação e saúde compõe um vasto saber sobre dietas específicas para determinadas situações nas quais a pessoa se encontra em estados liminares como doenças, ritos de iniciação, luto, menstruação, gravidez ou pós-parto, entre outros (Da Matta, 1976; Maués G Motta-Maués, 1978; Seeger, Da Matta G Viveiros de Castro, 1979; Seeger, 1980; Tempesta, 2004). Desse modo, o esforço na tentativa 
de saciar o desejo constitui um conjunto de práticas diretamente relacionadas à saúde do feto e uma forma de zelar por sua vida, visto que ignorar o desejo pode resultar na morte do bebê, em aborto.

O desejo não saciado pode ter outras consequências. Para alguns, provocaria na criança um comportamento desvalorizado entre eles, a saber, permanecer de boca aberta. A imagem de uma criança de boca aberta é associada à falta de concentração e disposição e à letargia; em síntese, remete ao estado contrário daquele da criança alerta e cuidadosa, o que pode afetar sua integridade física e social. Estar alerta enquanto executa qualquer atividade rotineira, proceder de forma cuidadosa, diligente e zelosa demonstram uma atitude de atenção e de disposição muito valorizada na vida adulta munduruku e necessária ao desenvolvimento pleno de certas habilidades relativas ao trabalho cotidiano (caça, pesca, roça e cuidados com a casa e seu entorno) e à sobrevivência no ambiente onde a vida diária transcorre. Com exceção do horário da aula, as crianças estão sempre próximas aos adultos e, a depender da idade, se envolvem nas atividades rotineiras, especialmente de cuidados com a casa, a roça e a produção da farinha. Nos caminhos que levam à roça e nas trilhas no interior da aldeia é preciso estar atento à presença de cobras e onças que podem tirar a vida de um Munduruku ou deixá-lo com sérias sequelas, mas também é bom estar atento aos animais de caça que circundam as roças, como veados, pacas e cutias. É preciso também estar atento aos perigos do contato com outros seres que habitam o cosmo munduruku, como os seres do mundo subaquático, subterrâneo, espíritos do ar, espírito maligno, entre outros, os quais podem assaltar a saúde e a vida de crianças, jovens, velhos, homens e mulheres Munduruku (Scopel, Dias-Scopel G Wiik, 2012). ${ }^{45}$

As duas consequências - seja o aborto, seja a boca aberta - são indesejáveis e incidem sobre o corpo da criança. Conforme a professora munduruku Rosinete Brasil Cardoso (2011: 1) apresentou em trabalho para o curso de Licenciatura Indígena, "certas admirações" da mãe durante a gestação podem afetar a "formação física da criança". Desejo e "admiração" assumem, nesse contexto, um lastro simbólico semelhante, pois ambos são sentimentos e comportamentos que instauram uma relação social entre o admirador e aquele - ou aquilo - que é admirado, entre aquele que deseja e o que sacia o desejo, isto é, colocam pessoas em relações diferentes com o objeto de desejo ou de admiração que, ao final, colaboram para a "formação física da criança", isto é, em uma etapa da produção de seus corpos. ${ }^{46}$

Os Munduruku consideram plausível que nem toda mulher sinta desejo ou "certas admirações", como também admitem que o objeto de desejo, o tipo de alimento, varia conforme a pessoa. O que não é admitido é ignorar tais sensações e deixar de se esforçar para saciar tais vontades, essas "certas admirações". Poderíamos ponderar sobre o que constitui comida para os Munduruku, isto é, o que é apreciado como alimento, tal como o fez Gow (1989) para os nativos do Baixo 
Urubamba, no Peru, e analisar as relações de gênero na economia de subsistência e seus desdobramentos na organização social da vida cotidiana. Lembro-me do dia em que cheguei à casa de minhas anfitriãs e elas falavam que não tinham feito almoço porque não havia comida. Apenas Ceci, pessoa idosa, havia comido um pedaço de frango dado por sua nora. Apesar de haver na dispensa da cozinha feijão, macarrão, arroz, molho de tomate, abóbora, repolho, alho, cebola e outros temperos que eu havia comprado na cidade e deixado aos cuidados de Iara, afirmaram que não havia nada para comer. Isto é, não havia carne, fosse de peixe, caça ou frango, apesar de haver farinha de mandioca. Sugiro que uma refeição completa para os Munduruku inclui proteína animal (peixe, caça ou frango) e farinha de mandioca. A falta de qualquer um desses itens equivale a falta de comida. A classificação dos alimentos desempenha um papel central na gestação quando o foco é a dieta da mulher gestante. Ao selecionar o tipo de alimento ingerido, a mulher gestante está intencionalmente tentando controlar a produção do corpo e do temperamento/ caráter de seu futuro filho. Os alimentos, assim, deixam de ter apenas uma função nutricional para assumir uma dimensão simbólica e prática.

Cabe sublinhar aqui que a satisfação do desejo inaugura uma prática de autoatenção à gestação, que essa prática incide sobre a formação do corpo do feto a partir da circulação e do consumo de alimentos que, por sua vez, (re)criam e mantêm ativas as redes de apoio mútuo e as relações de cuidado entre parentes. Assim, a satisfação do desejo constitui uma das práticas de autoatenção à gestação, a qual motiva, instaura e mantém as pessoas em relações afetivas orientadas por práticas de cuidado. A satisfação do desejo promove ações e relações sociais que, ao fim, afetam o corpo do feto e podem se estender ao corpo da criança após o nascimento.

Se a satisfação do desejo por comida contribui para a formação do corpo da criança, esse processo de produção também está sujeito a falhas, pois nem sempre se obtém sucesso na satisfação do desejo. E o desejo não saciado pode afetar a integridade física e social da criança, que pode ficar com a boca aberta e também ter afetado o desenvolvimento de determinadas habilidades necessárias à condução plena da sociabilidade e à produção da vida na sociedade munduruku.

O exemplo das práticas relacionadas ao desejo demonstra que é a ideia de processo social que está em destaque no desenvolvimento do corpo do feto, e não a de um processo exclusivamente fisiológico e autônomo. Não é um processo de desenvolvimento marcado exclusivamente por eventos morfogênicos, explicáveis pela biomedicina, que está em foco, mas uma compreensão do corpo peculiar aos Munduruku que não separa, a priori, o social do biológico. Do ponto de vista da análise antropológica, o corpo do feto se desenvolve pela relação social que mãe, pai e parentes estabelecem para satisfazer o desejo por determinada comida. A observação do movimento para satisfazer o desejo torna possível especular sobre quais relações sociais são privilegiadas. Nota-se que não são as 
relações de gênero que têm destaque nesse momento, mas as relações entre os membros da família elementar e os membros da família extensa.

Vergonha/respeito constituem atitudes e sentimentos que deveriam caracterizar as relações sociais entre determinadas pessoas. Há uma gradação nas relações de vergonha/respeito. Nas relações maritais, entre casais maduros, é a jocosidade que dá o tom da interação. Pude escutar uma mulher Munduruku falando, em tom de brincadeira, ao seu marido que havia acabado de aportar a canoa na beira do rio, que ele "não vai entrar em casa se não trouxer comida". Ouvi também uma mulher Munduruku dizendo ao seu marido, filhos e sobrinhos que "para comer tem que trabalhar".

Entre sogras e noras, genros e sogros, cunhados de sexo oposto e entre mulheres e homens casáveis, a vergonha/respeito e, muitas vezes, a evitação dão o tom da relação. Esse ideal de etiqueta social, seja da vergonha/respeito, seja da jocosidade, tem seus matizes, variando conforme a maturidade das relações sedimentadas ao longo do tempo. Esse é o caso das relações entre sogras e noras, genros e sogros e cunhados de sexo oposto, cujo tempo de convívio pode amenizar a seriedade da vergonha/respeito. O desejo parece ser um meio legítimo de suspender as relações de vergonha/respeito a qualquer tempo; lembremos que fui advertida da seguinte maneira: "Dona Raquel, você não tenha vergonha de pedir".

Contudo, ainda que nenhum Munduruku cogitasse negar comida a uma mulher grávida, isso não significa que a mulher grávida não sentiria vergonha em pedir comida, o que a colocaria na situação de ter um desejo insaciado e, consequentemente, implicaria perigos tanto para o desenvolvimento do feto quanto para a rede de relações sociais em que a mãe está inserida. ${ }^{47}$

Em termos analíticos, o desejo por comida pode ser entendido como uma experiência intersubjetiva que marca o período da gestação legitimado socialmente. Nas experiências de desejo, as pessoas envolvidas colocam em ação uma série de práticas de autoatenção por meio de esforços coletivos e individuais de cuidado e apoio mútuo que, ao fim, afetam o corpo da criança.

\section{Abalo de criança}

Na gestação também se pode sentir "abalo de criança". Tal qual o desejo, o "abalo de criança" pode ser entendido como uma experiência intersubjetiva que marca o período da gestação e se caracteriza por um conjunto de sensações culturalmente elaborado. Ambas as experiências têm em comum o fato de terem seu sentido negociado entre o casal e os parentes mais próximos, isto é, a confirmação de uma ou de outra é construída e legitimada coletivamente. Da mesma forma que nas experiências de desejo, nas experiências de "abalo de criança" as pessoas 
envolvidas também colocam em ação uma série de práticas de autoatenção por meio de esforços coletivos e individuais de cuidado e apoio mútuo. Todavia, chega a ser redundante afirmar que os sentidos negociados e as sensações experimentadas são o que confere especificidade a uma ou a outra experiência. É com base nas práticas de autoatenção, observadas e descritas, que reflito a seguir sobre o "abalo de criança".

Certa vez, descobrimos que não apenas eu poderia sentir desejo, meu esposo também ficaria sensível a alguns sinais da gestação. Quando respondi que eu não sentia desejo ou enjoo, um homem Munduruku perguntou ao meu esposo se ele sentia desejo, enjoo ou cansaço. Ele nos explicou que o pai pode sentir o "abalo de criança". Meu interesse por essa sensação despertou quando nossos anfitriões e amigos mais próximos, com os quais compartilhávamos diariamente momentos nas rodas de conversa ao fim do dia, concluíram que meu esposo Daniel - o pai estava sofrendo "abalo de criança".

Entre risos e conversas, Araci, que teve 13 filhos e sabe "pegar barriga", "partejar" e "puxar a mãe do corpo", comentou que Daniel demonstrava sinais de cansaço e estava magro. Era início da tarde, havíamos almoçado poucas horas antes e estávamos sentados na varanda da casa de Ceci fazendo a digestão, esperando o sol baixar um pouco. Ceci complementou a avaliação de Araci e afirmou que Daniel estava mais falante na primeira vez que ficamos na casa dela, durante a primeira etapa de trabalho de campo, e agora mais calado e sonolento. Coincidentemente, naquele momento Daniel estava realmente com sono e acabara de bocejar; foi quando Jô e Itamar, cunhado e filho de Ceci, respectivamente, avaliaram que a "criança estava puxando mais pelo lado do Daniel", isto é, ele estava sofrendo "abalo de criança". Daquele dia em diante, o pai Daniel passou a ser o foco de atenção dos Munduruku e de suas perguntas sobre desejo, enjoo, cansaço, entre outras questões, como perda de peso, por exemplo, e eu passei de personagem principal a coadjuvante, ainda no terceiro mês da gestação. ${ }^{48}$

$\mathrm{Na}$ aldeia, as atenções dos Munduruku se voltaram para o meu esposo até o quinto mês de gestação, quando, então, o motivo para o abalo de criança foi revelado. Jô era conselheiro local de saúde da aldeia Kwatá e tornou-se um informante-chave para temas sobre a saúde indígena e sobre "abalo de criança", pois ele mesmo sentira isso durante a gravidez de sua esposa. Certa noite, Jô e sua esposa Ivana vieram nos fazer uma visita e perguntaram se já sabíamos o sexo do bebê. Daniel contou que era menino e Jô disse: "É assim mesmo, quando é filho homem puxa mais pro pai".

Em seguida, relatou sua experiência e lembrou que também havia sofrido "abalo de criança" e ficado tão magro que quase morreu. Enquanto sua esposa engordava, ele emagrecia e sentia muito sono. Durante uma pescaria, Jô caíra no sono ali mesmo na canoa, no meio do igarapé. Naquele dia, voltou para casa sem peixes. A situação dele passou a melhorar com o desenvolvimento da "criança" 
(ainda um feto), isto é, quando a criança já estava "madura", o que ocorreu por volta do quinto mês. Aliás, o perigo de morte causada pelo desejo não saciado, conforme Jô lembrou naquela mesma noite, varia de mulher para mulher e vai depender de a "criança" já estar "madura" ou não, pois se estiver "madura", isto é, se tiver chegado ao quinto mês da gestação, estará mais segura.

Os Munduruku entendem a gestação e o desenvolvimento do corpo da criança de modo processual, no qual intervém uma série de elementos. Utilizavam a metáfora do amadurecimento - "criança madura" - que, de certa forma, explicitava a ideia de sazonalidade e de processo em analogia com as frutas. Nas práticas de autoatenção para satisfazer o desejo, sublinhamos a interveniência das relações afetivas no interior da família extensa e, principalmente, da família elementar. Agora proponho nos determos na relação social entre pai e feto a partir das ações referidas ao "abalo de criança".

De certo modo, a identificação do "abalo de criança" é uma forma de pensar sobre o sexo do bebê com base na relação social entre o feto e seu genitor. Igualmente, nesse assunto, não há consenso entre os Munduruku. Para alguns, suas experiências demonstram que o filho homem "puxa" mais pelo pai, por isso o pai sentiria o "abalo de criança". Para outros homens Munduruku, havia sido sua filha mulher que os abatera com o "abalo de criança". Apesar de a experiência vivida contribuir com o debate sobre o sexo do bebê e sobre a quem ele mais "puxaria" durante a gestação, o sentido do "abalo de criança" parece referir-se a duas ações complementares: de um lado, à construção social da paternidade e, de outro lado, à construção social do corpo do feto.

No caso específico do "abalo de criança", é a relação entre feto e pai que está em foco. Foram os homens Munduruku que compartilharam suas experiências de "abalo de criança", fosse o filho homem ou a filha mulher que tivesse "puxado mais pelo pai". Não vi nem ouvi mulher alguma sofrer "abalo de criança". Ao contrário, vi mulheres gestantes trabalhando normalmente, engordando e, em alguns casos, sendo advertidas para minimizar, desacelerar o ritmo e o peso das atividades. Em contrapartida, os homens Munduruku se mostraram mais vulneráveis ao "abalo de criança" e eram incitados a reagir, a "não se entregar". Lembremos que, para a família extensa em que Daniel e eu estávamos inseridos, ele estava com "abalo de criança".

Os sinais mais comuns de "abalo de criança" são magreza, fraqueza, abatimento, prostração, enjoo e desejo. O conjunto desses sinais afeta diretamente a condição de saúde do pai, podendo levá-lo a permanecer prostrado na rede por longo período, além de apresentar uma perda acentuada de peso. Embora tais sinais possam indicar que a pessoa está doente, o "abalo de criança" não chega a ser entendido como doença. Os homens Munduruku podem fazer uso de remédios caseiros para amenizar o enjoo, como chá tomado ao longo do dia, ou para se fortalecer, com a 
ingestão de uma bebida fortificante e estimulante tomada pela manhã e seguida do banho no rio. 49 Ainda assim, é preciso operar uma mudança de comportamento para reverter o estado geral do "abalo". A "cura" vem com uma mudança de atitude, com o esforço do pai para driblar a fraqueza, o abatimento e a prostração. O pai é exortado a "não se entregar" para a criança. Ou seja, ele é incitado, encorajado e advertido pelos parentes próximos, especialmente por sua mulher, para reagir e trabalhar, isto é, para caçar, pescar e "não se entregar".

O esforço para "não se entregar" é central nesses casos. Enquanto o pai sente "abalo de criança", os Munduruku entendem que ele está contribuindo com o desenvolvimento do corpo do feto, e "não se entregar" é uma maneira produtiva de continuar a contribuir. O pai que sofre "abalo de criança" deve esforçar-se para não se entregar, pois é seu filho que lhe "puxa" a força, deixando-o fraco, "puxa" sua gordura, deixando-o magro, "puxa" sua vitalidade e seu ânimo, deixando-o abatido e sem vontade. Embora o pai possa alcançar estágios críticos de saúde, como magreza excessiva, nenhum caso de morte por "abalo de criança" foi relatado. Aliás, não é sobre morte que se está falando, mas sobre nascimento. Nesse processo de nascimento e desenvolvimento do corpo do feto, é possível pensar que a agência, 50 em síntese, a capacidade criativa de ação e intervenção nas relações sociais, é negociada na relação entre pai e feto. Ao mesmo tempo que o feto "puxa" do pai aquilo que irá contribuir para o desenvolvimento de seu próprio corpo, o pai reage para se manter forte e ativo, especialmente para continuar executando suas atividades cotidianas de subsistência, de pesca e caça. Do ponto de vista Munduruku, tudo se passa como se o pai estivesse a cooperar com o desenvolvimento do corpo do feto até que ele esteja "maduro". O pai emagrece e a mãe engorda porque seu filho está crescendo, está engordando.

\section{A agência do feto}

As práticas relativas ao "abalo de criança" permitem inferir que a contribuição do pai no desenvolvimento do corpo do feto continua após a sua participação na formação inicial do novo ser. Todavia, não se trata de salientar a exclusividade do pai e de suas ações na formação das "crianças". Para os Munduruku do Canumã, homem e mulher contribuem igualmente para a formação de um novo ser. O homem contribui com o sêmen e a mulher com o sangue menstrual. Ao falarem sobre como os bebês são gerados, eles destacam uma relação de complementaridade entre o sangue menstrual e o sêmen. Assim, uma das formas de contracepção é evitar relações sexuais nos dois ou três primeiros dias que se seguem à menstruação, quando ainda é possível haver algum vestígio de sangue menstrual. As mulheres Munduruku conhecem uma série de remédios caseiros para diminuir o fluxo mens- 
trual e o tempo de sangramento, bem como para aumentar os intervalos entre uma gravidez e outra e para evitar a concepção.

Minha intenção não é apresentar uma teoria nativa sobre concepção e dela derivar consequências sociais. Isso porque não considero pertinente derivar das experiências de "abalo de criança" uma teoria nativa sobre concepção na qual se especificaria a centralidade do pai na formação do feto ou no desenvolvimento de seu corpo, como acontece em outras sociedades indígenas. ${ }^{51} \mathrm{O}$ ponto que merece destaque é a compreensão de que a formação de crianças e o desenvolvimento de seus corpos não se limitam somente ao contato fisiológico direto. Não basta haver relação sexual e a união entre sêmen e sangue menstrual. É preciso que pai e mãe se devotem ao bem-estar do feto. As experiências de "abalo de criança" e de desejo, precisamente as práticas de autoatenção que elas instauram, permitem salientar a dimensão processual da construção social do corpo do feto no interior das relações afetivas inerentes ao grupo primário, como as que se observam no grupo familiar. Essas relações afetivas são marcadas por esforços coletivos e individuais de cuidado e apoio mútuo durante o período da gestação, no qual pai e mãe formam uma unidade dedicada ao bem-estar do feto.

Todavia, há outras maneiras de encarar a gravidez e o desenvolvimento do corpo do feto entre os Munduruku do Canumã. Além do contato fisiológico direto, da união de substâncias masculinas (sêmen) e femininas (sangue menstrual) e das práticas de autoatenção dos pais que, ao final, interferem diretamente na formação do corpo do feto (instauradas pelo desejo e pelo "abalo de criança"), há também a atuação de um ser sobrenatural, o Karusakaibu. Murphy e Murphy (2004: 188) também encontraram essa explicação nas teorias de concepção para os Munduruku do Alto Tapajós que, além de reconhecerem o sêmen como a matéria-prima formadora do feto, ainda citavam a atuação do "herói cultural Karusakaibu". Karusakaibu é citado nos mitos como criador dos Munduruku, dos animais de caça e dos artefatos culturais. Desde Murphy (1958) sabemos que Karusakaibu foi identificado pelos missionários católicos com Deus ou Jesus, reinterpretação reconhecida e aceita pelos Munduruku. Nos dias de hoje, os Munduruku do Canumã falam de Karusakaibu e podem, muitas vezes, traduzir o termo por Deus. Conforme Ceci me explicou, é Karusakaibu quem molda a criança no formato que ela terá, isto é, dá forma ao corpo humano com todos os seus membros e órgãos internos e externos. Murphy e Murphy (2004: 188) encontraram exatamente a mesma correspondência acerca do papel de Karusakaibu na formação das crianças durante a gestação, mas salientaram que não se tratava de uma versão unânime.

A preocupação com o "abalo de criança" no período da gestação pode ser uma prática chave para compreendermos a capacidade de ação do feto para além da vida intrauterina, cuja agência intervém na vida dos genitores e se reflete nas relações conjugais. Em síntese, permite sublinhar que o feto em formação apre- 
senta a capacidade de ação criativa de estabelecer e manter as relações sociais e nelas intervir. Essa capacidade de ação se estende a outras áreas da vida social de seus pais, em específico a economia de subsistência, podendo afetar as relações no interior da família elementar. Desse modo, é possível supor um entrelaçamento entre o "abalo de criança" e a cosmologia.

Em termos cosmológicos, a capacidade de ação, sentimento e reflexão não é exclusividade dos humanos, mas existe em todos os seres que habitam o cosmo munduruku. É nesse sentido que podemos compreender a capacidade de ação do feto, até mesmo para atrapalhar a caçada do pai e os afazeres diários da mãe. É preciso que o pai dispare uma flecha (pode ser em miniatura) em direção à mata para evitar que a criança vá à frente do pai e espante sua caça e para afastar a preguiça. Em síntese, o pai deve se precaver da panema causada pela capacidade de agência do feto. Do mesmo modo, a mãe também precisa construir um paneiro (cesta) e deixá-lo pela mata para não ficar preguiçosa durante a gestação, um mal que pode acompanhá-la após o parto. Nesse sentido, a capacidade de ação do feto é direcionada aos genitores, que acabam por constituir as relações de parentesco, embasadas, nesse momento, numa relação ambígua, pois, na medida em que o pai, ao sofrer o "abalo de criança", e a mãe, ao satisfazer o desejo, cooperam para o desenvolvimento do corpo do feto, este também pode intervir na economia de subsistência da família. ${ }^{52}$

Em termos sociológicos, as práticas relacionadas ao "abalo de criança", além de sublinharem a dimensão processual da formação do corpo do feto, expõem também a dimensão relacional/social envolvida nessa formação. É a mãe, é o pai que contribuíram ativamente para a formação e o desenvolvimento do corpo do feto durante a gestação. Mais do que o sangue da mãe e o esperma do pai para dar início à vida, as ações de autoatenção dos genitores Munduruku têm impacto sobre a formação e desenvolvimento do corpo e do caráter da criança.

De certo modo, trata-se de um corpo formado no interior de uma rede de parentesco, isto é, um corpo aparentado (relatedness). Isso poderia sugerir a dimensão processual e social também das relações afetivas mãe-pai-criança, na qual a criança, desde cedo, é inserida em um circuito de interdependência mútua. Não é apenas o corpo do feto ou o sentimento de maternidade e de paternidade que se está construindo, mas uma relação de pertencimento e dependência marcada pela capacidade de ação da criança ainda no ventre da mãe, pela doação de forças vitais dos pais e pela interação entre todos (mãe-pai-criança). Desde já, adianto que isso apenas se inicia na gestação, pois se estende, com mais intensidade, durante o período do resguardo do pós-parto. 53 


\section{"Filho de bicho não mexe": distinções entre gravidez de gente e gravidez de bicho - misturas indesejáveis}

Houve outra pergunta que me foi feita muitas vezes por diferentes mulheres Munduruku ao saberem que eu estava grávida. Diferentemente das outras perguntas, essa se enunciava em um tom mais sério, expondo mesmo certa apreensão. A pergunta era: "Já mexe?". Ao perguntarem se eu sentia mexer, as mulheres Munduruku estavam operando uma série de reconhecimentos sobre a fecundação, a gestação e o feto e, ao mesmo tempo, indicando-me uma prática específica de autoatenção à saúde da mulher e do bebê nesse período da gestação: uma técnica de massagem denominada "pegar barriga". Em certa medida, a existência dos movimentos fetais indicava uma gravidez saudável. Essa avaliação era feita a partir de uma imagem cultural sobre o feto, seu corpo, seus movimentos e seu sexo. A ausência de movimentos fetais, por sua vez, indicava uma gravidez de risco. Assim, a anatomia e a fisiologia da gestação e do feto compartilhadas pelos Munduruku conduziram suas avaliações sobre a existência ou não de risco para a saúde da mulher gestante. Com base nas práticas de autoatenção, observadas e relatadas, reflito a seguir sobre a saúde reprodutiva da mulher Munduruku.

Iara, uma de minhas anfitriãs, foi a primeira mulher Munduruku a me perguntar "já mexe?", e também a mais insistente. Houve uma manhã em que minha resposta negativa gerou uma evidente preocupação e tornou explícito que aquela questão envolvia algo mais do que mera curiosidade sobre os movimentos fetais. Quando eu disse que não sentia mexer, Iara franziu a testa e falou: "Mas tu já tá de quatro meses!". Eu lhe expliquei que não, pois, de fato, havia acabado de entrar no terceiro mês de gestação. Iara ficou em silêncio. Ceci, ouvindo nossa conversa, falou que logo mexeria. Então, Iara me perguntou: "Teu filho é para nascer quando?". Eu respondi que era para o mês de setembro, talvez início de outubro. Ela fez os cálculos, se convenceu de que eu estava no primeiro trimestre da gestação e mudou de assunto. Voltou a falar sobre uma conversa que tivemos dois dias antes sobre "filho de bicho".

Engravidar de bicho não era história mítica nem folclore para as mulheres Munduruku. Muitas delas contavam histórias de "gravidez de bicho", "filho de bicho", algumas sobre a experiência própria, para o seu desespero e o da família, outras sobre experiências de vizinhas ou parentes. Iara foi apenas mais uma das mulheres que compartilharam comigo a angústia de ter vivido uma "gravidez de bicho". Ela já era mãe de dois meninos quando teve uma "gravidez de bicho". Isso havia sido mais de oito anos antes. Ela só descobriu que estava grávida após um evento específico. Iara contou que foi jogar bola (futebol) na quadra com outras mulheres ao fim do dia. Estava de goleira quando levou uma bolada na barriga. Aquele "golpe" lhe causou muita dor e sofrimento. Foi para casa e o sangramento 
continuou. Um agente indígena de saneamento (Aisan), conhecedor de muitos remédios caseiros, recomendou que bebesse "sumo de algodão", pois se fosse menstruação ela pararia de sangrar. Sua mãe estava desconfiada de que era bicho porque ela tinha emagrecido ao invés de engordar, estava triste e não "sentia desejo". Então, ela tomou o sumo de algodão indicado. À noite sentiu uma "agonia forte" e, com o auxílio de sua mãe, foi ao penico e "saiu". A mãe de Iara não a deixou olhar. Depois lhe contou que "parecia uma boca, tipo arraia, mas só boca que mexia". Iara avaliou que tinha engravidado de "bicho" porque fora tomar banho na cacimba quando ainda "não estava muito boa da menstruação". 54

Figura 22 - Menino retirando água da cacimba

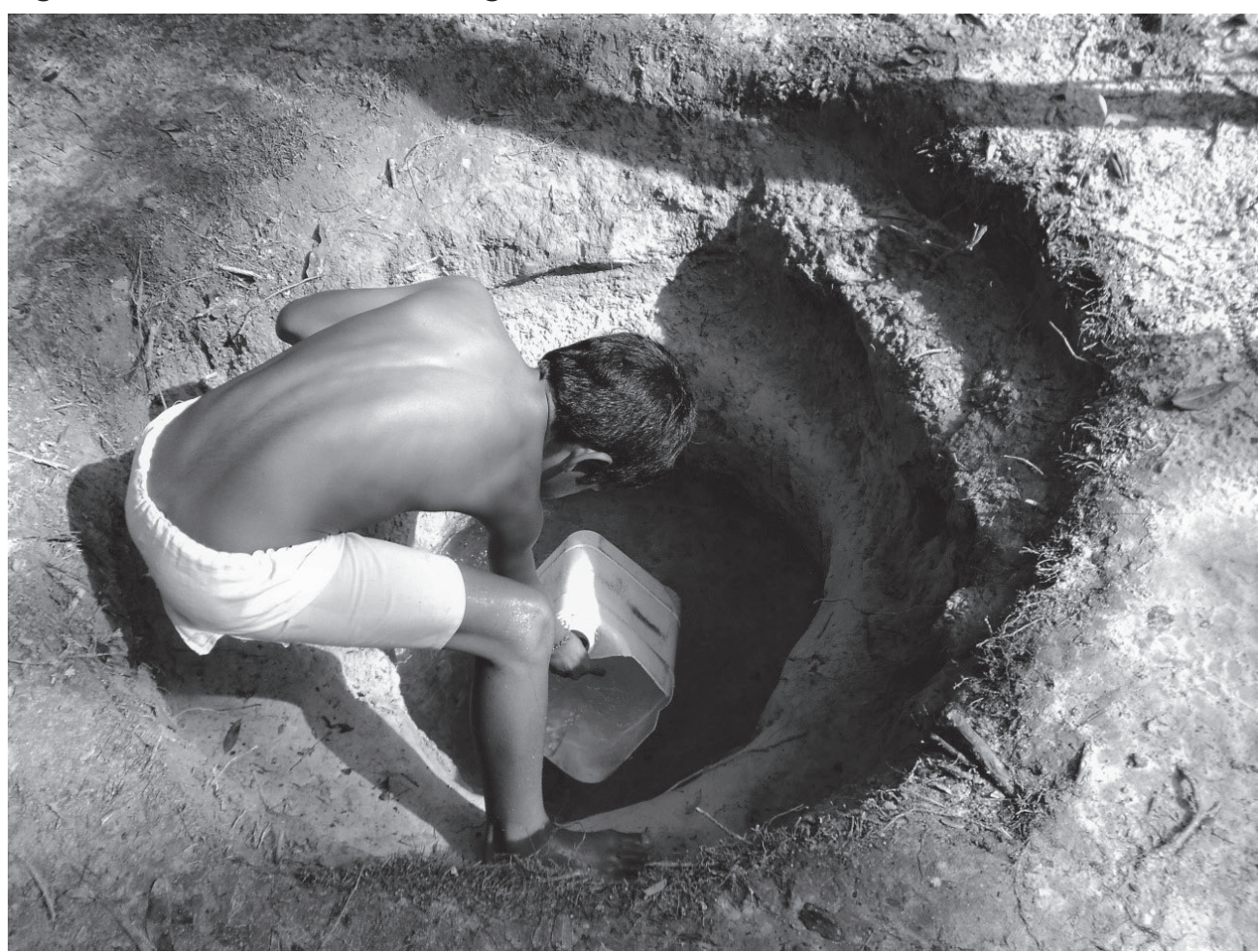

Foto Daniel Scopel.

Ela reconheceu que ter tomado banho menstruada na cacimba fora um "descuido". Desde aquele dia em que fora na cacimba, sua menstruação desceu muito pouco e, por isso, não desconfiou que estivesse grávida. Depois de "botar o bicho para fora", não fez curetagem, apenas tomou um "remédio purgante" preparado por sua mãe. Iara finalizou a narrativa com um longo suspiro e seu sorriso contido anunciava o alívio por ter saído com saúde desse triste episódio de sua vida.

Entre os Munduruku era explícito que a mulher menstruada devia "se guardar". Esperava-se que a mulher menstruada ficasse reclusa no interior da casa 
como prática de autoatenção ligada à sua própria saúde e à do grupo em geral, especialmente das crianças. O resguardo da menstruação instaurava uma dimensão espaço-tempo distinta do cotidiano, designava uma série de ações voltadas para fins específicos e articulava valores da cosmografia munduruku sobre a relação entre homens e mulheres, entre eles e os "seres encantados", os "donos" e os "espíritos" que habitam o cosmo.

Iara e Ceci me perguntaram, em diversas ocasiões, se eu havia menstruado e me pediram que eu as avisasse caso isso ocorresse. De fato, eu estava na cidade de Nova Olinda do Norte para fazer um breve levantamento de dados na Casa de Apoio à Saúde do Índio (Casai) quando menstruei pela primeira vez em trabalho de campo, de modo que, ao retornar para a aldeia, levei mais um ciclo para menstruar novamente. Minha menstruação não estava muito regular, por vezes eu completava um ciclo de trinta ou mais dias para menstruar novamente. Assim, ao início de meu trabalho de campo passou-se um longo período até que eu menstruasse pela primeira vez na aldeia, o que parece ter gerado ansiedade nas minhas anfitriãs. Certa vez, Ceci perguntou-me se eu estava menstruada e, após minha resposta negativa, contou-me um fato que ocorrera com sua nora.

Estávamos somente Ceci e eu, tomando café após o almoço. Havia um calendário de festas na TIKL dedicado a comemorar o dia do padroeiro da aldeia. Nessas festas, os moradores da aldeia anfitriã esperavam grande participação de parentes e moradores de outras aldeias e até mesmo daqueles que moravam na cidade. Em uma delas, a do dia das crianças, os moradores da aldeia Kwatá se organizaram para subir até a aldeia Malocão, a mais distante no rio Canumã. Parentes de Ceci vieram da cidade de Nova Olinda do Norte para a aldeia Kwatá para subir o rio até a aldeia Malocão. A mãe da nora de Ceci, que era da cidade, jogou "panos sujos de sangue" menstrual na beira do rio. No mesmo dia, a nora de Ceci começou a sentir dor de cabeça. Trouxeram-na para Kwatá. Os dias se passaram e ela não melhorava. A situação se agravou quando ela falou que tinha um homem querendo levá-la. No início, ela via o próprio marido, mas não era ele, porque ele ainda estava na festa. Assim, concluíram que se tratava de um boto. Ceci mandou um de seus filhos buscar a curadora Nair na aldeia Fronteira. Ele foi até o polo-base e junto com o piloto da lancha foram em busca da curadora. A curadora chegou, fez defumação e benzeu a mulher até levar o boto à exaustão, fazendo com que abandonasse a mulher. A curadora explicou que o pano sujo de sangue fez o boto "se agradar" da nora. O boto queria levá-la embora para o "encante". Ao final, a curadora mandou fazer um remédio de "banho de planta cheirosa", que deveria ser usado por três dias, e recomendou que a mulher não voltasse mais ao Malocão. 55

A narrativa de Ceci tinha claramente um propósito pedagógico. A mãe não cumpriu o resguardo e a filha sofreu as consequências da quebra das prescrições e restrições relativas às práticas de autoatenção à menstruação. Com essa narrativa, 
Ceci me alertava não apenas para os riscos que eu poderia correr se deixasse de cumprir as práticas de autoatenção relativas à menstruação, mas também para o fato de que eu estaria colocando em risco as pessoas próximas, caso não cumprisse o resguardo. Esse era o motivo pelo qual Ceci e Iara estavam solicitando para que eu as avisasse ao menstruar. Procurei tranquilizá-las, comprometendo-me a comunicá-las quando ocorresse.

Naquele momento, lembrei que Iara estava menstruada. Talvez por isso ela e Ceci estivessem me questionando uma vez mais. De fato, Iara me comunicara, dias antes, que estava menstruada ao falar sobre suas "dores nas cadeira", enquanto passava as mãos na cintura e no quadril. Nos dias seguintes, Iara não desceu para a beira, como costumava fazer rotineiramente para buscar água, banhar-se, lavar louças ou roupas. Iara tomou banho dentro de sua casa, no quarto, durante todos os dias da menstruação. Seu marido ou seus filhos traziam água em baldes de vinte litros na quantidade suficiente para ela se banhar. As louças também foram lavadas no jirau construído na sacada da casa de Ceci, e isso exigiu que os homens trouxessem mais água da beira. As roupas se acumularam até o dia em que já não havia mais impedimento algum para Iara descer à beira, certamente porque sua filha mulher ainda não tinha habilidade nem idade para lavá-las. Iara contou-me que ficava menstruada por cinco a sete dias, e que nesse período não ia para a beira, evitando passear pela aldeia. Durante sua menstruação, observei que ela também não foi trabalhar na roça nem na casa de farinha. Passava os dias em casa, cozinhava e limitava-se a circular no terreno entre sua casa e a de Ceci.

Quando as aulas iniciaram, Iara abriu uma exceção para não perdê-las. Ela estava cursando o ensino para jovens e adultos à noite e não deixou de ir às aulas na escola, que ficava bem próxima de sua casa. ${ }^{56}$ Notei que Iara tomava alguns chás, naqueles períodos, os quais me foram oferecidos mais tarde. Tratava-se de chá para diminuir o fluxo e o tempo de duração da menstruação. Outras mulheres ainda revelaram utilizar "remédio para curar" durante a menstruação. Esses remédios para curar foram utilizados com o propósito anticoncepcional, "para não engravidar" ou para controlar os intervalos entre uma e outra gravidez, conforme falou uma indígena da aldeia Niterói, que fora "curada para ter filhos de dois em dois anos". Independentemente da intenção específica, se para diminuir o fluxo e o tempo das regras ou como anticoncepcional, os remédios para curar ou os chás deviam ser ingeridos durante a menstruação. Alguns desses chás utilizados durante a menstruação também foram ingeridos ao longo do pós-parto como prática de autoatenção para sarar a "infecção no útero", como veremos mais detalhadamente no Capítulo 7.

No dia em que menstruei avisei a Iara e Ceci, que me recomendaram tomar banho dentro de casa, e não na beira. Era época de seca e estávamos tomando banho 
com a água da cacimba. Foi meu marido quem trouxe água para eu me banhar dentro de casa, o que foi um aprendizado para ambos. Daniel precisou desenvolver a habilidade necessária para carregar as vasilhas de água. Eu, por minha vez, tive que aprender a tomar banho dentro de casa, pois estava acostumada a tomar banho no rio, onde mergulhávamos e despejávamos água sobre o corpo com o auxílio de uma cuia, ou na água da cacimba, de onde retirávamos a água para encher uma grande bacia, localizada a uma distância adequada para não escorrer água de volta para a cacimba, e com a cuia jogá-la em abundância sobre o corpo. Ceci explicou-me que para tomar banho dentro de casa bastava fechar as janelas e se posicionar de cócoras ou de joelhos para despejar no corpo a água que escorreria por entre as frestas do assoalho para o lado de fora da casa. E foi assim que se passaram todos os dias da menstruação.

Naquele momento, aprendi que uma mulher menstruada deveria evitar ir para a beira fosse para tomar banho ou para qualquer outra atividade como buscar água potável, lavar louças ou roupas no rio em período de cheia. As mesmas proibições se aplicavam à mulher menstruada no período da seca, quando todas essas atividades eram realizadas na cacimba. No segmento residencial onde morei durante a maior parte do trabalho de campo, havia em média dez mulheres em período fértil, das quais cinco estavam ou de resguardo do parto ou grávidas. Observei que logo atrás da casa de Araci e Itamar, que viviam com seus 12 filhos e um genro, havia uma construção na parte externa. Tratava-se de um cercado onde, por vezes, eu via as filhas do casal tomarem banho. Araci e Itamar tinham uma família numerosa e aquele cercado fora construído para as mulheres tomarem seus banhos no período da menstruação, já que havia muitas pessoas na casa. Quando não estavam menstruadas, as filhas de Araci e Itamar se banhavam, a depender da época do ano, na beira ou nas proximidades da cacimba, como todos os demais.

Os Munduruku reconheciam que homens e mulheres eram diferentes e que a diferença central estava no fato de que as mulheres menstruavam. Nas palavras de um Munduruku, "mulher nunca foi igual ao homem, porque sempre tem aqueles dias no mês que fica menstruada e fica presa". Esse índio estava contando sobre a noite em que atirou em um boto que passeava entre sua casa e a de seus parentes. Era noite, e ao escutar barulhos ao redor da casa, pensou que fosse seu cunhado, mas desconfiou e foi olhar. Viu um homem branco e tratou de pegar sua arma. Chamou os cachorros e pôs-se em direção à beira do rio. Chegando mais perto, viu que aquele homem branco estava de pé "na prancha, de frente para o rio e de costas para a terra". Prancha é a tábua de madeira que os Munduruku fixam no rio, utilizada para lavar louças e roupas. Seu tiro foi certeiro, apesar da noite escura. Quando se aproximou do rio, sentiu um pitiú (cheiro forte, desagradável), mas não viu nada. No dia seguinte, contou que viu, junto com outros homens, a caminho do jogo de futebol, um bicho, um boto morto na água. Ceci finalizou 
aquela conversa de fim de tarde dizendo que a mulher na menstruação cheira como um ananás. Ananás é um abacaxi muito doce e com um cheiro agradável. Ceci concluiu dizendo que o sangue menstrual é "pitiú para gente, mas para eles é que nem ananás". Eles eram os botos ou os "seres encantados", ou os "donos" que habitavam espaços específicos no cosmo, fosse no rio, nos igarapés ou em algum olho d'água de cacimba.

Os esforços das mulheres Munduruku para cumprir o resguardo da menstruação adquirem significado quando compreendemos que os Munduruku coabitavam um cosmo junto com diversos outros seres (espíritos, mães, donos, encantados, botos, cobras e kakerewat), cujo contato, possivelmente, resultava em enfermidades, infortúnios e até em morte para todos. Na perspectiva munduruku, há risco de vida para suas mulheres, seus homens e suas crianças devido à potencialidade das interações com esses demais seres. Na vida da aldeia, as fronteiras entre os domínios humanos e os dos demais seres se dilui. Entre as muitas formas de diluição das fronteiras está o cheiro do sangue menstrual. Para os Munduruku, o cheiro de sangue menstrual era pitiú, palavra utilizada para designar cheiros fortes e desagradáveis como, por exemplo, o cheiro de peixe nas mãos após limpá-los ou comê-los. Entretanto, na perspectiva dos botos, era doce "que nem ananás". Homens e mulheres Munduruku eram unânimes ao afirmar que os botos eram atraídos pelo cheiro do sangue menstrual. Os botos poderiam se agradar tanto da mulher menstruada quanto de qualquer outra pessoa próxima. Isso era, de fato, um saber compartilhado há muitas gerações entre os Munduruku. Experiências pessoais, contadas por suas avós ou observadas pessoalmente pelos Munduruku, permitem sublinhar a característica volátil do sangue menstrual, isto é, sua capacidade de se propagar e de deixar um rastro. Os Munduruku sabiam que a circulação sobre o rastro deixado pela mulher menstruada representava fonte de perigo e contaminação. Nesse sentido, as práticas de autoatenção relativas à menstruação como, por exemplo, banhar-se dentro de casa, evitar ir à beira ou à cacimba, tinham o propósito de manter a saúde da mulher menstruada e dos demais membros do grupo, especialmente das crianças.

Em minha experiência de campo com os Munduruku, eles frequentemente evocaram o descumprimento das interdições, prescrições e restrições atinentes à menstruação como causa da irrupção de doenças, infortúnios e mortes ("mau-olhado de boto", "ser levado para o encante", "assombro de bicho", "filho de bicho"). O cheiro do sangue deixado no rastro por onde a mulher menstruada passou, especialmente pela beira, atrairia o boto do "encante". O risco instalado quando não se cumpria o resguardo recaía especialmente sobre as crianças e as mulheres. As crianças que circulassem sobre o rastro da mulher menstruada sofreriam ataques dos encantados e correriam o risco de serem levadas para o "encante". Os sintomas de "mau-olhado de bicho" relatados foram medo, tremores no corpo, febre 
e visões. Nesses casos, somente o pajé poderia curar o enfermo por meio de rezas e da prescrição de banhos. O tratamento era longo e consistia em três a sete rezas e banhos toda sexta-feira.

Para a mulher que nos dias de suas regras fosse ao rio ou à cacimba, o risco por não cumprir o resguardo da menstruação era de engravidar de bicho, isto é, gestar e parir um "filho de bicho". A mulher menstruada que se banha na beira ou na cacimba pode ser fecundada tanto por boto quanto por peixes ou pela "mãe da cacimba", que é o "dono da cacimba", e isso ocorre durante o sonho. Há relatos de mulheres que tiveram filhos de botos e de outros seres encantados, como cobras. Esses casos de gravidez de bicho tiveram os seguintes desfechos: aborto, a morte da criança (o mais comum é o "filho de bicho" nascer morto ou ser "levado para o fundo" por seu pai encantado, logo após o nascimento) e a morte da mulher, uma vez que a relação contínua com os encantados leva a doenças graves, nem sempre curadas pelos pajés. 57

Optei por descrever as práticas de autoatenção relativas à menstruação para assinalar os riscos para a saúde da mulher e do grupo como um todo advindos da inobservância dessas práticas específicas ao resguardo da mulher menstruada. Cumpre notar que o sangue do parto também é perigoso, pois tem as mesmas características do sangue menstrual segundo os significados simbólicos atribuídos pelos Munduruku. Interessa-me destacar sobretudo uma preocupação constante na vida das mulheres Munduruku relativa à virtual gravidez e gestação de um "filho de bicho", para abordar, principalmente, os saberes sobre a anatomia e a fisiologia relativos à gestação. Ao mesmo tempo que o sangue menstrual é fonte de vida e contribui para consolidar a união de um casal, pois de sua junção com o sêmen formam-se "crianças", também é fonte de perigo, dado que pode formar "filho de bicho". Da relação sexual entre uma mulher menstruada e um bicho, ocorrida em sonho, podem nascer seres cujo corpo teria forma meio humana, meio animal por exemplo, "corpo de cobra e cabeça de criança" ou "corpo de gente e tronco e cabeça de boto".

\section{Pegar barriga}

Embora não tenha deixado de cumprir o resguardo da menstruação, Iara estava novamente temerosa de uma possível "gravidez de bicho", dados os sinais que vinha avaliando durante a gestação, como não "sentir desejo", não sentir mexer e "sentir uma agonia no estômago". Tendo avaliado as sensações corporais que tinha ou não e considerando suas experiências anteriores de gestação, ela decidiu ir "pegar barriga" com sua cunhada Araci. Iara e Araci compartilharam comigo o que vinha acontecendo naqueles dias em distintos momentos. Esse caso serve como 
exemplo para sublinhar os saberes sobre anatomia e fisiologia relativos à gestação, compartilhados pelos Munduruku a partir da prática de "pegar barriga".

Araci "pegou a barriga" da Iara e concluiu que não era "filho de bicho". Araci tinha experiência em partejar, em "puxar a mãe do corpo" e em "pegar barriga". Explicou-me que quando "pega barriga já dá pra saber se é bicho ou não". Esse saber reside na anatomia do feto, isto é, em um modelo cultural do corpo humano. Apalpar a barriga permitiria identificar que a forma do "filho de bicho" não tem a mesma consistência de uma "criança". A consistência do feto humano, diferentemente da consistência do "filho de bicho", seria firme, semelhante à de um objeto sólido, contido e uno. Ao contrário, o "filho de bicho" teria uma consistência flácida, instável e desmembrável, e, ao ser apalpado, "se espalha entre os dedos", "espalha na barriga", "como se ele desmanchasse" entre os dedos e para os lados. Além da anatomia do feto, as mulheres Munduruku também compartilham um saber acerca de um conjunto de sinais e sintomas indicativos da gestação de um "filho de bicho". Então, se a mulher está "grávida de bicho", ela "emagrece, fica fraca, sente dores no pente". Araci me explicou que o "pente da mulher" fica abaixo do umbigo e nas laterais.

As mulheres Munduruku afirmavam ir "pegar barriga" a partir do momento em que descobrissem estar grávidas, isto é, a partir da cessação da menstruação. Iara foi "pegar barriga" ao final do terceiro mês de gestação. E a principal motivação, naquela fase inicial, foi o fato de que seu bebê não se mexia. Os movimentos fetais, além de sinalizarem uma gravidez saudável, forneciam também indícios do sexo da criança. Segundo homens e mulheres Munduruku, o filho homem "se forma" logo no primeiro mês e pode, a partir desse momento, se movimentar. Quando pedi para explicarem melhor o que queriam dizer com "se formar", eles falaram que o corpo do filho homem já teria todos os membros formados corretamente desde o primeiro mês de gestação, como se fosse uma dessas "bonequinhas" de brinquedo "bem pequenas". A filha mulher, por sua vez, levaria até o quinto mês para "se formar", para "amadurecer", podendo movimentar-se a partir do terceiro mês de gestação. Até amadurecer, a filha mulher teria a consistência de "uma bola, já durinha", portanto ainda sem a forma do corpo humano, com tronco, braços, dedos, pés etc. As mulheres Munduruku também costumavam "pegar barriga" para verificar se o feto estava na posição correta e, se necessário, posicioná-lo no "nascedouro". Durante toda a terceira etapa da pesquisa de campo, Iara foi "pegar barriga". Inicialmente, "pegou" porque estava desconfiada da gestação "de bicho", depois porque a criança não estava na posição correta, pois estava atravessada. Ela foi "pegar barriga" com sua cunhada Araci e também com o curador Porã. Ele lhe comunicou a posição do bebê, recomendando-lhe que fizesse o parto no hospital da cidade. Durante os três meses da última etapa de pesquisa de campo, Iara foi "pegar barriga" com o curador Porã a cada mês e estava convencida de que faria 
o parto hospitalar, na cidade de Nova Olinda do Norte, pois a criança não voltava para a posição correta no "nascedouro". Além disso, a experiência dos partos de seus quatro filhos também reforçava sua decisão de parir na cidade. Ela contou que tinha dificuldades para parir, sentia muita dor e que seus partos eram demorados. Dois filhos nasceram no hospital e dois na aldeia. Para Iara, os partos na cidade foram mais tranquilos.

\section{Notas}

43 Um caso exemplar do processo de aprendizado de um conhecimento específico e domínio de determinada técnica por meio da experiência vivida é a emergência dos curadores pajés Munduruku na TIKL. Conforme analisou Scopel (2013), entre os Munduruku da TIKL tornar-se pajé envolve um processo de cura de uma doença grave. É através da experiência desse processo de cura feito por outro pajé experiente que se identifica o "dom" da pajelança e se "endireita a linha" do novo pajé. O pajé Munduruku, de modo semelhante aos outros curadores Munduruku (rezadores, benzedores, "pegador de desmentidura", parteiras, entre outros), afirma que seu conhecimento vem de um "dom", para enfatizar que não se trata de um saber aprendido em livros. Todavia, o desenvolvimento da habilidade de curador resulta do conhecimento acumulado em sua rotina de "trabalho", em suas experiências de cura, da troca de saberes com espíritos ou encantados. A saúde do pajé Munduruku vem com o exercício de seu "trabalho", por meio do qual ele aperfeiçoa sua habilidade e seus conhecimentos. Scopel (2013) faz uma análise detalhada da emergência de curadores pajés entre os Munduruku da TIKL e também uma descrição do conjunto de práticas de autoatenção diárias que um pajé deve realizar para se resguardar de atentados dos encantados, isto é, para se manter saudável. De modo semelhante, Pérez-Gil (2007b: 59-60) também registra que entre os Yaminawa, na Amazônia peruana, o aprendizado de determinadas técnicas como caçar, pescar, desenhar, utilizar plantas medicinais, entre outras, "acontece sempre na prática". McCallum (1999: 162-164) também enfatiza a importância da prática na aquisição de conhecimentos e habilidades ao tratar da produção de pessoas "genderizadas" entre os Kaxinawá. A autora apresenta o modo como as habilidades sociais e as aptidões de gênero se inscrevem no corpo, resultantes de um processo de "aquisição corporal de conhecimento".

44 A aldeia Niterói fica ao sul da TIKL, subindo o rio Canumã. Segundo o agente indígena de saúde, ali moram aproximadamente 94 indígenas. Nossa estadia na aldeia Niterói foi de apenas seis dias, conforme havíamos acordado com nosso anfitrião, o curador Guaraciaba.

45 É interessante notar que também para os Wari' (Pakaa Nova), de Rondônia, acredita-se que a letargia e a preguiça (a qual implica no desengajamento da produção de comida e reciprocidade) enfraquecem o sangue e causam doença, em ambos os sexos (Conkli $G$ Morgan, 1996: 676).

46 Segundo o conceito weberiano de relação social (ver nota 8, na Introdução), outro ponto a destacar é o caráter probabilístico da relação social, o que nos ajuda a entender a magnitude do "abalo de criança", conforme veremos no próximo capítulo. Isto é, podemos 
admitir, assim como fazem os Munduruku, que um homem pode sentir "abalo de criança" durante a gestação.

47 Esta análise dos sentimentos e comportamentos apropriados a determinada categoria de pessoa foi inspirada em textos de Roberto Da Matta e de Peter Gow. Ao analisar a etiqueta das relações sociais na vida cotidiana entre os Apinayé, Da Matta (1976: 77-80), encontrou também relações marcadas pelo sentimento de "vergonha". Por sua vez, Gow (1989: 57), ao analisar o modo de produção de comida e as relações maritais entre os nativos do Baixo Urubamba, também se referiu às relações de respeito e demanda como constituidoras de comportamentos ideais entre parentes.

48 Uma situação inusitada, pois, apesar de ter conhecimento do ideário do "casal grávido" (Salem, 1989) comum entre a camada média urbana brasileira que compartilha uma visão psicologizada da gestação, do feto, do parto, na qual se valoriza a igualdade dos gêneros masculino e feminino nas experiências de gestar e parir um filho, de modo geral a mulher gestante continua sendo o foco de direitos (atendimento prioritário, com vigor de lei federal de 2000) e de deveres (as consultas de pré-natal) no cenário nacional. E, de maneira geral, fora da aldeia, amigos, colegas de trabalho e mesmo desconhecidos na rua dirigiam sua atenção - olhares, comentários e perguntas - para a minha barriga, e não para o estado do meu esposo, pai da criança.

49 Essa bebida fortificante pode ser utilizada em qualquer momento da vida de um homem Munduruku. Trata-se de um elixir feito com a raspa da raiz de saracura misturada com água e batida até formar uma espuma que faz lembrar a cerveja, como eles mesmos afirmam. No entanto, não é uma bebida alcoólica. É, contudo, considerada uma bebida forte, com efeitos colaterais imediatos que precisam ser contidos pelo banho frio, que, por sua vez, os reverte em benefícios energéticos e fortificantes. Diz-se que a bebida dá ânimo para o trabalho, fortalece a imunidade, deixa o homem forte e ágil. A dosagem correta da raiz irá determinar seus efeitos benéficos, ao contrário da alta dosagem, que tem efeitos tóxicos, segundo os Munduruku. A saracura também é utilizada como prevenção da malária. Ver Scopel (2013: 198) sobre o uso de remédios caseiros como prática de autoatenção.

50 Sobre agência (agency), compartilho da concepção de Ortner (2006: 134), para quem esta "nunca é uma coisa em si mesma, mas é sempre parte de um processo do que Giddens chama de estruturação, o fazer e refazer de ampla formação social e cultural" (tradução minha). Agência implica processo, intencionalidade e regimes de poder. Mais precisamente, a noção de agência pressupõe uma relação dialética entre três pontos: 1) a sociedade é estruturada e tem práticas e relações sociais sistemáticas; 2) essas estruturas e relações sistemáticas coagem os sujeitos e constituem os instrumentos e elementos que moldam suas subjetividades; 3) contudo, os sujeitos não são passivos, eles têm agência nessas relações sistemáticas, eles agem, reproduzem, resistem e transformam tais relações sociais e as estruturas. Desse modo, agência pode ser entendida como ação criativa e intencional exercida sempre em contexto, marcado por redes de solidariedade e/ou conflito. E a intencionalidade, bem como os regimes de poder, por sua vez, remete a relações que emergem em espaços sociais predicados por princípios de diferenciação e valorização histórica e culturalmente engendrados. Assim, se em uma perspectiva as práticas sociais tendem a reproduzir estruturas públicas resultando em reprodução social, em outra há também elementos que engendram mudança na estrutura social. A ênfase 
no pressuposto de que o mundo social é feito pela atividade humana, pela prática social, não pode prescindir da suposição de que o mundo pode ser desfeito e refeito também através das práticas sociais.

51 Ver Seeger (1980: 129) sobre as teorias de concepção entre os Suyá, para os quais apenas o sêmen do homem contribuiria para a formação da criança. Entre os Apinayé também haveria a noção da necessidade de "copular muito para formar um novo ser humano"; todavia, homem e mulher contribuiriam com substâncias para formar o corpo do feto, sêmen e sangue menstrual, respectivamente (Da Matta, 1976: 83, 84). Entre os Krahó, a criança pode ser gerada por mais de um homem e todo homem que contribui com seu sêmen é responsável pela "formação do corpo da criança" (Melatti, 1978: 55). Entre os Yaminawa também haveria a ideia de paternidade múltipla, isto é, de que todos os homens que tiveram relação sexual com a mulher durante a gravidez contribuiriam para a formação do corpo da criança (Pérez-Gil, 2007b: 64). Murphy e Murphy (2004: 187) sugerem que para os Munduruku do Alto Tapajós a matéria-prima do feto seria o sêmen. Segundo o casal Murphy, o feto seria formado por meio da acumulação de sêmen no útero da mulher através da repetição de intercurso sexual num período de vários dias. Certamente uma revisão bibliográfica mais extensa sobre o tema evidenciaria muitos outros exemplos. Porém, a intenção aqui não é fazer uma lista de exemplos, apenas chamar a atenção do leitor para o fato de que os estudos antropológicos apresentaram uma diversidade de teorias de concepção alternativas àquelas divulgadas pela abordagem biomédica praticada nos serviços de saúde.

52 Utilizo o termo economia de subsistência inspirada em Gow (1989), conforme definido no Capítulo 2.

53 Conklin e Morgan (1996: 171) também sugeriram que entre os Wari' "o feto encapsula relações entre sua mãe e seu pai e, por extensão, entre seus respectivos grupos de parentesco" (tradução minha), ao observar que a gestação é um processo social que repercute na geração do corpo e da pessoa Wari': para os Wari', o feto também já tem características como consciência e capacidade relacional, produzidas por meio das relações sociais.

54 Cacimba é um poço raso, cavado na areia da praia no período de seca, de onde verte água fresca. É usada somente nesse período, quando a água do rio está muito quente e suja.

55 Scopel (2013: 183-191) analisou diversos itinerários na busca por curadores, os diagnósticos e os tratamentos entre os Munduruku da TIKL, incluindo aqueles que tratam das enfermidades advindas do contato com os botos. Em um caso, um rapaz sofrera de "assombração por causa de uma bôta" (Scopel, 2013: 188, grifos do original), e parte do tratamento incluía a prescrição de não retornar ao local onde se dera o contato.

56 A educação de jovens e adultos era uma iniciativa da Prefeitura de Borba, que contratava professores indígenas para ministrar as aulas no período noturno.

57 O leitor encontrará em Belaunde (2005) uma revisão de várias etnografias feitas entre os povos indígenas amazônicos, cujo eixo de análise foi a importância do sangue e dos manejos a ele relacionados na condução da vida social, na construção dos gêneros, na fabricação dos corpos e das pessoas. A autora sugeriu que o sangue deveria ser entendido como operador que "reúne o biológico, o mental e o espiritual", posto que "o (...) manejo do fluxo de sangue (...) é um processo constitutivo não somente da fertilidade, 
mas da saúde, do trabalho, da criatividade, do bem-estar, da religiosidade, da identidade pessoal e das relações interétnicas" (Belaunde, 2005: 18-19, tradução minha). De modo semelhante, as análises de Conklin e Morgan (1996) e Conklin (2001) também apontaram o sangue e as relações de sangue entre os Wari' como produtos sociais, expandindo assim o sentido da noção de sangue para fronteiras além da matéria biológica. Os autores sugeriram que as "relações de sangue" entre os Wari' compreenderiam os laços entre os membros de uma união marital (entre marido e esposa), de uma família nuclear, de uma rede de parentesco, de um subgrupo territorial, de um grupo étnico e entre o xamã e o espírito do seu animal companheiro (Conklin G Morgan, 1996). Em certa medida, esses textos contribuem para iluminar nossa compreensão sobre a noção de sangue entre os Munduruku, posto que as qualidades dessa substância tenham o poder de diluir fronteiras entre humanos e não humanos, além de fazê-la emergir como elemento formador de novos seres Munduruku, os quais encapsulam relações construídas pela partilha de sangue, sêmen, alimento, gordura, vitalidade, apoio mútuo e trabalho. 


\section{Participação da Gestante Munduruku no Programa de Assistência Integral à Saúde da Mulher}

As práticas de autoatenção relativas à gestação manejadas pelos Munduruku da Terra Indígena Kwatá-Laranjal (TIKL) até aqui apresentadas sintetizam o saber local sobre concepção, gestação e parto e diferem das noções de fisiologia e anatomia da biomedicina. Entretanto, isso não impedia que as mulheres Munduruku participassem dos programas voltados para a saúde da gestante, como o acompanhamento pré-natal, promovidos pelo serviço de saúde via Subsistema de Atenção à Saúde Indígena (Sasi), sob a gestão da Secretaria Especial de Saúde Indígena (Sesai), do Ministério da Saúde (MS). Desde a ampliação da cobertura da atenção primária no interior das terras indígenas brasileiras, inclusive na TIKL, uma das lacunas na execução das ações programáticas foi a questão logística, além da rotatividade dos profissionais da saúde, suas eventuais ausências e a falta de capacitação para atuar em um contexto interétnico (Dias-Scopel, 2005; Silva, 2011; Diehl, Dias-Scopel G Langdon, 2012). Neste capítulo apresentarei dados de observação participante realizada junto às mulheres da TIKL, às gestantes na Casa de Apoio à Saúde do Índio (Casai) e às Equipes Multiprofissionais de Saúde Indígena (EMSIs) que atuavam no Polo-Base Kwatá e no Polo-Base Laranjal, para que o leitor conheça os obstáculos para a oferta e o uso dos serviços de pré-natal às mulheres indígenas.

Antes, porém, convém explicar minimamente o que é o programa pré-natal. Assim procedendo, desnaturalizamos uma prática específica, relacionada a um determinado campo de saber-poder, permeada por tecnologias e histórias específicas, intervenções e formas de controles reguladores, micropoderes nas interações cotidianas e marcada pela racionalidade burocrática e capitalista. O pré-natal é um conjunto de práticas biomédicas voltadas para a redução da mortalidade maternoinfantil, iniciadas durante a gestação e finalizadas com consultas no pós-parto. No Brasil, trata-se de um programa gerido pela Área Técnica de Saúde da Mulher, sob a coordenação do Ministério de Saúde, responsável por formular a Política Nacional de Atenção Integral à Saúde da Mulher (PNAISM). As diretrizes e os princípios dessa política foram consolidados pelo MS em 2004. A atenção à saúde da mulher e adolescente indígena é mencionada no documento como um dos objetivos 
específicos da PNAISM no Brasil (Brasil, 2004a: 72). Nele, dados epidemiológicos sobre as condições de saúde da mulher indígena e os princípios de humanização e qualidade da atenção são considerados elementos indispensáveis para a melhoria dos níveis de resolutividade das ações de cobertura, assistência e promoção da saúde e daquelas voltadas para os problemas de maior incidência, entre os quais a mortalidade materna, cujas principais causas eram "a hipertensão arterial, as hemorragias, a infecção puerperal e o aborto, todas evitáveis" (Brasil, 2004b: 27). Acredita-se que 92\% das causas de mortalidade materna seriam evitáveis, e a atenção ao pré-natal teria importante papel a desempenhar nesse cenário (Brasil, 2004b: 26-30).

O Brasil segue as recomendações da Organização Mundial da Saúde (OMS) para a normatização das práticas de saúde da atenção ao pré-natal (Brasil, 2005). Em termos gerais, a atenção ao pré-natal consiste na promoção de ações para a prevenção e detecção de riscos para a saúde tanto da mulher gestante quanto do feto, nos períodos da gestação e do pós-parto, e na atenção à puérpera e ao recém-nascido, incluindo o tratamento de eventuais intercorrências. Isso é feito mediante uma série de procedimentos que incluem desde consultas médicas para a verificação do estado de saúde da gestante e para o acompanhamento do desenvolvimento do feto por meio de exames clínicos e laboratoriais e de imunização. A organização desses serviços é responsabilidade dos três níveis de gestão: federal, estadual e municipal. As ações da atenção ao pré-natal, segundo o manual técnico do MS Pré-Natal e Puerpério: atenção qualificada e humanizada (Brasil, 2005), incluem, prioritariamente: história clínica da gestante, exame físico e exames complementares.

A história clínica se fundamenta na anamnese e permite identificar desde dados socioeconômicos até a investigação de histórico de doenças familiares ou pessoais, entre outras questões (Brasil, 2005). Segundo esse manual técnico, o exame físico incluiria: determinação do peso e da altura; medida da pressão arterial; inspeção da pele e das mucosas; palpação da tireoide e de todo o pescoço, região cervical e axilar (pesquisa de nódulos ou outras anormalidades); ausculta cardiopulmonar; determinação da frequência cardíaca; exame do abdômen; exame dos membros inferiores; pesquisa de edema (face, tronco, membros); exame de mamas; palpação obstétrica e identificação da situação e apresentação fetal; medida da altura uterina; ausculta dos batimentos cardíacos fetais; inspeção dos genitais externos; inspeção das paredes vaginais; inspeção do conteúdo vaginal; inspeção do colo uterino; coleta de material para exame colpocitológico (preventivo de câncer), toque vaginal. Os exames complementares, ainda de acordo com o Manual, deveriam ser solicitados na primeira consulta e abrangeriam: dosagem de hemoglobina e hematócrito; grupo sanguíneo e fator Rh; sorologia para sífilis (VDRL); glicemia em jejum; exame sumário de urina; sorologia anti-HIV; sorologia para hepatite B; sorologia para toxoplasmose. É indicada também a solicitação de exames comple- 
mentares ainda na primeira consulta do pré-natal, conforme avaliação específica de cada caso. Gostaria de citar, por exemplo, o exame protoparasitológico, indicado "sobretudo para mulheres de baixa renda", e a ultrassonografia obstétrica. Entretanto, ainda que se admita o potencial da ultrassonografia obstétrica para "melhor determinação da idade gestacional, deteç̧ão precoce de gestações múltiplas e más formações fetais clinicamente não suspeitas", destaca-se que "a sua não realização não constitui omissão, nem diminui a qualidade do pré-natal" (Brasil, 2005: 29). Isso não se aplicaria aos casos em que se pretenda investigar alguma suspeita sobre o desenvolvimento da gestação e do feto no período tardio da gestação.

Pretende-se que esses procedimentos relativos ao pré-natal sejam uma referência para a organização da rede assistencial, a capacitação profissional e a normatização das práticas de saúde segundo princípios e diretrizes apresentados pelo MS brasileiro, inclusive para o atendimento das populações indígenas. Ainda segundo o documento normatizador, indica-se a realização de, ao menos, seis consultas nas ações de acompanhamento pré-natal e o registro das gestantes no cadastro nacional do Sistema de Acompanhamento do Programa de Humanização no Pré-Natal e Nascimento (SispreNatal).

Na TIKL, as ações do pré-natal se iniciavam nos polos-base localizados no interior das aldeias e se estendiam a unidades do Sistema Único de Saúde (SUS) na cidade de Nova Olinda do Norte para a realização de determinados exames de sangue, de fezes e de urina, por exemplo. Iara estava grávida de cinco meses quando foi encaminhada para Nova Olinda do Norte para realizar exames. Foi levada pelo motorista da EMSI, junto com outras gestantes que também tinham exames agendados. As gestantes Munduruku que acompanhei realizaram exames de urina e de sangue coletados na cidade de Nova Olinda do Norte. O transporte foi realizado pelos serviços do polo-base, que agendou dias específicos para levar todas as gestantes das aldeias. Note-se que o transporte foi feito pelo rio, com a lancha da EMSI, a partir da aldeia em que o polo-base estava localizado. As gestantes das demais aldeias foram transportadas até o polo-base com o auxílio do agente indígena de saúde (AIS), em geral com sua rabeta (canoa) de uso particular abastecida com recursos (considerados insuficientes) providos pelo Distrito Sanitário Especial Indígena (DSEI). O tempo de viagem até a aldeia onde se localizava o Polo-Base Kwatá podia chegar a dez horas, a depender da distância da aldeia, se o transporte fosse feito de rabeta. Assim, o deslocamento era difícil e envolvia riscos, fosse de rabeta ou de lancha, pois podia levar muitas horas, sem coletes salva-vidas e com exposição às intempéries, sobretudo sol intenso e chuva.

As gestantes foram para Nova Olinda do Norte e voltaram para a aldeia Kwatá no mesmo dia. Ao chegar em casa, Iara compartilhou comigo e com Ceci sua frustração com os exames realizados, pois "pensava que ia fazer ultrassom". Quando encerrei a pesquisa de campo, Iara estava com sete meses de gestação 
e não havia feito nenhuma ultrassonografia obstétrica. Embora ela tenha ficado frustrada por não tê-lo feito, vimos que esse exame não figura como prioridade nas ações básicas mínimas nos serviços de acompanhamento pré-natal, segundo recomendações do MS. Todavia, ela e as demais gestantes Munduruku não deixaram de fazer o exame por tal motivo, e sim porque o único aparelho de ultrassonografia na cidade de Nova Olinda do Norte estava quebrado durante o período de minha pesquisa de campo.

Dado o fato de estar grávida de três meses, quando retornei para a última etapa da pesquisa de campo eu também participei das ações do pré-natal no Polo-Base Kwatá. Embora já tivesse realizado duas consultas na cidade de Florianópolis, com um médico ginecologista e obstetra particular, e feito uma bateria de exames físicos e complementares, além de uma ultrassonografia obstétrica, só fui inscrita no SispreNatal quando da consulta no Polo-Base Kwatá. Lá ganhei um Cartão da Gestante, no qual foram registrados os resultados dos meus exames complementares previamente feitos e as informações sobre os exames físicos realizados nas demais consultas, bem como a orientação para cumprir ao menos seis consultas de "pré-natal". As ações do pré-natal realizadas no polo-base foram feitas pela enfermeira da EMSI e incluíam controle do peso, aferição da pressão, medição da altura uterina e palpação obstétrica. Além disso, na primeira consulta fiz também a imunização para influenza, a última dose da vacina para hepatite e a dose de reforço para tétano. Esses foram os procedimentos-padrão que toda gestante Munduruku recebeu ao acessar os serviços de acompanhamento pré-natal no Polo-Base Kwatá, incluindo ainda a suplementação com sulfato ferroso e, caso necessário, a disponibilização de antiácidos.

A enfermeira da EMSI lamentava o fato de que alguns exames recomendados pelo MS brasileiro, que inegavelmente contribuem para prevenir ou diminuir os riscos de uma complicação na gestação e no parto e para garantir o bem-estar da mãe e do bebê, não fossem realizados na cidade de Nova Olinda do Norte, devido à precariedade da infraestrutura e à inexistência de alguns serviços do SUS local. Na época da pesquisa de campo, por exemplo, as mulheres indígenas, e provavelmente toda a população usuária do SUS daquela cidade, passaram a gestação sem realizar a sorologia para as principais infecções congênitas (por exemplo, sífilis, HIV e hepatites B e C). A falta de realização desses exames é um indicador da baixa qualidade das ações de pré-natal (Brasil, 2004a: 28). Assim, evidencia-se uma oferta deficitária às mulheres indígenas, em razão não somente da inadequação dos serviços prestados pela EMSI e pelo DSEI-Manaus, mas também da precarização dos serviços prestados nas demais redes do SUS no nível municipal. Vale lembrar que em 2004 o MS brasileiro firmou o Pacto Nacional pela Redução da Mortalidade Materna e Neonatal, no qual a ampliação da oferta de exames laboratoriais e de tratamento para sífilis na gestação e sífilis congênita apareceram entre as ações a serem adotadas para 
a redução da mortalidade materna e neonatal e que o estado do Amazonas é uma das unidades federadas que aderiram a esse pacto (Brasil, 2004c).

A maior dificuldade dos profissionais da EMSI, durante a pesquisa de campo, para a promoção das ações do pré-natal foi garantir a realização de seis consultas às gestantes indígenas. No Polo-Base Laranjal, por exemplo, houve, no ano de 2010, o ingresso de três gestantes no SispreNatal com sete meses de gestação. Isso significa que a primeira consulta delas nos serviços do pré-natal só aconteceu no sétimo mês de gestação. E essas gestantes só acessaram os serviços do pré-natal porque a EMSI estava em campanha de vacinação na aldeia onde moravam. Aliás, as campanhas de vacinação, segundo os membros das EMSI, eram a oportunidade de eles se deslocarem do polo-base até as aldeias e, então, oferecer a atenção primária. Isso porque o deslocamento da EMSI para a atenção primária, incluindo o acompanhamento das gestantes no pré-natal, para as aldeias adstritas ao controle de cada polo-base no interior da TIKL envolvia recursos e logísticas cuja demanda não era suprida. Cito, ainda, a falta de infraestrutura adequada para a realização dos serviços de saúde e, principalmente, para acomodar os profissionais da EMSI nas demais aldeias. Esses eram pontos considerados relevantes pelos profissionais da EMSI e pelas lideranças indígenas que haviam incluído no plano de saúde local a demanda pela reforma dos polos-base já no ano de 2007. Os profissionais da EMSI até promoveram ações de atenção primária em condições improvisadas nos espaços de escolas e centros sociais da comunidade de cada aldeia, durante o período da pesquisa de campo. Todavia, exigir-lhes pernoitar por longo período, em média vinte dias, em condições adversas, muito diferentes daquelas em que se sentiam preparados, seguros e acostumados, não era uma questão que figurava no horizonte moral ou mesmo contratual, pois haviam sido contratados para atuar nos polos-base. Nesse contexto, a atuação dos AISs foi central em alguns momentos. Houve um dia em que a AIS da aldeia Tartaruguinha trouxe uma gestante até o Polo-Base Kwatá para fazer a primeira consulta do pré-natal. Da mesma forma, os AISs das aldeias Niterói, Fronteira e Malocão trouxeram também gestantes para fazer o acompanhamento pré-natal no Polo-Base Kwatá.

Não disponho de dados secundários que permitam afirmar quantas consultas de pré-natal foram realizadas durante o período do trabalho de campo ou mesmo quantas consultas cada gestante fez. No entanto, minha intenção não era avaliar a qualidade dos serviços de atenção ao pré-natal, o que exigiria metodologia específica, fosse a comparação entre indicadores de ações programadas e ações realizadas, fosse a avaliação do próprio usuário.

A observação participante me permitiu atestar que as articulações entre as formas de atenção biomédica e as formas de atenção indígenas, sejam xamânicas, de autoatenção, religiosas ou outras, foram realizadas pelos próprios indígenas no interior das práticas de autoatenção (Scopel, Dias-Scopel G Wiik, 2012; Scopel, 
2013). Foi o caso das mulheres gestantes Munduruku que realizaram o pré-natal no polo-base da aldeia Kwatá e na rede do SUS municipal, que também consultaram os especialistas indígenas, os pajés e as parteiras, para "pegar barriga". Ou, então, as mulheres mais velhas da família extensa com reconhecida expertise sobre banhos, "pegar barriga", "puxar a mãe do corpo" e outros saberes centrais à condução de uma gestação e um parto saudáveis, como uma dieta alimentar adequada, esforços para saciar o desejo ou para não se entregar ao "abalo de criança". Ou ainda, a fabricação de dádivas ao feto para garantir disposição e sucesso nas atividades diárias. Enfim, as mulheres indígenas articularam uma diversidade de formas indígenas de atenção à saúde e, especialmente aquelas que moravam nas aldeias onde os polos-base estavam localizados, também recorreram à diversidade de práticas biomédicas que constituem o acompanhamento pré-natal. Isso mesmo diante das dificuldades encontradas pela EMSI para promover as ações de cobertura do pré-natal na TIKL e apesar da precarização da rede do SUS na cidade de Nova Olinda do Norte.

A participação das mulheres Munduruku nas ações biomédicas de acompanhamento pré-natal era estimulada por diversos atores, entre eles a equipe de saúde, os AISs e as lideranças indígenas. Esses diversos atores sociais estavam a todo momento em reuniões da associação indígena ou da equipe de saúde, em campanhas de vacinação ou em dias de consulta médica, relembrando às mulheres indígenas as diversas exigências do MS para que a família mantivesse o recurso do Bolsa Família, "programa federal de transferência direta de renda a famílias em situação de pobreza e vulnerabilidade social" (Brasil, 2012). O estímulo vinha como contrapartida obrigatória das famílias beneficiárias do programa. Esses mesmos atores destacavam, sobretudo, a importância do comparecimento nas consultas de acompanhamento e da realização dos exames de pré-natal, caso atestada a gravidez, e o monitoramento do crescimento e vacinação das crianças. Além dessas ações, cumpre destacar que as famílias inscritas no programa ainda deveriam cumprir a exigência de retorno de consulta após o parto. ${ }^{58}$ De fato, a enfermeira do Polo-Base Kwatá relatara na reunião da Organização dos Povos Indígenas Munduruku e Sateré, realizada nos dias 28 e 29 de maio de 2011, um aumento de $100 \%$ na realização do exame de prevenção do câncer do colo do útero. Ela atribuiu a realização de cem exames coletados em vinte dias a uma nova exigência feita pelo Programa Bolsa Família. E afirmou, em público, que antes ninguém se dirigia a ela para realizar o exame. Outro dado sobre o trabalho da EMSI apresentado naquela reunião pela enfermeira foi o acompanhamento de trinta das 39 gestantes cadastradas pelo Polo-Base Kwatá no SispreNatal. Segundo ela, as dificuldades de deslocamento ou a ausência das mulheres na aldeia em dia de consulta médica ou em campanha de vacinação contribuíram para que nove gestantes ficassem sem qualquer acompanhamento pré-natal. 
Embora o MS tenha registrado, em 2004, alguns obstáculos para o alcance de uma qualidade mínima nos serviços de atenção ao pré-natal prestados na rede do SUS, foi identificada também uma queda na taxa de mortalidade materna entre 1999 e 2001 (Brasil, 2004b: 27). O MS atribui essa queda, bem como a da mortalidade infantil, ao aumento de consultas do pré-natal, incluindo a realização dos exames e da imunização recomendados, a partir do ano de 1997 (Brasil, 2004b: 28). Infelizmente, ainda não existe uma avaliação semelhante que considere a população indígena no Brasil. No entanto, encontramos, no relatório final do Inquérito Nacional de Saúde e Nutrição dos Povos Indígenas (Coimbra Jr. et al., 2009), informações relevantes sobre as condições de saúde das mulheres e crianças indígenas no país e alguns dados sobre o acompanhamento pré-natal, levantados em 2008 e 2009. No relatório consta que

88,6\% das mulheres referiram ter realizado pelo menos uma consulta de pré-natal com médico ou enfermeiro durante a gravidez do filho vivo mais novo com idade inferior a 60 meses (...). Porém, há importantes diferenças entre as macrorregiões. Enquanto no Norte e no Nordeste $72,4 \%$ e $86,4 \%$ das mulheres realizaram pelo menos uma consulta, respectivamente, no Centro-Oeste $(94,3 \%)$ e Sul/Sudeste $(97,5 \%)$ essas proporções foram superiores a 94\%, sendo essa superioridade estatisticamente significativa em relação ao Norte e Nordeste. (Coimbra Jr. et al., 2009: 179)

Consta também no relatório a média do número de consultas ao pré-natal realizadas pelas mulheres indígenas, a qual não atinge o número mínimo de seis consultas estabelecido pelo Programa de Humanização do Parto e Nascimento (Brasil, 2000):

A média do número de consultas pré-natais relativas à gravidez do filho vivo mais novo com idade inferior a 60 meses foi de 4,7 consultas por mulher (IC 95\%: 4,4-5,0) para o conjunto das macrorregiões, inferior ao número de consultas preconizado por mulher pelo Ministério da Saúde (...). Essa média foi mais baixa no Norte $(3,1$; IC 95\%: 4,4-5,0) e mais elevada no Centro-Oeste $(4,7$; IC 95\%: 4,2-5,2), Nordeste (5,3; IC 95\%: 5,0-5,6) e Sul/Sudeste (5,3; IC 95\%: 4,7-5,8), com diferença estatisticamente significativa entre essas macrorregiões e o Norte. (Coimbra Jr. et al., 2009: 182)

Outra fonte de dados relevantes sobre a atenção biomédica ao pré-natal é o trabalho Sateré-Mawé: retrato de um povo indígena (2005), que apresenta um diagnóstico sociodemográfico das condições de vida dessa população no estado do Amazonas. ${ }^{59}$ Isso porque na TIKL há uma aldeia habitada por índios Sateré-Mawé, contemplados no levantamento realizado por esse trabalho, adstrita ao Polo-Base Laranjal. Interessa-me destacar aqui os dados relativos à percepção das indíge- 
nas sobre o programa de atenção ao pré-natal. Das 381 indígenas residentes nas diversas aldeias Sateré-Mawé que haviam tido filho nos últimos 12 meses, 240 relataram não ter recebido qualquer atendimento biomédico referente à gestação no ano de 2003. Isso dá um total de 63\% de residentes em áreas indígenas que passaram a gestação sem atenção prestada pelos serviços de atenção primária ao pré-natal. Das 141 mulheres Sateré-Mawé que realizaram o acompanhamento pré-natal, "apenas nove (6,3\% do total) receberam um número de consultas próximo àquele recomendado (...) pelas normas do programa de saúde da mulher" (Teixeira, 2005: 81).

Os autores concluem: "os resultados obtidos indicam uma insuficiente cobertura pré-natal" (Teixeira, 2005: 82). Essa mesma conclusão se repetiu, como veremos a seguir, no relatório do Inquérito Nacional de Saúde e Nutrição dos Povos Indígenas (Coimbra Jr. et al., 2009).

Entre os dados do relatório do Inquérito Nacional de Saúde e Nutrição dos Povos Indígenas, cabe sublinhar a elevada prevalência de anemia nas mulheres grávidas da macrorregião Norte: em torno de 44,8\%, de uma amostragem de 142 mulheres (Coimbra Jr. et al., 2009: 145). Recapitulo esses dados porque informam, de modo geral, sobre as condições de saúde das mulheres indígenas no Brasil e, principalmente, porque na macrorregião Norte, onde se encontram os Munduruku da TIKL, foram encontrados os piores índices seja de condições de saúde, seja de cobertura e qualidade dos serviços biomédicos ofertados, referentes ao Programa de Humanização do Parto e Nascimento (Brasil, 2000).

Embora eu não tenha realizado um levantamento estatístico nem epidemiológico, os dados que obtive na observação participante apontam para a mesma direção das conclusões do Inquérito Nacional de Saúde e Nutrição dos Povos Indígenas (Coimbra Jr. et al., 2009). Em especial no que se refere à baixa qualidade do serviço de atenção ao pré-natal ofertada às gestantes Munduruku. Isso, de certa forma, corrobora os resultados apresentados no relatório final daquele inquérito, no qual a macrorregião Norte apresentou as menores proporções de "pedidos de exames, variando de 2,2\% para sorologia para rubéola a 32,6\%, para teste sorológico para sífilis (VDRL)". Todavia, como vimos anteriormente, as gestantes Munduruku não estavam fazendo tais exames à época da pesquisa de campo porque a rede municipal do SUS não os estaria realizando. Em síntese, os dados da pesquisa de campo na TIKL corroboram as conclusões apresentadas naquele inquérito: "Tendo em vista as ações preconizadas pelo Ministério da Saúde para uma atenção pré-natal qualificada (Ministério da Saúde, 2005), os resultados ora apresentados evidenciam condições menos satisfatórias do pré-natal na macrorregião Norte" (Coimbra Jr. et al., 2009: 188).

Entretanto, os desafios para ampliar a cobertura e a qualidade do Programa de Humanização do Parto e Nascimento (Brasil, 2000) no contexto de que os Munduruku da TIKL fazem parte não se limitavam às ações promovidas pela EMSI, no 
âmbito da atenção primária, ofertada pelo DSEI-Manaus. Naquele contexto, a rede do SUS na cidade de Nova Olinda do Norte, no nível secundário, também apresentava sua parcela de responsabilidade pela baixa qualidade das ações relativas ao acompanhamento pré-natal.

Por fim, gostaria de salientar outra razão da expectativa das gestantes Munduruku por realizar o pré-natal no Polo-Base Kwatá. O programa de acompanhamento pré-natal foi destacado pelos indígenas e por profissionais da saúde da EMSI como um pré-requisito para o recebimento do auxílio-maternidade. Em certo sentido, compreendo os motivos pelos quais essa ideia se sustentava, pois para requerer o auxílio-maternidade é preciso apresentar alguns documentos, como o atestado médico original ou a certidão de nascimento da criança. Tendo em vista que muitos partos foram domiciliares, sem a presença de um profissional biomédico, parece plausível supor que a posse do Cartão da Gestante serviria como prova, ao menos, da gestação. Todavia, essa é uma questão que merecerá uma futura investigação, capaz de contemplar os meios pelos quais as mulheres Munduruku têm usufruído do auxílio-maternidade e as dificuldades para requerê-lo. De antemão, sei apenas que era preciso se deslocar até a cidade de Itacoatiara, situada à margem esquerda do rio Solimões, de posse de um documento fornecido pela Fundação Nacional do Índio (Funai).

Em 2013, apresentei esses dados para alunos do curso de Licenciatura Intercultural Indígena, na Universidade Federal de Santa Catarina. Esses alunos me ajudaram a refletir sobre minha pesquisa. Um dos participantes, que era AIS, comentou que as mulheres Xokleng não realizavam mais o parto domiciliar; todas estariam fazendo apenas o parto hospitalar, pois assim obteriam o documento, atestado médico, para requererem o auxílio-maternidade com maior agilidade. Ele estava nos dizendo que uma questão de ordem legal, de escopo jurídico, estava condicionando a escolha do local do parto.

Entre os Munduruku da TIKL, como veremos a seguir, essa questão não apareceu como um fator importante na decisão de realizar o parto hospitalar. Entretanto, cumpre esclarecer que foi durante o período do acompanhamento pré-natal que os profissionais da saúde observaram a necessidade do parto hospitalar. Dessa forma, o sistema de saúde tem incentivado e estimulado as mulheres Munduruku a parir nos hospitais da cidade. Isso resultou em uma situação controversa, na qual a ideologia da medicalização do parto e uma crescente demanda, por parte dos profissionais da saúde e dos indígenas, pelo parto hospitalar em determinadas situações coexistia com um contexto de acesso restrito a tecnologias obstétricas, que não provia sequer um simples exame de sorologia para detecção da sífilis. Nesse contexto de baixa qualidade e cobertura das ações de acompanhamento pré-natal, a questão da cidadania desponta como um desafio continuamente vivenciado pelas mulheres indígenas no acesso aos serviços de saúde. 
58 Para maiores informações, ver a portaria interministerial n. 2.509, de 18 nov. 2004, que "dispõe sobre as atribuições e normas para a oferta e o monitoramento das ações de saúde relativas ao cumprimento das condicionalidades das famílias beneficiárias do Programa". Disponível em: < http://dtr2001.saude.gov.br/sas/PORTARIAS/Port2004/Gm/2509.htm>. Acessado em: 20 dez. 2013.

59 Resultado da parceria de diversas instituições sediadas no Amazonas, entre elas a Universidade Federal do Amazonas (Ufam), a Fundação Estadual de Política Indigenista do Amazonas, a Fundação Joaquim Nabuco, a Coordenação das Organizações Indígenas da Amazônia Brasileira e a Secretaria de Educação do Estado do Amazonas, em trabalho financiado pelo Fundo das Nações Unidas para a Infância e Fundo de População das Nações Unidas, sob a coordenação de Pery Teixeira, da Ufam. 


\section{Práticas de Autoatenção Relativas ao Parto: pluralidade de sistemas médicos, articulação e autonomia relativa}

As práticas de autoatenção ao parto entre os Munduruku permitem enfatizar diferentes abordagens médicas sobre o ato de parir e também identificar diferentes formas de atenção às mães e aos pais gestantes. De modo semelhante ao que ocorre em outras partes do mundo, os saberes compartilhados entre os Munduruku sobre a fisiologia e a anatomia do parto diferem daqueles que embasam o modelo biomédico (Belaunde, 2005; Conklin G Morgan, 1996; Newman, 1972; Platt, 2002; Sesia, 1996). Apesar das diferenças de abordagem entre as formas biomédicas e as indígenas de atenção à gestação e ao parto, como vimos no capítulo anterior, as mulheres Munduruku as têm articulado em suas práticas de autoatenção realizadas ao longo da gestação, que incluem desde o uso de remédios caseiros, banhos, dietas alimentares e comportamentais, "pegar barriga", entre outros, até os serviços de atenção primária para controle do pré-natal.

Desde a ampliação da cobertura e do acesso aos serviços de saúde biomédicos, o parto hospitalar também se tornou um recurso considerado como opção pelas mulheres indígenas no Brasil. No contexto da Terra Indígena Kwatá-Laranjal (TIKL), em certa medida, a escolha do local apropriado para o parto - em casa, na aldeia, ou no hospital, na cidade - refletiu decisões tomadas a partir das interações com os diversos atores sociais intencionalmente contatados ao longo da gestação. Entre os Munduruku, as mulheres gestantes procuraram tanto profissionais da equipe biomédica quanto pajés, "parteiras" e, principalmente, as mulheres mais velhas da família extensa.

Apesar de o parto hospitalar ser um recurso biomédico recente no contexto da TIKL, seguramente já figura como um direito conquistado do qual não se quer abrir mão, ainda que repleto de controvérsias devido às especificidades das formas de atenção munduruku ao parto e ao pós-parto, as quais se defrontam com o contexto hospitalar e biomédico também de atenção ao parto e ao pós-parto. Todavia, muitas mulheres Munduruku optaram por parir em casa, na aldeia Kwatá, durante o período do trabalho de campo. Para as mulheres e os homens Munduruku, os cuidados com o parto antecedem o momento do trabalho de parto, do ato de parir. Assim, as causas de um parto bem-sucedido englobam o cumprimento das ações 
prescritas ou proibidas aos pais ao longo da gestação. Daí decorre que os riscos envolvidos em um trabalho de parto incluem os efeitos advindos do descumprimento dessas prescrições. Há, ainda, outras causas consideradas como variáveis de risco para o parto, como, por exemplo, faixa etária, pressão alta, infecções de malária e a posição do feto, as quais emergiram a partir do uso dos serviços biomédicos e implicaram mesmo a escolha do local do parto.

Se por um lado é inquestionável que o parto hospitalar constitui um recurso biomédico, por outro cumpre questionar que fatores interagem na escolha do local e do tipo de parto. Como veremos, no contexto de pluralidade de formas de atenção ao nascimento, as decisões foram tomadas no interior de relações sociais marcadas por poder. Isto é, a coexistência de diferentes saberes, infelizmente, não está isenta de assimetrias nas relações; ao contrário, os sujeitos, coletivos e individuais, justapõem os saberes, valorizando alguns em detrimento de outros. Assim, a autonomia do casal Munduruku na decisão sobre o local e o tipo de parto é relativa, pois tal processo é mediado pela interação com os profissionais de saúde da biomedicina e com outros indígenas contatados ao longo da gestação. As práticas de autoatenção relativas ao parto das mulheres Munduruku permitem destacar que os indígenas promovem a complementaridade e a articulação entre os diferentes saberes, indígenas e biomédicos, quando disponíveis.

\section{Atividades cotidianas que incidem sobre a qualidade do parto}

Em capítulo anterior, apresentei exemplos de práticas de autoatenção à gestação realizadas por mulheres e homens Munduruku para sintetizar a construção social do corpo do bebê, em que sobressaíram as relações afetivas no interior da família extensa e, principalmente, as interações maritais e dos pais com o bebê. Agora, quero destacar as práticas de autoatenção à gestação diretamente relacionadas ao parto. Do ponto de vista dos Munduruku, tanto a gestante como o pai da criança são responsáveis por facilitar ou dificultar o trabalho de parto. As atividades exercidas pelos pais ao longo da gestação, conforme apresento a seguir, foram orientadas visando ao momento do parto. O tempo e a dor envolvidos no ato de parir constituíram as expectativas que orientaram as motivações das práticas de autoatenção ao parto.

Era uma quarta-feira ensolarada de setembro de 2010 e o jovem casal Naná e Moacir se preparava para torrar farinha quando cheguei, por volta das 8 horas da manhã. Naná lavava a goma para tirar a "fortidão do tucupi" que estava em uma grande bacia verde de plástico no chão da casa de farinha ou rancho, e seu marido, Moacir, havia saído em busca de mais água à beira do rio, agora um 
pouco mais distante, pois na estação da vazante dos rios já apareciam longas faixas de terra, antes cobertas pelas águas do Canumã. Já havia mandioca umedecida e ralada colocada no tipiti para ser escorrida e logo misturada com a mandioca seca ralada para ser peneirada e, então, torrada no forno. Moacir, um homem jovem, de aproximadamente 25 anos, foi quem tirou o tipiti da vara onde estava pendurado e despejou a massa de mandioca úmida e ralada na canoa de uso próprio para o fabrico da farinha. Naná, com cerca de 25 anos também, passou a misturar e peneirar as mandiocas raladas. Moacir, assim que tirou a massa de mandioca do tipiti, imediatamente o encheu com uma nova leva de massa e foi ajudar Naná a peneirar. Ela me explicou que é nessa etapa que se separa a crueira, um amontoado de mandioca que não passa na peneira e serve para fazer mingau, depois de misturado com água ou leite, e para fazer "fritinho", se misturado com um pouco de farinha e água, e frita. Moacir já havia coletado e arrumado a lenha para fazer fogo no forno antes que eu chegasse. Pouco antes de terem uma quantidade suficiente de farinha peneirada para fazer a primeira fornada, ele acendeu o fogo, enquanto Naná continuou a atividade de peneirar. Com o fogo no ponto para torrar a farinha, ela preparou o tacho para iniciar a torra. Jogou um pouco de óleo e o espalhou com um pano por toda a superfície do tacho. Explicou-me que nesse momento era preciso ter cuidado e jogar somente um pouco de óleo, para evitar que pegasse fogo com o calor do tacho. Feito isso, Naná começou a jogar a farinha no tacho quente enquanto Moacir mexia de um lado para outro com um remo, também utilizado apenas para torrar a farinha. Depois disso, foram ainda quase três horas jogando farinha no tacho e retirando as porções que já estavam bem amarelas, torradas ao gosto do casal. Naquele dia eles torraram uma quantidade de quase "50 litros". Durante todo o tempo é preciso ficar mexendo a farinha para que ela torre uniformemente e não queime. Embora Moacir fosse o responsável por mexê-la, houve um momento em que Naná assumiu essa função para que seu esposo fosse buscar mais água e lenha. Ela assumiu a atividade de jogar e retirar a farinha do tacho, contando, em alguns momentos, com a ajuda dele para retirá-la e colocá-la na saca. Durante todo o trabalho, o casal esteve acompanhado de seu filho mais novo, Bimbo, de pouco mais de 1 ano de idade. Ele ficou por ali, distraindo-se com gravetos, comendo um pouco da farinha já torrada e tucumã com o auxílio de sua mãe, e chegou a dormir. A filha mais velha, de 3 anos, estava na casa dos tios de Moacir, que era próxima, e aparecia algumas vezes na casa de farinha para brincar.

De fato, Moacir e Naná estavam torrando farinha no rancho dos tios dele, que ficava, naquela época, a poucos metros da casa em direção à beira do rio. Naquele dia, a refeição foi um peixe frito que Naná havia trazido de casa, acompanhado com a farinha ainda quentinha, recém-saída do tacho. Naná também levou uma garrafa térmica de café preto já adoçado. 
Seis meses depois, na última semana de março de 2011, Naná e Moacir estavam terminando de construir sua própria casa de farinha/rancho, ao lado da roça que haviam plantado poucos meses antes, no início do ano. E Naná estava grávida de sete meses. Em certa medida, a construção do primeiro rancho dessa família elementar consolidava a maturidade da relação marital do jovem casal, agora à espera do terceiro filho. Outras duas famílias elementares, de casais já maduros dessa família extensa e segmento residencial - uma delas com dez filhos - também estavam (re)construindo seus ranchos/casas de farinha. Todos contavam com incentivos do governo estadual, desde financeiros a insumos (inclusive o tacho), para a construção do novo rancho. Todavia, esse incentivo não era suficiente para um jovem casal construir seu próprio rancho. Outros casais jovens dessa família extensa continuavam utilizando o rancho dos pais da esposa. Até aquele momento, Naná e Moacir utilizavam o rancho da tia dele, pois os pais de ambos não moravam na aldeia. No entanto, em 2011, ao construírem seu próprio rancho para torrar a farinha, a posição social do jovem casal mudaria perante os demais membros da família extensa.

De fato, Moacir estava finalizando a cobertura de palha da casa de farinha e contou com a ajuda de Jô, marido de sua tia Ivana, para tecer o jacaré (cumeeira feita com palha) posto na base do telhado. Naquele momento não dei a devida importância ao fato de Moacir solicitar ao tio que tecesse o jacaré. Ingenuamente, interpretei o fato como consequência da falta de habilidade do jovem rapaz.

Figura 23 - Jacaré, artefato de palha trançada utilizado como cumeeira

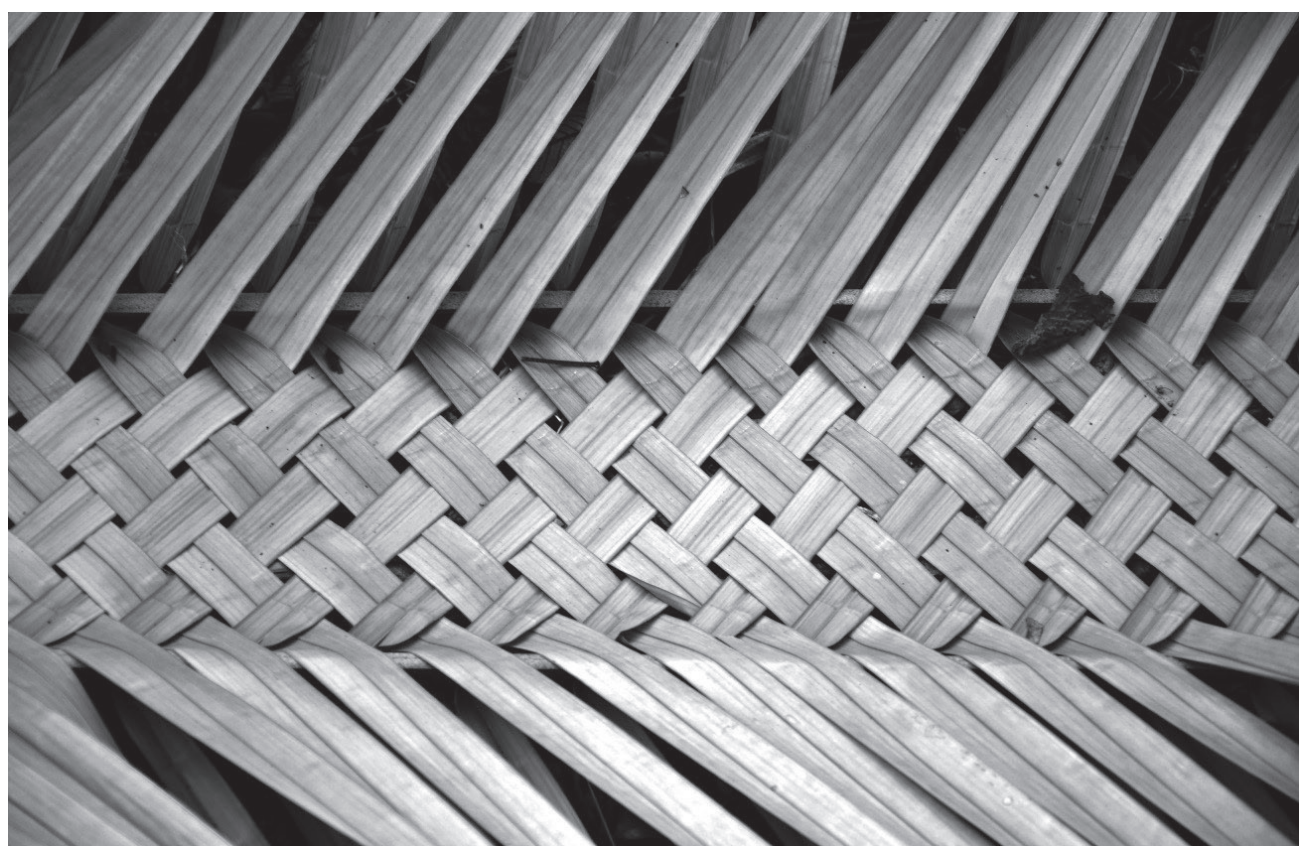

Foto Daniel Scopel. 
Só dois meses depois fui compreender o motivo para isso. Ivana, tia de Moacir, comentou que não era adequado mulher tecer ou fazer crochê durante a gestação porque o cordão umbilical poderia se enrolar no pescoço do bebê, o que dificultaria o parto. Ela contou isso durante uma conversa com Ceci, avó de Moacir, denunciando a atitude da irmã Iara, filha de criação de Ceci, que mesmo grávida de sete meses teceu o novo jacaré para colocar no telhado de casa naquela semana. Ivana afirmou que Iara deveria ter pedido ao cunhado, Jô, tio de Moacir, para tecê-lo.

Quando Jô teceu o jacaré para Moacir, Naná estava grávida de sete meses. Não posso afirmar que o motivo pelo qual seu tio teceu o jacaré tenha sido o mesmo comentado por Ivana ao recriminar sua irmã Iara. Todavia, não há razão para desconsiderar a possibilidade de que as ações do pai afetem diretamente as características físicas e morais de seus futuros filhos, conforme sugerido em capítulo anterior. E, ao que parece, as interferências decorrentes das atividades exercidas pelo marido/pai também têm impactos no momento do trabalho de parto. Logo, podemos inferir que Moacir não tenha tecido o jacaré para evitar que o cordão umbilical se enrolasse no pescoço do bebê, criando dificuldades ao parto da esposa. Assim, a motivação do marido/pai para não tecer estaria orientada pela expectativa da qualidade do parto de sua esposa. Aliás, Moacir e Naná já haviam passado pela experiência de ver a filha mais velha sofrer as consequências da quebra de um tabu por parte do pai durante a gestação. Moacir matara uma cobra na roça e Jacy nasceu com o corpo muito mole, tanto que aprendeu a engatinhar de barriga, como se rastejasse. Somente após "baterem" com a ponta do tipiti novo na nuca da menina é que seu corpo passou a ter força, ser mais firme, e ela passou, então, a engatinhar. A ação do pai afetou a formação do bebê ainda no ventre da mãe, e as consequências se fizeram sentir após o nascimento e só foram revertidas com a terapêutica adequada; caso contrário, talvez Jacy sequer tivesse aprendido a andar. Em termos pragmáticos, não havia motivos para arriscar. Embora o parto seja interpretado como um processo saudável, existem alguns riscos que os Munduruku intencionam controlar, visando a garantir um parto eficaz, isto é, que resulte de forma rápida, sem prejuízos para a mãe e o bebê.

\section{O parto domiciliar}

Além da construção da casa de farinha, Moacir e Naná também estavam trabalhando na roça durante aquela semana de março de 2011. Naná, ao final do sétimo mês de gestação, estava replantando algumas manivas. Apenas um dia observei que ela contava com o auxílio da tia e do primo de Moacir para replantar. De fato, eu a vi seguir com as atividades diárias de trabalho até dois dias antes do parto. Ela trabalhou na roça, capinando; carregou sobre a cabeça baldes com roupas 
para lavar no rio, trazendo-as de volta para estender no terreno da casa; deu banho no filho mais novo, com pouco mais de 2 anos, que ainda não sabia se banhar e estava começando a aprender a nadar; auxiliava também sua filha mais velha, à época com 4 anos, na hora do banho; carregava sobre a cabeça baldes com louças e panelas da casa para lavá-las também no rio, além de cozinhar e cuidar da casa.

Naná pariu em casa no dia 4 de maio, uma quarta-feira, às 7 horas da manhã. Onze dias após o parto, ela ainda permanecia a maior parte do tempo dentro de casa, e seus afazeres diários eram cuidar do bebê recém-nascido, amamentá-lo, banhá-lo e cuidar dos outros filhos. Raramente saía de casa, e quando o fazia, permanecia no terreno ao redor da casa. Fui visitá-la 11 dias após o parto e pedi que me contasse como havia sido. Estávamos na sala da casa, sentadas no chão. O bebê estava dormindo na rede, no quarto da família, e sua filha mais velha nos acompanhava. O marido havia ido pescar, levando consigo o menino. Ela me contou:

Estava sentindo dor desde domingo de madrugada, desde segunda-feira, ainda fomos arrancar mandioca, só que eu não falei nada pro Moacir [marido] não, só eu mesmo. Diz que quando a gente sente dor, logo a gente avisar o pai, diz que a gente sofre mais, diz que o filho fica... [breve pausa], diz que fica dengoso, fica tolo, diz que custa a nascer. Aí demora mais. Avisei já quando não aguentei mais. Passou segunda, terça. Terça à noite foi que apertou a dor, lá pra madrugada já, eu não estava mais aguentando a dor. Se tivesse nascido à noite, tinha tido ele aí só eu e o Moacir [risos]. Eu falei pra ele de madrugada. Ele ficou aí, foi ver o pessoal, Araci, estavam tudo dormindo. Foi 6 horas da manhã eu mandei chamar a Araci, mandei chamar a Araci pra pegar minha barriga que estava muito doído. Ele foi pegar a parteira lá pro Cajual. Aí a dona Araci mandou a Mari chamar o José [técnico de enfermagem que estava no polo-base]. Só o José chegar, ele nasceu. Ele nasceu às 7 horas da manhã, na quarta. Nasceu rapidinho, agora a placenta custou. O resto dele nasceu só às 9 horas, já estava preocupada. O Moacir que enterrou a placenta, não sei nem pra onde. Quando tá direito não custa a nascer, não. Nasceu com três quilos e trezentos, [é provável que o técnico de enfermagem o tenha pesado]. (Naná, narrativa gravada no dia 14 de maio de 2011)60

A dor é uma sensação muito mencionada na fala das mulheres Munduruku sobre o ato de parir. Não é tanto a intensidade da dor que focalizam, mas a atitude da mulher diante da dor do parto. Araci, esposa de Itamar, mãe de 13 filhos, que sabia "pegar barriga" e "puxar a mãe do corpo", isto é, dominava os saberes relativos à gestação e ao parto, com experiência em partejar, também assinalou o comportamento da mulher diante da dor do parto como um fator que podia facilitar ou dificultar o tempo que o bebê levaria para nascer. As mulheres Munduruku que relataram suas experiências enfatizaram a importância de aguentar sozinhas a dor. De certo modo, não dizer que está sentindo dor e aguentar em silêncio até o momento do trabalho de parto era um valor e uma prática para aquelas mulhe- 
res. Um valor que demonstrava sua força e constituía uma prática de autoatenção ao parto, diretamente voltada para o fim pragmático do nascimento, da expulsão do bebê. Conforme explicou Lara, outra indígena que pariu todos os seis filhos na aldeia, é importante a mulher esperar o momento certo de avisar o marido sobre a dor, "porque diz que isso pode dificultar tudo na hora do parto". ${ }^{61}$

Entre os Munduruku, o parto é, primeiramente, um acontecimento do âmbito familiar, do foro íntimo da família elementar, do qual participam as mulheres mais velhas da família extensa que têm experiência de "pegar barriga", isto é, de partejar. Conforme os relatos de jovens e velhas mulheres Munduruku sobre experiências de parto, os maridos, quando presentes, participavam ativamente na hora do parto, seja chamando as mulheres expertas em partejar ou buscando aquelas identificadas como "parteiras", seja segurando a esposa no momento da expulsão, levando água ou cortando lenha.

Na família extensa e no segmento residencial em que morei, das sete mulheres que pariram durante o período do trabalho de campo, quatro fizeram o parto em casa, na aldeia. Todas mandaram chamar Araci para auxiliar no parto. Em alguns casos também chamaram uma "parteira". Araci era uma das mulheres mais velhas daquela família extensa e tinha "o dom de puxar a mãe do corpo" e de "pegar barriga", práticas centrais nas formas de atenção indígena munduruku ao parto. Detalharei essas práticas adiante. Por ora, pretendo esclarecer as dificuldades que encontrei em campo para situar a categoria "parteira", um dos recursos utilizados pelas mulheres Munduruku nas práticas de autoatenção ao parto feito em casa, na aldeia.

\section{Atuação das mulheres da família extensa e das "parteiras" no parto domiciliar}

Quando perguntei aos agentes indígenas de saúde (AISs) e aos homens e mulheres da aldeia Kwatá quem eram as parteiras, Araci não foi identificada como tal. Aliás, ela própria sequer se identificou como parteira, apesar de ser uma interlocutora com quem conversei todos os dias durante o trabalho de campo e com quem participei em inúmeras atividades de lazer e trabalho. O resultado que obtive com minha pergunta foi a indicação de cinco mulheres. Duas delas confirmaram que eram parteiras e que haviam feito um curso oferecido pela Fundação Nacional de Saúde (Funasa) muitos anos antes. As outras três também foram citadas como parteiras que teriam feito o mesmo curso. 62

Nas visitas a outras aldeias da TIKL, encontrei também "parteiras" que haviam participado desse curso "na época da Funasa", as quais se lembravam de temas centrais como a questão da higiene na hora do parto, os cuidados com o mate- 
rial para cortar o cordão umbilical e para assear a mãe. Não obtive informações mais precisas sobre onde ou quando o curso fora realizado, quem o ministrara e se fora exclusivo ou não para os indígenas da TIKL. Todavia, o tema do curso foi lembrado pelas "parteiras" com quem conversei. Aliás, algumas delas pareciam fazer uma analogia entre as instruções de assepsia biomédica e as práticas de cuidado com os panos de sangue do parto, lembrando a importância de não os lavar à beira do rio, como uma prática de higiene relativa ao parto, pois isso poderia atrair os botos malignos. Adiante, veremos outra justificativa pragmática para essa prática em que o sangue aparece como mediador da perigosa relação entre humanos e não humanos, segundo a cosmografia munduruku.

A "parteira" Gioconda morava na parte central da aldeia Kwatá e era popular, mesmo afirmando que já não fazia mais partos, pois estava velha demais para isso. Segundo ela, já lhe faltavam a agilidade e a força necessárias para pegar a criança e os problemas de visão advindos da catarata dificultavam seu trabalho. 63 Todavia, lembrou que havia partejado "um bocado até entrar o polo-base". Apesar do ingresso dos profissionais da saúde no interior da aldeia para prestar atenção primária, lembrou que poucos dias antes, naquele ano de 2011, a enfermeira a havia chamado para fazer um parto. Gioconda alertou-a que não fazia parto há muito tempo, mas ao se sentir encorajada pela própria enfermeira o fez, cortando o umbigo e cuidando da criança. A enfermeira cuidou da parturiente, que teve bebê em março de 2011. Gioconda é popular como "parteira" não porque fez um curso para tal, mas porque é reconhecida por ter "o dom". As outras quatro "parteiras" citadas pelos indígenas também eram reconhecidas por terem o dom de partejar.

Ao conversar com Araci, que tem mais de 60 anos de idade, e com outras sete mulheres de diferentes famílias extensas, todas com mais de 40 anos, cujos partos foram feitos em casa, na aldeia, ficou evidente a participação das mulheres mais velhas da família extensa, às vezes mães, avós, sogras ou cunhadas da parturiente na hora do parto. Embora essas mulheres pudessem ter suas práticas legitimadas pelo dom, suas falas evidenciavam que seus espaços de atuação eram limitados ao interior da família extensa. Exatamente o oposto da atuação das parteiras nomeadas por diferentes indígenas da aldeia Kwatá e que fizeram um curso para parteiras "na época da Funasa". Essas "parteiras" atuavam transitando entre diferentes famílias extensas. Foi o caso do parto feito por Gioconda junto com a enfermeira do polo-base, mencionado acima, no início de 2011. Vemos também o trânsito das "parteiras" no parto relatado por Naná, que mandou chamar, além de Araci, uma parteira que, por morar em uma parte distante da aldeia Kwatá, chamada Cajual, não chegou a tempo para fazer o parto.

Araci contou-me em detalhes como fora o parto de Naná três dias após o ocorrido, enquanto estávamos na cozinha de Ceci, junto com Iara, que também auxiliou na hora do parto. Ceci é a avó de Moacir e Iara, sua tia. Perguntei quem havia ajudado a Naná: 
Eu, a Iara, Rita e o José, o rapaz, o técnico de enfermagem do polo-base. Aí, quando ela tava agoniada, né, nós ajudando ela, né? Aí a gente viu que não ia descer a criança, assim, de cócoras como ela queria ter, né? Aí, mesmo, acho que ela tava nervosa também, atacou um nervoso nas pernas dela, que ela ficou assim [Araci balança as pernas como se estivesse tremendo]. Não sei se é porque ela não tinha se alimentado bem antes, né? Aí, nós fizemos a cama e colocamos ela. Aí, ela se deitou. Aí, veio logo depois. Até que a criança veio rapidinho, não custou não. Agora, como eu tô dizendo, o que custou foi a placenta que ela teve 7 horas [o bebê], foi ter 9 horas [a placenta]. Aí, a gente ajeitou, ajeitou, ajeitou [talvez estivesse fazendo referência a massagens abdominais]. Aí, tem uma planta aqui que a senhora conhece, cubiu, né? Uma planta assim que dá uma fruta que a gente faz doce. Ali em casa tem, com uma folha larga [complementa Ceci]. Aí, essa folha aí, a gente pega a folha, a gente pila ela, tira assim dois dedos de sumo, do sumo dela, a gente pega põe uma pitadinha de sal e amônia e dá pra pessoa beber. Aí, eu peguei e dei pra ela, né? Dei duas vezes pra ela, né? Aí, eu olhava no relógio e dizia: ai, ai, ai, Senhor, nada de descer! Aí, eu lembrei a oração da Santa Margarida. Aí, eu fiquei atrás das costas dela. Aí eu fui falando: vou falar uma oração e quero que tu fale comigo, eu disse pra ela. Aí eu falava: Santa Margaria, Santa Margaria... daí, eu ia dizendo, daí, ela ia falando. Eu rezei três vezes atrás das costas dela. Foi terminando a oração e aquilo foi arriando. Ela teve rapidinho.

Ceci interveio e disse para Araci:

- Fala as palavras!

Perguntei se ela podia falar. Araci respondeu que sim, riu e pronunciou a oração de Santa Margaria:

Santa Margaria, Santa Margarida, não tô prenha nem parida Tirai essa carne podre de dentro da minha barriga Santa Margaria, Santa Margarida, não tô prenha nem parida Tirai essa carne podre de dentro da minha barriga.

Araci contou que após arriar a placenta, foi José, o técnico de enfermagem, que "asseou ela, né? Tudo direitinho". Depois disso, Naná foi para a rede, o técnico pediu que preparassem um copo de leite para ela e foi embora. Perguntei se haviam feito mais alguma coisa para a Naná e Araci falou que "puxou a mãe do corpo" dela:

Eu puxei, eu puxei porque quando nasce, a mãe do corpo tá fora do lugar. Aí, a gente tem que ajuntar, ajeitar. Puxa dos braços, das costas, tudinho. Dos braços puxa pra cima. Puxa, balança a barriga, faz assim com a mão [demonstra nela mesma, como se estivesse fazendo uma massagem e ajeitando algo logo abaixo do umbigo] e sente a palpitação. Tem que fazer isso pra mulher não ficar assim com aquela cólica. 
Na hora do parto da Naná, uma mulher ficou por trás, com os braços ao redor da cintura dela. Maria disse que ela tinha um "puxo comprido". Perguntei o que era isso e Araci e Ceci explicaram:

Araci. Isso é a dor pra descer a criança. Quando vinha a dor, né, ela botava a roupa do filhinho dela na boca e ela mordia, né? Quando dá a dor pra nascer a criança, a gente ajuda também, ajuda pouco, mas ajuda a criança.

Ceci. A dor dá, passa e depois volta e demora mais e dói mais, assim vai até dar aquela dor de nascer a criança. Aí, desce aquela secreção, já é da criança, aí, quando vem o puxo, a gente faz força junto. Aí para aquela dor. Aí, quando vem de novo aquela dor, a gente faz força. Porque tem pausa, né? Aí, quando vem de novo, que a criança já tá perto de nascer, aí que vem mesmo, toda hora aquela dor. Aí, a gente ajuda, aí, quando ele para, a gente para também.

Apresentei essas falas porque sintetizam elementos presentes em diversos relatos que obtive sobre experiências de parto em casa, na aldeia, os quais permitem delinear um modelo de atenção munduruku ao parto em casa. Segundo propõe Menéndez (2009), o modelo é sempre uma abstração construída pelo pesquisador. Nesse sentido, o modelo de atenção ao parto que apresento deve ser lido como um esforço analítico produzido com base na fala das mulheres indígenas sobre suas experiências de parir ou de partejar. Ao todo, foram 22 mulheres que relataram suas experiências, sendo que algumas falaram sobre mais de um parto.

Entre os Munduruku, o parto é feito em interação entre a parturiente e as mulheres que a auxiliam. Não houve nenhum caso relatado de mulheres que tenham parido sozinhas, como descrito em outros grupos indígenas (Langdon, 2013; Pérez-Gil, 2007a). As experiências relatadas indicam uma diversidade de posições no ato: de joelhos, com as mãos apoiadas na rede; parcialmente deitada ou sentada no chão, com alguém segurando pelas costas com os braços ao redor da parturiente; ou "sentada" em um banquinho (um banco de altura pequena, talvez $10 \mathrm{~cm}$ ), usado especialmente para o parto, com alguém apoiando pelas costas (Scopel, Dias-Scopel G Wiik, 2012). Esta última postura - sentada em um banquinho, quase de cócoras - era a preferida entre as mulheres Munduruku, dada a pequena distância entre a mulher e o chão.

Entre os Munduruku, o parto não aparece como um evento cercado por cerimônias; implica apenas a quebra da rotina cotidiana para a família elementar, sem impacto no andamento diário dos demais membros da família extensa, embora algumas pessoas sejam mobilizadas durante o trabalho de parto. Como visto aqui, mulheres com mais de 40 anos que pariram na aldeia contaram com o auxílio das mulheres mais velhas da família extensa. Eventualmente, em casos de complicações, algumas mulheres relataram a participação do pajé. ${ }^{64}$ Cumpre esclarecer que entre os Munduruku da TIKL encontramos tanto homens quanto mulheres, ainda em idade 
fértil, atuando como pajés (Scopel, Dias-Scopel G Wiik, 2012; Scopel, 2013). As parteiras que transitam por entre diversas famílias extensas podem ser vistas como um recurso recente, resultado talvez da interação com os serviços biomédicos. 65

\section{A atuação da Equipe Multiprofissional de Saúde Indígena no parto domiciliar em um contexto de pluralidade de formas de atenção}

Não posso deixar de mencionar a atuação dos técnicos de enfermagem, da enfermeira e do médico que, em determinados momentos, participaram na realização de partos na aldeia, sempre junto com outras mulheres, isso durante o tempo de minha pesquisa de campo.

Nesse modelo de atenção ao parto, quero sublinhar a participação de diversos atores de diferentes formas de atenção à saúde e às enfermidades a partir de decisões tomadas pela própria mulher parturiente e seu marido. Além das mulheres mais velhas da família extensa, as "parteiras", as profissionais da saúde e os pajés também podem ser chamados pelo casal. Todavia, estamos falando do contexto de uma aldeia que dispõe de um polo-base, uma unidade de atendimento primário à saúde e conta com a presença de profissionais que estão sempre se revezando em escalas de trabalho. Por esse motivo, Lara contou com a participação do marido, que a segurou pelas costas, da "parteira" Gioconda e do médico no nascimento do sexto filho, na noite de 15 de novembro de 2011, em casa, na aldeia Kwatá. No terceiro dia após o parto, Lara permanecia dentro de casa e decidi visitá-la, após notar que outras mulheres da família extensa estavam fazendo o mesmo. Lara contou que a "parteira", além de preparar o banquinho para o trabalho com muitos panos em volta e por cima, o fez com a ajuda do médico. Após o parto, o médico a asseou e foi embora. A "parteira" "puxou a mãe do corpo" e permaneceu na casa de Lara até domingo, auxiliando-a nos afazeres da casa. Lara sentiu-se reconfortada com a presença do médico justamente porque o bebê havia nascido com o cordão umbilical enrolado no pescoço e na cabeça.

Nas demais aldeias, a presença da equipe biomédica é esporádica, e em geral são os indígenas que se deslocam até o polo-base, e não a equipe de saúde até a aldeia. Embora façam visitas periódicas para campanhas de vacinação e atendimento médico, na maior parte do tempo os AISs são os únicos membros da equipe de saúde presentes nas aldeias (Scopel, 2013). Nelas, as mulheres que decidem parir em casa são auxiliadas por outras mulheres mais velhas de sua família extensa, podendo ou não contar com uma "parteira" ou pajé. Aliás, a participação de "parteiras", até mesmo na aldeia Kwatá, embora requisitada, nem sempre ocor- 
ria, dada a distância da casa da parturiente e da "parteira". Mas isso não foi um problema para os Munduruku, pois, conforme dito anteriormente, o parto é, antes de tudo, um acontecimento do âmbito familiar, de foro íntimo da família elementar, do qual as mulheres mais velhas da família extensa são chamadas a participar. No caso apresentado, inclusive, a mulher chamada para auxiliar no parto das jovens de sua família extensa era experiente na realização de partos e em determinadas práticas xamânicas, como rezas e ervas, específicas para facilitar o trabalho de parto. As "parteiras" e os pajés apareceram nos relatos das mulheres Munduruku como coadjuvantes dessas mulheres mais velhas somente nos casos de complicação na hora do trabalho de parto.

\section{Cosmografia e parto: a importância da "mãe do corpo" nos cuidados com o parto}

De certo modo, "pegar barriga" e "puxar a mãe do corpo", práticas centrais nas formas de atenção munduruku ao parto, são conhecimentos que não se concentram nas mãos de especialistas. Embora entre os Munduruku os pajés possam prestar auxílio à mulher gestante, assim como as "parteiras", muitas outras mulheres, com idade acima de 50 anos, sabiam "pegar barriga" para identificar a situação do feto, a sua posição e ajeitá-lo no "nascedouro" da mulher. Como vimos no capítulo anterior, a identificação do sexo do bebê é feita a partir das interpretações que as mães fazem sobre os movimentos fetais, mas também a partir das intervenções executadas por uma mulher que sabe "pegar barriga". De modo semelhante ao que Platt (2002: 127) encontrou entre os Macha, grupo falante de quéchua, na Bolívia, sugiro que, entre os Munduruku, as mulheres que também sabem "pegar barriga", as quais podem ou não ser parteiras, têm habilidades de apalpar e manusear o ventre materno, reposicionando uma imagem cultural do feto dentro do corpo da mãe.66

Do mesmo modo, os saberes relativos à "mãe do corpo" estão horizontalmente distribuídos entre homens e mulheres Munduruku. Durante a segunda etapa da pesquisa de campo, quando Naná ainda não estava grávida, conversamos sobre a "mãe do corpo". No dia 10 de novembro de 2010, após o almoço, vi que Naná estava na casa de Rita e decidi ir lá passar aquelas horas de muito calor à sombra da varanda da casa. Naná comentou que havia ido "pegar a mãe do corpo". Ela tocou seu umbigo e me mostrou que a "mãe do corpo" ficava bem abaixo dele. Afirmou que a mulher fica doente quando a "mãe do corpo" se espalha pelo corpo. Ivana já havia me falado que somente as mulheres têm "mãe do corpo".

Foi muito comum ouvir as mulheres falarem sobre a "mãe do corpo", pois saber se ela estava ou não no lugar constitui uma das primeiras práticas de 
autoatenção das mulheres Munduruku na vida adulta (Scopel, Dias-Scopel G Wiik, 2012). Ao sinal de qualquer mal-estar - dor de cabeça, febre, enjoo, dor abdominal ou cólica - a primeira ação das mulheres Munduruku é "puxar a mãe do corpo". Em geral, fazem também uso de remédio caseiro, como chás. Todavia, o deslocamento da "mãe do corpo" é nitidamente uma preocupação na vida das mulheres adultas Munduruku, e as medidas necessárias para o realojamento são uma das primeiras práticas de autoatenção.

Certa vez, durante a segunda etapa da pesquisa de campo, comentei que estava com mal-estar, enjoada e com a sensação de estômago pesado, como se não estivesse conseguindo fazer a digestão. Iara me recomendou que fosse ver Araci para ela "puxar a minha mãe do corpo", pois o que eu estava sentindo poderia ser sinal de seu deslocamento. Fui, então, até a casa de Araci, contei-lhe o que sentia e disse que Iara sugeriu que eu a procurasse para examinar a minha "mãe do corpo". Araci me levou até o seu quarto, orientou-me a deitar na cama e solicitou que eu abaixasse um pouco a bermuda e levantasse a blusa. Pediu à sua filha, que estava ali observando tudo, para alcançar um óleo. Ela trouxe um óleo corporal, desses produtos estéticos comprados no supermercado ou na farmácia. Araci passou o óleo nas mãos, pingou algumas gotas sobre minha barriga e passou a massagear com seus dedos toda essa área, fazendo uma leve pressão na região entre o umbigo e a pélvis. Massageou e apalpou por alguns minutos, não mais que dez minutos, e concluiu que minha "mãe do corpo" estava no lugar. Indicou-me um chá para ajudar na digestão.

A "mãe do corpo" é uma força importante para a saúde da mulher Munduruku no dia a dia, e foram especialmente as práticas de autoatenção ao parto que me fizeram notar sua centralidade na vida dessas mulheres. "Puxar a mãe do corpo" é fundamental para realizar um bom parto. Na hora do parto é preciso estar atenta para fatos não previstos, mas que podem alterar uma situação inicialmente normal e saudável, como, por exemplo, a "mãe do corpo nascer antes da criança", ou seja, sair do corpo da mulher. Conforme explicou Araci, que já havia visto isso acontecer, "é perigoso, a mulher pode morrer". Ela estava costurando enquanto me relatava as experiências de parto dos seus 13 filhos e "outros partos que vi", como ela própria disse. Naquele momento seu marido Itamar chegou e participou da conversa, tentando fazer-me entender o que era a "mãe do corpo". Eu perguntava se era o útero, ou a placenta, e a resposta, nos dois casos, era negativa. Itamar explicou que "a mãe do corpo é uma espécie de saúde da mulher. Se sai antes da criança, a mãe pode morrer". Araci explicou que durante a gravidez, conforme a criança vai crescendo, "a mãe do corpo vai descendo". É parte das práticas de autoatenção no parto "agasalhar a mãe do corpo", isto é, colocá-la de volta no lugar após o parto. Do contrário, a mulher sofrerá problemas de saúde, desde mal-estares leves, como cólicas, até casos mais sérios, que podem levar à morte. 
Em outro momento, Araci compartilhou com mais detalhes seus saberes sobre a "mãe do corpo". Confirmou que esta se localiza abaixo do umbigo. Afirmou que toda mulher a tem e que febre e dor são sinais de que a "mãe do corpo saiu do lugar". Quando a "mãe do corpo" sai do lugar, "entra embaixo da costela, do estômago", e isso causa "diarreia, febre, dor de cabeça, dor no corpo". A mãe do corpo costuma se deslocar mais quando a mulher não se alimenta bem e quando "entra vento embaixo da gente". Para saber se a "mãe do corpo" está no lugar é preciso puxar todo o corpo, inclusive os dedos, até estalar. Se não estalar, é sinal de que está fora do lugar. É por meio de massagens que se coloca a "mãe do corpo" novamente em seu lugar e também se confirma sua localização. Filó, matriarca de outra família extensa na aldeia Kwatá, explicou que a "mãe do corpo" era a força da mulher.67

Outras práticas de autoatenção relativas ao parto são os banhos. Eu mesma tomei banhos preparados por Araci para facilitar o meu trabalho de parto. O propósito dos banhos é abreviar o tempo do trabalho de parto, ou, como disse Araci, "para não custar a ter filho, para nascer logo". O banho consistia em um preparado de folhas classificadas como lisas e oleosas, entre as quais, graviola, "ariticum" e cacau. Essas folhas são maceradas, quebradas em alguns pedaços, misturadas com água e deixadas ao sol para esquentar. Araci aconselhou-me a tomar o banho dentro de casa após banhar-me no rio, dizendo que eu poderia beber um pouco daquela água. Note-se que o banho não se confunde com a limpeza higiênica diária do banho no rio ou na cacimba. Fiz exatamente como ela me havia aconselhado: após me lavar no rio, ainda na parte da manhã, subi para casa, peguei a bacia de metal onde estava meu banho, levei-a para o quarto e, com o auxílio de um caneco, joguei a água do banho sobre minha cabeça e meu peito, deixando que escorresse sobre minha barriga. Fiz apenas dois banhos.

No entanto, as mulheres Munduruku relataram fazer muitos banhos ao longo da gestação, de três a quatro vezes, sobretudo no último trimestre. Os banhos feitos para os partos atendiam ainda a outros objetivos com vistas a contribuir para o posicionamento correto das crianças, isto é, com a cabeça encaixada no "nascedouro" da mulher. Ceci, uma senhora de 92 anos, lembrou que seu primeiro parto foi muito difícil e que foi preciso chamar o pajé, pois a criança custou a nascer porque "estava de pé". O pajé a benzeu e a criança nasceu pelo braço. Após o parto, ele ensinou-lhe um banho para fazer durante as gestações seguintes para prevenir que seus futuros filhos nascessem de pé e assim facilitar o parto e ela sentir menos dor. Nesse caso, a água do banho devia ser jogada sobre a barriga com a ponta de uma flecha virada para baixo, a qual deveria ser jogada na direção "onde nasce o sol", após o último banho. Ceci conta que fez três vezes o banho e todos os seus outros 11 filhos nasceram "pela cabeça". Foi citado também o banho com tipiti novo "pra não custar a ter filho", conforme relatou Iza, uma senhora experiente em partejar mulheres jovens de sua família extensa. Araci também disse 
que banho de tipiti novo ajuda na hora do parto, pois "nada segura ele [o bebê]" na hora de nascer e também "para não sentir muita dor, pra nascer logo". Embora os banhos possam ser feitos com diversas folhas ou apenas com água jogada sobre o corpo com objetos específicos (tipiti ou flecha), o que constitui sua unidade é o uso de modo preventivo com o objetivo de facilitar o trabalho de parto, em que se destaca a busca pela brevidade e pela diminuição da dor.

Conforme dito anteriormente, "pegar barriga", "puxar a mãe do corpo" e preparar banhos não são saberes que se concentravam nas mãos de especialistas entre os Munduruku da TIKL (Scopel, Dias-Scopel G Wiik, 2012; Scopel, 2013). Além das "parteiras" e pajés, as mulheres mais velhas da família extensa também realizavam partos na aldeia Kwatá. Aliás, a participação das mulheres mais velhas da família extensa, fossem mães, sogras ou cunhadas da parturiente, apareceu com mais frequência não só no período do trabalho de campo, mas também nos relatos sobre experiências passadas. A atuação dos pajés apareceu exclusivamente em situações de complicação na hora do parto ou durante a gestação, quando eram procurados para "pegar barriga". Portanto, muitas mulheres já partejaram e, em alguns casos, o fizeram sem ter o saber adquirido pelo dom e muito menos em um curso de capacitação. A partir dos relatos, podemos dizer que a parteira é aquela que preparava o local adequado para o trabalho de parto, "pegava criança", cortava o cordão umbilical e "puxava a mãe do corpo". E que sua área de atuação se restringia ao interior da família extensa. Não ignoro, contudo, que algumas mulheres fossem reconhecidas por terem o dom de partejar e, por isso, pudessem circular entre as famílias extensas, auxiliando-as. Todavia, seria um equívoco supor que os saberes necessários para partejar constituíssem categorias de mulheres ou homens especializados. Por esse motivo, apenas parcialmente, e muito superficialmente, a "parteira" Munduruku pode ser caracterizada como especialista ou pessoa detentora de saberes esotéricos, mesmo que algumas mulheres tenham legitimidade social para atuar em casos complicados fora do âmbito da própria família extensa. 68

Há muito, as categorias pajé, cacique e parteira indígenas foram analisadas como um efeito da relação com a sociedade ocidental (Gow, 1996; Oliveira Filho, 1998; Pérez-Gil, 2004, 2007a). 69 Todavia, se a emergência de tais categorias pode ser entendida como uma reinvenção cultural em função do contato interétnico, por outro lado ela não se explica pela simples oposição entre conceitos de hegemonia/ subalternidade (Sahlins, 1997a, 1997b).

Scopel (2013), ao descrever as formas de atenção aos processos de saúdedoença-enfermidade entre os Munduruku da TIKL, destacou a importância de se considerar a pluralidade de atores sociais que atuam como especialistas nesses processos, entre os quais se destacavam indígenas Munduruku, de outras etnias, curadores ribeirinhos, curadores citadinos, além dos profissionais da saúde biomédicos e religiosos de diversas ordens (católicos, protestantes, espíritas, can- 
domblecistas e umbandistas). Ao situar a pluralidade de especialistas indígenas Munduruku (pegadores de desmentidura e rasgadura, benzedores, pessoas que sabem como "pegar barriga" e "curadores pajés"), o autor sublinhou que de modo algum as práticas e diversidades de técnicas observadas poderiam ser restritas a competências específicas. Os pegadores de desmentidura sabiam benzer. Os benzedores sabiam pegar desmentidura e rasgadura. Como vimos, as mulheres que sabiam pegar barriga também benziam e preparavam banhos. A única exceção, neste caso, foi a atuação dos "curadores pajés", cujas práticas incluíam o dom para receber caboclos e transitar no mundo subaquático. Entretanto, conforme assinala Scopel (2013), embora somente os curadores pajés trabalhassem com "espíritos do fundo" e com caboclos, as práticas xamânicas eram parte dos saberes cotidianos dos indígenas na vida da aldeia. Homens e mulheres Munduruku conheciam as plantas que afastavam os bichos do fundo, os encantados, sabiam preparar remédios caseiros para uma diversidade de enfermidades e infortúnios, entre tantos outros saberes de uso pragmático, fosse para tratar doenças, infortúnios ou mal-estares, fosse para prevenção, isto é, para manter a saúde e o bem-estar individual ou familiar.

Cabe sublinhar que, embora seja possível identificar uma diversidade de especialistas Munduruku, seus saberes não constituem algo similar às categorias profissionais biomédicas nem suas práticas se limitam a competências específicas. Isso é central para evitar equívocos nas estratégias de articulação de seus saberes com os serviços de saúde biomédicos e uma medicalização desnecessária da saúde indígena, em especial do parto domiciliar, feito na aldeia. 


\section{Notas}

60 Fala editada para efeito de fluência.

61 Murphy e Murphy (2004: 189) mencionam que entre as mulheres Munduruku do rio Cururu, afluente do rio Tapajós, o trabalho de parto parecia ser mais rápido e as dores menos intensas do que entre as mulheres europeias. Talvez a percepção do casal estivesse relacionada à prática de autoatenção ao parto, tal como encontrei entre as mulheres Munduruku da TIKL, no Amazonas.

62 Por estar interessada nas práticas de autoatenção à gestação, parto e pós-parto, isto é, nas práticas que os sujeitos intencionalmente realizam de maneira bastante autônoma em relação aos especialistas, não fiz esforços para contatar os especialistas Munduruku, como, por exemplo, as "parteiras", para promover uma investigação sobre suas práticas e histórias de vida, com entrevistas, como fizeram Sargent e Bascope (1996), Tornquist (2004) e Ferreira (2013). No entanto, ao longo da pesquisa de campo, encontrei algumas "parteiras" de diferentes aldeias e conversamos sobre partos.

63 Pérez-Gil e Wakanã (2007) encontraram também entre as parteiras Kairiri-Xukuru, Gerinpakó e Karuazu, dos estados de Alagoas e Pernambuco, queixas semelhantes àquelas das parteiras Munduruku quanto à idade avançada como motivação para não realizar partos. Contudo, as autoras propõem que a negativa das parteiras resultava não somente das dificuldades advindas com a idade, mas também da relação com o sistema biomédico e os profissionais da saúde que incentivavam o parto hospitalar e desestimulavam o trabalho das parteiras.

64 O casal Murphy (2004: 189-190) também encontrou uma situação semelhante entre as mulheres Munduruku em trabalho de parto nas aldeias do rio Cururú, Tapajós. Segundo os autores, o parto reunia as mulheres da família, a parturiente era auxiliada por uma mulher mais velha, preferencialmente sua mãe, e nos casos mais complicados o pajé também participava.

65 Pérez-Gil (2007a: 34), ao analisar os dados obtidos em três reuniões realizadas com parteiras, pajés, agentes indígenas de saúde, lideranças indígenas e mulheres do movimento indígena, que congregavam 17 populações indígenas do Acre, pertencentes a três troncos linguísticos diferentes (pano, arawak e arawá), também sugere que o "conceito de parteira (...) [é] uma noção alheia [às populações indígenas] e que foi introduzida através do contato com a sociedade envolvente". Tornquist (2004) afirmou que a atuação médica e as iniciativas profissionalizantes de formação de parteiras, a partir dos séculos XIX e XX envolvia resistências internas e externas ao campo médico. Apesar dessas resistências, a assistência hospitalar ao parto e o aumento do parto cirúrgico no Brasil, em proporções criticadas pela Organização Mundial da Saúde, convergem para um cenário de medicalização crescente da gestação, do parto e do pós-parto, até mesmo entre as populações indígenas

66 É preciso esclarecer que as semelhanças terminam por aqui, pois os relatos das mulheres Munduruku permitem afirmar que a imagem cultural do parto não é a de luta entre mãe e bebê, como ocorria entre os Macha. Ao contrário, entre os Munduruku essa imagem 
parece estar mais ligada à cooperação entre mãe e bebê na hora do trabalho de parto, que juntos se esforçariam para levar a cabo o nascimento.

67 Uma pesquisa sobre os cuidados no pós-parto, feita por meio de entrevistas semiestruturadas com parturientes e familiares em Ribeirão Preto (SP), também menciona a centralidade da "mãe do corpo" para a saúde da mulher (Stefanello, Nakano G Gomes, 2008). Todavia, cumpre esclarecer que encontrei diferenças significativas na leitura do texto quanto à compreensão munduruku sobre a "mãe do corpo". Apesar de, em ambos os contextos, a "mãe do corpo" ter a característica de se deslocar no interior do corpo da mulher, podendo sair do corpo, para as mulheres de Ribeirão Preto a "mãe do corpo" aparece, às vezes, associada ao útero, e seu deslocamento após o parto é motivado pela falta do calor do corpo do bebê recém-nascido. Isto é, a mãe do corpo é dotada de uma agência que não aparece na vida munduruku. Para as mulheres Munduruku, o deslocamento da "mãe do corpo" provocava sofrimentos e doenças. Mas, como vimos, a causa estaria nas ações da própria mulher, ainda que ela não tenha controle direto sobre as razões que a levaram a não se alimentar direito ou a não se cuidar para evitar pegar frio etc.

68 Outros autores também refletiram sobre as dificuldades em situar as pessoas (mulheres ou homens) que auxiliavam no parto como especialistas indígenas, mesmo nos contextos onde era possível identificar a legitimação de alguns para atuar nos partos difíceis (Langdon, 2013; Pérez-Gil, 2007a; Platt, 2002; Sargent G Bascope, 1996).

69 Quanto à figura do xamã, por exemplo, Peter Gow (1996) sugeriu que o xamanismo curativo ayahuasqueiro seria o resultado do contato entre os povos indígenas e a população mestiça na região do Peru. Laura Pérez-Gil (2004) também sugeriu que, entre os Yaminawa e Yawanawa (Pano), a emergência do papel de xamã como especialista em cura é resultado de um processo histórico de contato. Segundo a autora, a prática do xamanismo, antes do contato, não seria exclusividade de especialistas em cura, mas sim prerrogativa de todos os homens em fase adulta. A autora apoia seu argumento nas narrativas indígenas sobre o processo de aprendizado que seria comum a todo jovem ou homem em fase de puberdade, ou seja, todos tinham algum conhecimento sobre práticas xamânicas. De modo diferente, entre os Munduruku, do Tapajós, Murphy (1958) observou que o aprendizado do xamanismo era restrito aos filhos de homens xamãs. Entre os Munduruku, segundo o autor, a iniciação no xamanismo envolvia uma questão de filiação paterna e não era aberta a todo indígena. Murphy comenta que, embora toda criança fosse capaz de imitar a atuação do xamã apenas por observação, a prática do xamanismo era exclusiva dos descendentes de xamãs, tal como o conhecimento esotérico. Scopel (2013) encontrou uma situação diferente para os Munduruku da TIKL, onde a prerrogativa para ser um pajé curador era o reconhecimento de um dom nato, e não uma questão de herança familiar, e a habilidade para o "trabalho" como resultado de um longo processo de cura. 


\section{Atenção Diferenciada e Medicalização da Gestação, do Parto e do Pós-Parto}

Neste capítulo apresento dados sobre o parto na cidade, compreendendo-os em um contexto mais amplo de pluralidade de formas de atenção à saúde. Destaco que as práticas de autoatenção relativas ao parto realizadas pelas famílias Munduruku da Terra Indígena Kwatá-Laranjal (TIKL) permitem compreender o parto na cidade como parte das estratégias de articulação transacionais entre as diversas formas de atenção disponíveis para o grupo. Minha intenção não é apenas ressaltar os antagonismos entre as diferentes formas indígenas e biomédicas de atenção ao parto, mas destacar que se por um lado os indígenas têm feito as articulações entre diferentes formas de atenção à saúde-doença-enfermidade, por outro cabe confrontar o processo amplo de medicalização da saúde indígena que, paradoxalmente, não é acompanhado de aumento da eficiência dos serviços de saúde prestados.

A diretriz da Política Nacional de Atenção à Saúde dos Povos Indígenas (Pnaspi), de 2002, que propõe uma "atenção diferenciada" capaz de respeitar e valorizar os saberes indígenas no trato com a saúde e com a proposta de articulá-los aos serviços biomédicos, envolve alguns desafios que precisam ser mais bem delimitados. Principalmente quando, no cenário internacional, estudiosos dos sistemas de parto em diferentes culturas e contextos diversificados de disponibilidade de tecnologias biomédicas assinalam a expansão mundial da medicalização do parto, já desde o final da década de 1970 (Sargent G Bascope, 1996). Assim, se por um lado a Pnaspi propõe uma articulação entre as práticas indígenas de atenção à saúde e as práticas biomédicas, por outro convive com a marcada expansão do modelo biomédico, pautado por noções particulares sobre doença, tratamento e eficácia. Ao mesmo tempo que a Pnaspi indica uma atenção diferenciada, há também a tendência dos serviços oficiais de saúde a ignorar e até negar os saberes e práticas de autoatenção utilizados pela população. Isso nos leva a questionar o modo como a expansão e a cobertura da atenção primária, isto é, aquela que é ofertada no interior das terras indígenas, vêm sendo realizadas. Embora a Pnaspi indique a capacitação e a formação de recursos humanos para atuar em contextos interculturais como estratégias para a promoção da atenção diferenciada, a autoridade biomédica tem não só dominado as práticas de atenção ao parto em âmbito 
mundial, como também definido os processos de validação dos conhecimentos e das práticas indígenas. ${ }^{70}$

Ao analisar dificuldades encontradas para uma articulação entre os modelos de atenção à saúde-doença indígenas e biomédicos, Langdon (2013: 27) observa que "a distribuição de conhecimentos e os atributos das categorias de especialistas tradicionais não têm correspondência com os da biomedicina". Em consequência, os equívocos da busca por uma equivalência de domínios e de atuação podem gerar também a emergência de especialistas, sem que isso implique reconhecimento e legitimidade perante os demais membros indígenas. No contexto munduruku, conforme sugiro, a distribuição de saberes e práticas não está limitada aos especialistas, mesmo entre aqueles socialmente legitimados (Scopel, 2013).

Alguns exemplos permitem concluir que princípios de ordem social e cultural particulares a cada grupo contribuem, de forma direta, na distribuição dos saberes e nas decisões sobre que especialista consultar durante o parto, e quando consultá-lo. O estudo de Sargent e Bascope (1996) sobre sistemas de parto, por exemplo, em uma comunidade maia, mexicana, os Yaxuna, apresenta a personalidade, a história de vida, as relações de parentesco e o status da família diante dos demais membros da comunidade como os princípios que constituem a legitimidade das especialistas em parto. Outro exemplo é o trabalho de Platt (2002) entre os Macha, um grupo de falantes quéchua, na Bolívia, onde o parto é primeiramente um evento doméstico, de foro íntimo. Lá, a parturiente é auxiliada por seu marido e filhos mais velhos. No primeiro parto, as mulheres podem contar com a ajuda de suas sogras ou outras mulheres mais velhas da vizinhança com experiência de partejar. As "parteiras especializadas" são chamadas apenas em casos de complicações no parto.

No caso das práticas de autoatenção ao parto realizadas pelos Munduruku, observa-se que entre eles também os saberes sobre parto estão horizontalmente distribuídos entre os membros da comunidade, especialmente entre as mulheres mais velhas, embora alguns especialistas como pajés, homens ou mulheres, e "parteiras", possam igualmente ser chamados a atuar na hora do parto. Ademais, os relatos de parto das mulheres Munduruku indicam que os saberes e práticas sobre partos, além de não serem limitados aos especialistas socialmente legitimados, também sinalizam a dificuldade em encontrar uma correspondência com categorias profissionais da biomedicina - por exemplo, a obstetrícia. Além das questões de ordem sociocultural, devemos nos perguntar também sobre qual o impacto do acesso aos recursos biomédicos e das interações sociais com os profissionais da saúde, especialmente com aqueles que atuam na atenção primária, na tomada de decisão sobre quem consultar durante a gestação e sobre onde realizar o parto.

Segundo Langdon (2013), os sistemas de parto indígenas aparecem como um desafio para as políticas públicas de saúde indígena no Brasil relacionado aos 
princípios de articulação com as medicinas indígenas. Em primeiro lugar, porque raramente as práticas de cuidados se encontram limitadas a especialistas, e em segundo porque promovem um conjunto de práticas que dificilmente a biomedicina poderia instrumentalizar. Os exemplos das práticas de autoatenção relativas à gestação, ao parto e ao pós-parto entre os Munduruku da TIKL incluem práticas e valores relacionados com a cosmografia do grupo, promovem relações afetivas significativas na manutenção das relações sociais familiares e repercutem sobre a saúde e a socialidade da família elementar e extensa, além de articular as relações de aliança política.

Portanto, as práticas de autoatenção relativas ao nascimento entre os Munduruku evidenciam uma compreensão ampla acerca da concepção, da gestação, do parto e do pós-parto na qual intervêm elementos socioculturais e cosmográficos pertinentes à reprodução biossocial do grupo, seja a família elementar ou, por consequência, a própria sociedade munduruku. Além disso, os saberes compartilhados sobre o processo de nascimento, como vimos, diferem das concepções anatômicas e fisiológicas praticadas pelo modelo biomédico, restrito a uma abordagem biológica do corpo humano. Isso tem repercussões nos processos de legitimação de determinados saberes como, por exemplo, no reconhecimento das práticas de autoatenção instauradas pelo desejo ou pelo "abalo de criança" na gestação, de aguentar a dor em silêncio no trabalho de parto, de "puxar a mãe do corpo" ou da reclusão no pós-parto, que, embora para os Munduruku sejam fundamentais para a sua saúde e bem-estar, não são aprovadas como um benefício pela biomedicina. Ainda que esta não tenha encontrado uma razão em alguns saberes das medicinas indígenas, "isto não diminui a importância [dessas práticas] para o sistema de parto como um sistema de cuidados à saúde" (Langdon, 2013: 31-32).

É no reconhecimento dessas diferenças entre o modelo indígena e o modelo biomédico no trato com a saúde que, em certo sentido, a Pnaspi se pauta para propor uma atenção diferenciada. Todavia, os profissionais da saúde que atuam nos subsistemas de saúde indígena desconhecem como promover uma atenção diferenciada, bem como as estratégias para incrementar uma articulação entre os saberes indígenas e biomédicos relativos aos processos de saúde/doença/atenção (Diehl, Dias-Scopel G Langdon, 2012; Langdon, 2013).

Além disso, quando determinadas práticas são selecionadas com o objetivo de instrumentalizá-las para incorporá-las em programas de saúde, corre-se o risco de descontextualizá-las, deixando de considerar seu entorno social e cultural. Esse pode ser o resultado das tentativas de integração dos especialistas indígenas nos programas de saúde sobre o parto. Talvez um efeito das tentativas de integrar indígenas ao modelo biomédico tenha sido o caso das "parteiras" Munduruku, em que a iniciativa de um curso para parteiras, ao buscar identificar especialistas, fomentou a emergência de um papel social, a "parteira" que atua entre diferentes 
famílias extensas. Então, a questão que se coloca é: quais são as refrações dessas iniciativas nas relações sociais do grupo e também nas relações sociais com os demais membros da equipe de saúde dos serviços biomédicos?

Ao diferenciar as noções de articulação e de integração, Langdon (2013: 32) identifica outro problema como consequência de estratégias equivocadas:

Oposta ao princípio da articulação, a noção de integração implica em instrumentalização das práticas da medicina tradicional percebidas como eficazes pela ciência ocidental. A noção de integração de práticas tradicionais nas ações de saúde realizadas pelas equipes médicas tira a especificidade do outro. A estratégia de integração das práticas tradicionais remete ao problema da hegemonia e dominação da biomedicina em decidir quais práticas são legítimas, quais devem ser cultivadas e quais devem ser eliminadas.

É necessário reconhecer os processos de indigenização, conforme sintetizou Sahlins (2007), para indicar a agência das populações indígenas nos processos de expansão das fronteiras capitalistas, de modo a prover o próprio desenvolvimento. É preciso considerar também que os contextos de pluralidade médica implicam juízos de valor sobre as diferentes formas de atenção à saúde, doença e tratamento (Menéndez, 2005; Sargent G Bascope, 1996). Conforme assinala Ortner (2006), se por um lado os atores sociais, individuais ou coletivos, têm agência capaz de reproduzir e transformar relações estruturais e sistematizadas ou a elas resistir, por outro essas mesmas relações sistemáticas coagem os sujeitos e constituem os instrumentos e elementos que moldam suas subjetividades. Portanto, no processo de expansão biomédica é preciso ter em conta os paradoxos advindos dos confrontos entre diversos regimes de poder e intencionalidades. Isso significa observar em que nível da rede de saúde na qual o Subsistema de Atenção à Saúde Indígena (Sasisus) está inserido há uma promoção e valorização de algumas formas de atenção à saúde e às enfermidades em detrimento e com desvalorização de outras. Afinal, o Sasisus integra diferentes níveis de atenção: a atenção primária, ofertada no interior das aldeias indígenas, e as atenções de média e alta complexidade, ofertadas nas redes do Sistema Único de Saúde (SUS).

\section{O parto na cidade}

Desde a ampliação da cobertura e do acesso aos serviços de saúde biomédicos, o parto hospitalar também se tornou um recurso opcional utilizado pelas mulheres indígenas. E as mulheres Munduruku o têm utilizado, realizando partos no hospital público de Nova Olinda do Norte, Amazonas, cidade vizinha à TIKL. Sugiro que a expansão crescente da medicalização do parto e o acesso aos serviços de atenção pré-natal são parte dos fatores macrossociais que interveem na escolha 
do local de parto. Nesta seção, apresentarei dados de observação participante para circunscrever o ponto de vista das mulheres Munduruku sobre a escolha do local de parto. As rodas de conversa ao entardecer foram os locais e momentos privilegiados para minha aproximação dos fatores microssociais envolvidos no processo de decisão sobre onde parir. As conversas com os profissionais da Equipe Multidisciplinar de Saúde Indígena (EMSI) que atuavam nos polos da TIKL, na época da pesquisa de campo, foram importantes também para que eu compreendesse as razões que cooperavam no processo de tomada de decisões das gestantes Munduruku. Escrevo sobre isso para que o leitor compreenda os sentidos atribuídos ao parto hospitalar, os quais resultam de uma série de relações sociais entre as gestantes, seus maridos, familiares e também os especialistas indígenas como "parteiras", pajés e profissionais da EMSI.

Embora os dados epidemiológicos que obtive durante o trabalho de campo - acerca das ações dos serviços de atenção biomédica à gestação, parto e pós-parto ofertados aos indígenas da TIKL - não permitam avaliar uma tendência nos indicadores de saúde, ao menos servem para indicar que as mulheres Munduruku têm realizado partos na aldeia e partos no hospital e, em alguns casos, cesáreas.

Tabela 1 - Partos na aldeia e na cidade. Polo-Base Kwatá, 2008-2010

\begin{tabular}{c|c|c|c|c|c}
\hline Ano & Total de partos & \multicolumn{2}{|c|}{ Partos na aldeia } & \multicolumn{2}{c}{ Partos no hospital } \\
\hline 2008 & 28 & 22 & $79 \%$ & 6 & $21 \%$ \\
\hline 2009 & 49 & 22 & $45 \%$ & 27 & $55 \%$ \\
\hline 2010 & 66 & 33 & $50 \%$ & 33 & $50 \%$ \\
\hline
\end{tabular}

Tabela 2 - Partos cesarianos. Polo-Base Kwatá, 2008-2010

\begin{tabular}{c|c|c|c}
\hline Ano & Total de partos & \multicolumn{2}{|c}{ Número de cesáreas } \\
\hline 2008 & 28 & 2 & $7 \%$ \\
\hline 2009 & 49 & 10 & $20 \%$ \\
\hline 2010 & 66 & 11 & $17 \%$ \\
\hline
\end{tabular}

Fontes: os dados relativos aos partos das mulheres indígenas Munduruku foram obtidos em duas fontes distintas; os dados referentes ao ano de 2008 e 2009 foram coletados em 2010 no Distrito Sanitário Especial Indígena Manaus, e os dados de 2010 foram obtidos em 2011 diretamente com a enfermeira do Polo-Base Kwatá, na aldeia homônima.

Esses dados indicam que em 2008 os partos domiciliares corresponderam a $79 \%$ do total de partos realizados naquele ano nas aldeias adstritas ao Polo-Base Kwatá. Do total de partos, 21\% foram hospitalares. Note-se que 7\% do total foram cesáreas. Em 2009, 45\% foram feitos na aldeia e 55\% no hospital, sendo que as 
cesarianas representaram 20\% do total de partos. Em 2010, 50\% foram hospitalares e, destes, $17 \%$ foram cesáreas. Nesses dados, chama a atenção a alta porcentagem de partos domiciliares, realizados nas aldeias. Todavia, destaca-se também a porcentagem de cesáreas referente aos partos hospitalares, sobretudo se considerarmos os dados relativos ao ano de 2009, quando mais da metade dos partos em hospitais foram cesarianos.

A medicalização do parto já tem longa data no contexto urbano brasileiro, mas ainda é um fato recente para as populações indígenas no Brasil. Entre os Munduruku da aldeia Kwatá, nenhuma mulher acima de 40 anos tinha dúvida quanto ao local do parto, que seria em sua casa, na aldeia, com o auxílio de uma mulher mais velha ou de uma "parteira" ou pajé. Do mesmo modo, os cuidados relativos à gestação eram realizados no interior da família extensa, eventualmente contando com o recurso a um(a) especialista indígena. Atualmente, a medicalização do parto entre as mulheres Munduruku da TIKL inicia-se já na gestação, com o programa de acompanhamento pré-natal, uma medida das políticas públicas de saúde, mas também daquelas voltadas para a diminuição da desigualdade social no Brasil, que incentivam as mulheres a realizarem o controle mensal durante a gestação no sistema de saúde, apesar do acesso restrito à alta tecnologia obstétrica. Entretanto, parece que as ideologias subjacentes ao modelo médico hegemônico antecedem e persistem, independentemente do contexto de baixa ou alta tecnologia obstétrica. Assim, não obstante o acesso ou não aos recursos biomédicos, sobretudo aqueles envolvidos na medicalização do parto, é fato que o discurso e a ideologia biomédicos sobre a necessidade de parto hospitalar e de laqueadura eram temas de conversação e de crítica entre as mulheres Munduruku da TIKL, já à época da pesquisa de campo.

Os dados secundários comprovam que as mulheres Munduruku realizaram partos no hospital. Todavia, os motivos envolvidos no processo de tomada de decisão sobre onde parir ficam mais claros quando analisamos os dados obtidos durante o trabalho de campo. Conforme dito, concentrei minhas atividades de observação participante em um segmento residencial. Das sete mulheres gestantes da família extensa que moravam nesse segmento, três optaram por parir na cidade. Lana optou pelo parto hospitalar porque estava decidida a fazer a laqueadura, procedimento cirúrgico de esterilização feminina. Por conta dessa decisão, Lana fez cesariana.

A laqueadura era tema de conversa entre as mulheres Munduruku, especialmente quando o assunto era a escolha pelo parto hospitalar ou por um método permanente e efetivo contra a concepção. Uma professora Munduruku, ao tentar entender por que eu vinha de uma família tão pequena, com apenas uma irmã e um irmão, apresentou as razões para ter feito laqueadura. Sua última gestação havia sido menos de um ano atrás. Ela vinha de uma família numerosa e contou que seu pai a aconselhou a se casar e "a fazer filhos para não acabar a geração". A professora se referia à continuação da família ao falar da geração. Ela observou 
minha procedência de uma diminuta família e concluiu que "a sociedade envolvente pensa diferente". Exemplificou essa diferença rememorando as recomendações que as mulheres Munduruku escutavam quando faziam o pré-natal: "Dizem que muito filho faz mal para a saúde da mulher, que filho fica criado assim, ao vento".

Cumpre esclarecer que, segundo consta no manual técnico Pré-Natal e Puerpério: atenção qualificada e humanizada, cabe aos profissionais da atenção básica promover "ações educativas" sobre, entre outras, a "importância do planejamento familiar, num contexto de escolha informada, com incentivo à dupla proteção" (Brasil, 2005: 32-34). Ao que parece, na ação educativa para o planejamento familiar realizada durante as consultas pré-natal na TIKL fala-se sobre um número ideal de filhos (Dias-Scopel, Scopel G Langdon, 2017). Todavia, não posso afirmar que as EMSIs tenham incluído a recomendação de fazer laqueadura em suas ações educativas no pré-natal. Entretanto, a avaliação de que atualmente há uma tendência à procura pela laqueadura foi comum entre muitas mulheres Munduruku. Isso mesmo em um contexto em que as mulheres compartilhavam diversos saberes sobre práticas anticonceptivas por meio do uso de remédios caseiros e de métodos biomédicos, em especial "injeção para não engravidar" (anticoncepcional injetável), obtidos gratuitamente nos postos de saúde de Nova Olinda do Norte. De qualquer forma, qualquer que tenha sido a recomendação feita pelos profissionais da EMSI durante o acompanhamento pré-natal relativo ao planejamento familiar, a laqueadura é um procedimento biomédico que vem ganhando espaço entre as práticas anticonceptivas das mulheres Munduruku, segundo uma opinião comum, inclusive dos profissionais da saúde. Além disso, a indicação do parto hospitalar tende a ser reiteradamente afirmada durante as consultas do pré-natal.

Segundo uma das técnicas de enfermagem do Polo-Base Laranjal, "toda primípara mandamos para Nova Olinda do Norte", ou seja, para a rede municipal do SUS para realizar o parto hospitalar. Curiosamente, a idade e a inexperiência em parto também apareceram nas avaliações das mulheres Munduruku com quem conversei nas aldeias Kwatá, Niterói, Caioé e Fronteira, adstritas ao Polo-Base Kwatá, como critérios considerados no processo decisório sobre o local do parto. Foi, por exemplo, o caso de Itapema, uma jovem de 17 ou 18 anos, que teve seu primeiro parto no hospital de Nova Olinda do Norte. Quando visitei Itapema, neta de minha anfitriã Ceci, que estava morando com sua mãe, Rita, enquanto cumpria o resguardo "de parto", foi-me dito que ela havia sido levada para o hospital porque "era muito nova". Foi Rita quem afirmou o motivo da escolha pelo parto hospitalar e foi ela quem acompanhou sua filha durante e após o parto, enquanto permaneceram na Casa de Apoio à Saúde do Índio (Casai). A permanência na Casai após o parto, por um período que variou entre sete e 15 dias, foi seguido pelas mulheres Munduruku como parte das práticas de autoatenção ao pós-parto. Outras mulheres realizaram o parto hospitalar pelo mesmo motivo que levou Itapema à escolha 
desse local para parir durante o período da pesquisa de campo. Gigi, outra jovem de 16 anos de idade, também fez o primeiro parto no hospital. A mãe de Gigi era agente indígena de saúde (AIS) e a acompanhou durante e após o parto, quando permaneceram na Casai. Novamente, a mãe de Gigi justificou a escolha com a idade da filha, "muito nova". Gigi estava morando com os pais porque ficara viúva pouco antes do nascimento do filho.

Quando fiz observação participante na Casai, a maioria das pacientes em trânsito, isto é, que estavam pernoitando ali, era gestante ou estava no pós-parto. Naquele espaço, outro fator foi elencado como critério para a eleição do parto hospitalar pelas mulheres e seus acompanhantes - na maioria dos casos, as mães das gestantes ou seus maridos. A busca por segurança diante da virtualidade de um parto complicado motivou tanto gestantes primíparas quanto experientes a buscar o parto hospitalar. A principal razão por elas enunciada foi evitar a morte da mãe ou do bebê por causa de possíveis complicações na hora do parto. Assim, o parto hospitalar apareceu como alternativa relacionada à expectativa de um parto seguro. A possibilidade de um parto complicado, especialmente na época da seca, quando aumentam as dificuldades de deslocamento das aldeias até o polo-base, onde a EMSI atuava, ou até a cidade de Nova Olinda do Norte para ser assistida no hospital, motivou muitas famílias de diferentes aldeias a procurarem o parto hospitalar com antecedência, fosse primeiro parto ou não. Foi o caso, por exemplo, de Vani e de Laura. Vani e seu esposo, à época da pesquisa de campo um AIS e conselheiro distrital de saúde, optaram pelo parto hospitalar porque o deslocamento seria mais difícil e demorado, por conta das distâncias que aumentavam na época da seca, caso houvesse alguma complicação. Eles moravam em uma pequena aldeia adstrita ao Polo-Base Laranjal, no rio Mari-Mari, não muito distante da aldeia onde o polo-base ficava sediado. Vani foi acompanhada de seu marido e os dois ficaram na Casai por 15 dias após o parto. Ela tinha mais de 30 anos e era mãe de cinco crianças, das quais apenas as duas últimas nasceram no hospital. As outras três meninas haviam nascido na aldeia com a ajuda da "parteira" da aldeia Mucajá, próxima daquela em que moravam. Laura, por sua vez, morava em uma distante aldeia no rio Canumã, a horas de viagem da aldeia onde a EMSI do polo-base ficava sediada. Ela e seu esposo, também um AIS, optaram pelo parto hospitalar da última filha, com 5 meses na época da pesquisa de campo, por receio de um parto complicado e por conta da distância dessa aldeia, inclusive, das demais aldeias naquele rio. Além disso, os pais dela já eram falecidos e os pais dele moravam em Nova Olinda do Norte. Laura também tinha mais de 30 anos e era mãe de sete crianças.

É compreensível o receio dos Munduruku e a preocupação em deslocar uma mulher em trabalho de parto, a qualquer hora do dia ou da noite, como motivação para optar antecipadamente pelo parto hospitalar, na medida em que, em suas ações, 
alguns profissionais da EMSI manifestaram uma rejeição às práticas das "parteiras". Conforme expressou uma técnica de enfermagem do Polo-Base Laranjal, "diz que as parteiras mandam fazer força antes da hora, já a equipe [EMSI] avalia pela dilatação". Por esse motivo, quando a EMSI chegou para fazer o parto "a mulher já estava toda atirada, cansada". Embora ela estivesse falando especificamente de um parto realizado no interior da TIKL, no qual havia participado ativamente, tendo mesmo chegado a realizar uma episiotomia, sugiro que o testemunho dessa técnica de enfermagem possa estar evidenciando um discurso biologicista e medicalizado sobre o parto. Ainda mais, sugiro que esse tipo de discurso torna visível a maneira como profissionais da saúde reforçam uma relação de subordinação da mulher e dos saberes indígenas ao saber biomédico.

Como vimos, esses discursos contradizem a narrativa de Araci, por exemplo, sobre a hora correta de fazer força. Essas contradições emergem em um contexto no qual muitos partos foram realizados com sucesso em casa, com o auxílio das mulheres mais velhas da família extensa ou com a participação dos especialistas indígenas e, ainda, eventualmente, dos profissionais da saúde. Em certo sentido, a necessidade de parto hospitalar, incentivada pelos profissionais da EMSI - seja de forma direta, com o encaminhamento das primíparas à rede do SUS, seja de forma indireta, com a desqualificação das práticas munduruku relativas ao parto -, contribuiu para a construção do parto como um evento cercado de riscos e, principalmente, para sua medicalização.

Todavia, a ideia de risco de vida, como situação de vulnerabilidade que pode levar à morte da parturiente e do bebê, não é totalmente estranha aos Munduruku. A procura por partos hospitalares foi também uma demanda de algumas mulheres indígenas cuja motivação teve origem nas avaliações que emergiram da prática de "pegar barriga". Iara estava planejando parir no hospital de Nova Olinda do Norte porque tanto o pajé quanto sua cunhada afirmaram que seu bebê estava "sentado" quando "pegaram a barriga" dela ao longo da gestação. Conforme vimos, Iara fora "pegar barriga" durante todo o período da última etapa da pesquisa de campo para "ajeitar o bebê no nascedouro", ou seja, para endireitar a posição fetal, e decidira parir no hospital da cidade de Nova Olinda do Norte incentivada pelo pajé que a acompanhou durante a gestação. Essa decisão estava embasada no diálogo com um especialista Munduruku e na avaliação da posição fetal, cuja inadequação resultaria em um parto difícil e representava riscos de vida para a mãe e, especialmente, para o bebê, segundo a memória social compartilhada entre os Munduruku acerca de partos seguidos de morte por causa da posição do bebê na hora do nascimento. As mulheres mais velhas contavam casos de óbito neonatal de bebês que nasceram "sentados" ou "de pé" e casos de partos bem-sucedidos, apesar da posição inadequada do bebê na hora do nascimento, principalmente por conta da atuação de pajés e "parteiras". 
Em contrapartida, nesse cenário é importante ainda considerar os riscos das cesáreas desnecessárias para a saúde materno-infantil. Desde 1998 o Ministério da Saúde tem incentivado a diminuição do número de cesáreas, por reconhecer que esse procedimento tem contribuído para os índices de morbimortalidade neonatal:

\begin{abstract}
Embora essa realidade tenha melhorado progressivamente nos últimos anos, a assistência materno-infantil é ainda um significativo problema de Saúde Pública no País. Em algumas regiões, registram-se, ainda, alarmantes índices de morbimortalidade materna e neonatal. Isso decorre por diversos fatores, como a precariedade ou inexistência da realização de pré-natal, insuficiência nas condições gerais de infraestrutura e de materiais e equipamentos, capacidade instalada e operacional dos hospitais que realizam partos no País. A alta taxa de cesarianas verificada tem contribuído significativamente para a ampliação dessa morbimortalidade. O parto cirúrgico traz cerca de sete vezes mais risco para a mãe e o bebê. (Brasil, 2002b: 81)
\end{abstract}

No Brasil e mundo afora, há inúmeros fatores que interferem na opção pelo parto hospitalar (Pérez-Gil, 2007a; Sargent G Bascope, 1996). Podemos citar, por exemplo, questões logísticas de deslocamento e proximidade dos centros urbanos; questões de ordem sociocultural e histórica; e a crescente expansão do modelo biomédico e da medicalização do parto. No contexto da TIKL, de alguma forma o sistema de saúde tem incentivado e estimulado as mulheres Munduruku a parir nos hospitais da cidade. E, de alguma forma, ideias de planificação familiar, orientadas por uma visão particular de desenvolvimento socioeconômico, têm incentivado algumas mulheres Munduruku a realizar a laqueadura, o que tem impactado diretamente sobre a realização de cesarianas. A preferência pelo parto cesariano tem sido um ponto crucial na fala dos Munduruku de Canumã, especialmente quando associado à prática da laqueadura. As mulheres Munduruku reconheceram a busca pela laqueadura como resultado do diálogo e do contato com os serviços de saúde ofertados pelo governo brasileiro.

Em síntese, a escolha pelo parto hospitalar foi motivada por diferentes expectativas construídas a partir do diálogo com diversos atores sociais, entre os quais mães, maridos, especialistas indígenas (pajé e "parteiras") e profissionais da saúde. Embora a motivação fosse diferente conforme as relações sociais estabelecidas, a ideia de risco ou de um parto difícil apresenta-se, em determinadas circunstâncias, como um paralelo entre as práticas indígenas e as biomédicas relativas ao nascimento, cujo foco é o bem-estar da mãe e do bebê. Nesse sentido, os profissionais da saúde e as práticas de medicalização do parto encontram um terreno fértil e, portanto, impõem a necessidade de uma atuação crítica a fim de evitar a medicalização excessiva e desnecessária, embasada mais em um procedimento padrão do que em uma avaliação caso a caso. 


\section{Nota}

70 Sargent e Bascope (1996) concluíram que mesmo naqueles contextos em que se verificava acesso restrito à alta tecnologia, isto é, nos hospitais, com profissionais e aparatos biomédicos, era possível identificar a expansão da autoridade biomédica sobre o parto. 


\section{O Cotidiano e o Extraordinário: o resguardo entre os Munduruku}

Em termos gerais, o resguardo pode ser entendido como um conjunto de práticas manejadas com a intenção de prevenir ou minimizar enfermidades e infortúnios que, em última instância, implicam risco de vida. Dirijo o foco para o resguardo do pós-parto, contudo essa categoria pode ser aplicada em outros contextos. Segundo os Munduruku, o descumprimento do resguardo pode causar a morte tanto daquele que violou as prescrições de autoatenção no resguardo como de qualquer outra pessoa próxima, principalmente as crianças. A palavra resguardo, de sentido genérico, designa um conjunto de prescrições e restrições alimentares referentes a atividades físicas, aos espaços de circulação, abrangendo um tempo socialmente marcado, em que a pessoa deve se dedicar a cumpri-lo. Os eventos que deflagram a necessidade de cumprir o resguardo são vários: a ida ao cemitério no dia dos Finados, o luto na Semana Santa, a convalescença causada por animais peçonhentos (cobra e arraia), a menstruação e o pós-parto.

De todos esses eventos, interessa-me apresentar as práticas de autoatenção manejadas no resguardo do pós-parto, devido ao interesse e aos esforços nativos para o cumprimento das prescrições e restrições associadas, uma vez que as consequências podem se estender aos seus filhos recém-nascidos e se perpetuar ao longo de suas vidas, repercutindo diretamente sobre a qualidade de vida na velhice. Se pensarmos em termos processuais, o resguardo do pós-parto pode ser compreendido como etapa final do processo de nascimento, no qual mãe e pai se esforçam e cooperam mutuamente para garantir o bem-estar do recém-nascido e para manter sua própria saúde. Se bem que os pais agirão também em momentos específicos na vida dos filhos de modo incisivo na intenção de lhes assegurar o desenvolvimento pleno das características físicas e morais coerentes com os valores éticos e estéticos munduruku relacionados com a manutenção do bem-estar e da saúde ao longo da vida.

Apresentarei aqui principalmente os dados de observação participante sobre o resguardo do pós-parto dos casais que acompanhei. A descrição das práticas de autoatenção ao pós-parto foi enriquecida com relatos de casais sobre suas experiências anteriores. 
A partir da descrição e análise dos dados etnográficos apresentados, nos aproximamos da compreensão da construção social do corpo feminino saudável para os Munduruku, do seu lugar na cosmografia e dos limites para a manutenção desse corpo/pessoa saudável. Na antropologia, o corpo pode abranger três dimensões: individual, social e política (Lock G Scheper-Hughes, 1996: 51). Essas dimensões são extremamente importantes quando se trata de produzir dados contextualizados sobre a saúde, pois frequentemente os estudos não antropológicos focalizam apenas o corpo como unidade biológica, sem enfatizar sua dimensão social. Na antropologia, a constituição do corpo é vista como um processo contínuo, marcado por complexas elaborações práticas - rituais, manipulação, pinturas, perfurações, massagens, dietas alimentares, reclusão etc. - repletas de significados compositores das identidades individuais e coletivas (Mauss, 2003a; Turner, 1980; Seeger, Da Matta G Viveiros de Castro, 1979). Em trabalhos clássicos para a antropologia, Marcel Mauss (2003a, 2003b) destacou que não apenas a pessoa - como categoria jurídica e moral - é construída social e historicamente, mas o corpo e seus usos também o são. Mauss indicou que a "arte de utilizar o corpo" é aprendida através de diferentes processos educativos, os quais criam e incorporam um habitus particular de um povo e de uma época. Entre os Munduruku, as práticas de resguardo constituem práticas de autoatenção cujos efeitos se fazem sentir para toda a vida, especialmente no caso das mulheres.

\section{O resguardo do pós-parto munduruku: o sangue, o corpo e a vida}

Após o nascimento de um bebê, os Munduruku ingressam em um período de liminaridade (Turner, 1974) em que o corpo, o sangue e a saúde estão no centro de suas preocupações. Os Munduruku vivenciam o período do pós-parto atentos ao conjunto de prescrições de práticas que incidem sobre seus corpos e atividades cotidianas, a que denominam "resguardo de parto", "resguardo de mulher parida" ou, simplesmente, "resguardo". Essas prescrições incluem dietas alimentares, proibição de certas atividades e reclusão. Entre os Munduruku, não somente a mãe, mas também o pai e o recém-nascido devem cumprir o resguardo. O resguardo do pós-parto abrange um tempo socialmente marcado e se caracteriza pela orquestração de um conjunto de práticas intencionalmente realizado pelos Munduruku com o objetivo pragmático de manter a saúde, prevenir doenças e evitar a morte do recém-nascido e da mãe. 


\section{O sangue do parto: impureza e perigo}

Um evento propiciado pelo desencontro entre práticas culturais relativas ao pós-parto auxiliará o leitor a compreender o significado do sangue no resguardo do parto para os Munduruku.

Estávamos na aldeia Niterói, onde fomos recebidos pelo curador Guaraciaba e sua esposa, quando seu vizinho, um índio da etnia tukano, apareceu para conversar. Ele havia se mudado do Alto Rio Negro para a aldeia Niterói, com o consentimento das lideranças munduruku, alguns anos antes, junto com a esposa e os filhos. Havia acabado de construir uma casa para si a poucos metros de distância da casa de Guaraciaba. Certa vez, eu estava conversando com Guaraciaba e Mia sobre o "assombro de bicho", doença cuja causa pode ser o cheiro do sangue menstrual, conforme descrevi no Capítulo 3. O índio Tukano ouviu nossa conversa e contou o drama que vivenciou no primeiro parto de sua mulher, quando ainda morava na aldeia Kwatá. Ela pariu em casa com a ajuda dele. Depois que o bebê nasceu, ele pegou os panos e roupas sujas de sangue e foi até a beira para lavá-las, com a intenção de ajudar a esposa. Fazia pouco tempo que moravam na Terra Indígena Kwatá-Laranjal (TIKL) e eles não estavam a par das restrições munduruku sobre pós-parto. Os vizinhos Munduruku, ao verem que ele lavava os panos sujos de sangue à beira do rio, reagiram efusivamente e muito irritados: "Eles só faltavam me bater, dizendo que eu ia matar meu filho!". Fizeram com que ele interrompesse a lavação e que a mulher cumprisse rigorosamente a reclusão de quarenta dias após o parto. O Tukano e sua família passaram por uma situação de estranhamento e constrangimento quando cometeram uma falta em relação às práticas profiláticas de resguardo munduruku considerada grave pelos vizinhos. Eles desconheciam as práticas de autoatenção ao resguardo manejadas pelos Munduruku, sobretudo aquelas resultantes do contato com o sangue do parto.

Para os Munduruku, os panos e as roupas utilizados no parto e com vestígios de sangue são perigosos. Do ponto de vista deles, panos sujos de sangue do parto estão contaminados com uma substância poderosa capaz de deflagrar relações indesejáveis com os seres encantados que habitam o mundo subaquático, principalmente os botos. Por isso, não haveria lugar mais inapropriado para se livrar do sangue de parto do que a beira do rio. Assim, os panos sujos ou foram enterrados ou queimados pelo pai, segundo os relatos dos Munduruku.

"O sangue da gente é muito forte", explicou-me uma parteira da aldeia Kwatá, ao dizer por que não se banhava no rio durante oito dias após o parto. O sangue do parto tem a mesma propriedade que o sangue menstrual, o cheiro forte capaz de atrair os botos. Todavia, se o sangue menstrual tem um estatuto ambíguo - ao mesmo tempo que é fonte de perigo é também fonte de vida, é substância necessária para a procriação, para a "produção" de crianças -, o sangue de parto é 
exclusivamente fonte de impureza e perigo. Ao "pegar criança", a "parteira" entra em contato direto com o sangue do parto, cumprindo, assim, determinadas práticas de resguardo, como evitar banhar-se à beira do rio. ${ }^{71}$ Há, entretanto, estratégias para tirar o pitiú do sangue praticadas pelas "parteiras" Munduruku, como lavar-se com plantas cheirosas, isto é, plantas cujo odor forte espanta os botos encantados. Outra "parteira", que morava na Emprezinha (parte distante da aldeia Kwatá), relatou cumprir uma dieta alimentar como parte do resguardo pós-parto.

A mulher que pariu, a mãe, também deve se resguardar. O resguardo "de mulher parida" dura cerca de 40 a 45 dias, nunca menos, ou até mais, entre 90 e 120 dias. A maioria das mulheres que acompanhei durante o resguardo cumpriu entre 40 e 45 dias de práticas de autoatenção relativas ao pós-parto. Somente aquelas que eram também pajés, isto é, curadoras que trabalhavam com espíritos do fundo, encantados e caboclos, cumpriram o resguardo de três ou quatro meses. Embora as práticas de autoatenção ao pós-parto fossem as mesmas, as curadoras eram proibidas de realizar seu trabalho com os seres encantados ou caboclos. Contudo, podiam benzer, fazer fricções, costurar, entre outras técnicas de tratamento que dominavam (Scopel, 2013).

As práticas de autoatenção relativas ao resguardo variavam ao longo dos quarenta dias e também havia restrições específicas para a mulher, o homem e o bebê. Ao longo do trabalho de campo, pude acompanhar oito casais em diferentes momentos do resguardo. Todas as mulheres "paridas" cumpriram um resguardo semelhante ao da menstruação. Enquanto estavam com sangramento, não foram se banhar no rio ou na cacimba, conforme a época específica do ano. Nesse período, a participação dos homens, maridos e pais, foi central para auxiliá-las no cumprimento dessa prescrição, ao levarem água até a casa. As mulheres mais velhas me explicaram que o sangramento se devia ao "útero ferido" ou "ferida no útero", e todos, homens e mulheres, eram unânimes em afirmar que esse sangue tinha um odor que atraía os botos encantados. As consequências da aproximação dos botos eram as mesmas que decorriam da quebra do resguardo da menstruação. Os botos poderiam se agradar da mulher parida ou de qualquer outra pessoa que passasse no rastro deixado pela mulher com sangramento. Seguindo o cheiro do sangue, que assim como o da menstruação se parece com o do ananás, o boto poderia se aproximar também do recém-nascido, agradar-se dele e levá-lo para o "encante". Isso significaria um processo de doença sucedido de morte. E a "mulher parida", por sua vez, adoeceria seriamente, podendo ficar doida, "engravidar de bicho" e morrer. Assim, a noção de rastro define a característica volátil do sangue, sua capacidade de se propagar no ar.

Insisto que a gestação, o parto e o pós-parto não eram percebidos como eventos de doença. Embora a expressão "ferida no útero" possa evocar em nossas mentes uma associação com doença, só seria correto afirmá-lo se essa noção tam- 
bém fosse compreendida de forma ampla. Do mesmo modo que a noção de saúde engloba uma ideia de harmonia nas relações sociais, as quais abarcam dimensões políticas, territoriais, cosmológicas e interétnicas, além de processos corporais, também a noção de doença é mais ampla que aquela do modelo biomédico. No caso específico, o resguardo "da mulher parida" sinaliza um estado liminar e não uma disfunção orgânica, químico-física ou psicológica. Esse estado liminar coloca a mãe e o bebê em uma situação de maior vulnerabilidade diante da complexa cosmografia munduruku. Nesse caso, a reclusão da mãe e do bebê significa uma forma de se resguardar, o que, em termos analíticos, parece explicitar uma prática de autoatenção.

\section{A reclusão e a dieta alimentar}

As mulheres da família extensa com a qual morei comentaram que Lara havia tido outro menino na noite anterior. Estávamos sentadas em frente à casa de Ceci para mais um final de tarde nas rodas de conversa, em novembro de 2010. O tema não era o parto, mas o fato de ter nascido mais um menino, o sexto filho homem de Lara. Fiquei entusiasmada em saber que o parto já havia acontecido, pois frequentava quase diariamente a casa dela, e isso nos aproximou. Lara tornara-se uma amiga e interlocutora-chave, com ela eu passava horas conversando e brincando com seus filhos. Senti-me motivada a lhe fazer uma visita imediatamente e expressei em voz alta meu anseio. Porém, nenhuma mulher ali demonstrou o mesmo interesse.

Lara não era membro daquela família extensa, embora tanto ela quanto Ceci reconhecessem que eram parentes. Todavia, Lara frequentemente participava das rodas de conversa em frente à casa de Ceci, a quem se referia como vovó. Ao analisar as genealogias, identifiquei que o marido de Lara era neto de uma cunhada de Ceci. Portanto, Lara estava inserida em uma família extensa que reconhecia um grau de parentesco próximo com a família extensa de Ceci. Então, antes de sair, perguntei como ficaram sabendo do parto de Lara. Araci conversou com o médico da Equipe Multiprofissional de Saúde Indígena (EMSI) e ele lhe contara. Ceci, então, sugeriu gentilmente que eu esperasse para fazer a visita no dia seguinte, pois já estava anoitecendo. Segui o conselho de minha anfitriã, pois naquele momento lembrei que fazia parte do "resguardo de ferroada de arraia" evitar visitas. Jô, que já havia sido ferroado por arraia três vezes em sua vida, explicou-me como era esse resguardo: "igualmente ao resguardo de parto". Ele ficou oito dias sem sair de casa, fez uma dieta alimentar e passou a evitar visitas, após cruzar com a sobrinha de sua esposa. A sobrinha estava grávida e perguntou o que havia acontecido ao vê-lo voltar do rio mancando. Jô disse que naquele momento toda a dor voltou com muito 
mais intensidade, se comparada ao momento em que havia pisado na arraia. Eu não estava grávida naquele momento, nem Lara havia sido ferroada por arraia, embora estivesse em um estado liminar de maior vulnerabilidade. Entretanto, lembrei que as mulheres daquela família extensa não ficavam visitando o casal Nora e Batista, neto de minha anfitriã Ceci, os quais moravam no mesmo segmento residencial, quando estavam no resguardo de parto, em fevereiro de 2010. Todavia, três dias após o parto, ainda pela manhã, fui até a casa de Lara, pois como na primeira etapa de trabalho de campo eu havia frequentado a casa de Nora e Batista desde o terceiro dia após o parto sem que isso tivesse gerado qualquer constrangimento, resolvi visitá-la. Afinal, eu tinha um interesse especial.

Ao me aproximar da casa de Lara notei que as janelas e a porta da casa estavam fechadas, apesar do sol e do calor. Por um instante hesitei, pois foi a primeira vez que vi a casa de Lara assim fechada. Respirei fundo e bati na porta. Em alguns segundos, seu filho mais velho, à época com 11 anos, abriu a porta e anunciou: "Mamãe, é a dona Raquel". Ela me pediu que entrasse e pela primeira vez me recebeu em seu quarto. Dentro da casa, percebi que havia duas janelas abertas, uma nos fundos, na cozinha, e outra na sala. Lara estava deitada em uma rede ao lado da rede em que seu bebê recém-nascido dormia. Ela estava bem, sorridente, e comentou: "Mais um menino". Abriu um pouco a janela do quarto, uma pequena fresta, e colocou uma toalha como cortina, que filtrava a luz direta do sol e qualquer vento ou olhar vindo de fora. Na casa estavam apenas Lara, seu filho mais velho e o mais novo, com 2 anos de idade. O marido havia ido pescar e os outros três filhos, com 4, 6 e 8 anos, estavam brincando na casa da vizinha. Sentei-me no canto do quarto e ali conversamos sobre seu parto, como ela estava naquele dia, o futuro nome do bebê e o resguardo de parto.

Lara contou que estava tomando banho "ali", em um canto do quarto. Ao responder por que não ia se banhar no rio, ela disse: "Porque o sangue é muito pitiú e o corpo diz que está aberto". Conforme já vimos, pitiú é uma palavra que designa cheiros fortes e desagradáveis. Embora o sangramento do pós-parto seja pitiú para os Munduruku, para os botos o seu cheiro é doce. Seu marido, Isaque, e seu filho mais velho lhe traziam água em casa. Os dois cuidavam da casa, da louça e das roupas, e apenas o marido cozinhava. As irmãs de Lara moravam em outra aldeia e sua mãe já era falecida. Sua sogra não morava na aldeia Kwatá. Embora eu tenha observado casos em que as mães, as cunhadas e as sogras da parturiente tivessem prestado auxílio, isso ocorria de maneira muito pontual, na preparação da comida e por pouco tempo. De fato, apenas em dois casos as mães ou irmãs auxiliaram durante todo o período do resguardo, lavando até mesmo as roupas da mulher parida e do bebê. Num caso, o marido da parturiente havia falecido pouco antes da criança nascer. Noutro, o jovem casal Itapema e Iberê moravam na casa dos pais dela. Nos demais casos, os maridos e os filhos mais velhos é que auxiliavam, 
lavando louças e roupas, cozinhando, trazendo água, varrendo a casa e cuidando das crianças menores.

No quarto dia após o parto Lara continuava dentro de casa, com poucas janelas abertas, tendo almoçado um peixe cozido, cará, preparado por seu marido. Antes de ir visitá-la novamente, pensei em presenteá-la com castanhas. Quando comentei com Ceci e Araci que levaria castanhas para Lara, ambas me alertaram que mulher parida não podia comer castanha. Então, levei mangas. Ao entregar as mangas para Lara, ela sorriu, agradeceu e explicou que não comeria porque eram azedas e poderiam causar diarreia no bebê. Seus filhos aceitaram as mangas. Então, ela disse que mulher parida só podia comer "comida escolhida mesmo". Em seguida, passamos a falar sobre esse conhecimento munduruku acerca da alimentação da mulher puérpera. A lista de alimentos que organizei com Lara incluía aqueles permitidos e aqueles proibidos. A dieta de mulher parida era marcada pela restrição a uma série de espécies animais, vegetais e frutíferas. As mulheres que acompanhei cumpriram as restrições alimentares, pois, ao procederem assim, preveniam enfermidades na criança e garantiam sua própria saúde. Conforme explicou Lara, evitam-se determinadas comidas porque "fazem mal para a mulher e para a criança porque vai para o leite".

Um dia antes de visitar Nora e Batista, também no terceiro dia após o parto, vimos Batista descendo em direção ao rio com uma bacia cheia de roupas, no início da manhã. Ele apoiou a bacia exatamente como as mulheres costumavam fazer, sobre a cabeça. Na volta de nossa caminhada, as roupas estavam estendidas no varal. No dia seguinte, fomos fazer uma visita ao casal, que havia tido o terceiro filho. Os outros dois ainda eram crianças pequenas, o mais novo com pouco mais de 1 ano e o outro com 3. Nora estava deitada na rede, na sala, e o recém-nascido estava na rede do quarto do casal quando chegamos. Batista estava cozinhando "galinha do terreiro", doada pela mãe de Nora. Eles nos receberam na sala e conversamos sobre muitos assuntos, desde o trabalho de Batista na igreja católica até o resguardo. Estávamos na época de manga e havia muitas mangueiras na aldeia Kwatá, então perguntei se ela podia comê-la. Nora respondeu que não podia comer nenhuma fruta, que a "dieta da mãe é só galinha mesmo". Do mesmo modo que Lara, Nora também estava se banhando dentro de casa. Explicou-me que a mãe e o bebê não sairiam de casa por oito dias para evitar pegar "vento". Note-se que as doenças do ar vêm com o vento, segundo o que me explicara Araci, sogra de Nora, em outro momento.

De todas as consequências da ingestão de um alimento inadequado, a pior para a saúde da mulher era o risco de hemorragias, de "arriar o sangue". Por exemplo, ela não podia comer porco criado em casa, pois "pode dar sangramento e até matar a mulher". Ao longo de nossa listagem, Lara insistiu que a mulher parida "só pode comer comida fina mesmo". Assim como o porco doméstico, a carne de 
caça de veado também podia provocar hemorragia na mulher. Derivados da farinha como, por exemplo, tapioca e biju, causavam "frio no útero", conforme outras mulheres haviam comentado. "Peixe liso não presta", sintetizou Lara. Além disso, a alimentação da mãe também repercutia diretamente no bem-estar da criança que mamava no peito, pois, como salientou Lara, "vai para o leite". Por esse motivo, frutas consideradas azedas como manga, laranja, tangerina, abacaxi, jambu, entre outras, podiam causar diarreia no bebê. Os alimentos considerados gordurosos como a castanha e algumas espécies de peixe também podiam provocar diarreia e fazer o bebê "cagar verde". Os Munduruku já viram bebês e crianças com diarreia perderem muito peso em pouco tempo e sabiam que, em estado grave, podiam vir a falecer. Embora a diarreia fosse também sintoma de outras doenças sérias como o quebranto, que podia ser causado por qualquer pessoa, inclusive os pais, e cujo tratamento consistia em benzer, aqui me interessa destacar a restrição alimentar seguida pela mãe com o objetivo de manter a saúde de seu filho recém-nascido, além da própria saúde. Isto é, sublinhar que, do ponto de vista dos Munduruku, a dieta da mãe interfere diretamente na saúde do recém-nascido.

A seguir, apresento a lista dos alimentos permitidos e proibidos e os motivos da proibição. Esta lista foi iniciada a partir das conversas com Lara, durante seu resguardo, e complementada por mim com base na observação e na conversa com outras mulheres paridas.

Quadro 1 - Dieta alimentar da puérpera

\begin{tabular}{|c|c|c|}
\hline Pode comer & Não pode comer & Motivo da restrição \\
\hline Cará branco & Piranha - até o $5^{\circ}$ mês & Come de tudo \\
\hline Jaraqui de escama grossa & Pirarucu & \\
\hline Tucunaré & Tambaqui & \\
\hline Cará manduca & Sulamba & \\
\hline Traíra & Jaraqui de escama fina & \\
\hline Pescada & Peixe liso & Não presta \\
\hline Galinha do terreiro & Jacundá & \\
\hline Galinha comprada & Porco doméstico & Pode dar hemorragia \\
\hline Boi & Porco queixada & Faz mal \\
\hline Jabá & Paca & Criança não dorme \\
\hline Porco do mato caititu & Anta & \\
\hline Galinha do mato - nambu & Veado & Pode dar hemorragia \\
\hline Paca & Patas de cutia & O filho fica fujão \\
\hline Veado vermelho grande & Castanha - por causa do óleo & $\begin{array}{l}\text { Hemorragia na mulher, diarreia na } \\
\text { criança }\end{array}$ \\
\hline
\end{tabular}


Quadro 1 - Dieta alimentar da puérpera (cont.)

\begin{tabular}{|c|c|c|}
\hline Pode comer & Não pode comer & Motivo da restrição \\
\hline Cutia (menos patas) & Manga & Pode provocar diarreia no bebê \\
\hline Melancia & Laranja & Idem \\
\hline Tucumã & Tangerina & Idem \\
\hline Banana grande & Abacaxi & Idem \\
\hline Banana comum & Jambu & Idem \\
\hline Caju & Frutas azedas & Idem \\
\hline Macaxeira & Melancia & Fria \\
\hline Cará & Tapioca & Dá frio no útero \\
\hline Macarrão & Biju & Idem \\
\hline Chá de sucuuba - para desinflamar & Jabuti & \\
\hline Chá de taperebá - para desinflamar & Tracajá & \\
\hline
\end{tabular}

Ao apresentar essa lista, não pretendo investigar a lógica simbólica subjacente à classificação dos alimentos, pois considero que as distintas classificações de alimentos são operadas conforme a situação de quem consome, o contexto do consumo, o modo de preparo, ainda de acordo com as características e as qualidades dos alimentos em si (Maués G Motta-Maués, 1978). É notável que, nas avaliações feitas pelos Munduruku sobre os alimentos proibidos na dieta de mulher parida, eles ponderem, além das características do alimento em si (peixe de escama fina ou sem escama), também sobre o comportamento do animal (piranha "come de tudo", paca "acorda cedo"), sobre a origem do alimento (doméstica ou selvagem), e, ainda, evidentemente, sobre o estado de quem consome: a mulher de resguardo. Fora do período do resguardo, não estando a pessoa em convalescença ou em tratamento para alguma enfermidade específica, qualquer alimento pode ser apreciado ao gosto particular de cada um, sendo, assim, permitido. Ademais, a lista acima não é exaustiva e pode ser alterada com o passar dos dias de resguardo. O que é considerado proibido varia de acordo com a pessoa entrevistada. Lara, por exemplo, relatou que sua mãe não comia peixe nos primeiros dias após o parto, apenas carne de caça trazida pelo pai. Araci, que partejou muitas outras mulheres de sua família extensa, "pegava barriga", "puxava a mãe do corpo", ensinava que a alimentação no resguardo do primeiro filho era muito importante porque definiria o que a mulher poderia comer nos próximos resguardos. Segundo Araci, "se comer outra coisa diferente, dá hemorragia". Além disso, ouvi diferentes avaliações: ao passo que uma mulher afirmou que "cutia era comida preferida de mulher parida", em outra aldeia uma mulher me disse que "cutia não presta". Enfim, é mais apropriado alegar o caráter dinâmico, diverso e até idiossincrático do sistema alimentar 
da mulher parida. Isso posto, é também oportuno salientar o investimento coletivo na manutenção e propagação desse sistema alimentar ao longo das gerações como saberes munduruku acerca das práticas de autoatenção à saúde.

É importante destacar que as restrições implicam sentimentos de impotência e falta de controle sobre a alimentação ideal, compartilhados pelas mulheres que estavam cumprindo o resguardo antes de retornarem às respectivas aldeias e foram entrevistadas na Casa de Apoio à Saúde do Índio (Casai).

Itapema teve seu parto na cidade, acompanhada de sua mãe, em março de 2011. Comentou que "na Casai é ruim de comida", por isso "tem que levar dinheiro de casa". Todavia, o dinheiro não foi suficiente, pois sua mãe teve que "pedir pra outros doar um pouco de galinha". Além disso, "não tinha farinha". Todas as mulheres paridas com as quais conversei na Casai reclamavam da comida. Não só da qualidade, mas da rotineira falta de comida adequada - conforme desabafou seu administrador em uma reunião da União dos Povos Indígenas Munduruku e Sateré-Mawé (Upims) realizada na aldeia Aru em maio de 2011, "alimentação vem, mas não é suficiente, dura só vinte dias". Os sentimentos de impotência e descontrole sobre a alimentação são compreensíveis, uma vez que na aldeia se conhecia a origem do alimento, "galinha do terreiro", e a fonte provedora, que era o marido da mulher parida, o qual também se responsabilizava por seu cozimento. Então, podemos inferir que havia um controle de qualidade munduruku sobre a produção e o consumo de alimentos. Por outro lado, na cidade, na Casai, desconhecia-se a origem do alimento. Sem falar na inadequação do cardápio ao estado liminar do resguardo de parto. Na Casai "não se sabe o que se está comendo".

Após voltar para a aldeia Kwatá, Itapema, seu esposo e o recém-nascido foram morar com os pais dela, na casa ao lado de onde eu estava morando. Embora as mulheres e os homens Munduruku tenham me dito que a mulher parida e a criança deviam ficar oito dias dentro de casa, observei que de fato elas permaneciam muito mais tempo. As janelas da casa de Lara foram reabertas somente no décimo primeiro dia após o parto. Além de seguir sua dieta de mulher parida, "só cará branco e tucunaré cozido", ela e seu bebê ainda se banhavam dentro de casa, enquanto seu marido continuava a fazer todos os serviços domésticos, como lavar louças, roupas e cozinhar. Passados 13 dias do parto, Lara passou a lavar as louças, porém ainda dentro de casa, com água trazida do rio, carregada por seu marido. Itapema saiu de dentro de casa pela primeira vez dez dias após o parto. Embora ela e seu bebê passassem boa parte do dia na cozinha, um espaço coberto mas aberto nas laterais, Itapema não pôs os pés fora de casa antes disso. No décimo dia, ela saiu de casa à noite junto com seu marido e uma vizinha e sentaram-se em um banco construído na lateral da casa. O bebê estava dormindo. Ela ficou ali alguns minutos e voltou para dentro da cozinha, de onde continuou a conversar. Alguns dias depois, Rita, mãe de Itapema, apareceu na casa de Ceci e aproveitou para 
perguntar para Ceci se Itapema já podia ir "para a beira", isto é, até o rio. Estávamos na cozinha preparando o almoço e Ceci perguntou há quanto tempo Itapema estava de resguardo e Rita respondeu que fazia vinte dias. Em seguida, Ceci disse: "Sim, ela pode ir para a beira, mas deve ser rápido, não é pra ela ficar lá pela beira porque ela ainda tá ferida por dentro".

Após Rita ir embora, perguntei para Ceci por que Itapema não podia se demorar na beira. Ceci respondeu de forma muito direta: "Porque o boto pode se agradar dela e também tem a cobra d'água, Morecúb, que se vinga da mulher menstruada e de resguardo". Perguntei, então, como a cobra se vinga. E ela respondeu: "Emprenhando a mulher". Perguntei o que nascia caso a mulher fosse emprenhada pela Morecúb. Ceci disse que nascia com cabeça de criança e corpo de cobra. Perguntei, então, se isso já havia acontecido. Ceci lembrou que sim e contou um caso de filha de Munduruku com kakerewat. A finada Cecília, certa vez, começou a sonhar e a conversar muito no sonho. Seu marido até estranhou e lhe perguntou por que e com quem ela conversava tanto enquanto dormia. Cecília disse que era um homem. O tempo passou e ela continuou a sonhar com aquele "homem que perseguia ela", até que "ela se agradou dele". Desse agrado nasceu Tereza. O homem que perseguia Cecília era um kakerewat. Os kakerewat moram na "terra preta", no mundo subterrâneo, são seres pequenos e de pele escura. Ceci disse que Tereza teve uma filha muito bonita, uma mulata com cabelos enrolados. Ceci contou, em seguida, que sua sobrinha Margarida foi morar com o marido perto de onde tinha terra preta. Todo dia, ao entardecer, seu marido saía para fachear e Margarida ficava sozinha. Uma vez, ela estava menstruada e escutou um "assopro de mão", disse Ceci, "igualzinho ao que a gente faz para assobiar". Ela passou a escutar esse assopro todo dia, quando seu marido ia fachear. Até que, certa vez, o escutou bem próximo da casa. Quando seu marido retornou, Margarida contou para ele e disse que não iria mais morar lá. Eles acabaram se mudando para a aldeia Kwatá. Nos dias seguintes à pergunta de Rita, não vi Itapema descer até a beira, mas a vi estendendo as roupas que sua irmã havia lavado no terreno ao redor da casa.

A reclusão no resguardo do parto é uma prática de autoatenção que incide sobre a mãe e o bebê, delimitando um conjunto de atividades e os espaços de circulação a partir dos saberes cosmográficos que sintetizam a possibilidade e a existência de relações entre humanos e seres encantados, que resultam em prejuízos para os humanos. Assim, a reclusão do resguardo constrói uma distinção entre pessoas em um estado específico, mãe e bebê, caracterizado por uma condição de maior vulnerabilidade, e pessoas saudáveis, o pai, os demais filhos, a sogra, a mãe, a irmã etc. Essa distinção, por sua vez, se replica através da tênue linha que separa os humanos dos demais seres que habitam o cosmo.

No caso da reclusão do bebê, vimos que se pretendia evitar doenças vindas pelo ar ou ainda por quebranto. Os Munduruku identificaram dois tipos 
de quebranto: aquele resultante de agrado ou admiração, quando uma pessoa fica olhando e admirando uma criança, e o quebranto de fome, quando o pai volta para casa, após suas atividades, e pega a criança no colo sem ter se alimentado antes. Em ambos os casos, os sintomas são diarreia, febre e vômito, e o tratamento consiste em benzer a criança e fazer defumação. Os Munduruku conheciam medidas preventivas para evitar o quebranto. Algumas famílias fabricavam pulseiras com uma pequena bolsa para colocar um pedaço de alho, colares com dentes de macaco-prego ou com dentes de capivara. Outra ação preventiva era feita pelo pai que, ao retornar da roça, da pescaria ou da caçada, deveria retirar a camisa suada, virá-la do avesso e jogá-la sobre a criança.

A reclusão da mulher parida, por sua vez, além da restrição relativa aos espaços de circulação, abrangia uma restrição a atividades diárias. No pós-parto, as mulheres Munduruku permaneciam dentro de casa, onde tomavam banho, dedicando seu tempo aos cuidados corriqueiros com o recém-nascido, e nada além disso, por determinado período. Conforme disse, embora os Munduruku indicassem que se tratava de um período de oito dias, de fato as mulheres permaneciam dentro de casa por mais tempo. Observei que a partir do décimo dia já retomavam algumas atividades características do gênero feminino, como lavar louças, mas ainda no interior da casa. Naná também permaneceu dentro de casa dez dias após o parto e não ia para a beira. Com 22 dias de pós-parto, ela ainda permanecia a maior parte do tempo dentro de casa. Já saía, mas sua circulação se restringia ao terreno ao redor de casa. Antes de parir, Naná costumava frequentar a casa de sua vizinha Rita. Numa tarde, estávamos várias mulheres e crianças conversando na cozinha de Rita, como costumávamos fazer. Dali podíamos ver Naná sentada na sala de sua casa, com seu filho mais novo e o recém-nascido. Naná não veio para a conversa. Ao contrário, as filhas de Rita é que foram até a casa de Naná. Ela estava com 28 dias de pós-parto. Na aldeia Niterói, Vani, apesar de já sair de dentro de casa e ultrapassar o espaço do entorno da casa, não ia para a beira aos 25 dias de pós-parto. Gigi, na aldeia Kwatá, tomou seu primeiro banho na beira passados quarenta dias do parto. Estávamos em sua casa, ela morava com a mãe, Margarida. Margarida era agente indígena de saúde (AIS) e ao ver Gigi se preparando para ir tomar banho na beira, afirmou: "Ela tá quarentando hoje, hoje já sai do perigo".

Não posso afirmar que toda mulher parida Munduruku que acompanhei esperou quarenta dias para ir até a beira. Todavia, posso afirmar que entre os casais que observei em resguardo de parto, com exceção de dois casos, a participação dos maridos e filhos(as) mais velhos(as) foi central para o cumprimento da reclusão. Foi o marido de Naná que carregou água para casa, lavou roupas e louças, cozinhou e cuidou dos filhos pequenos, o menino com 2 anos e a menina com pouco mais de 3 anos, na hora do banho. Embora Lara tivesse um filho de 
11 anos que ajudou muito o seu marido a lavar roupas, louças e cozinhar, foi o pai do recém-nascido que assumiu essas atividades. No resguardo do parto, os homens assumiram as atividades que suas esposas realizavam no dia a dia, conforme descrito no Capítulo 2.

Sob essa ótica, o resguardo do pós-parto é um estado liminar no qual ocorrem algumas inversões. O contraponto dessas inversões estava nas relações sociais da vida cotidiana de produção, distribuição e consumo de alimentos, nos espaços de circulação das mulheres e homens e nas atividades diárias que eles/elas realizavam. Se costumeiramente as mulheres lavavam roupa, cozinhavam e cuidavam das crianças na hora do banho e da casa, agora eram os maridos que faziam esses trabalhos. Já vimos que no resguardo do parto e durante a menstruação, as mulheres Munduruku delimitaram seus espaços de circulação, pois a beira era um lugar perigoso. Registramos, também, a existência de uma dieta alimentar restrita, que deve ser seguida pela mulher parida. Assim, a reclusão da mulher parida só foi possível porque seu marido cooperou ativamente, auxiliando a família nos cuidados com a casa, as roupas, as louças, os filhos menores e a cozinha. É possível sugerir que se algo transpassa a rotina e o estado liminar do resguardo do parto é esta relação de cooperação entre homem e mulher conjugando seus esforços para manter o bem-estar dos membros da família elementar e extensa, além da saúde da própria mulher e do recém-nascido.

Não apenas a mulher parida ou menstruada pode sofrer as consequências do descumprimento do resguardo relativo a cada uma dessas condições, conforme descrito aqui. Do ponto de vista dos Munduruku, todo aquele que passar pelo rastro dessas mulheres pode vir a sofrer infortúnios, doenças e até morrer. Certa vez, quando fui à casa de Lara passar algumas horas durante seu resguardo de parto, ao saber que eu iria conhecer o curador Ubirajara ela me contou que ele já havia tratado um de seus filhos. O menino só chorava, "ficava espantado, com medo, e sentia dor de cabeça". Ela chegou ao diagnóstico junto com o AIS que estava fazendo a visita domiciliar: "era mau-olhado de boto que flecha as crianças". O próprio AIS foi quem indicou Ubirajara, pois naquela época não havia curador na aldeia Kwatá, e a levou até ele.72 O curador confirmou o diagnóstico da mãe e do AIS e disse que a causa fora o fato de o menino ter andado pelo rastro por onde uma mulher menstruada havia passado. Em capítulos anteriores, sugeri que a mulher parida ou menstruada estaria vulnerável a uma aproximação com os seres encantados. Esse caso do filho de Lara permite inferir que a vulnerabilidade das mulheres nessas condições pode afetar outras pessoas. Assim, a reclusão seria uma tentativa de controlar essa situação de vulnerabilidade, e poderíamos dizer que se trata de uma política da minimização do perigo. Aliás, qualquer Munduruku está sujeito a esse perigo, que não depende exclusivamente da situação de vulnerabilidade até agora descrita: independentemente dessa situação específica, qualquer homem, mulher, 
criança, jovem ou velho(a) Munduruku poderia se envolver com seres encantados caso frequentasse a beira nos horários das 6 da tarde ou ao meio-dia, expondo-se ao risco do contato com botos malignos.

Nas práticas de autoatenção ao resguardo do pós-parto como modo de produção do corpo e política de minimização do perigo, destaca-se a importância da dieta alimentar nos cuidados maternos com o recém-nascido. Para os Munduruku, o aleitamento materno era central para o crescimento do bebê após o nascimento, quando focalizavam as práticas alimentares. Além disso, os Munduruku também faziam fricções (massagens), defumações, ministravam remédios do mato, entre outras práticas, durante o desenvolvimento da criança, principalmente com os adolescentes, no intento de formar seu corpo e suas características morais. Vi mulheres amamentando filhos com mais de 3 anos. O leite materno, segundo os Munduruku, é composto pelos alimentos ingeridos pela mãe, e por isso é preciso estar atento aos alimentos consumidos. Nem toda mulher tinha facilidade em amamentar ou teve leite logo após o parto. Para estimular a produção de leite, entretanto, não bastava às mulheres Munduruku alimentar-se. Elas conheciam algumas práticas de manipulação do seio, como, por exemplo, passar uma trouxinha de sal no mamilo em movimentos repetidos de cima para baixo, por alguns instantes, e depois enterrá-la na beira, a fim de estimular a produção de leite. Indicavam também esquentar pouca água em uma panela e passar o vapor condensado na tampa no seio. Da mesma forma, indicavam práticas para fazer cessar o leite.

É possível traçar um paralelo entre essa prática de autoatenção e a prática biomédica de incentivo ao aleitamento materno. Em consonância com as recomendações da Organização Mundial da Saúde (OMS), o Ministério da Saúde brasileiro recomenda o "aleitamento materno exclusivo por seis meses e complementado até os dois anos ou mais" (Brasil, 2009: 12), destacando entre os efeitos positivos dessa prática os aspectos nutritivos e afetivos necessários ao desenvolvimento da criança e à saúde da mãe. Podemos sinalizar, mais uma vez, que na tentativa de minimizar risco ou prevenir enfermidades, as mães Munduruku selecionaram os alimentos apropriados para o período do resguardo. Entretanto, as pesquisas científicas de caráter biomédico, que fornecem as evidências que fundamentam as recomendações do Ministério da Saúde, definem a qualidade dos alimentos por meio de técnicas que avaliam o aspecto nutricional com base nas propriedades químicas e orgânicas e nas condições microbiológicas dos alimentos. Os Munduruku, por sua vez, além de considerarem os aspectos nutricionais dos alimentos - como gorduroso ou azedo -, também avaliavam sua origem (doméstica ou selvagem) e, no caso de carnes, o comportamento e as características do animal.

O período do resguardo de parto variou de 40 a 45 dias para a maioria das mulheres. Entretanto, alguns itens da dieta alimentar ultrapassaram o período da quarentena. Piranha devia ser evitada por cinco meses após o parto, pois "come de 
tudo". As mulheres me explicaram que após quarenta dias já podiam comer quase de tudo. Entretanto, as restrições alimentares da mãe iam paulatinamente perdendo a importância conforme os alimentos eram inseridos na dieta do bebê. Em geral, seguiam as recomendações da EMSI de amamentar exclusivamente até os 6 meses de vida. De modo semelhante, a reclusão da mulher parida também não tinha data certa para se encerrar. Os Munduruku citaram um período de oito dias, porém vi mulheres permanecendo por mais tempo no interior da casa. O banho no rio, na beira, fora retomado apenas alguns dias após o sangramento cessar, entre vinte dias ou mais depois do parto. Em alguns casos, as mulheres permaneciam a quarentena toda sem se banhar no rio, embora já circulassem por um amplo espaço além do entorno da casa. Conforme sublinhei, durante todo o período do resguardo de parto foi notável a participação dos companheiros, maridos dessas mulheres e pais dos recém-nascidos.

\section{O taperebá e o "pai da criança"}

De certa forma, os pais também cumpriram resguardo. Os Munduruku costumavam dizer que o pai do recém-nascido não podia fazer força. Itamar foi quem primeiro especificou as atividades que o pai do recém-nascido devia evitar: "não pode flechar, dar partida no motor, atirar de espingarda, não pode fazer força que sai sangue do umbigo da criança". Em certo sentido, isso era o mesmo que dizer: não pode fachear, não pode pescar, não pode caçar. Os homens Munduruku utilizavam a zagaia, espécie de flecha para fachear, uma técnica de pesca. Para pescar, teriam de remar a rabeta, ao invés de se deslocar de forma motorizada, o que aumenta o tempo de navegação e reduz a distância a ser percorrida. E para caçar, utilizavam arma de fogo, espingarda. Ainda segundo os Munduruku, os homens não podiam dar nó em corda, pilar, trançar ou tecer o que quer que fosse durante oito dias. O principal motivo era o bem-estar do recém-nascido, "pra criança não se espremer". Ao se "espremer", a criança poderia sangrar pelo umbigo, ao ponto de sofrer uma séria hemorragia. Desse modo, o cumprimento das interdições e proibições do resguardo de parto para os homens Munduruku estava diretamente relacionado com a saúde e a vida do recém-nascido, e não com a própria saúde ou com a saúde da mulher, como acontecia em outras etnias indígenas (Da Matta, 1976: 89-90). Logo, o descumprimento do resguardo de parto por parte do pai afetava diretamente a saúde da criança, podendo até mesmo levá-la à morte.

No entanto, os Munduruku afirmavam que havia uma maneira de proceder para evitar que as crianças sofressem com as ações do pai durante o resguardo de parto. Essa ação profilática constituía-se em uma prática de autoatenção relativa ao resguardo do parto que incidia sobre o comportamento e as atividades físicas 
do pai do recém-nascido. O homem Munduruku só podia fazer força durante o resguardo após apresentar ao filho recém-nascido "o pai da criança". Trata-se de um ritual muito particular em que um tronco de árvore é apresentado ao recém-nascido como pai da criança.

O "pai da criança" é o tronco da árvore de taperebá (Spondias mombin). Esse tronco deve ser de um taperebá "da mata", isto é, não pode ser "pai" de outra criança. Por esse motivo, o homem adentra a mata em busca de um taperebá, ao encontrá-lo o corta e leva um pedaço para casa. Ao chegar a casa, aproxima-se da rede do bebê e passa o pau de taperebá ao redor da rede, por cima e por baixo da criança deitada. Ao mesmo tempo que passa o pau de taperebá ao redor do bebê, diz: "Aqui está o teu pai, aqui está teu pai". Assim fazendo, ele está apresentando "o pai da criança". Após "apresentar o pai da criança", conforme disse um AIS que era também conselheiro distrital de saúde e pai de duas crianças, "aí pode fazer quase tudo, que a pessoa do pai fica lá". O "pai da criança" fica no interior da casa, em geral em um canto do quarto onde o recém-nascido permanece boa parte do dia.

Figura 24 - Irmãs mostrando "o pai da criança"

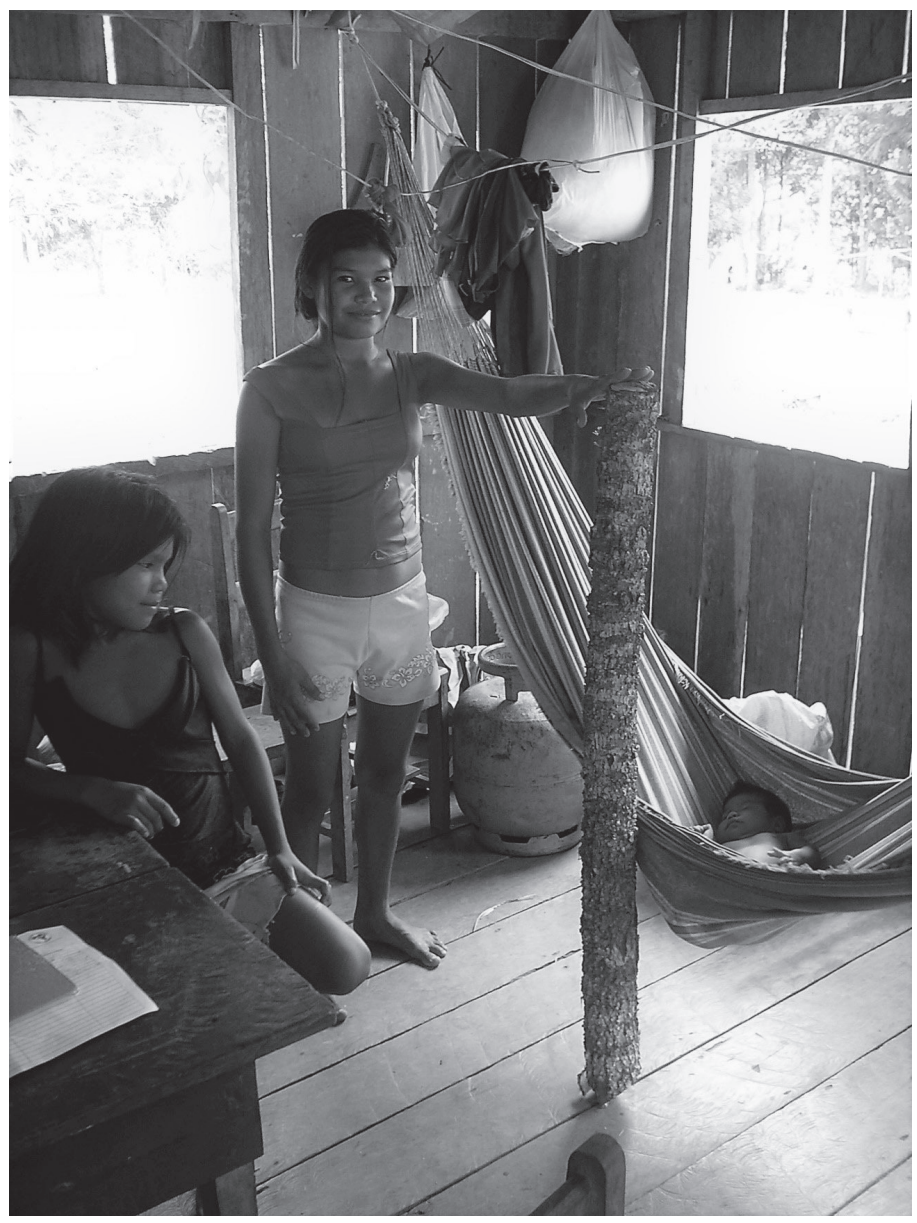

Foto Daniel Scopel.
Figura 25 - Pai mostrando "o pai da criança" que ele cortou para deixar próximo de seu filho recém-nascido

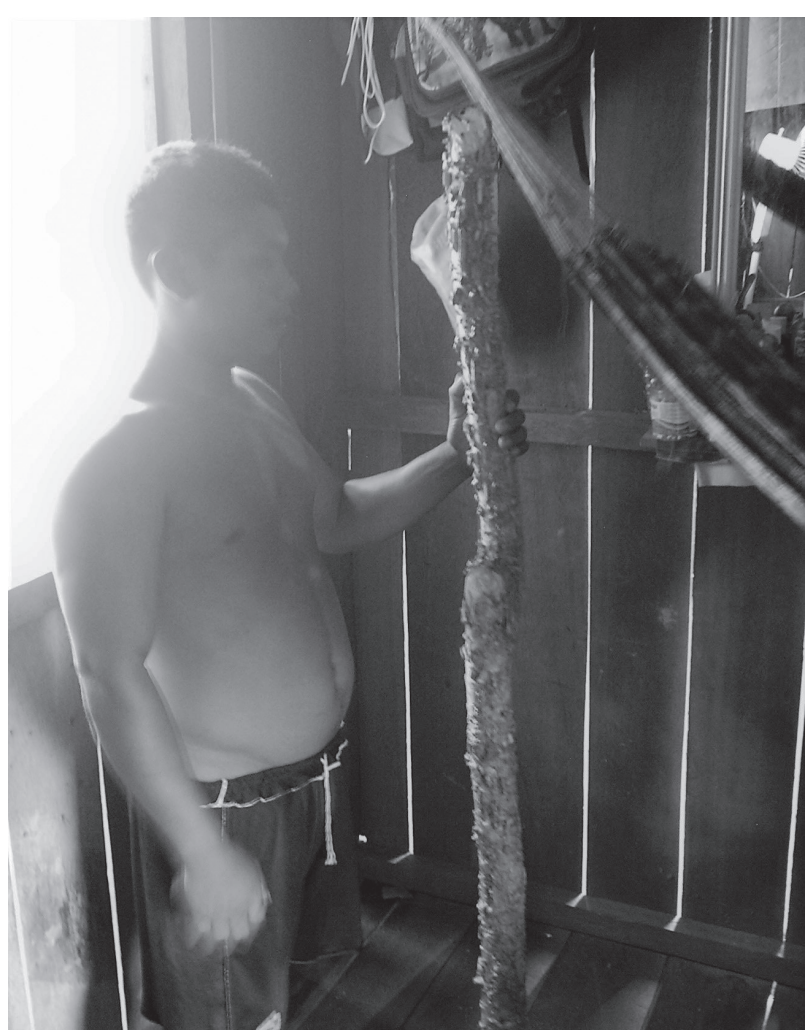

Foto Daniel Scopel. 
Eu estava na casa do casal Batista e Nora, no terceiro dia do resguardo do parto; quando entrei no quarto para conhecer o recém-nascido, lá no canto estava o "pai da criança". Perguntei por quanto tempo o "pai da criança" permaneceria ali e Batista me disse que "até inteirar 45 dias"; depois "enterra, devolve pra mata".

Quando fui visitar Naná, dez dias após o parto, perguntei a ela se eles haviam feito o "pau de taperebá". Ela respondeu-me que sim, que "estava passando no umbigo do bebê". Naquele momento, percebi que eu não havia feito a pergunta corretamente, então refiz a pergunta: cadê o pai da criança? Ela sorriu e perguntou se eu queria vê-lo. Eu disse que sim. Levantamos e ela me levou até a cozinha e mostrou o tronco de taperebá que estava na vertical, num canto. Ao mostrá-lo, ela disse que "agora" Moacir já podia fazer quase tudo que não teria nenhum problema. Isso explicava por que o vi capinando ao redor da casa, atividade que as mulheres costumavam fazer. Moacir e Naná eram nossos vizinhos. Da varanda da casa de Ceci podíamos ver a sala da casa deles. O casal compartilhava a mesma porção da beira que a família de Iara e Carlos, cuidadores de Ceci. Era a mesma porção da beira onde eu e meu esposo também nos banhávamos, lavávamos nossas roupas e louças. Durante a reclusão de Naná, foi Moacir quem lavou as roupas, louças e deu banho nos filhos pequenos. Lembro que, ao vê-lo descer para a beira com uma bacia cheia de roupas, seu vizinho fez um comentário entre risos sobre o fato de Moacir estar lavando roupas. Essa brincadeira soou como um misto de jocosidade e de felicitação por mais um filho entre dois homens que pertenciam à mesma família extensa, moravam no mesmo segmento residencial, jogavam no mesmo time de futebol, compartilhavam horas de conversa e, eventualmente, bebiam juntos. Contudo, mesmo tendo apresentado o "pai da criança" para seu filho recém-nascido, Moacir parou de trabalhar na construção da escola nova que estava sendo erguida na aldeia Kwatá. Não perguntei a ele a razão de não mais trabalhar na construção, pois era óbvio que se tratava de cumprir o resguardo do parto, seja porque devia evitar fazer força, seja porque estivesse absorvido por outros trabalhos, antes realizados por sua esposa, além daqueles de sua competência diária, como pescar.

Mesmo após apresentar o "pai da criança", alguns pais mantiveram uma atitude comedida durante, aproximadamente, oito dias após o parto, evitando jogar futebol ao fim do dia e nos fins de semana, ou atividades que ocupassem o seu dia, exigindo muito esforço, como trabalhar na construção da escola ou na empreiteira responsável pela implantação da rede de energia elétrica. Eles solicitavam a outros homens ajuda para essas atividades proibidas.

Houve, no entanto, casos em que os pais não apresentaram o "pai da criança" para o recém-nascido. O marido de Lara, Isaque, não o fez. Embora tenha acatado as prescrições relativas às práticas de autoatenção ao pós-parto, como executar as tarefas notoriamente realizadas pelas mulheres na vida cotidiana, Isaque deliberadamente não cumpriu a prescrição de "apresentar o pai da criança" nem 
deixou de trabalhar. Ele era o responsável pela energia elétrica na aldeia Kwatá movida a diesel. O trabalho incluía abastecer o gerador com combustível, ligar seu motor e reparar a fiação elétrica. Quando fui visitá-la no quarto dia após o parto, Lara contou, com grande preocupação, que seu filho sangrara no dia anterior. Isaque, seu marido, foi chamado para retirar a fiação elétrica dos postes da rua onde haviam sido cortadas castanheiras e depois colocá-la de volta. Ele acabou por "desenrolar os fios" para prendê-los novamente aos postes. Lara disse que, por esse motivo, "o umbigo da criança sangrou". Ela estancou o sangue com um "remédio do mato", "queimou" o umbigo com "copaíba para parar de sangrar". Oito dias após esse evento, quando perguntei como estava o bebê, Lara disse que estava bem e que seu marido Isaque vinha "se resguardando", pois tinha passado a evitar algumas atividades como "pregar e trançar fio de luz".

Outro caso semelhante ocorreu em uma aldeia no rio Mari-Mari, na TIKL. Infelizmente, o desfecho desse caso foi a morte do recém-nascido três dias após o parto. Durante a primeira etapa do trabalho de campo, meu esposo e eu fomos conhecer algumas aldeias do rio Mari-Mari a convite do conselheiro distrital de saúde Munduruku que representava as aldeias daquele rio. Passamos apenas sete dias na casa dele, porém, com a chegada da notícia da gravidez de sua mulher, confirmada pelo exame de BCG entregue pela EMSI no dia de consulta na aldeia onde moravam, muita conversa rolou. Foi sua esposa quem nos relatou o acontecimento. Uma comadre da aldeia Mucajá não conseguiu salvar seu filho, apesar dos esforços. O pai "desobedeceu" ao alerta de sua mãe, a avó da criança, de que "não prestava cortar fio de luz durante os oito dias" após o parto. Porém, o pai teria dito "não dá nada" e seguiu com seu trabalho. Poucos minutos depois de cortar o fio de luz, a mãe do recém-nascido começou a gritar dentro de casa porque estava saindo sangue pelo umbigo do bebê. Ela teria tentado amarrar com um fio o umbigo, mas isso não foi suficiente para estancar e fazer cessar o sangramento, pois o umbigo teria enchido novamente e voltado a "vazar". O bebê teria morrido em consequência do sangramento.

Outros casos sobre a quebra do resguardo do parto foram relatados. Nem todos resultaram em morte, mas todos tiveram como consequência o sangramento pelo umbigo. Rosária, parteira, mãe de muitos filhos, alguns já adultos, outros ainda adolescentes, contou que uma de suas filhas "quase morreu". Ela viu sua filha se espremer quando o marido começou a pilar café. Por sorte, ele estava pilando no lado de fora da casa e ouviu Rosária adverti-lo. Imediatamente parou, mesmo assim a criança sangrou um pouco pelo umbigo.

O curioso nesses exemplos sobre a quebra do resguardo de parto é que eles confirmavam o saber compartilhado por gerações sobre o propósito das práticas de autoatenção seguidas pelo pai, a saúde do bebê. Ao investigar o caso tupinambá, Métraux (1979: 95) sintetizou uma hipótese que ainda hoje cerca o tema 
da couvade. Segundo o autor, o cumprimento da couvade é "uma manifestação simbólica do papel paterno no ato da geração". Belaunde (2006: 234), ao investigar o significado do sangue entre as populações amazônicas de modo geral, sugeriu que "durante a gestação, parto e pós-parto, a dieta e a reclusão são úteis na construção da paternidade responsável do homem com relação ao feto e à mãe".

No tema da couvade, seu cumprimento parece residir entre dois princípios: a afirmação de um laço substancial já dado no momento da fecundação e a afirmação e construção moral do direito de paternidade. Entre os Munduruku, como vimos, há relatos de morte de bebês recém-nascidos devido à falta do pai no cumprimento da couvade. Esta inclui restrições sobre atividades físicas que exigem esforço e prescrições específicas, como "apresentar o pai da criança". Não há uma regra explícita sobre quem deve auxiliar a mulher nesse período do pós-parto; pode ser, conforme me relataram, a sogra, a mãe, a cunhada, um filho ou uma filha. Observei o marido e pai do recém-nascido assumindo as tarefas realizadas pelas mulheres na rotina da vida cotidiana, como lavar roupa, cozinhar e cuidar das crianças. Assim, a couvade munduruku pode ser analisada como a expressão de um discurso explícito e uma prática implícita.

O discurso explícito refere-se ao papel central que os pais têm no bem-estar e na saúde de seus filhos recém-nascidos, e o descumprimento da couvade pode levar à morte. A prática implícita seria a da cooperação entre homem e mulher como valor social central na produção e manutenção da família elementar. Mesmo nos casos em que a couvade não é cumprida, os saberes que os Munduruku compartilham acerca do resguardo de parto são afirmados. Em síntese, os casos de quebra da couvade acabam por reforçar a ideologia do grupo (Young, 1976). Uma ideologia construída e constituidora da cosmografia munduruku, em que determinados lugares e agências assumem sentido e significado particular, específico ao contexto da ação. Lana contou que seu marido não "apresentou o pai da criança" para quatro de seus cinco filhos, tendo-o feito apenas para a criança que nasceu quando moravam na aldeia Kwatá. Durante nove anos o casal morou na cidade de Tefé, pois Jim era funcionário da Fundação Nacional do Índio (Funai). Lá tiveram quatro filhos, e ele não cortou o pau de taperebá porque "era cidade e não tinha taperebá, e também não precisava". Essa explicação define uma restrição geográfica/ambiental indissociável dos saberes cosmográficos, em que estéticas e éticas se adaptam e se modificam, sendo exigidas conforme o espaço de atuação dos atores em sua relação íntima e afetiva com o seu território.

Segundo os Munduruku, o período crítico do resguardo do parto seguido pelos pais é de oito dias. Talvez isso explique por que observei alguns pais deixando de lado certas atividades que faziam comumente, fosse de lazer ou de trabalho, mesmo tendo apresentado "o pai da criança" para o recém-nascido. Após oito dias tudo parece voltar ao normal. Apenas parece, porque, de fato, como vimos, muitas 
mulheres ainda permanecem em reclusão, o que implica diretamente a contrapartida dos homens na execução de uma série de atividades prescritas pelo resguardo do parto. Ao final do resguardo, aproximadamente 45 dias após o parto, os homens enterram "o pai da criança", isto é, devolvem para a terra o pau de taperebá. Não há qualquer cerimônia para isso. Acompanhei um casal plantando o taperebá. Em muitas casas que visitei, comentei sobre essa prática, e homens e mulheres Munduruku apontaram árvores de taperebá no quintal, fazendo a seguinte referência: "Aquele ali é pai de fulano".

Em uma das visitas que fiz ao casal Zazá e Ciro, pude observá-los plantando o taperebá, e foi uma boa surpresa ser convidada para o evento. Zazá já havia escolhido o local para plantá-lo: seria no terreno onde estavam construindo uma nova casa. O terreno havia sido roçado e queimado recentemente, ainda havia vestígios de cinza no chão. Enquanto Ciro plantava, Zazá, com a criança no colo, o exortou a cavar fundo a fim de que desse "bastante frutos". Em seguida me mostraram o "pai" de uma das filhas, na época com 6 anos. Era uma árvore de taperebá já grande, também localizada perto de casa.

Figura 26 - Família acompanhando o pai enquanto enterra "o pai da criança"

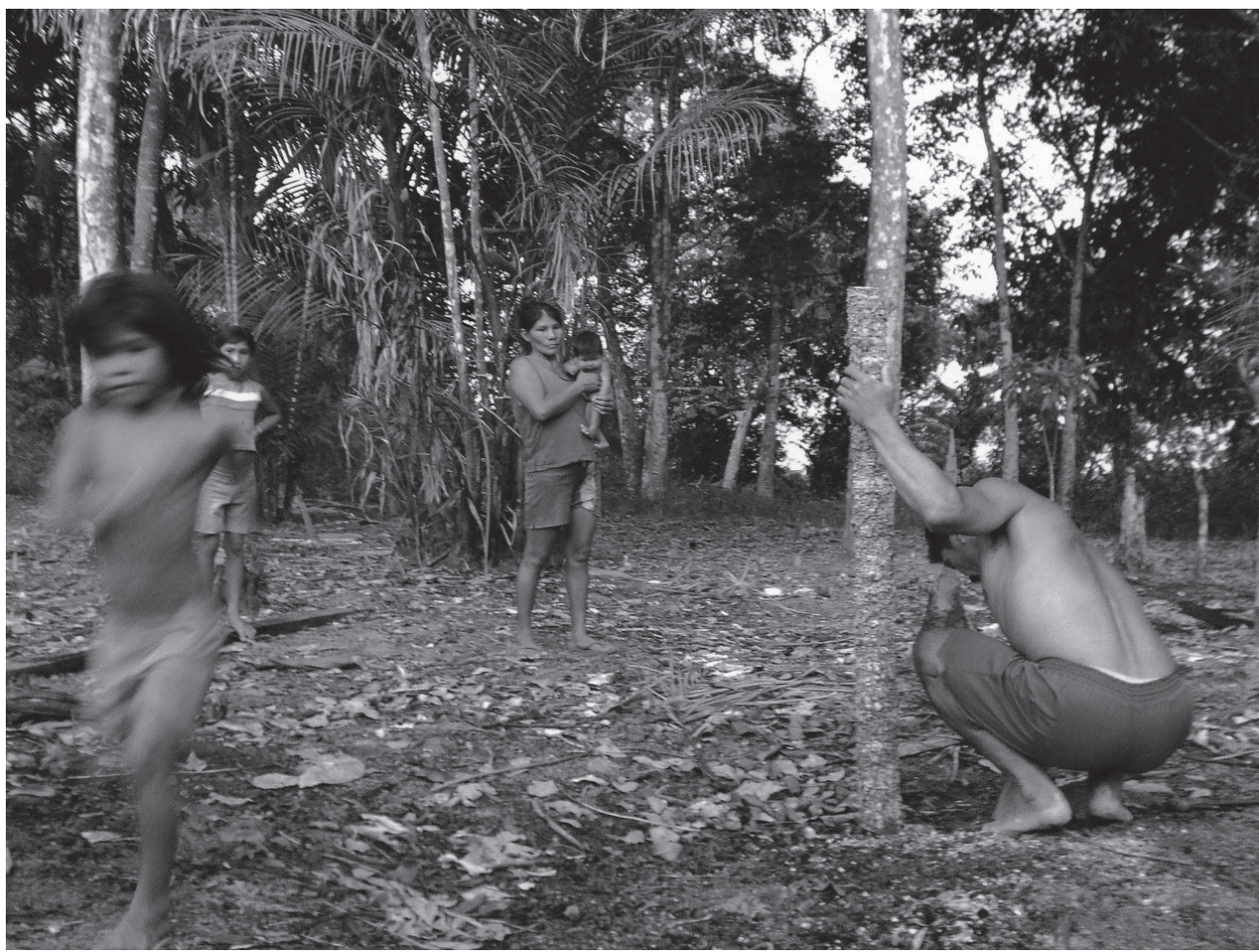

Foto Daniel Scopel. 
"Por que o taperebá?", perguntei para vários homens e mulheres Munduruku, querendo saber se "o pai da criança" podia ser qualquer outra árvore. Todos foram unânimes em salientar as propriedades curativas e a resistência dessa espécie. Zazá, ao ver as fotos do dia da plantação do taperebá da filha caçula, já com 7 meses, explicou-me que "taperebá é um tipo de madeirame em que não se vê ferida, não dá bicho. O taperebá é remédio". Ou, como me explicou um senhor, avô de muitos netos, "nem fogo mata ele, pode revirar com a raiz para cima que ele não morre". Esse mesmo ancião contou-me que "só fogo de raio" o matava. Os Munduruku têm estórias que ressaltam as características perenes e a resistência do taperebá. Há a história de alguém que esquecera de devolver o taperebá para a terra ao final da quarentena. Após anos, a mulher achou o taperebá caído, lá dentro de casa. O galho estava seco, mas não tinha apodrecido. O marido plantou e todos se surpreenderam quando a árvore brotou. ${ }^{73}$

Figura 27 - "Pai da criança" enterrado para crescer, dar frutos e fazer parte da memória familiar

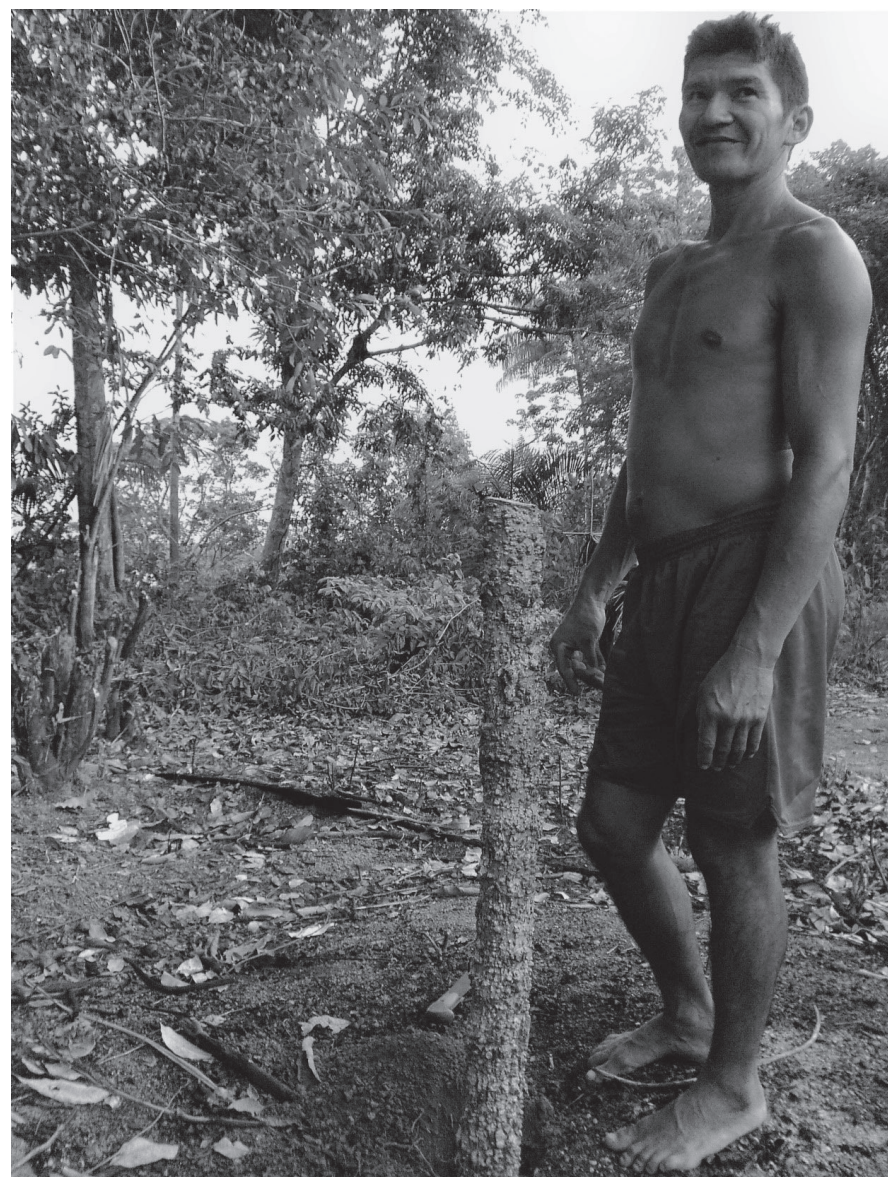

Foto Daniel Scopel 
Além dessas características de grande resistência, resiliência e perenidade, sobressai, ainda, o caráter curativo a que a árvore é associada. A casca do taperebá é usada como remédio caseiro pelas mulheres paridas Munduruku para "sararem por dentro" e também é passado no umbigo das crianças. Entre suas propriedades terapêuticas está a de curar feridas não só da mulher parida. Meu esposo havia sofrido um acidente em campo, machucando a perna. O machucado demorou a sarar e nossa anfitriã, vendo que a ferida continuava apesar dos esforços para tratá-la, indicou a Daniel sumo da casca de taperebá, espremido diretamente sobre o machucado para auxiliar na cicatrização (Scopel, 2013: 223-224). A parteira Gioconda lembrou-se que sua avó dizia que "taperebá era pajé, curador, feiticeiro, antigamente". Ela destacou as propriedades medicinais e curativas do taperebá, "bom para mulher que está de parto e para sarar umbigo". Além do mais, "serve para comer" (os frutos). ${ }^{74}$

\section{A longevidade e a força de uma samaumeira}

Gigi, filha de Margarida, agente indígena de saúde, uma jovem de aproximadamente 17 anos, estava "quarentando" naquele dia. Durante nossa visita, Margarida fez o seguinte comentário: "Hoje ela já sai do perigo". O parto foi no hospital da cidade de Nova Olinda do Norte. Ambas ficaram alojadas na Casai por sete dias após o parto, antes de retornar para a aldeia. Até aquele dia Gigi estava tomando banho dentro de casa para evitar qualquer "perigo", isto é, qualquer doença e mesmo morte em consequência do contato com os seres que habitam o mundo subaquático, em especial o boto. O cheiro do sangue de Gigi, o "sangue do parto", poderia atrair os botos encantados e desencadear uma série de contatos cujas consequências resultariam em "assombração", "endoidar", "ser levada para o fundo" e morte, que não atingiriam apenas ela, mas se estenderiam a toda mulher e criança próxima, como já vimos. Margarida lembrava a Gigi o perigo que todos corriam para incentivá-la a cumprir seu resguardo e a evitar contato com os seres que habitam o mundo subaquático. Ao seguir o resguardo, Gigi intencionava obter força, vitalidade e saúde, a exemplo de sua bisavó centenária, Antônia.

Margarida referia-se à avó, Antônia, como uma samaumeira. Explicou-me que a samaumeira é "uma árvore grande e forte". Antônia era uma pessoa muito admirada pelos Munduruku por seu conhecimento e por tudo o que já vivera. Frequentemente, os Munduruku me recomendavam conhecê-la. Foi Ester, outra senhora de idade avançada, 92 anos, quem me apresentou Antônia. ${ }^{75}$ Era notável o respeito com que os Munduruku se referiam tanto a Antônia como a Ester e as tratavam. Elas eram citadas como grandes conhecedoras da língua, dos costumes, do passado, das histórias e da cultura munduruku. Definitivamente, Ester deu 
grande contribuição a esta pesquisa, pois revelou uma disposição surpreendente para conversar, explicar e contar histórias do "tempo dos antigos", as quais versavam sobre eventos históricos envolvendo os Munduruku e também tratavam de mitos que ela aprendera com os mais velhos. Diariamente compartilhei dúvidas, achados e muitas conversas com ela. Infelizmente, Antônia faleceu durante minha pesquisa de campo.

As mulheres das famílias de Antônia e Ester as admiravam pela saúde que ostentavam, apesar da idade avançada. Eram exemplos de mulheres fortes. Ambas sentiam as consequências do peso da idade, sofriam de catarata, eram hipertensas e não trabalhavam mais na roça. Então, o que seria essa saúde e força a que se referiam as mulheres Munduruku?

Tudo indicava que o crepúsculo da vida não lhes tirara a disposição para conversar e trabalhar, embora não executassem mais as atividades cotidianas das mulheres Munduruku, como cozinhar, cuidar da casa, lavar roupas e louças, capinar a roça e o terreno em volta da casa, cuidar das crianças, entre tantas outras. Outra qualidade reconhecida nessas senhoras era a autonomia para se deslocar, para se alimentar e para cuidar de si, ainda que sempre auxiliadas por outras mulheres mais jovens. A filha que cuidava de Antônia se queixou do fato de a mãe ir tomar banho sozinha na beira do igarapé próximo à casa. Era uma queixa com um misto de espanto e admiração, pois, mesmo com a visão prejudicada pela catarata, Antônia ainda assim saía de casa e punha-se a caminhar em um terreno com declive para chegar até a água. Ester também sempre fazia questão de tomar banho no rio, vencendo os obstáculos do percurso, como troncos de árvores e pedras ao longo do caminho. Muitas vezes fomos tomar banho no mesmo horário, e embora sua filha a auxiliasse no deslocamento, Ester lavava-se e mergulhava sem auxílio algum. Ester ainda se deslocava frequentemente até a igreja nos dias de domingo, sempre acompanhada de seus netos.

Lembro-me do dia em que Ester e eu visitamos Antônia. De fato, a caminhada pela estrada foi muito tranquila e, apesar de lenta, não ofereceu dificuldades para o deslocamento da anciã, que a percorreu todo o tempo sem qualquer apoio, solicitando ajuda apenas para atravessar o terreno entre as casas, principalmente nas partes tomadas pelo mato crescido, o que impossibilitava enxergar os obstáculos. Durante todo o percurso, ela foi apontando as casas e citando seu grau de parentesco com os moradores.

No período do trabalho de campo, Ester sofreu um derrame que a deixou com dificuldades para caminhar sozinha, sobretudo para descer ou subir as escadas de sua casa. Ela precisava de apoio para sair e entrar em casa. Foram longos meses até que se recuperasse das sequelas, e até o último momento do meu trabalho de campo seus familiares continuavam a realizar práticas de autoatenção, executando massagens, puxações e banhos. Sua dificuldade para caminhar aumentou quando iniciaram a construção de uma nova escola em frente à sua casa, pois o 
caminho até o banheiro, localizado a poucos metros de sua casa, estava tomado por restos ou parte dos materiais de construção, como ripas, tijolos, areia etc. Ainda assim, diariamente Ester saía para se reunir com seus familiares na casa de algum parente e sentar-se na rua em frente à sua casa ao fim do dia e conversar. Como dito, Ester já não ia mais à roça nem à casa de farinha, e já não lavava louças e roupas. Todavia, ocupava-se da organização de seu quarto para pôr em ordem suas roupas, seus pertences como fotos, cartas de netos que moravam na cidade de Manaus, entre outros objetos. Ela também estava sempre atenta aos netos e, embora não tivesse a tarefa de cuidar das crianças, exercia a função de orientá-los, vigiá-los e, quando necessário, fazer advertências. À noite, ensinava os netos a falar munduruku. Enfim, Ester e Antônia eram mulheres fortes e sua longevidade vinha acompanhada de saúde, pois não estavam acamadas, não permaneciam deitadas em suas redes ou camas nem dependiam de outra pessoa para levar comida à boca. De certa maneira, Antônia e Ester representavam um ideal de longevidade para as demais mulheres.

No decorrer de muitas conversas, passei a compreender que esse ideal não era visto como fortuna da vida, como questão de sorte, mas sim como consequência das práticas de autoatenção realizadas ao longo da vida de uma mulher. Toda vez que uma mulher Munduruku se referia à força, à saúde e à longevidade, fosse de Antônia, de Ester ou de outras mulheres idosas já falecidas, sublinhavam o cumprimento das prescrições relativas à menstruação, à gravidez e ao pós-parto.

As mulheres que já não estavam mais no período fértil, isto é, que não menstruavam mais, atribuíam sua saúde e força ao fato de terem cumprido seus resguardos. Em geral, essas mulheres tinham aproximadamente 50 anos ou mais, e todas trabalhavam na roça, plantavam, capinavam, colhiam mandioca, faziam farinha, cozinhavam, cuidavam dos filhos e netos, mantinham uma horta com plantas para fazer remédio caseiro (chás, banhos, infusões, pastas etc.) e com condimentos, cuidavam da casa e capinavam o terreno ao redor da casa, colhiam frutas nas proximidades da roça, faziam artesanato e, em alguns casos, trabalhavam também como assalariadas.

Se um dos objetivos do resguardo no pós-parto é evitar o contato com os seres do mundo subaquático, com motivação imediata e pragmática, certamente a intenção de obter longevidade também merece ser destacada. Margarida aprendera com sua avó, Antônia, que uma mulher "não facilitava quando tava na menstruação, não sai mais na porta!". A alimentação incluía somente "comida escolhida quando tava menstruada ou de resguardo". Na gravidez e no pós-parto não se fazia "extravagância, movimento pesado". De modo semelhante, Maria, mãe de 13 filhos(as), contou-me que cumprira todos os seus resguardos de pós-parto. Aos 60 anos, aproximadamente, afirmava com orgulho "por isso que sou uma pessoa forte, porque eu me cuidei muito bem". Maria aprendera com a mãe que a mulher tem de se resguardar para ter boa saúde quando mais velha, referindo-se aos res- 
guardos praticados durante o período menstrual, na gestação e no pós-parto. Ela era uma mulher ativa e realizava todas as atividades cotidianas de cuidados com a casa, com os filhos, com a roça, com seus animais de criação, com sua horta, e ainda costurava, participava no puxirum de seus parentes, fazia remédios, puxações, auxiliava partos, sabia "pegar barriga" e "puxar a mãe do corpo". Enfim, Maria esbanjava força, saber e saúde. Certamente, creio que ela será lembrada pelas mulheres de sua família como uma samaumeira.

O conjunto de prescrições relativas ao curso de vida de uma mulher Munduruku abarca saberes transmitidos ao longo de gerações sobre ações pragmáticas que as auxiliam na fabricação de seu corpo e na manutenção de sua saúde e da saúde e vida dos demais residentes na aldeia. É preciso esclarecer que esses saberes não são herméticos nem esotéricos. De fato, são saberes compartilhados entre mulheres e homens Munduruku.

As práticas munduruku relativas ao resguardo deixam evidente que a autoatenção abrange o coletivo, a família. Nele, as práticas de autoatenção que incidiam sobre o pai tinham o objetivo pragmático de prevenir, em última instância, a morte do filho recém-nascido. Da mesma forma, ao assumir as atividades do trabalho cotidiano da mulher, o pai estava, a um só tempo, cumprindo as práticas de autoatenção ao pós-parto e possibilitando que sua esposa também as cumprisse. E ambos, ao cumprirem as práticas de autoatenção relativas ao resguardo do parto, estavam mutuamente se esforçando por manter e garantir o bem-estar e a saúde do recém-nascido. Ademais, nas práticas de autoatenção relativas à mulher parida evidencia-se com mais clareza que o foco não está apenas no bem-estar da família elementar, mas abrange também a família extensa e os demais membros da aldeia, pois qualquer um poderia passar pelo rastro do cheiro do sangue.

Tais práticas reforçam a ideia processual e relacional de "produção" de pessoas e permitem pensar em uma forma ativa e criativa de construção da continuidade substancial e afetiva entre os pais e entre eles e os filhos (Conklin G Morgan, 1996). O resguardo do pós-parto reforça os laços maritais. Mãe e pai precisam cooperar para manter o bem-estar do filho. O resguardo também reforça uma continuidade entre pai, mãe e filhos, marcada pelo compartilhamento de substâncias em comum - sangue, sêmen e alimento - e mantida por relações de apoio mútuo e autocuidado diários. Em termos sociológicos, o resguardo de parto, ao mesmo tempo que forja uma substancialidade comum pela continuidade de determinadas relações sociais, também reforça a descontinuidade e os distanciamentos necessários para a construção social dos gêneros e para a delimitação das agências humanas e não humanas - nesse caso, pela evitação de certas relações indesejáveis.

Se por um lado o resguardo do pós-parto é um evento restrito à intimidade da família elementar, podendo incluir também a participação de membros da família extensa, por outro as motivações e os riscos envolvidos durante o resguardo do pós-parto constituem parte de um saber compartilhado ao longo de gerações, ocupando 
uma posição central nas preocupações e interesses nativos, pois versam sobre os limites da vida e sobre o perigo iminente da morte. Assim, o resguardo compreende uma ideologia, no sentido de um discurso explícito e coercitivo, e também uma experiência vivida por muitos Munduruku. É preciso, entretanto, ter em mente que, na condução da vida diária, as ideologias são sempre "residuais" e "emergentes" (Ortner, 2006: 5), isto é, na práxis cotidiana os atores sociais agem de maneira criativa reproduzindo, corrigindo, adaptando e/ou transformando seus saberes. Em síntese, o resguardo do pós-parto abrange um tempo socialmente marcado e se caracteriza pela orquestração de um conjunto de práticas restritivas intencionalmente realizadas pelos Munduruku com o objetivo de manter a saúde, prevenir doenças e evitar a morte.

Notas

71 Paul (1975) citou a centralidade do sangue do parto como fonte de risco, motivando as parteiras Maia a cumprir resguardo após o parto.

72 Ubirajara é curador da etnia Mura, morador de uma vila ribeirinha que faz fronteira com a TIKL. Em Scopel, Dias-Scopel G Wiik (2012) e Scopel (2013), no tópico sobre os curadores Munduruku, é apresentada a relação deles com o curador Ubirajara, no intuito de evidenciar a intensa rede de trocas interétnicas de saberes e de tratamentos, que extrapolava as fronteiras da TIKL.

73 Scopel (2013: 224) apresentou uma história mítica sobre o paradoxo da luta entre o jabuti e o taperebá. Ambos figuram como seres míticos famosos por suas características perenes mesmo em condições adversas: o jabuti pela capacidade de sobreviver por longo período sem se alimentar e o taperebá por sobreviver ao fogo e por longos anos mesmo fora da terra.

74 Descrições sucintas sobre restrições e prescrições do resguardo associado ao pós-parto são encontradas em diferentes etnografias realizadas entre populações indígenas amazônicas (Da Matta, 1976; Melatti, 1978; Ramos, 1990; Vidal, 1977). Apesar de as práticas de resguardo diferirem de um grupo indígena para outro e terem significados igualmente particulares, de maneira geral os dados etnográficos desses trabalhos destacaram que o cumprimento do resguardo não se restringia aos pais do recém-nascido nem a dietas alimentares, estando diretamente relacionado à formação do corpo do bebê, dos pais e das mães, além de ser também um rito de passagem. Entre os Xikrin, por exemplo, além do pai e da mãe da criança, também o irmão da mãe, o pai da mãe, a mãe da mãe, o pai do pai, a mãe do pai e a irmã do pai poderiam cumprir o resguardo (Vidal, 1977). Os Krahó, por sua vez, admitiam que uma criança pode ser gerada por mais de um homem e que todos aqueles que contribuíram com seu sêmen deveriam cumprir o resguardo, que implicaria "não somente em restrições alimentares, como também em abstinência sexual, proibição de fumar e redução do trabalho" (Melatti, 1978: 56).

75 Antônia era cunhada de Ester e ambas foram tradutoras, junto com as pesquisadoras do Summer Institute of Linguistics, na década de 1960, na edição da Bíblia em munduruku. 


\section{Conclusão}

\section{Limites e possibilidades de articulação entre diferentes formas de atenção à saúde}

Na etnografia das práticas de autoatenção à gestação, parto e pós-parto, observei que as mulheres Munduruku articulam os saberes indígenas com práticas biomédicas de atenção à saúde - por exemplo, o acompanhamento pré-natal e exames laboratoriais - e também seguem as prescrições indígenas relativas a dietas alimentares, banhos, "pegar barriga", "puxar a mãe do corpo" reclusão, entre outras que interferem diretamente na produção do corpo e da pessoa Munduruku. Procurei destacar as especificidades dos saberes munduruku em um contexto marcado pelo pluralismo médico e por relações de intermedicalidade e priorizei as atividades de pessoas leigas em relação ao discurso dos especialistas.

Segundo Scopel, Dias-Scopel e Wiik (2012), o contexto de intermedicalidade se constitui como um campo de relações sociais em que os atores envolvidos têm poderes e forças distintos, caracterizados pela assimetria do saber biomédico dado o contexto colonialista em que foi inserido. Nesta etnografia verifiquei que não se pode negar os impactos da atenção biomédica no interior das aldeias indígenas, a exemplo da repercussão de ideologias biomédicas sobre planejamento familiar, cesárea e esterilização feminina. Apesar disso, mantêm-se a atualidade e vivacidade de saberes tidos como tradicionais pelos Munduruku, que são transmitidos ao longo das gerações, e a sua importância para os processos de manutenção da saúde e prevenção e/ou tratamento de enfermidade e infortúnios (Dias-Scopel, Scopel G Langdon, 2017). Não se trata, entretanto, de enfatizar uma dicotomia entre as categorias "moderno" e "tradicional", que figuram como um discurso polarizado no campo da saúde indígena. Esta etnografia evidenciou que há espaços para articulação entre as formas de atenção biomédica e indígenas, apesar da tendência dos profissionais da saúde a ignorar e negar as práticas de autoatenção realizadas pelos Munduruku. De modo geral, sugere-se que a Política Nacional de Atenção à Saúde 
dos Povos Indígenas ainda opera, após 15 anos de implantação, reproduzindo uma imagem distorcida das práticas de saúde dos povos indígenas. Além disso, a atenção primária ofertada no interior das aldeias indígenas continua fortemente orientada pelo paradigma biomédico, que reproduz uma concepção restritiva da saúde e do corpo, com baixa qualidade dos serviços prestados, se avaliados segundo os critérios estabelecidos nas próprias políticas públicas.

Para os Munduruku, a manutenção da saúde e as transformações corporais requerem a ação intencional dos sujeitos, que articulam dimensões sociais e cosmológicas na condução da vida cotidiana. Corpo e saúde, para os Munduruku, portanto, não se restringem à concepção biomédica baseada na dimensão biológica. As noções de saúde, corpo e ambiente são indissociáveis para os Munduruku:

A ocupação do território, o uso de recursos disponíveis e a vida social implicam efeitos sobre os corpos Munduruku, na medida em que a manutenção dos laços sociais e a proteção do ambiente são consideradas por eles como condições necessárias para a reprodução da coletividade. (Scopel, Dias-Scopel G Langdon, 2018: 89)

A gestação e o nascimento de uma criança Munduruku são processos que permitem observar claramente um conjunto de atividades voltado para a construção do corpo e da pessoa, em que o manejo adequado das relações de aproximação e afastamento dos demais seres do cosmo constitui parte central da manutenção e promoção do bem-estar e da saúde, assim como as relações sociais manjadas no interior da família extensa.

Gestação, parto e pós-parto constituem processos sociais que envolvem uma diversidade de atores, entre os quais gestantes, pais, mulheres mais velhas da família extensa, pajés, parteiras e profissionais da saúde. A observação da práxis e do cotidiano permitiu compreender que esses processos têm importância central para os Munduruku, isto é, estão articulados com saberes e práticas relacionados aos usos e manejos do território que mobilizam um conjunto de protocolos de aproximação e afastamentos que se configuram como estratégias de sobrevivência e reprodução biossocial individual e coletiva. Sublinhar a dimensão social e cosmográfica que subjaz às práticas relativas à gestação, parto e pós-parto permite observar a ênfase conferida à dimensão processual, coletiva e criativa da experiência vivida pelos Munduruku. Essas práticas de autoatenção não podem ser compreendidas apenas por um viés obstétrico, ginecológico ou de autocuidado, ao menos nos termos colocados pela forma biomédica de atenção (Menéndez, 2003), demasiadamente individualista e materialista.

A preocupação dos Munduruku com o desejo da mulher gestante e com a dieta no pós-parto, por exemplo, enfatiza a centralidade da alimentação como fator que intervém diretamente na produção do corpo e do caráter moral da criança. Os esforços para satisfazer o desejo, por sua vez, sublinham a importância das relações 
de parentesco, contribuindo para reforçar os laços afetivos e reafirmar os comportamentos e as expectativas adequadas ao contexto da ação e aos atores envolvidos nas relações sociais. De modo semelhante, a preocupação dos Munduruku com o "abalo de criança", que pode acometer os pais, enfatiza a participação desses homens na formação do corpo de seus filhos durante a gestação. Ao contrário do que pressupõe a biomedicina, o pai Munduruku pode contribuir ativamente na produção do corpo do feto durante a gestação, pois a criança puxa gordura, força e vitalidade do pai. Esses exemplos referem-se a algumas das práticas de autoatenção à gestação que salientam a participação ativa do pai, embora a gestação possa incluir também a participação de parentes engajados nas redes de apoio mútuo. Assim, a gestação de uma criança acopla um feixe de relações construídas pela partilha e pela convivência. Do ponto de vista munduruku, o feto já tem agência nessas relações sociais, pois é capaz de interferir nas atividades cotidianas do pai e da mãe. O que significa que as relações de parentesco, entre os Munduruku, demandam um engajamento diário dos sujeitos em práticas de autoatenção à saúde e, por sua vez, a centralidade desses processos na organização do socius, à semelhança de outros povos indígenas (Gow, 1989; Overing, 1999; Viegas, 2003, 2006; Rosengren, 2006; Tassinari, 2007). A abordagem das práticas não requer negar a eficácia do simbólico, mas evita o tratamento excessivamente abstrato da análise e, consequentemente, promove um diálogo mais amplo com um público mais variado de leitores.

Torna-se visível a dimensão estrutural das práticas de autoatenção, isto é, a centralidade que ocupam na manutenção de grupos sociais e na transmissão de saberes e valores sobre o mundo, os quais, é preciso ter clareza, não estão restritos à atuação dos especialistas no trato com a saúde. As práticas de autoatenção à gestação, ao parto e ao pós-parto não constituem saberes herméticos e esotéricos, mas, ao contrário, articulam diferentes saberes apreendidos na experiência individual e coletiva e estão diluídos na sociedade munduruku. Assim, são as mulheres mais velhas das famílias extensas, que podem ou não ser parteiras, que ocupam um papel de destaque na autoatenção a outras mulheres, crianças e homens da família. A dicotomia leigo/especialista é útil para problematizar a tendência das políticas públicas de saúde brasileiras a reproduzir uma concepção da atuação das parteiras restrita à cena do parto domiciliar, sem reconhecer que também pode haver outros atores sociais atuando ao longo da gestação, no parto e no pós-parto que não sejam especialistas.

Entre os Munduruku, as práticas de autoatenção relativas a "pegar barriga" evidenciam a centralidade das mulheres mais velhas das famílias extensas e a importância dos saberes indígenas sobre a formação do corpo da criança no ventre da mãe e a relação desse processo com a cosmografia. A gestação de uma criança envolve muitas incertezas, podendo gerar dúvidas acerca da humanidade do feto. A gravidez de bicho, por exemplo, foi evocada como algo muito grave que 
poderia culminar em aborto e morte. Assim, os saberes transmitidos por gerações de mulheres acerca dos perigos que cercam a gestação versam, em última análise, sobre o distanciamento entre os humanos e os demais seres do cosmo. Essa manutenção das distâncias que regulam a interação social entre humanos e seres que habitam o cosmo munduruku pode ser pensada como prática que orienta a vida cotidiana (Scopel, Dias-Scopel G Langdon, 2018; Dias-Scopel, Scopel G Langdon, 2017). Através da prática de "pegar barriga", as mulheres Munduruku investigaram sobre a humanidade do ser em gestação, por meio de seus saberes sobre a concepção, a fisiologia e a morfologia do feto. A prática de "pegar barriga" sustenta, entre outras questões, uma imagem socialmente compartilhada de como deve ser o corpo de um feto humano. Desse modo, a série de práticas de autoatenção que têm implicações diretas sobre o desenvolvimento de características físicas e morais da criança em gestação evidencia sua importância na construção social do corpo e da pessoa Munduruku, além de ressaltar que corpo e pessoa não são dados de uma natureza biológica, fixa e preexistente. O corpo e a pessoa saudável são uma conquista que resulta de atividades que se iniciam ainda na gestação e são mantidos, ao longo da vida, por meio de um conjunto de práticas que visa ao desenvolvimento de habilidades consoantes aos valores socialmente compartilhados.

A focalização nas práticas de autoatenção à gestação, parto e pós-parto me aproximou, em particular, das atividades manejadas em um momento específico do fluxo de vida de um homem e de uma mulher Munduruku. Essas práticas de autoatenção abrangem um esforço da parte de ambos em garantir o bem-estar da criança e de si mesmos, como mãe e pai. Sugeri aqui que o cumprimento das práticas de resguardo do pós-parto poderia ser pensado como modo de evitar os perigos advindos do contato com os seres que habitam o cosmo, dado que o sangue teria uma qualidade volátil capaz de atrair tais seres, com os quais as relações sociais frequentemente resultam em doenças e mortes. Ainda mais, sugeri que o cumprimento do resguardo era de interesse direto de toda a comunidade, posto que tais perigos de doença e morte se estenderiam a qualquer pessoa que passasse pelo rastro do sangue deixado pela mulher menstruada ou pela mulher parida. Logo, as práticas de autoatenção, como, por exemplo, a reclusão das mulheres durante o resguardo, podem ser compreendidas como processo de construção social do corpo, da pessoa e da coletividade munduruku, assim como outras etnografias das populações amazônicas sugerem (Belaunde, 2005; Conklin, 2001; Da Matta, 1976; Motta-Maués, 1994; Seeger, Da Matta G Viveiros de Castro, 1979 Overing, 1999; Viegas, 2003; Rosengren, 2006; Tassinari, 2007).

O homem Munduruku contribui para produzir a pessoa e o corpo da mulher Munduruku durante a gestação, o parto e o pós-parto, pois ele tem um papel importante no resguardo do pós-parto da mulher. Ao cumprir o resguardo, ao permanecer vários dias dentro de casa e ao evitar banhar-se na beira, as mulheres 
estavam se engajando nas expectativas sociais relacionadas ao que é ser mãe entre os Munduruku. Os homens as auxiliavam nos cuidados da casa, dos filhos, com a alimentação, cumprindo, por sua vez, um conjunto de atividades do cotidiano feminino como atributo da paternidade, ao menos durante o período do resguardo do parto. Ao mesmo tempo, deveriam evitar uma série de atividades do cotidiano masculino, especificamente aquelas que pudessem fazer com que o recém-nascido sangrasse pelo umbigo. Enfim, a cooperação entre homens e mulheres como um valor socialmente construído se atualizava nas práticas de autoatenção, posto que homens e mulheres Munduruku executavam atividades distintas, mas complementares, cada qual contribuindo com um conjunto de habilidades que colaboravam para compor as relações de gênero.

As práticas realizadas durante a gestação, o parto e o pós-parto pelos Munduruku, em um sentido amplo, constituem empreendimentos de ordem social voltados para a formação e a manutenção de parentes, da pessoa, do corpo e do gênero. Cumprir ou não determinadas ações pode afetar a saúde dos pais e das crianças, além de exercer impacto sobre o desenvolvimento de uma pessoa, cujas habilidades e capacidades são produzidas desde a gestação. Nessa perspectiva, a intencionalidade é fator que transpassa as práticas de autoatenção à gestação, ao parto e ao pós-parto. Ao "pegar barriga", ao procurar saciar o desejo, ao resistir ao "abalo de criança" e ao cumprir a prática do resguardo no pós-parto, os Munduruku estão participando de um processo de caráter intersubjetivo, que envolve a performance de diversos atores. E, atualmente, esse processo inclui atores participantes da forma de atenção biomédica.

O crescente processo de medicalização da gestação, do parto e do pós-parto resulta de fatores macrossociais, entre os quais se destaca a expansão do modelo biomédico como advento da modernização e da colonização, o qual inclui as populações indígenas na atualidade. Esses processos macrossociais encontram ressonância em expectativas locais, como no caso das mulheres Munduruku que realizaram cesárea com a intenção de fazer a laqueadura, incentivadas por políticas de planejamento familiar apreendidas na relação interétnica e por meio da atuação cotidiana dos profissionais da saúde. Esse cenário de crescente contato dos indígenas com a forma de atenção biomédica tem gerado novas situações marcadas por assimetrias de poder e por hierarquização de saberes. Então, torna-se lícito questionar: que hábitos, discursos e experiências vêm se configurando no uso da forma de atenção biomédica pelas populações indígenas? Principalmente porque a biomedicina é tida pelos Munduruku como um recurso imprescindível na atualidade. Assim, por um lado a medicalização da gestação, do parto e do pós-parto se sustenta em políticas de inclusão voltadas para a diminuição da mortalidade materno-infantil como esforço para equacionar as desigualdades sociais. Por outro, repousa nas ações e em decisões tomadas pelos próprios Munduruku, de maneira relativamente 
autônoma em relação aos especialistas biomédicos, em processos de saúde-doença-atenção (Menéndez, 2003, 2005, 2009).

Conforme sugeriu Lock (2004), a etnografia tem o potencial de contextualizar a complexidade da relação entre a aceitação e a resistência aos usos pragmáticos dos serviços e da tecnologia biomédica. Assim, em um contexto de pluralidade médica, emergem juízos de valor sobre as diversas formas de atenção à saúde e às enfermidades (Menéndez, 2005; Sargent G Bascope, 1996). Embora a Política Nacional de Atenção à Saúde dos Povos Indígenas (Brasil, 2002a) incentive a promoção da atenção diferenciada, sensível às especificidades sociais, epidemiológicas e operacionais dos povos indígenas, a forma de atenção biomédica tende a negar, ignorar ou desconsiderar os demais saberes e práticas manejados pela população (Menéndez, 2009). Segundo Menéndez, os serviços de saúde deveriam buscar uma articulação entre os saberes biomédicos e os saberes de autoatenção das populações atendidas, visto que a autoatenção é um processo estrutural, contínuo e acessível, como forma de melhorar a própria eficácia e qualidade do serviço prestado.

A etnografia das práticas de autoatenção à gestação, ao parto e ao pós-parto me permitiu compreender o campo de relações cosmopolíticas em que os atores sociais se engajaram ao vivenciarem esses processos. Evidentemente, esse engajamento está relacionada à cosmologia dos Munduruku, a qual, por seu caráter sui generis, está inserida em um contexto histórico, geográfico e social em que não se pode ignorar a pluralidade médica e de relações interétnicas, marcadas por subjetividades e intencionalidades diversas, algumas vezes convergentes, outras não. Espero, assim, contribuir igualmente para uma reflexão crítica sobre a atenção diferenciada, considerando-a uma noção e um campo social ainda em construção. Nesse sentido, as práticas de autoatenção devem ser consideradas pelos serviços de saúde, pois ocupam um papel central e constante nas estratégias de enfrentamento diário dos infortúnios e das enfermidades e nas atividades de prevenção. Tais práticas não são redutíveis à ação dos especialistas em momentos críticos, elas constituem atividades cotidianas manejadas pelos sujeitos de modo intencional na condução da vida. Cumpre problematizar, também, o impacto das ações setorializadas no campo da saúde indígena, nas quais se ignoram "os conhecimentos tradicionais sobre saúde e ambiente, de modo que a política de desenvolvimento econômico atua contra as necessidades plenas de bem-estar" (Scopel, Dias-Scopel G Langdon, 2018).

Por último, gostaria de registrar que o trabalho de campo etnográfico consistiu, para mim, em uma atividade engajada em práticas de autoatenção munduruku. Meu próprio corpo serviu como veículo de aprendizado sobre os modos de produção de corpos, pessoas e de manutenção das relações sociais afetivas praticados entre os Munduruku. Parafraseando Bloch (1992: 144), em certa medida esta etnografia é produto do modo como aprendi vivendo na sociedade munduruku, ao 
observar os casais durante a gestação e o pós-parto, ao compartilhar minha experiência de gestação no interior de uma família extensa e ao fazer o pré-natal junto com outras mulheres Munduruku, participando no plantio da roça, na fabricação da farinha, na troca de alimentos, além de ouvir o que eles tinham a dizer sobre tudo isso. 


\section{Referências}

AMOROSO, M. Corsários no caminho fluvial, os Mura do rio Madeira. In: CUNHA, M. C.

(Org.). História dos Índios no Brasil. São Paulo: Companhia das Letras, 1992.

ARNAUD, E. Os índios Mundurukú e o Serviço de Proteção aos Índios. Boletim do Museu Paraense Emílio Goeldi - Nova Série, 54: 1-60, 1974.

ARNAUD, E. O índio e a assistência oficial: a história de vida do índio Sabino Apompés Tapajós Munduruku. Revista de Antropologia, 30: 225, 1989.

BELAUNDE, L. E. El Recuerdo de Luna: género, sangre y memoria entre los pueblos amazónicos. Lima: Fondo Editorial de la Facultad de Ciencias Sociales (UNMSM), 2005.

BELAUNDE, L. E. A força dos pensamentos, o fedor do sangue: hematologia e gênero na Amazônia. Revista de Antropologia, 49(1): 205-243, 2006.

BLASER, M. Is another cosmopolitics possible? Cultural Anthropology, 31(4): 545-570, 2016.

BLOCH, M. What goes without saying: the conceptualization of Zafimaniry society. In: KUPER, A. (Ed.). Conceptualizing Society. London, New York: Routlegde, 1992.

BOCCARA, G. La interculturalidad como campo social. Cuadernos Interculturales, 10(18): $11-30,2012$.

BRASIL. Senado Federal. Constituição da República Federativa do Brasil. Diário Oficial da União, Brasília, 1988.

BRASIL. Ministério da Saúde. Portaria n. 569, de $1^{\circ}$ de junho de 2000. Programa de Humanização do Pré-Natal e Nascimento. Brasília: Ministério da Saúde, 2000.

BRASIL. Política Nacional de Atenção à Saúde dos Povos Indígenas. 2. ed. Brasília: Funasa, 2002a.

BRASIL. Ministério da Saúde. Relatório de Gestão Secretaria de Assistência à Saúde 19982001. Brasília: Ministério da Saúde, Secretaria de Assistência à Saúde, 2002b.

BRASIL. Política Nacional de Atenção Integral à Saúde da Mulher: Plano de Ação 2004-2007. Brasília: Ministério da Saúde, 2004a.

BRASIL. Ministério da Saúde, Secretaria de Atenção à Saúde, Departamento de Ações Programáticas Estratégicas. Política Nacional de Atenção Integral à Saúde da Mulher: princípios e diretrizes. Brasília: Ministério da Saúde, 2004b.

BRASIL. Ministério da Saúde. Pacto pela Redução da Mortalidade Materna e Neonatal. Brasília: Ministério da Saúde, 2004c.

BRASIL. Ministério da Saúde. Secretaria de Atenção à Saúde. Departamento de Ações Programáticas Estratégicas. Área Técnica de Saúde da Mulher. Pré-Natal e Puerpério: atenção qualificada e humanizada. Manual técnico. 3. ed. Brasília: Ministério da Saúde, 2005. (Série A. Normas e Manuais Técnicos. Série Direitos Sexuais e Direitos Reprodutivos, Caderno n. 
5). Disponível em: < http://bvsms.saude.gov.br/bvs/publicacoes/manual_pre_natal_puerperio_3ed.pdf>. Acesso em: 4 out. 2018.

BRASIL. Ministério da Saúde. Saúde da Criança - Nutrição Infantil: aleitamento materno e alimentação complementar. Brasília: Ministério da Saúde, 2009.

BRASIL. Política Nacional de Alimentação de Nutrição. Atribuições das equipes de saúde no Programa Bolsa Família na Saúde. Disponível em: < http://nutricao.saude.gov.br/atribuicoesEquipesPbf.php>. Acesso em: 9 ago. 2012.

CARDOSO, R. B. Trabalho apresentado no curso de Licenciatura Indígena. Borba, 2011 (Mimeo.)

CARSTEN, J. Antisubstantivism, and anti-antisubstantivism. In: FRANKLIN, S. G MCKINNON, S. (Eds.). Relative Values: reconfiguring kinship studies. Durham: Duke University Press, 2001.

CARSTEN, J. The substance of kinship and the heat of the hearth: feeding, personhood, and relatedness among Malays in Pulau Langkawi. In: PARKIN, R. G STONE, L. (Eds.). Kinship and Family: an anthropological reader. Malden: Blackwell, 2004.

CASAL, M. A. Corografia Brasílica ou Relação Histórico-Geográfica do Reino do Brasil, 1817. 2 vol. (Fac-símile da primeira edição)

COIMBRA JR., C. E. A. G GARNELO, L. Questões de saúde reprodutiva da mulher indígena no Brasil. In: MONTEIRO, S. G SANSONE, L. (Eds.). Etnicidade na América Latina: um debate sobre raça, saúde e direitos reprodutivos. Rio de janeiro: Editora Fiocruz, 2004.

COIMBRA JR., C. E. A. et al. Inquérito Nacional de Saúde e Nutrição dos Povos Indígenas. Relatório Final (Análise dos dados). Rio de Janeiro: Funasa, Abrasco, 2009. Disponível em: < http://www.abrasco.org.br/grupos/arquivos/2013-01-23\%2013:44:23.pdf>. Acesso em: 19 out. 2013 .

COLLEVATTI, J. Do trabalho missionário para se salvar uma nação: um estudo dos sucessos missionários. Religião G Sociedade, 29(1): 223-250, 2009.

COMAROFF, J. Introduction. In: COMAROFF, J. Body of Power, Spirit of Resistance: the culture and history of a South African people. Chicago: University of Chicago Press, 2013.

CONKLIN, B. Reflections on Amazonian anthropologies of the body. Medical Anthropology Quarterly, 10(3): 373-375, 1996.

CONKLIN, B. Women's blood, warriors' blood, and the conquest of vitality in Amazonia. In: GREGOR, T. G TUZIN, D. (Eds.). Gender in Amazonia and Melanesia: an exploration of the comparative method. Berkley: The University of California Press, 2001.

CONKLIN, B. Shamans versus pirates in the Amazonian tresure chest. American Anthropology, 104(4): 1.050-1.061, 2002.

CONKLIN, B. G MORGAN, L. M. Babies, bodies, and the production of personhood in North America and a native Amazonian society. Ethos, 24(4): 657-694, 1996. 
DA MATTA, R. Panema: uma tentativa de análise estrutural. In: DA MATTA, R. Ensaios de Antropologia Estrutural. Petrópolis: Vozes, 1973.

DA MATTA, R. Um Mundo Dividido: a estrutura social dos índios Apinayé. Petrópolis: Vozes, 1976.

DIAS-SCOPEL, R. P. O Agente Indígena de Saúde Xokleng: por um mediador entre a comunidade indígena e o serviço de atenção diferenciada à saúde - uma abordagem da antropologia da saúde, 2005. Dissertação de Mestrado, Florianópolis: Universidade Federal de Santa Catarina.

DIAS-SCOPEL, R. P. G SCOPEL, D. ¿Quiénes son las parteras Munduruku? Pluralismo médico y autoatención en el parto domiciliario entre indígenas en Amazonas, Brasil. Desacatos, 16(58): 16-33, 2018.

DIAS-SCOPEL, R. P.; LANGDON, E. J. G SCOPEL, D. Expectativas emergentes: a inserção do agente indígena de saúde Xokleng na equipe multidisciplinar de atenção à saúde indígena. Tellus, 13: 51-73, 2007.

DIAS-SCOPEL, R. P.; SCOPEL, D. G LANGDON, E. J. Gestação, parto e pós-parto entre os Munduruku do Amazonas: confrontos e articulações entre o modelo médico hegemônico e práticas indígenas de autoatenção. Ilha, Revista de Antropologia, 19: 183-216, 2017.

DIEHL, E. E.; DIAS-SCOPEL, R. P. G LANGDON, E. J. Contribuição dos agentes indígenas de saúde na atenção diferenciada à saúde dos povos indígenas brasileiros. Cadernos de Saúde Pública, 28(5): 819-831, 2012.

EVANS-PRITCHARD, E. Bruxaria, Oráculos e Magia entre os Azande. Rio de Janeiro: Jorge Zahar, 2005.

FAVRET SAADA, J. Ser afetado. Cadernos de Campo: Revista dos Alunos de Pós-Graduação em Antropologia Social da USP, 14(13): 155-161, 2005.

FERREIRA, L. O. Medicinas Indígenas e as Políticas da Tradição: entre discursos oficiais e vozes indígenas. Rio de Janeiro: Editora Fiocruz, 2013. (Saúde dos Povos Indígenas)

FIEDLER, D. C. Authoritative knowledge and birth territories in contemporary Japan. Medical Anthropology Quarterly, 10(2): 195-212, 1996.

FRANKENBERG, R. Medical anthropology and development: a theoretical perspective. Social Science G Medicine. Part B. Medical Anthropology, 14(4): 197-207, 1980.

FUNDAÇÃO NACIONAL DO ÍNDIO (FUNAI). Ministério da Justiça. Mapa de Demarcação Terra Indígena Kwatá-Laranjal. 2002.

GARNELO, L. Poder, Hierarquia e Reciprocidade: saúde e harmonia entre os Baniwa do Alto Rio Negro. Rio de Janeiro: Editora Fiocruz, 2003. (Saúde dos Povos Indígenas)

GARNELO, L. Política de Saúde Indígena no Brasil: notas sobre as tendências atuais do processo de implantação do subsistema de atenção à saúde. In: GARNELO, L. G PONTES, A. L. (Orgs.). Saúde Indígena: uma introdução ao tema. Brasília: MEC/Secadi, 2012. 
GEERTZ, C. A Interpretação das Culturas. Rio de Janeiro: LTC, 1989.

GEERTZ, C. Do ponto de vista dos nativos: a natureza do entendimento antropológico. In: GEERTZ, C. O Saber Local: novos ensaios e antropologia interpretativa. Petrópolis: Vozes, 1997.

GIBERTI, A. C. Nascendo, Encantando e Cuidando: uma etnografia do processo de nascimento nos Pankarau de Pernambuco, 2013. Tese de Doutorado, São Paulo: Universidade de São Paulo.

GOW, P. The perverse child: desire in a native Amazonian subsistence economy. Man, 24(4): 567-582, 1989.

GOW, P. River people: shamanism and history in Western Amazonia. In: THOMAS, N. G HUMPHREY, C. (Eds.). Shamanism, History, and the State. Ann Arbor: University of Michigan Press, 1996.

GREENE, S. The shaman's needle: development, shamanic agency, and intermedicality in Aguaruna Lands, Peru. American Ethnologist, 25(4): 634-658, 1998.

HECKENBERGER, M. J. The enigma of great cities: body and State in Amazonia. Tipití, 1(1): 27-58, 2003.

HERTZ, R. A preeminência da mão direita: um estudo sobre a polaridade religiosa [1909]. Religião e Sociedade, 6, 1980.

IORIS, E. M. A Forest of Disputes: struggles over spaces, resources and social identities in Amazônia, 2005. Dissertation (PhD), Gainesville: University of Florida.

IORIS, E. M. Reelaboração das identidades étnicas no Baixo Rio Tapajós. In: SABERES E PRÁTICAS ANTROPOLÓGICAS: DESAFIOS PARA O SÉCULO XXI. REUNIÃO BRASILEIRA DE ANTROPOLOGIA, XXV, 2006. Anais... Brasília: Associação Brasileira de Antropologia (ABA), 2006.

IORIS, E. M. Identidades negadas, identidades construídas: processos identitários e conflitos territoriais na Amazônia. Ilha, Revista de Antropologia, 11(1-2): 219-264, 2011.

KEESING, R. M. Theories of culture revisited. In: BOROFSKY, R. (Ed.). Assessing Cultural Anthropology. New York: McGraw-Hill, 1994.

LANGDON, E. J. Ideology of the Northwest Amazon: cosmology, ritual, and daily life. Reviews in Anthropology, 9(4): 349-359, 1982

LANGDON, E. J. When tapir is an anaconda: women and power among the Siona. Latin American Indian Literatures Journal, 7(1): 7-19, 1991.

LANGDON, E. J. A doença como experiência: construção da doença e seu desafio para a prática médica. Antropologia em Primeira Mão, n. 12. Florianópolis: PPGAS-UFSC, 1995. Palestra na Conferência 30 Anos Xingu. Escola Paulista de Medicina, São Paulo, 23 ago. 1995. Disponível em: <http://www.antropologia.com.br/tribo/nessi/textos/a_doenca_ como_experiencia.htm>. Acesso em: 10 set. 2018. 
LANGDON, E. J. Problematizando os projetos de medicina tradicional indígena. In: BRASIL. Ministério da Saúde. Fundação Nacional de Saúde. Projeto Vigisus II - Saúde Indígena. Medicina Tradicional Indígena em Contextos. Anais da I Reunião de Monitoramento. Brasília: Fundação Nacional de Saúde, 2007.

LANGDON, E. J. Medicina tradicional: reflexões antropológicas sobre atenção diferenciada. In: HAVERROTH, M. (Ed.). Etnobiologia e Saúde dos Povos Indígenas: estudos avançados. Recife: Nupeea, 2013.

LANGDON, E. J. et al. A participação dos agentes indígenas de saúde nos serviços de atenção à saúde: a experiência em Santa Catarina. Cadernos de Saúde Pública, 22(12): 2.637-2.646, 2006.

LASMAR, C. Mulheres indígenas: representações. Estudos Feministas, 7(1-2): 143, 1999.

LEENHARDT, M. Do Kamo: la personne et le mythe dans le monde mélanésien. Paris: Gallimard, 1971.

LITTLE, P. E. Amazonia: territorial struggles on perennial frontiers. Baltimore, London: Johns Hopkins University Press, 2001.

LOCK, M. Medicalization and the naturalization of social control. In: EMBER, C. R. (Ed.). Encyclopedia of Medical Anthropology. New York: Kluwer Academic, Plenum Publishers, 2004.

LOCK, M. G SCHEPER-HUGHES, N. A Critical-interpretative approach in medical anthropology: rituals and routines of discipline and dissent. In: SARGENT, C. F. G JOHNSON, T. M. (Eds.). Medical Anthropology: contemporary theory and method. Revised ed. New York: Praeger Paperback, 1996.

MARCUS, G. E. G FISCHER, M. M. J. Anthropology as Cultural Critique: an experimental moment in the human sciences. Chicago: University of Chicago Press, 1999.

MAUÉS, R. H. G MOTTA-MAU S, M. A. O modelo da "reima": representações alimentares em uma comunidade amazônica. Anuário Antropológico, 77: 120-147, 1978.

MAUSS, M. As técnicas do corpo. In: MAUSS, M. Sociologia e Antropologia [1934]. São Paulo: Cosac G Naify, 2003a.

MAUSS, M. Uma categoria do espírito humano: a noção de pessoa, a de "eu". In: MAUSS, M. Sociologia e Antropologia [1938]. São Paulo: Cosac G Naify, 2003b.

MCCALLUM, C. Aquisição de gênero e habilidades produtivas: o caso Kaxinawá. Estudos Feministas, 7(2): 157-175, 1999.

MCCALLUM, C. Gender and Sociality in Amazonia: how real people are made. Oxford: Berg, 2001.

MELATTI, J. C. Ritos de uma Tribo Timbira. São Paulo: Ática, 1978.

MELATTI, J. .C. Amazônia Centro-Meridional. Disponível em: < http://e-groups.unb.br/ics/ dan/juliomelatti/ias-az4/txazctme.htm>. Acesso em: 28 maio 2010. 
MENÉNDEZ, H. Uma contribuição para a etno-história da área Tapajós-Madeira. Revista do Museu Paulista, 28: 289-388, 1981.

MENÉNDEZ, E. L. A área Madeira-Tapajós. In: CUNHA, M. C. (Org.). História dos Índios no Brasil. São Paulo: Companhia das Letras, 1992.

MENÉNDEZ, E. L. Modelos de atención de los padecimientos: de exclusiones teóricas y articulaciones prácticas. Ciência G Saúde Coletiva, 8: 185-207, 2003.

MENÉNDEZ, E. L. Intencionalidad, experiencia y función: la articulación de los saberes médicos. Revista de Antropologia Social, 14: 33-69, 2005.

MENÉNDEZ, E. L. Sujeitos, Saberes e Estruturas: uma introdução ao enfoque relacional no estudo da saúde coletiva. São Paulo: Hucitec, 2009.

MENÉNDEZ, E. L. Modelos, experiencias y otras desventuras. In: HARO, J. A. (Ed.). Epidemiología Sociocultural: un diálogo en torno a su sentido, métodos y a alcances. Buenos Aires, Hermosillo: Lugar Editorial, Colegio de Sonora, 2011. (Salud Colectiva)

MENGET, P. Notas sobre as cabeças Mundurukú. In: VIVEIROS DE CASTRO, E. B. G CUNHA, M. C. (Eds.). Amazônia: etnologia e história indígena. São Paulo: Núcleo de História Indígena e do Indigenismo, 1993.

MENGET, P. De l'usage des trophées en Amérique du Sud: esquisse d'une comparaison entre les pratiques Nivacle (Paraguay) et Mundurucu (Brésil). Systèmes de Pensée en Afrique Noire, 14: 127-144, 1996.

MÉTRAUX, A. A Religião dos Tupinambás e suas Relações com a das Demais Tribos Tupi-Guaranis. São Paulo: Cia Editora Nacional, Edusp, 1979.

MOTTA-MAUÉS, M. A. "Lugar de mulher": representações sobre os sexos e práticas médicas na Amazônia (Itapuá, Pará). In: ALVES, P. C. G MINAYO, M. C. S. (Orgs.). Saúde e Doença: um olhar antropológico. Rio de Janeiro: Editora Fiocruz, 1994.

MURPHY, R. F. Mundurucu Religion. Berkeley: University of California Press, 1958.

MURPHY, R. F. Headhunter's in Heritage: social and economic change among the Mundurucu indians. Berkeley: University of California Press, 1960.

MURPHY, Y. G MURPHY, R. F. Women of the Forest [1974]. 30. ed. New York: Columbia University Press, 2004.

NEWMAN, L. The anthropology of birth. Sociological Symposium - Anais, 1972.

OLIVEIRA FILHO, J. P. Uma etnologia dos "índios misturados"? Situação colonial, territorialização e fluxos culturais. Mana, 4(1): 47-77, 1998.

ORTNER, S. B. Introduction; subjectivity and cultural critique; power and projects: reflections on agency. In: ORTNER, S. B. Anthropology and Social Theory: culture, power an acting subject. Durham, London: Duke University Press, 2006.

OVERING, J. Elogio do cotidiano: a confiança e a arte da vida social em uma comunidade amazônica. Mana, 5(1): 81-107, 1999. 
PAUL, L. Recrutment to a ritual role. Ethos, 3(3): 449-468, 1975.

PÉREZ-GIL, L. Chamanismo e modernidade: fundamentos etnográficos de um processo histórico. In: CALAVIA SÁES, Ó.; LENAERTS, M. G SPADAFORA, A. M. (Eds.). Paraíso Abiertos, Jardines Cerrados. Quito: Abya-Yala, 2004.

PÉREZ-GIL, L. Metamorfoses Yaminawa: xamanismo e socialidade na Amazônia peruana, 2006. Tese de Doutorado, Florianópolis: Universidade Federal de Santa Catarina.

PÉREZ-GIL, L. Políticas de saúde, pluralidade terapêutica e identidade na Amazônia. Saúde G Sociedade, 16(2): 48-60, 2007a.

PÉREZ-GIL, L. Possibilidades de articulação entre os sistemas de parto tradicionais indígenas e o sistema oficial de saúde no Alto Juruá. In: FERREIRA, L. O. G OSÓRIO, P. (Orgs.). Medicina Tradicional Indígena em Contextos: anais da Primeira Reunião de Monitoramento. Brasília: Funasa, 2007b.

PÉREZ-GIL, L. G WAKANÃ, G. S. Caracterização dos sistemas de parto tradicionais entre os povos indígenas de Alagoas e Pernambuco: resultados da primeira etapa. In: FERREIRA, L. O. G OSÓRIO, P. (Orgs.). Medicina Tradicional Indígena em Contextos: anais da Primeira Reunião de Monitoramento. Brasília: Funasa, 2007.

PLATT, T. El feto agresivo: parto, formación de la persona y mito-historia en los Andes. Estudios Atacameños, 22: 127-155, 2002.

RAMOS, A. R. Mundurucu: social change or false problem? American Ethnologist, 5(4): 675-689, 1978.

RAMOS, A. R. Memórias Sanumá: espaço e tempo em uma sociedade Yanomami. São Paulo, Brasília: Marco Zero, Editora UnB, 1990.

RAMOS, A. R. O índio hiper-real. Revista Brasileira de Ciências Sociais, 28(10): 5-14, 1995.

RAMOS, A. R. F. Entre a Cruz e a Riscadeira: catequese e empresa extrativista entre os Mundurkú (1910-1950), 2000. Dissertação de Mestrado, Goiânia: Faculdade de Ciências Humanas e Filosofia, Universidade Federal de Goiás.

RIBEIRO, D. Os Índios e a Civilização: a integração das populações indígenas no Brasil moderno [1970]. São Paulo: Companhia das Letras, 2002.

RIVAL, L. The growth of family trees: understanding Huaorani perceptions of the forest. Man, 28: 635-652, 1993.

RIVAL, L. Modernity and the politics of identity in an Amazonian society. Bulletin of Latin American Research, 16(2): 137-151, 1997.

ROSENGREN, D. Corporeidade Matsigenka: uma realidade não biológica sobre noções de consciência e a constituição da identidade. Revista de Antropologia, 49(1): 133-163, 2006.

SAHLINS, M. O "pessimismo sentimental" e a experiência etnográfica: por que a cultura não é um "objeto" em via de extinção (Parte I). Mana, 3(1): 41-73, 1997a. 
SAHLINS, M. O "pessimismo sentimental" e a experiência etnográfica: por que a cultura não é um "objeto" em via de extinção (Parte II). Mana, 3(2): 103-150, 1997b.

SAHLINS, M. Cultura na Prática. 2. ed. Rio de Janeiro: Editora UFRJ, 2007.

SALEM, T. O casal igualitário: princípios e impasses. Revista Brasileira de Ciências Sociais, 3(9): 24-37, 1989.

SANTOS, A. F. M. Conflitos Fundiários, Territorialização e Disputas Classificatórias: Autazes $(A M)$, primeiras décadas do século $X X, 2009$. Tese de Doutorado, Rio de Janeiro: Museu Nacional, Universidade Federal do Rio de Janeiro.

SANTOS, F. J. (Ed.). Dossiê Munduruku: uma contribuição para a história indígena da Amazônia Colonial. Boletim Informativo do Museu Amazônico, 5: 1-103, 1995.

SANTOS, F. J. Além da Conquista: guerras e rebeliões indígenas na Amazônia pombalina. Manaus: Editora da Universidade do Amazonas, 2002.

SARGENT, C. G BASCOPE, G. Ways of knowing about birth in three cultures. Medical Anthropology Quarterly, 10(2): 213-236, 1996.

SCHNEIDER, D. American Kinship a Cultural Account. Princeton: University of Chicago Press, 1968.

SCHNEIDER, D. A Critique of the Study of Kinship. Ann Arbor: University of Michigan Press, 1984

SCHNEIDER, D. What is kinship all about? In: PARKIN, R. G STONE, L. (Eds.). Kinship and Family: an anthropological reader [1972]. Malden: Blackwell, 2004.

SCOPEL, D. Saúde e Doença entre os Índios Mura de Autazes (Amazonas): processos socioculturais e a práxis da autoatenção, 2007. Dissertação de Mestrado, Florianópolis: Universidade Federal de Santa Catarina.

SCOPEL, D. Uma Etnografia sobre a Pluralidade de Modelos de Atenção à Saúde entre os Índios Munduruku na Terra Indígena Kwatá Laranjal, Borba, Amazonas: práticas de autoatenção, xamanismo e biomedicina, 2013. Tese de Doutorado, Florianópolis: Universidade Federal de Santa Catarina.

SCOPEL, D. G DIAS-SCOPEL, R. P. Relatório final: sistematização parcial dos dados etnográficos de pesquisa na Terra Indígena Kwatá Laranjal, Amazonas. s. l.: s. n., 2010. (Mimeo.)

SCOPEL, D.; DIAS-SCOPEL, R. P. G DIEHL, E. E. A "produção" de dados, o controle e o planejamento: um olhar antropológico sobre o trabalho de Equipes Multiprofissionais de Saúde Indígena na Terra Indígena Kwatá-Laranjal, Amazonas. In: CONGRESSO IBERO-AMERICANO DE PESQUISA QUALITATIVA EM SAÚDE, IV, 2010, Fortaleza. Anais... Fortaleza: Abrasco, 2010.

SCOPEL, D.; DIAS-SCOPEL, R. P. G LANGDON, E. J. A cosmografia munduruku em movimento: saúde, território e estratégias de sobrevivência na Amazônia brasileira. Boletim do Museu Paraense Emílio Goeldi. Ciências Humanas, 13: 89-108, 2018. 
SCOPEL, D.; DIAS-SCOPEL, R. P. G WIIK, F. B. Cosmologia e intermedicalidade: o campo religioso e a autoatenção às enfermidades entre os índios Munduruku do Amazonas, Brasil. Tempus Actas de Saúde Coletiva, 6(1): 173-190, 2012.

SEEGER, A. Os Índios e Nós: estudos sobre sociedades tribais brasileiras. Rio de Janeiro: Campus, 1980.

SEEGER, A.; DA MATTA, R. G VIVEIROS DE CASTRO, E. B. A construção da pessoa nas sociedades indígenas brasileiras. Boletim do Museu Nacional - Antropologia, 32: 2-19, 1979.

SESIA, P. M. "Women come here on their own when they need to": prenatal care, authoritative knowledge, and maternal health in Oaxaca. Medical Anthropology Quarterly, 10(2): 121-140, 1996.

SILVA, C. D. Cotidiano, Saúde e Política: uma etnografia dos profissionais da saúde indígena, 2011. Tese de Doutorado, Brasília: Universidade de Brasília.

SPIX, J. B. Von G MARTIUS, K. F. P. Von. Viagem pelo Brasil: 1817-1820. v. 3. 3. ed. São Paulo: Melhoramentos, 1976.

STEFANELLO, J.; NAKANO, M. A. S. G GOMES, F. A. Crenças e tabus relacionados ao cuidado no pós-parto: o significado para um grupo de mulheres. Acta Paulista de Enfermagem, 21(2): 275-281, 2008.

STRATHERN, M. Introdução. In: STRATHERN. O Gênero da Dádiva: problemas com as mulheres e problemas com a sociedade na Melanésia. Campinas: Unicamp, 2006.

TASSINARI, A. Concepções indígenas de infância no Brasil. Tellus, (13): 11-25, 2007.

TEIXEIRA, P. (Org). Sateré-Mawé: retrato de um povo indígena. Manaus: Fundação Joaquim Nabuco, 2005.

TEMPESTA, G. A. A Produção Continuada dos Corpos: práticas de resguardo entre os Wapichana e os Macuxi em Roraima, 2004. Dissertação de Mestrado, Campinas: Instituto de Filosofia e Ciências Humanas, Universidade Estadual de Campinas.

TOCANTINS, A. M. G. Estudos sobre a tribo Munduruku. Revista Trimestral do Instituto Histórico, Geográfico e Etnográfico do Brasil, 73-161, 1877.

TORNQUIST, C. S. Parto e Poder: o movimento pela humanização do parto no Brasil, 2004. Tese de Doutorado, Florianópolis: Centro de Filosofia e Ciências Humanas, Universidade Federal de Santa Catarina.

TURNER, T. The beautiful and the commom: inequalities of values and revolving hierarchy among the Kayapó. Tipití, 1(1): 11-26, 2003.

TURNER, V. O Processo Ritual: estrutura e antiestrutura. Petrópolis: Vozes, 1974.

TURNER, V. Social dramas and stories about them. Critical Inquiry, 7(1): 141-168, 1980.

VAN GENNEP, A. Os Ritos de Passagem. Petrópolis: Vozes, 1978. 
VIDAL, L. B. Morte e Vida de uma Sociedade Indígena Brasileira. São Paulo: Edusp, 1977.

VIEGAS, S. M. Eating with your favourite mother: time and sociality in a Brazilian Amerindian Community. The Journal of the Royal Anthropological Institute, 9(1): 21-37, 2003.

VIEGAS, S. M. Nojo, prazer e persistência: beber fermentado entre os Tupinambá de Olivença (Bahia). Revista de História, 154: 151-188, 2006.

WAGNER, R. The Invention of Culture. Chicago: The University of Chicago, 1981.

WAWZYNIAK, J. V. Assombro de Olhada de Bicho: uma etnografia das concepções e ações em saúde entre os ribeirinhos do Baixo Rio Tapajós. Pará, Brasil, 2008. Tese de Doutorado, Campinas: Instituto de Filosofia e Ciências Humanas, Universidade Estadual de Campinas.

WAWZYNIAK, J. V. "Engerar": uma categoria cosmológica sobre pessoa, saúde e corpo. Ilha, Revista de Antropologia, 5(2): 33-55, 2010.

WEBER, M. Economia e Sociedade [1922]. Brasília: Editora UnB, 2009.

WIIK, F. B. Christianity Converted: an ethnographic analysis of the Xokleng Laklanõ and the transformations resulting from their encounter with Pentecostalism, 2004. Ph. D. Dissertation, Chicago: Department of Social Anthropology, University of Chicago.

WOLF, E. Rubber gathers: Mundurucú. In: WOLF, E. Europe and the People without History. Berkeley: University of California Press, 1997.

YOUNG, A. Some implications of medical beliefs and practices for social anthropology. American Anthropologist, 78(1): 5-24, 1976. 


\section{Outros títulos da coleção Saúde dos Povos Indígenas}

Saúde Indígena em Perspectiva: explorando suas matrizes históricas e ideológicas Carla Costa Teixeira e Luiza Garnelo (orgs.), 2014

Processos de Alcoolização Indígena no Brasil: perspectivas plurais Maximiliano Loiola Ponte de Souza (org.), 2013

Medicinas Indígenas e as Políticas da Tradição: entre discursos oficiais e vozes indígenas

Luciane Ouriques Ferreira, 2013

Transformação e Persistência: antropologia da alimentação e nutrição em uma sociedade indígena amazônica

Maurício Soares Leite, 2007

Demografia dos Povos Indígenas no Brasil

Heloísa Pagliaro, Marta Maria Azevedo

e Ricardo Ventura Santos (orgs.), 2005

Poder, Hierarquia e Reciprocidade: saúde e harmonia entre os Baniwa do Alto Rio Negro

Luiza Garnelo, 2003 
Formato: $21 \times 26 \mathrm{~cm}$

Tipologia: Egyptian505 BT

Papel: offset $90 \mathrm{~g} / \mathrm{m}^{2}$ (miolo) e Cartão Supremo $250 \mathrm{~g} / \mathrm{m}^{2}$ (capa)

CTP, impressão e acabamento: Imo's Gráfica e Editora Ltda.

Rio de Janeiro, novembro de 2018

Não encontrando nossos títulos em livrarias,

contactar a EDITORA FIOCRUZ:

Av. Brasil, 4036, térreo, sala 112 - Manguinhos

21040-361 - Rio de Janeiro, RJ

Tel.: (21) 3882-9039 e 3882-9007

Telefax: (21) 3882-9006

editora@fiocruz.br

www.fiocruz.br/editora 
Os povos indígenas no Brasil constituem minorias étnicas e demográficas que, não obstante, ocupam um espaço proeminente na trajetória histórica e nos ideários sobre a constituição da sociedade brasileira. Infelizmente esse lócus diferenciado não tem sido acompanhado pelo devido respeito às suas particularidades socioculturais no âmbito da implementação das políticas públicas.

A área da saúde é uma arena privilegiada para análises acerca das relações entre universos indígenas e não indígenas. Por transcender áreas do saber específicas, abrangendo teorias e métodos da antropologia, biologia, ecologia, demografia, epidemiologia, história e saúde coletiva, entre outras, constitui um ponto de confluência entre as ciências humanas e biomédicas. Tanto no meio acadêmico como nos serviços, as pesquisas sobre saúde indígena estão em considerável expansão.

Esta coleção publica estudos originais sobre as mais diversas facetas do processo saúde-doença dos povos indígenas, reunindo obras de autores nacionais e estrangeiros. Seus títulos são uma contribuição para a construção de enfoques teóricos inovadores que, no tocante à saúde, possibilitem estabelecer relações socialmente mais justas entre a sociedade nacional brasileira e os povos indígenas. 